V era C ristina Q ueiroz

\title{
CURSO EM AMBIENTE VIRTUAL DE APRENDIZAGEM: CANTEIRO PARA GERMINAÇÃO DE COMUNIDADE DE APRENDIZAGEM ON-LINE
}

Tese apresentada à banca examinadora da Faculdade de Educação da Universidade de São Paulo, para obtenção do Título de Doutor em Educação (área de Didática, Teorias de Ensino e Práticas Escolares), sob orientação da Prof ${ }^{a}$. Dr ${ }^{a}$. Heloísa Dupas Penteado.

São Paulo 
UNIVERSIDADE DE SÃO PAULO

FACULDADE DE EDUCAÇÃO

V era C ristina Q ueiroz

CURSO EM AMBIENTE VIRTUAL DE APRENDIZAGEM: CANTEIRO PARA GERMINAÇÃO DE COMUNIDADE DE APRENDIZAGEM $O N$ LINE

São Paulo

2005 
V era C ristina Q ueiroz

\section{CURSO EM AMBIENTE VIRTUAL DE APRENDIZAGEM: CANTEIRO PARA GERMINAÇÃO DE COMUNIDADE DE APRENDIZAGEM ON-LINE}

Tese apresentada à banca examinadora da Faculdade de Educação da Universidade de São Paulo, para obtenção do Título de Doutor em Educação (área de Didática, Teorias de Ensino e Práticas Escolares). 
Aos meus queridos pais

$$
\text { José }
$$

e

G abriela (in memoriam) 


\section{AGRADECIMENTOS}

Esta tese de doutorado foi realizada graças à colaboração direta ou indireta de muitos a quem gostaria de expressar os meus mais sinceros agradecimentos:

à Heloísa Dupas Penteado pela paciência, amizade e dedicação com que orientou esta tese de doutorado;

aos professores Vani Moreira Kenski, Romero Tori, Marcelo Giordan, Leland Emerson McCleary, José Manuel Moran Costas e Fredric M. Litto pelo estímulo, compreensão e compartilhamento de conhecimentos;

à CAPES pela concessão da bolsa;

Internet $(E F I)$;

a David Winet que me convidou para fazer parte do grupo English for

aos meus alunos virtuais, sem os quais este trabalho de pesquisa não poderia ser elaborado;

aos colegas e pesquisadores nacionais e internacionais com quem mantive contatos virtuais e com os quais busquei conhecimentos sobre minha temática de estudo;

aos meus amigos que sempre estiveram me apoiando em minha caminhada pessoal e profissional;

transmitir;

aos meus irmãos pelo carinho e compreensão que sempre conseguiram me

aos meus pais pelo amor, entusiasmo e total incentivo que me deram para a concretização desta pesquisa. 
"Quando falo em conquista, quero dizer a conquista duma situação decente para todas as criaturas humanas, a conquista da paz digna, através do espírito de cooperação." (Érico Veríssimo, Olhai os Lírios do Campo). 


\section{RE SU M 0}

A presente pesquisa configura-se como um estudo de caso de natureza qualitativa que procurou analisar e tecer algumas considerações importantes a respeito de um curso livre experimental de inglês básico on-line, denominado Beginner Grammar Writing $(B G W)$, com enfoque no desenvolvimento das habilidades de leitura e de escrita. Esse curso foi oferecido para alunos de diferentes países, cuja língua materna não é o inglês, e ministrado, concomitantemente, por duas professoras da área, residentes em países distintos. Procurou-se verificar se o curso, que adotou uma metodologia de ensinoaprendizagem colaborativa/comunicacional, veio a se tornar uma comunidade de aprendizagem, a partir das características, apontadas por vários teóricos, e das quais elegemos as seguintes: interesses comuns, empatia, sociabilidade colaborativa e tempo de exposição no grupo. Os dados obtidos foram coletados ao longo do curso em questão, no primeiro momento em que foi oferecido. Esses dados consistem em documentos digitais do curso (tais como e-mail dos alunos, e-mail trocados entre as professoras, registros de participação dos estudantes no fórum e em sessões de chat) e na observação participante da professora/pesquisadora ao longo de todo o curso. $\mathrm{O}$ estudo fundamentou-se nas teorias da comunicação escolar, comunicação on-line, de aprendizagem colaborativa e no referencial teórico a respeito de comunidades virtuais (de aprendizagem). A reflexão sobre os dados recolhidos e a análise efetuada apontaram algumas questões relevantes a respeito de ensino de inglês on-line na perspectiva de uma metodologia de ensino-aprendizagem colaborativo/comunicacional e mostraram que o curso $B G W$ atingiu o objetivo de promover 
a aprendizagem coletiva. A análise de dados confirmou ainda que uma comunidade de aprendizagem foi criada e é mantida como tal a partir do curso $B G W$ aqui estudado.

Palavras-chave: comunidade de aprendizagem colaborativa/comunicacional; ambiente virtual de aprendizagem; metodologia colaborativa/comunicacional on-line; curso experimental de inglês online; curso básico on-line de língua estrangeira. 


\section{A BSTRA CT}

The present study is a qualitative case study of an experimental English basic online course, entitled Beginner Grammar Writing $(B G W)$, with emphasis on the development of writing and reading skills. This course was offered to students from different countries, whose native language was not English, and was delivered simultaneously by two teachers of English, resident in distinct countries. The study attempted to verify whether the students in the course, which adopted a teaching and learning collaborative/communicational methodology, became a learning community from the characteristics described by several theoreticians and from which we selected the following: common interests, empathy, collaborative sociability and time of exposure in the group. The data were collected from the course when it was first offered. Data consisted of digital documents (such as students' e-mail, e-mail exchanged between the teachers, questionnaires, registers of students' participation in the discussion forum and in the chat sessions, and some others) and the participative observation of the teacher/researcher throughout the course. The theoretical framework was based on the communicative theory, the collaborative learning approach and the theoretical referential on virtual learning communities. The data showed that the $B G W$ course reached its objective of promoting a collective learning. The data also confirmed that a learning community was created and is maintained as so from the course studied. 
Key words: collaborative/communicational learning community; virtual learning environment; on-line collaborative/communicational methodology; experimental English on-line course; basic on-line EFL course. 


\section{L ista de Q uadros e Figuras}

Quadro 1 - Quadro de Valores

p. 77

Quadro 2 - Características Principais das Ferramentas Descritas

p. 88

Quadro 3 - Aplicações Pedagógicas: Semelhanças e Diferenças entre as Ferramentas

p. 89

Figura 1 - Pastas de Tarefas

p. 116

Figura 2 - External Links

p. 117

Figura 3 - Dicionário On-line

p. 118

Figura 4 - Pastas dos Fóruns de Discussão

p. 119

Figura 5 - Programa de Comunicação de Voz: Wimba

p. 131

Figura 6-E-mail trocados entre as Professoras

p. 133 


\section{L ista de Tabelas}

Tabela 1 - País de Origem dos Alunos

p. 100

Tabela 2 - Grau de Escolaridade

p. 101

Tabela 3 - Área de Estudo

p. 101

Tabela 4 - Habilidade de Uso do Computador

p. 102

Tabela 5 - Conhecimento a respeito dos Cursos do EFI

p. 103

Tabela 6 - Atividades Propostas

p. 136

Tabela 7 - Motivo de Inscrição no Curso On-line

p. 169

Tabela 8 - I Momento do Curso $B G W$

p. 184 


\section{Lista de Siglas}

BGW-Beginner Grammar Writing

CLT - Communicative Language Teaching

EAD - Ensino a distância

EFI - English for Internet

FAQs - Questões mais Freqüentes (do inglês: Frequently Asked Questions)

TICs - Tecnologias de Informação e Comunicação.

UCBEU - União Cultural Brasil-Estados Unidos

URL - Sistema de endereçamento da Web (do inglês: Uniform Resource Locator) 


\section{Sumário}

SEMENTES ou APRESENTAÇÃO

p. 16

I - NUTRIENTES ou FUNDAMENTAÇÃO TEÓRICA

p. 31

1. - Cursos na modalidade on-line e Comunidades virtuais de aprendizagem

p. 31

1.1.- Comunidades virtuais de aprendizagem colaborativa: especificidades para sua formação e manutenção

p. 42

1.2.- Exigências do exercício dos novos papéis de professor e de aluno em cursos on-line

p. 50

1.3.- Curso on-line: visão geral sobre metodologia de ensino-aprendizagem

1.3.1.- Communicative Language Teaching (CLT): uma abordagem

p. 60 metodológica do ensino da língua inglesa

p. 63

2. - Aprendizagem colaborativa

p. 66

2.1.- Conceito de colaboração vs. cooperação

p. 66

2.2.- O significado da aprendizagem colaborativa

p. 70

p. 78

3.1.- Ferramentas de comunicação assíncrona p. 81

3.1.1.- E-mail

p. 81

3.1.2.- Fórum de discussão

3.1.3.- Software de Comunicação de Voz (Wimba Voice Board)

p. 83

p. 85

3.2.- Ferramentas de comunicação síncrona 3.2.1.- Chat

p. 86

p. 86

II - CULTIVO ou METODOLOGIA DA PESQUISA

p. 90

1. - Objeto de pesquisa e tipo

p. 90

2. - Questões de pesquisa e hipótese de trabalho

p. 96

3. - Descrição do contexto de pesquisa

p. 97

3.1.- Os sujeitos

p. 97

3.2.- Cenário (ambiente virtual)

p.103

4. - Coleta de dados

p.104

5. - Tratamento de dados

p.107 
III - COLHEITA ou A EXPERIÊNCIA DA PROPOSTA EXPERIMENTAL ON-LINE

p. 108

A Experiência Vivida

p. 109

1.- Considerações gerais sobre o curso

p.109

2.- Viabilização do curso

p. 113

3.- Conteúdo programático e planejamento

p. 120

A Experiência Interpretada

1.- Curso de inglês on-line na perspectiva de uma metodologia de ensinoaprendizagem colaborativo/comunicacional

p.132

1.1.- Interações colaborativas propostas

p. 133

1.2.- Interações colaborativas realizadas entre as professoras

p. 135

1.3.- Respostas dos alunos às provocações didáticas de natureza colaborativa

p. 140

p.148

1.4.- Aprendizagens discente e docente resultantes

p.154

1.4.1.- Aprendizagens docentes

1.4.2.- Resultados cognitivos de estruturas básicas da língua

p. 154 inglesa

p.161

2.- Formação e manutenção de uma comunidade de aprendizagem

p.168

2.1.- Motivação e interesses comuns

p.168

2.2.- Indícios de relações empáticas

p. 170

2.3.- Comprometimento com o grupo

p.177

2.4.- Tempo de exposição no grupo

p. 183

IV - FRUTOS ou CONSIDERAÇÕES FINAIS

p.188

REFERÊNCIAS BIBLIOGRÁFICAS E WEBGRÁFICAS

p. 195

BIBLIOGRAFIA

p. 203

WEBGRAFIA

p. 208

APÊNDICE A - Questionário inicial

p. 218

APÊNDICE B - Ementa do curso $B G W$

p. 219 
APÊNDICE K - Tecnologia Digital: Plataformas de gerenciamento de cursos na Web - Prometheus e Blackboard 


\title{
Sementes
}

\author{
ou \\ A presentação
}

"Os saberes da vida, os saberes empíricos, mesmo que reconhecidos, utilizados e até ensinados nas aulas, não são geralmente sancionados por títulos e diplomas. (...)" (LÉVY, 2000, p.106).

"Os grandes educadores sempre souberam que aprender não é algo que você faz apenas na sala de aula ou sob a supervisão de professores."

(GATES, 1995, p.231).

As transformações geradas pelo fenômeno da globalização, incrementado pelos recursos tecnológicos da sociedade atual, provocam mudanças significativas no panorama econômico, social, fillosófico, político e cultural. Essas mudanças também impõem uma reestruturação no processo educacional de formação do indivíduo para as novas exigências do mercado de trabalho (atuação em equipes e constante atualização do conhecimento, entre outros) e para o desempenho de atitudes democráticas de cidadania participativa.

Os modelos de educação e o de sociedade estão intrinsecamente relacionados e mantêm entre si uma relação dialética, ou seja, interferem-se. A passagem da sociedade industrial para a sociedade tecnológica traz consequiências para o comportamento do ser humano, o que pode ser exemplificado com as palavras de Morin (2000, p. 76): "Precisamos doravante aprender a ser, viver, dividir e comunicar como humanos do planeta Terra, não mais somente pertencer a uma cultura, mas também ser terrenos”. 
Castells (2003, p. 109) nos adverte que: "Por causa da flexibilidade e do poder de comunicação da Internet, a interação social on-line desempenha crescente papel na organização social como um todo.”

$\mathrm{Na}$ educação, de modo geral, já há também indícios que apontam para um momento de transição do modelo tradicional - centrado no professor-, para o colaborativo / comunicacional - centrado na interação entre professor /aluno /aluno / conhecimento. Esse modelo tem suas bases teóricas no construtivismo (PIAGET; VYGOTSKY estudiosos/referência dessa corrente na psicologia) que parte do princípio de que as trocas de saberes entre os indivíduos são decisivas para o desenvolvimento intelectual do ser humano.

Em um mundo onde o rápido e contínuo desenvolvimento das redes de computadores, e em especial da Internet, abre um amplo leque de mecanismos para incentivar e facilitar o intercâmbio e a interação entre os seres humanos - até mesmo entre aqueles que se encontram geograficamente distantes e são oriundos de diferentes culturas-, faz-se necessário refletir sobre como utilizar esses mecanismos no ensino, de maneira a contribuir para o melhor desenvolvimento possível das potencialidades do ser humano.

Com o advento das tecnologias de informação e comunicação (TICs), defrontamonos com novas possibilidades e desafios no processo de ensino-aprendizagem. Projetos pedagógicos participativos interculturais estão cada vez mais sendo desenvolvidos. Também ambientes virtuais ${ }^{1}$ - para implementação e oferecimento de cursos on-line - estão sendo cada vez mais estudados e utilizados sistemática e progressivamente, à medida que

\footnotetext{
${ }^{1}$ Ambientes virtuais são 'espaços' virtuais, onde usuários conectados à rede podem se organizar em grupos, interagir entre si e trocar informações, através de uma modalidade de comunicação mediada por computador. Exemplos de 'espaços virtuais': salas de bate-papo (chats), quadro de mensagens (message board), Moos (acrônimo para Multi-oriented objects, espécie de chat que possibilita a usuários conectados ao programa via Internet a interação com outros usuários ou com objetos do $\mathrm{MOO}$ ) e sistemas gerenciadores de cursos na Web (como Blackboard, Prometheus, WebCT), entre outros.
} 
através do uso da tecnologia, professores e alunos passam a se conectar via rede, não precisando se limitar ao ambiente das salas de aula tradicionais.

A utilização dos recursos tecnológicos, isto é, da rede de comunicações on-line, possibilita ampliar os espaços físico e temporal compreendidos pela sala de aula.

O acesso a Internet expande e enriquece o escopo educacional por permitir acessar uma vasta gama de informações (BEHRENS, 2000; MASETTO, 2000; ULINE, 1996, entre tantos outros); socializar materiais didáticos ${ }^{2}$, tornando-os disponíveis na Web a um grande número de pessoas; expor nossas idéias, ideologias, opiniões, e nos comunicar com pessoas do mundo todo, ultrapassando limites geográficos e temporais, e dissipando diferenças socioculturais e econômicas. Além disso, permite acesso a profissionais de áreas correlatas e afins ou de outras áreas de estudo/conhecimento para troca de informações, compartilhamento e/ou aquisição de novos saberes.

Apesar do grande potencial de recursos educacionais apresentados pela Internet, persiste o desafio de se estabelecer uma proposta educacional que estimule práticas colaborativas/participativas em que professores e alunos aprendam juntos, ainda que fisicamente separados por questões espaço-temporais. É uma nova forma de pensar a educação para tentar torná-la mais produtiva e capaz de dar conta do ensinar e aprender em ambientes virtuais. Esses ambientes se tornariam 'espaços' de desenvolvimento da capacidade não só cognitiva, mas também afetiva, de relacionamento, de sociabilidade e de colaboração entre educador e educandos e destes últimos entre si.

Duas experiências on-line distintas nas quais tomei parte no ano de 1997 contribuíram para minhas reflexões preliminares a respeito do ensino-aprendizagem

\footnotetext{
${ }^{2}$ Exemplos desta prática de socialização de material didático de inglês podem ser vistos, consultando sites tais como 〈http://www.vemconcursos.com/〉, 〈http://iteslj.org/quizzes/vm.html > e $<$ http://www.studygs.net $>$ onde atuo como contribuinte-voluntária.
} 
mediados por computador. A primeira delas foi a de participação de um projeto piloto intercultural $^{3}$, realizado entre um grupo de alunos brasileiros de um centro de idiomas ${ }^{4}$, União Cultural Brasil - Estados Unidos (UCBEU), com sede em São Paulo, Capital, e um grupo de jovens coreanos da Universidade de Postech, Coréia do Sul, tendo o inglês como língua comum.

A motivação inicial na participação desse projeto se deu pelo fato de, na época, eu ser responsável pelo Computer $L a b^{5}$ da União Cultural, e ter interesse em fazer uso das TICs no ensino e aprendizagem de língua estrangeira.

Esta primeira experiência intercultural teve como objetivos: 1- verificar o grau de adesão a uma proposta de atividade educativa on-line por estudantes de um curso estruturado e presencial (como o da UCBEU);

2- a ocorrência de envolvimento e as expectativas geradas, por um projeto deste tipo, entre alunos de países que não falam a língua inglesa.

Embora os resultados tenham sido favoráveis, desde o primeiro momento de sua realização, já se esboçou uma certeza: a de que esta não é uma tarefa fácil, se a intenção é

\footnotetext{
${ }^{3}$ A experiência teve duas fases distintas. A primeira fase se estendeu por um mês e a segunda por três meses. Da primeira, relato, sucintamente, os procedimentos seguidos para a avaliação do projeto junto aos alunos. Reproduzo através de um quadro as considerações feitas pelos estudantes e a mim enviadas por e-mail, e organizo esses dados em quadros que ilustram a avaliação geral feita pelos alunos a respeito do projeto, os principais problemas por eles levantados, suas expectativas e sugestões. Para detalhes, consulte $<$ http://www.geocities.com/vcqm/Feedback.html>. A segunda fase gerou um artigo curto intitulado "Report on a Penpal Project, and Tips for Penpal-Project Success", que se encontra publicado em The Internet TESL Journal, Vol. IV, $\mathrm{n}^{\mathrm{o}}$ 1, Jan. 1998. Disponível em http://www.aitech.ac.jp/ iteslj/Techniques/MelloPenpal.html.

${ }^{4}$ Centro de idiomas são instituições particulares de ensino de línguas, tais como UCBEU e Associação Alumni, que oferecem cursos básicos, intermediários, avançados e de aperfeiçoamento em um ou mais idioma(s) estrangeiro(s).

${ }^{5}$ As atividades sob minha responsabilidade, desenvolvidas no Computer Lab, eram de natureza pedagógica, e estritamente ligadas à preparação de material didático em inglês, seleção de software e CD-ROM educacionais e elaboração de atividades concernentes à língua estrangeira.
} 
usar uma metodologia de ensino que leve em consideração a aprendizagem colaborativa ${ }^{6}$. Esta exigirá do professor criar mecanismos para engajar os alunos no processo de aprendizagem colaborativa, o que implica também em adotar, enquanto professor, uma postura de envolvimento com eles. Exigirá também do professor avaliar suas condutas e aprender através da observação de sua prática docente.

A segunda experiência originou-se de um curso de treinamento de professores de inglês on-line, intitulado 'On-line Teacher Training', promovido pelo professor David Winet, da UC Berkeley Extension ${ }^{7}$, coordenador do projeto English for Internet $(E F I)^{8}$, no primeiro semestre de 1997. O objetivo do curso era propiciar, em linhas gerais, reflexões e discussões entre professores sobre cursos de inglês ministrados via Web.

Ao término deste curso, o professor David Winet me convidou para fazer parte de sua equipe de professores voluntários que se dedicam ao ensino da língua inglesa via rede. A princípio, a proposta me pareceu utópica. Entretanto, o desafio que me foi lançado, somado ao meu interesse em pesquisar a utilização da rede mundial de computadores como instrumento de comunicação e troca de experiências entre educador e educandos, como meio de disponibilizar conteúdo educacional, e de testar recursos e estratégias didáticas - que pudessem ajudar os alunos a vivenciarem a sua própria aprendizagem-, serviram de estímulo

\footnotetext{
${ }^{6} \mathrm{O}$ conceito de colaboração e o significado da aprendizagem colaborativa são discutidos em NUTRIENTES (Capítulo I - Fundamentação Teórica) deste trabalho.

${ }^{7}$ Quando o EFI foi implantado, o professor David Winet exercia o cargo de professor de inglês como segunda língua (ESL instructor) no Programa de Língua Inglesa da UC Berkeley Extension.

${ }^{8}$ EFI surgiu em 1994 como um curso de inglês, ministrado pelo professor David Winet, via e-mail. O curso era denominado English by Mail e tinha como objetivo explorar os potenciais de ensino on-line. Não se tratava de uma pesquisa universitária. O professor David Winet acredita que o English by Mail tenha sido o primeiro curso de língua inglesa na Internet. Atualmente, o EFI, coordenado por David Winet, é constituído por um grupo de professores voluntários que ministram aulas de inglês na Internet. Os cursos são divididos por níveis: básico, intermediário, avançado, entre outros. Cada curso é ministrado por um professor voluntário. Maiores informações sobre o EFI podem ser obtidas no endereço <http://www.study.com>.
} 
para minha adesão ao grupo EFI como professora voluntária do curso básico de inglês online a falantes de outras línguas.

Minha primeira experiência, ministrando um curso de inglês na modalidade on-line, teve início em setembro de 1997 e durou aproximadamente três meses. O curso intitulava-se Beginner Grammar Writing 5 (BGW5) e era destinado a falantes nativos de vários idiomas. Meu grupo era composto de 15 alunos, todos adultos, oriundos de países tais como México, Índia, Japão, Colômbia, China e Hungria.

A formação desse grupo se deu a partir de uma lista ${ }^{9}$, a mim enviada via $e$-mail pelo professor David Winet, com os nomes e e-mails de alunos de nível básico (principiantes no idioma).

O objetivo do meu curso era dar condições aos alunos de nível básico de desenvolver as habilidades de leitura e escrita, a partir de tarefas que envolviam explicações (simplificadas) e exercícios relativos às estruturas gramaticais e lexicais; atividades de expansão vocabular; leituras de artigos curtos (geralmente encontrados na Web e por mim pré-selecionados), e a elaboração de pequenos parágrafos ${ }^{10}$.

Vale ressaltar que tendo sido esta minha primeira tentativa em ministrar um curso na modalidade on-line, os princípios e métodos adotados não tinham embasamento teórico e a didática adotada no curso foi fruto de minha intuição, vivência e prática profissional no

\footnotetext{
${ }^{9}$ Essa lista, até aproximadamente o ano de 2001, era feita a partir do resultado de um teste de múltipla escolha ao qual os alunos se submetiam para verificação do nível de proficiência na língua inglesa. Em seguida, era distribuída, via e-mail, pelo professor David Winet, aos professores voluntários do grupo EFI (no qual seus cursos estavam inseridos) de acordo com o nível (básico, intermediário, avançado, por exemplo) que o professor se prontificava a ministrar.

${ }^{10}$ O objetivo, estabelecido para meu primeiro curso de inglês básico on-line em setembro de 1997, permanece o mesmo para os demais cursos que venho oferecendo via Web através do EFI desde então para alunos de nível básico.
} 
ensino de inglês como língua estrangeira ${ }^{11}$. Portanto, essa experiência configurou-se como um estudo inicial exploratório, o que afastou qualquer pretensão de análises conclusivas. Entretanto, foi esse ensaio, que me motivou a refletir e me aprofundar nos estudos sobre elaboração, implementação, desenvolvimento e oferecimento de cursos de inglês básico na modalidade on-line. Também, me incentivou a continuar minha busca por meios que me permitam entender quais são os mecanismos que contribuem para a formação, desenvolvimento e a manutenção de comunidades virtuais de aprendizagem colaborativa. Indagava-me se cursos on-line e comunidades virtuais de aprendizagem têm algo em comum.

Minha experiência até o presente momento com cursos livres de inglês on-line põe em evidência a dificuldade de tornar a metodologia de ensino-aprendizagem colaborativa, motivadora, atraente e significativa para os alunos. Fato este comprovado pelo número restrito de indivíduos que se "comprometem" aqueles que, de fato, se predispõem a participar das atividades propostas pelo docente, de interagir e compartilhar conhecimentos com o grupo e de participar ativamente em cursos online.

No entanto a aprendizagem colaborativa é aquela que, dentre as teorias de ensino hoje consideradas, apresenta a oportunidade de desenvolver um trabalho educativo, em que o aprendiz é considerado e atua como sujeito de seu aprendizado, ganhando assim autonomia intelectual e desenvolvendo habilidades sócio-psicológicas favorecedoras da aquisição/construção do conhecimento, que, sabemos, é um produto histórico-social. Enquanto tal, traz em si as marcas das relações sociais que o geraram.

\footnotetext{
${ }^{11}$ Minha atuação e desenvolvimento profissional se deram, ao longo dos anos, principalmente, em centros de idiomas, tais como Associação Alumni e União Cultural Brasil-Estados Unidos-, que difundem a cultura e a língua inglesa.

12 A questão que envolve a participação efetiva dos alunos em meu curso on-line é apresentada em COLHEITA (Capítulo III) da pesquisa.
} 
Portanto, estimular e conseguir a participação dos alunos e seu envolvimento em um curso na modalidade on-line, norteado por uma metodologia de ensino-aprendizagem colaborativo/comunicacional, põe em destaque o papel de um novo professor, que deve estar atento às peculiaridades e singularidades dessa modalidade de ensino.

Segundo Azevêdo (1999), o problema de passividade do aluno é fruto do modelo pedagógico no qual os discentes foram adaptados desde a pré-escola. Nesse modelo, de acordo com o autor, "o aluno é visto fundamentalmente como um receptor de conteúdos, cuja tarefa é assimilar e reproduzir, mas quase nunca problematizar, analisar, refletir, isto é, discutir."

Para além do que considera Azevêdo, acredito ser necessário destacar as características dos tipos de interação pessoal e social entre: (a) educador e educandos (em uma metodologia de ensino-aprendizagem colaborativo/comunicacional); (b) dos educandos entre si, e (c) dos educandos com o conhecimento historicamente acumulado e universalmente valorizado.

Grande número de professores e alunos ainda não está acostumado a dialogar, imersos que se encontram nos ambientes tradicionais de aula. A interação existente entre educador e educandos ainda se dá de modo autoritário e hierárquico, ou seja, o professor ditando, em grande parte, as normas a serem seguidas. Esse tipo de modelo pedagógico, apesar de já enfrentar um generalizado descontentamento docente e discente gerou alunos acomodados e reprodutivos.

Em vista disto, verifica-se a dificuldade que os educandos apresentam em trabalhar juntos, em dialogar/interagir uns com os outros e em 'dialogar' com o conhecimento e informações que podem acessar em diferentes fontes, mesmo nos casos em que o educador utiliza uma metodologia de ensino-aprendizagem colaborativo/comunicacional. 
Neste cenário, são perguntas provocativas desta pesquisa ${ }^{13}$ :

$>$ Como sensibilizar os alunos para o valor das trocas de experiências e conhecimentos para a aprendizagem, em culturas em que o valor da competição é estimulado em alta freqüência?

$>$ Como incitar os estudantes para uma relação pessoal mais autêntica e autônoma com o conhecimento?

$>$ Como desenvolver atitudes individuais e coletivas necessárias para otimizar o aprendizado mais participativo, colaborativo e dinâmico em ambientes virtuais?

$>$ Como criar uma "cultura" de interação colaborativa entre professor e aluno e destes últimos entre si?

$>$ É possível que um curso on-line, no qual se consiga fomentar interações, criar e firmar vínculos afetivos e sociais entre indivíduos (que talvez nunca venham a se conhecer/encontrar presencialmente) possa ser um 'degrau' importante para que uma comunidade virtual de aprendizagem $^{14}$ se desenvolva?

Estes questionamentos levam a refletir sobre o desafio que se lança ao professor para engajar a si e a seus alunos em um processo real de ensino-aprendizagem colaborativo, e sobre um curso on-line com aspirações de vir a ser uma comunidade virtual produtiva de aprendizagem, onde haja o compartilhamento do conhecimento e relações sócio-pedagógicas organizadas horizontalmente.

13 As quatro primeiras questões estão vinculadas à abordagem metodológica e atividades escolhidas e aplicadas no curso experimental de inglês on-line por mim ministrado. A última questão diz respeito à possibilidade de formação de uma comunidade virtual de aprendizagem. Estas perguntas são retomadas em CULTIVO (Capítulo II) e discutidas em COLHEITA (Capítulo III).

${ }^{14}$ A discussão a respeito de comunidade virtual de aprendizagem é apresentada em NUTRIENTES (Capítulo I) desta pesquisa. 
Na tentativa de me aproximar de algumas respostas para minhas dúvidas, inquietações e desejos, o presente trabalho tem como objetivo geral verificar se um curso livre de inglês básico on-line pode vir a se configurar como uma comunidade de aprendizagem.

E tem como finalidade específica a elaboração, montagem e execução de uma proposta pedagógica experimental de curso livre de inglês on-line que tem por meta promover o aprendizado básico de língua inglesa, com enfoque no desenvolvimento das habilidades de escrita e leitura, através do ensino-aprendizagem colaborativo. Para tanto, serão trabalhados valores pessoais e sociais - tais como exercício da autonomia, da sociabilidade, da integração social e de respeito mútuo - a fim de se estabelecer um maior grau de envolvimento entre os participantes e com o conhecimento da língua inglesa.

Deve-se ressaltar que a questão fundamental de cursos on-line não está na tecnologia em si, pois esta se apresenta em constante atualização e modificação. Problemas técnicos cujas soluções ainda não estão disponíveis, ou são precárias, podem estar solucionados ou incrementados em um curto espaço de tempo - até mais curto do que o tempo disponibilizado para a construção de uma tese como esta.

Esse mesmo pensamento, de que a tecnologia não ocupa papel principal na implementação e desenvolvimento de um curso on-line, é revelado por Heide e Stilborne (2000, p. 23) quando afirmam que “o valor da tecnologia na educação é derivado inteiramente de sua aplicação”. De forma complementar, Lévy (1999) esclarece que a tecnologia, per se, não é nem boa, nem má. Tudo depende do uso que dela se faz.

Kozma (1991), por outro lado, afirma que o meio, em conjunto com o método utilizado, influenciam na forma pela qual o aprendiz representa e processa as informações. 
A partir dos posicionamentos desses autores sobre a tecnologia, ressalta que o fundamental é fazer uma reflexão crítica sobre a escolha da mídia digital a ser utilizada (suas limitações e potencialidades) e que esta seja vinculada à elaboração do planejamento do curso.

A escolha de uma plataforma de gerenciamento de cursos on-line ${ }^{15}$ e das ferramentas por ela oferecida deve ser feita, tendo em vista as propostas pedagógicas do curso a ser realizado on-line, do perfil, das necessidades e expectativas dos alunos. Sendo assim, o que é relevante de fato para o educador é valorizar a tecnologia como um canal de comunicação e não como um fim. O que importa são as formas de utilização das ferramentas e da tecnologia e o modo como se relacionam/interagem, entre si e com o conhecimento, que está sendo trabalhado à distância, aqueles que dela fazem uso.

O problema, em si, é complexo tanto em situações de ensino on-line quanto presencial, pois incide sobre o comportamento humano, a relação entre pessoas que agem movidas por sentimentos, desejos, convicções e interesses. Essa complexidade aumenta se envolve indivíduos de diferentes culturas, com idéias, conceitos e formações diversificadas.

Em situações de ensino não presencial verifica-se também como elemento complicador o fato de as relações entre pessoas serem "descorporificadas", ou seja, destituídas de seus corpos - canal de expressão complementar nas relações sociais presenciais -, cujo papel, significado e extensão não se encontram suficientemente delineados e, cujo esclarecimento maior, talvez venha mesmo a resultar do enfoque de relações estabelecidas on-line.

\footnotetext{
${ }^{15}$ Plataforma de gerenciamento de cursos on-line é um software que integra, em um único sistema, ferramentas disponibilizadas na Web (fórum, chat, e-mail, por exemplo). Outras características da plataforma são: a disponibilização de diversas estatísticas sobre o curso e sobre os alunos (número de acessos e áreas do programa mais utilizadas pelos usuários, por exemplo), ferramentas administrativas (planejamento), ferramentas de trocas e armazenamento de arquivos, de comunicação e de criação de testes de avaliação, facilitando assim a organização e gerenciamento de um curso.
} 
É importante, então, que o educador reflita sobre os aspectos relativos à interação humana em situações gerais e os aspectos relativos à interação educativa, em situações de ensino. Neste último caso, é preciso que ele esteja atento à experiência docente no seu próprio decorrer e à observação do que nelas ocorrem.

Busca-se através desta pesquisa colaborar com a criação de uma 'cultura' não autoritária ou impositiva, mas uma 'cultura' participativa, colaborativa, de confiabilidade e de comprometimento entre os membros do grupo - alunos e professores on-line. E para que isso possa ocorrer, cabe a recomendação de Moran (2000, p. 16):

[...] somente podemos educar para a autonomia, para a líberdade com processos fundamentalmente participativos, interativos, libertadores, que respeitem as diferenças, que incentivem, que apóiem, orientados por pessoas e organizações livres.

Em outro texto, do mesmo autor, encontrado na Internet ${ }^{16}$, destaca-se a relevância para o professor de ser livre ${ }^{17}$, aberto a mudanças na educação e na sociedade. Afirma Moran que:

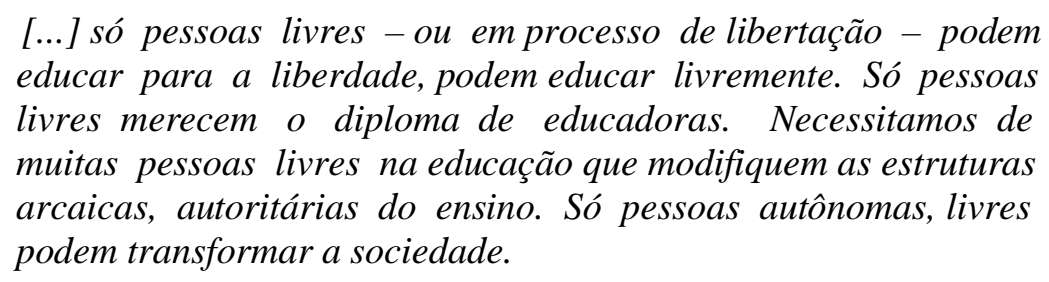

Nessa perspectiva, a primeira condição para um processo de mudança - de busca por novas formas de ensinar e aprender, com ou sem tecnologias avançadas -, requer um professor que almeje a liberdade, alguém que não tema romper as regras pré-estabelecidas e ultrapassadas, e as pressões burocráticas e institucionais, que cerceiam a manifestação da

\footnotetext{
${ }^{16}$ MORAN, J. M. Educar o educador, [199-]. Disponível em: 〈http://www.eca.usp.br/prof/moran/educar.htm>. Acesso em: 28/04/2002.

${ }^{17}$ Esse mesmo aspecto é destacado pelo médico psiquiatra e consultor organizacional Roberto Shinyashiki: "Quando se é livre e espontâneo, o universo passa a ser um grande jardim onde podem desabrochar suas flores, lágrimas, talentos e idéias. Viver com autonomia é produzir a seiva da própria vida." SHINYASHIKI, R. Sem Medo de Vencer. São Paulo: Editora Gente, 1993, p.90.
} 
autonomia e da liberdade docente. Esse será o educador que poderá melhor contribuir para a formação de indivíduos autônomos, verdadeiros cidadãos - criativos e críticos -, quesitos sem os quais a vida e a participação no mundo contemporâneo ficam prejudicadas.

E no caso específico do uso de tecnologias digitais no ensino, Moran (2000, p. 63) adverte que:

\begin{abstract}
Ensinar com as novas mídias será uma revolução se mudarmos simultaneamente os paradigmas convencionais do ensino, que mantêm distantes professores e alunos. Caso contrário, conseguiremos dar um verniz de modernidade, sem mexer no essencial.
\end{abstract}

Para que reais mudanças possam ocorrer, pois, são necessárias: a reestruturação na prática de ensino e reformas nos sistemas educacionais vigentes, principalmente das instituições que oferecem cursos de formação de professores, bem como considerar a possibilidade do ensino não institucionalizado, aberto pelo ciberespaço ${ }^{18}$ (LÉVY, 1999).

No que diz respeito ao futuro dos sistemas de educação e de formação no ciberespaço, Lévy (1999) aponta para o fato deste estar vinculado à “uma análise prévia da mutação contemporânea da relação com o saber”. O autor também destaca a importância "de orientar os percursos individuais no saber" e o reconhecimento das experiências adquiridas pelos indivíduos ao longo da vida. E ainda chama atenção para o fato de que “uma vez que os indivíduos aprendem cada vez mais fora do sistema acadêmico, cabe aos sistemas de educação implementar procedimentos de reconhecimento dos saberes e savoirfaire [grifo do autor] adquiridos na vida social e profissional.” (p. 175).

As considerações de Lévy espelham a demanda que se verifica hoje por cursos menos rígidos e uniformes, uma vez que aqueles já não correspondem às atuais exigências

\footnotetext{
${ }^{18}$ O termo Ciberespaço, originário do romance de ficção científica Neuromancer (1984) de William Gibson, é o nome dado para o espaço não físico ou territorial, composto de redes de computadores interligados, onde palavras, relacionamentos humanos, dados, riqueza e poder são manifestados das mais diversas formas.

Lévy (1999, p. 92) define ciberespaço como "espaço de comunicação aberto pela interconexão mundial dos computadores e das memórias dos computadores."
} 
e especificidades do mercado de trabalho da contemporaneidade, ou da vida dos cidadãos. Ao mesmo tempo em que põe em destaque a questão da liberdade e da pessoa do educador.

Em se tratando de ensino na modalidade on-line, é fundamental uma reflexão sobre a atuação de professores e alunos capazes de trabalhar e estudar on-line. Essa reflexão possibilita o desenvolvimento de cursos de qualidade nesta modalidade que possam preencher as expectativas e necessidades de uma nova proposta educacional.

Como pondera Morin (2000, p. 61):

$$
\begin{aligned}
& \text { [...] uma das vocações essenciais da educação do futuro será } \\
& \text { o exame e o estudo da complexidade humana. Conduziria à toma- } \\
& \text { da de conhecimento, por conseguinte, de consciência, da condição } \\
& \text { humana comum a todos os humanos e da muito rica e necessária } \\
& \text { diversidade dos indivíduos, dos povos, das culturas, sobre nosso } \\
& \text { enraizamento como cidadãos da Terra. }
\end{aligned}
$$

Espera-se que os resultados desta pesquisa possam vir a ser relevantes para colaborar com futuros estudos e trabalhos pedagógicos inovadores e significativos para o ensino na modalidade on-line e sobre comunidades virtuais de aprendizagem colaborativa.

Para dar conta do trabalho, que aqui me proponho, optei por organizar capítulos nomeados por temas metafóricos relacionados ao plantio, que ilustram as fases desta pesquisa. Assim, em SEMENTES com uma breve indicação de experiências que geraram esta pesquisa, procedo a apresentação da tese.

Em NUTRIENTES (Capítulo I) organizo a fundamentação teórica em que me apóio. Este capítulo subdivide-se em três itens fundamentais com seus sub-itens correspondentes: Cursos na modalidade on-line e Comunidades virtuais de aprendizagem, Aprendizagem Colaborativa, e Ferramentas digitais: usos pedagógicos. 
Em CULTIVO (Capítulo II) trato da metodologia da pesquisa. O capítulo apresenta a opção metodológica em face das metas pretendidas, descreve o contexto de pesquisa, e indica como os dados foram coletados e analisados.

Em COLHEITA (Capítulo III) tem-se o acompanhamento da proposta experimental on-line. Este capítulo contém dois itens: A Experiência Vivida e A Experiência Interpretada. No primeiro item, discorro sobre o curso em seu primeiro momento de efetivação. No segundo item, é feita a análise dos dados coletados.

Em FRUTOS (Capítulo IV) são apresentadas as contribuições para uma didática colaborativa no ensino on-line e, especificamente, no ensino on-line de inglês como língua estrangeira, e sugestões de investigações decorrentes deste estudo.

Seguem-se as Referências Bibliográficas e Webgráficas, Bibliografia e Webgrafia que serviram de base para o estudo.

Finalmente, os Apêndices que deram suporte à realização dos estudos preliminares e constituem o ponto de partida desta pesquisa. 


\section{Capítulo I - N utrientes}

\section{ou \\ F undamentação T eórica}

“[...] O verdadeiro poder das comunidades - quer na ou fora da Web - recai no seu poder de afetar a vida física, emocional, espiritual, e profissional das pessoas de forma significativa." (KIM, 2000, p.352). ${ }^{19}$

1.- C ursos na modalidade on-line e comunidades virtuais de aprendizagem.

Com o aumento da popularidade da Internet está havendo um impacto nas formas como as pessoas interagem no ciberespaço e uma variação nos modos pelos quais conceituam o termo "comunidade" (BROWN, R. E., 2001; CASTELLS, 2003; KIM, 2000; LÉVY, 1998a, 1999; PALLOFF \& PRATT, 1999; RHEINGOLD, 1993; SILVIO, 1999, entre tantos outros).

A idéia de comunidade virtual nos remete primeiramente a Rheingold (1993), um especialista no assunto. Para o autor, comunidades virtuais são agregados sociais que surgem na rede quando um grupo de pessoas mantém discussões de natureza pública, com emoção, por um período suficientemente longo, a ponto de formar redes de relações pessoais no ciberespaço.

\footnotetext{
${ }^{19}$ No original: "[...] The true power of communities - whether on or off the web - lies in their power to affect people's physical, emotional, spiritual, and professional lives in a meaningful way." As traduções dos trechos citados nesta pesquisa são todas de minha autoria.
} 
Ao comparar comunidades virtuais com pequenas colônias de microorganismos que proliferam em uma placa de Petri $^{20}$ e a Internet com o ágar-ágar (substância utilizada no cultivo de micro-organismos), Rheingold tenta explicar como as comunidades virtuais se propagam e evoluem. Assim como se nutrem os microorganismos com o ágar-ágar, também se faz necessário "alimentar" as comunidades virtuais para que elas se desenvolvam.

As colocações postas pelo autor me fizeram refletir sobre o significado do professor em cursos on-line que vise desenvolvê-los em comunidades virtuais de aprendizagem e mantê-las como tal.

Em uma tentativa de adaptação das analogias utilizadas por Rheingold à idéia de comunidades virtuais de aprendizagem, creio poder cogitar que o ambiente virtual corresponde à placa de Petri, pois se configura como suporte que permite que o grupo virtual exista. O professor, a princípio, é o aplicador do ágar-ágar que nutre/alimenta o grupo de aprendizes, através de sua mediação pedagógica. Esses aprendizes, em seguida, se tornam também auto-aplicadores do agár-agár, e contribuem para que o grupo possa vir a se constituir em uma comunidade que cresce e prospera.

Palloff \& Pratt (1999), ao tratar da temática, salientam que as tentativas de se comunicar são formas de se constituir uma comunidade. Esses autores ${ }^{21}$ salientam também que muitos estudiosos desse assunto concordam que alguns dos passos básicos para a construção de comunidades on-line são os seguintes:

\footnotetext{
${ }^{20}$ Recipiente para o preparo dos meios de cultura, sendo que o mais utilizado, atualmente, é o de plástico estéril. LARPENT, J.P. \& LARPENT-GOURGAUD, M. Microbiologia prática. Trad. Maria Christina de Mello Amorozo, rev. Elfried E. Kirchner. SP, Edgar Blücher. Ed. da Universidade de São Paulo, 1975.

${ }^{21}$ No original, os passos básicos, apresentados pelos autores, são: "clearly define the purpose of the group; create a distinctive gathering place for the group; promote effective leadership from within; define norms and a clear code of conduct; allow for a range of member roles; allow for and facilitate subgroups; allow members to resolve their own disputes" (p. 24).
} 
Definir claramente o propósito do grupo.

Criar um local distinto para o grupo se encontrar.

Promover uma liderança efetiva dentro do próprio grupo.

Definir normas e um código claro de conduta.

$>$ Possibilitar uma variedade de papéis para os membros do grupo.

Possibilitar e facilitar a criação de subgrupos.

Possibilitar aos membros resolverem suas próprias disputas.

Kim (2000) apresenta estratégias a serem seguidas para se ter comunidades de sucesso bastante semelhantes às citadas por Palloff e Pratt (op. cit.). Acrescenta, entretanto, a autora, mais duas: promover eventos cíclicos (para desenvolver relações mais fortes entre os membros da comunidade) e integrar rituais da vida comunitária.

Segundo Kim, o assunto/ a temática pode ser o "chamariz" que faz com que as pessoas integrem uma comunidade, mas é a relação que se estabelece entre elas que as fazem continuar na comunidade. E acrescenta que é papel de quem quer que inicie uma comunidade de ajudar os membros a estabelecerem e desenvolverem essas relações. ${ }^{22}$

É importante ressaltar ainda que as comunidades se manifestam de formas diferentes e com características variadas (KIM, 2000; LÉVY, 1999; PALLOFF \& PRATT, 1999). A respeito desse assunto, Lévy afirma que as comunidades "parecem ser um excelente meio (entre centenas de outros) para socializar, quer suas finalidades sejam lúdicas, econômicas ou intelectuais, quer seus centros de interesse sejam sérios, frívolos ou escandalosos" (p. 132).

\footnotetext{
${ }^{22}$ No original: "people may come to your community for the content, but they'll stay for the relationship and your job is to help your members establish and develop those relationships" (p.76). As adaptações, por mim feitas para a versão em português, visam tornar as idéias mais claras.
} 
Para Lévy (1998c), a comunidade virtual está associada às afinidades/sentimentos que permeiam a sua organização. Ao tratar desse tema, o autor aborda, principalmente, características que podem ser observadas nessas comunidades: o que une seus membros e as relações sociais que se estabelecem entre eles, ou seja, problemas, conflitos, paixões e amizades. Segundo esse autor:

Uma comunidade virtual pode, por exemplo, organizar-se sobre uma base de afinidade por intermédio de sistemas de comunicação telemáticos. Seus membros estão reunidos pelos mesmos núcleos de interesse, pelos mesmos problemas: a geografia, contingente, não é mais nem um ponto de partida, nem uma coerção. Apesar de "não-presente", essa comunidade está repleta de paixões e de projetos, de conflitos e de amizades. Ela vive em lugar de referência estável: em toda parte onde se encontrem seus membros móveis...ou em parte alguma. A virtualização reinventa uma cultura nômade, não por uma volta ao paleolítico nem às antigas civilizações de pástores, mas fazendo surgir um meio de interações sociais onde as relações se reconfiguram com um mínimo de inércia. (p.20-21)

Embora as relações interpessoais conflitantes, apontadas por Lévy como possíveis de serem geradas em comunidades virtuais, possam, à primeira vista, parecer negativas, elas são apontadas como positivas por Palloff \& Pratt (1999).

Argumentando sobre os conflitos gerados em comunidades virtuais, estes dois últimos autores afirmam que "ele [o conflito] é necessário para se conseguir coesão do grupo e intimidade e questionam por quê tantos o temem e tentam evitá-lo, especialmente nesse meio" (p. 27). ${ }^{23}$ E mais ainda que:

$\mathrm{Na}$ comunidade de aprendizagem on-line, o conflito contribui não apenas para a coesão do grupo, mas para a qualidade dos resultados da aprendizagem. Portanto, os instrutores em um ambiente on-line precisam se sentir confortáveis com o conflito; podem até mesmo precisar iniciá-lo ou facilitar sua resolução. E deveriam aplaudir seu surgimento (p. 28). ${ }^{24}$

\footnotetext{
${ }^{23}$ No original: "[...] it is necessary in order to achieve group cohesiveness and intimacy, why do so many fear it and attempt to avoid it, especially in this medium."

${ }^{24}$ No original: "In the on-line learning community, conflict contributes not only to group cohesion but to the quality of the learning outcome. Therefore, instructors in the on-line environment need to feel comfortable
} 
Como se pode perceber pelas afirmações desses autores, são as resoluções dos conflitos gerados nesses ambientes que promovem, enriquecem e consolidam as relações entre os membros da comunidade virtual.

Outro aspecto importante a ser considerado no presente estudo, apontado por Lemos (2002), é o que contrapõe os conceitos de agregação eletrônica, que ele subdivide em: comunitária e não comunitária. Segundo esse autor, nas primeiras os membros expressam "uma afinidade subjetiva delimitada por uma território [sic] simbólico, cujo compartilhamento de emoções e troca de experiências pessoais são fundamentais para a coesão do grupo". No segundo tipo, não há formação comunitária, pois não existem formas de compartilhamento simbólico e pessoal, e as relações entre os participantes são de natureza efêmera. Diante do exposto e pelas respostas dadas pelo autor ao questionamento que lhe fiz por $e$-mail ${ }^{25}$, verifica-se que nem todo "agrupamento" de indivíduos na Internet pode ser chamado de ou considerado como comunidade virtual.

Com relação à comunidade virtual de aprendizagem, Palloff \& Pratt (1999) apresentam alguns indicadores que marcam sua existência. São eles: ${ }^{26}$

with conflict; they may actually need to trigger it or to assist with the facilitation of its resolution. And they should applaud its appearance."

${ }^{25}$ LEMOS, A. Re: cibercultura [mensagem pessoal]. Mensagem recebida por <vcqm@uol.com.br> em 19 abr. 2002.

No original: > Você diria que a cultura do sentimento é a base para a formação de comunidades virtuais?

Não so das comunidades virtuais mas de qualquer forma comunitário. Sem essa forma de pertencimento não podemos chamar agrupamentos de comunidades.

>Seria ela que estabelece o diferencial entre agregações eletrônicas e comunidades virtuais?

Sim, como ir a um bar. Se chego la, me agrego aos outros mas não formo uma comunidade. Mas se vou a esse mesmo para e encontro sempre meus amigos, onde desenvolvo uma relacao de proximidade e de empatia, entao esse bar e' um locus da minha comunidade. Podemos dizer o mesmo para listas, chats, blogs... $>$ Como você definiria formas coletivas de empatia e qual o impacto delas na formação das comunidades?

E o que falei antes. São formas de compartilhamento territorial (simbolico e fisico). Sem isso não há formacao comunitaria.

${ }^{26}$ No original: "Some of the desired outcomes, then, indicating that an online community has been forming, are as follows: Active interaction involving both course content and personal communication; Collaborative learning evidenced by comments directed primarily student to student rather than student to instructor; Socially constructed meaning evidenced by agreement or questioning, with the intent to achieve agreement on 
Interação ativa envolvendo tanto o conteúdo do curso quanto as comunicações pessoais;

> Aprendizagem colaborativa evidenciada por comentários feitos principalmente entre os estudantes mais do que entre os estudantes e o instrutor;

D Evidência de significado construído socialmente por acordos e questionamentos com o intuito de chegar a acordos sobre problemas de significado;

> Troca de fontes de informação entre os estudantes;

$>$ Expressões de apoio e encorajamento trocadas entre os estudantes, assim como disposição de avaliar criticamente o trabalho de outros.

É interessante observar que os indicadores postos por Lemos (2002) para caracterização da agregação eletrônica de tipo comunitário recaem nas relações pessoais e afetivas entre os membros do grupo. Entretanto, em Palloff \& Pratt (1999), encontram-se explícitas as relações entre os aprendizes, com o instrutor, e com o significado construído socialmente.

Para a formação de comunidade virtual de aprendizagem, Palloff \& Pratt (op.cit.) chamam atenção para o fato de ser crucial dar espaço para episódios da vida cotidiana (fim de um relacionamento, doença na família, entre outros), o que já foi mencionado por Kim (2000) como estratégia para construção de uma comunidade. Tais ocorrências, a meu ver, constituem-se em fortes variáveis interferentes na qualidade do processo de ensino on-line,

issues of meaning; Sharing of resources among students; Expressions of support and encouragement exchanged between students, as well as willingness to critically evaluate the work of others.” (p. 32). 
que se não trabalhadas podem ser até fatais para o bom desenvolvimento da comunidade de aprendizagem.

Silvio (1999), apresenta uma distinção interessante entre comunidades virtuais e comunidades virtuais de aprendizagem. Segundo o autor, "geralmente as CVA [comunidades virtuais de aprendizagem], por serem fortemente focadas, tendem a ser mais estruturadas e fechadas do que as outras comunidades."

De acordo com Laister \& Kober (2002), a usabilidade (interação homemmáquina), a sociabilidade (processos de interação social) e suas inter-relações são vistas como fatores que podem contribuir para o desenvolvimento de comunidades on-line. Além desses fatores, os autores apontam outros, mencionados por Preece (2000), para o sucesso das comunidades de aprendizagem: necessidades adicionais dos alunos e tutores, tais como acesso a recursos na Web, orientação, feedback e prazer (em aprender).

Para Laister \& Kober o grande desafio para criação de comunidades virtuais de aprendizagem está em estabelecer e dar subsídios para uma "nova cultura de aprendizagem", onde a comunicação se dá de forma horizontal e é efetiva entre os indivíduos envolvidos na aprendizagem. A esse contexto acrescentam-se os aspectos sociais da aprendizagem e o comprometimento dos indivíduos com o grupo.

De forma complementar e similar, Wilson (2001) julga que o sentido de comunidade entre os aprendizes se caracteriza por: sentimento de pertencer à comunidade, confiança, expectativa de aprender e comprometimento em participar e contribuir com a comunidade (aspectos também apontados por PALLOFF \& PRATT, 1999; RHEINGOLD, 1993, entre outros).

A partir das asserções dos autores aqui referenciados se estabelecem características peculiares e variáveis importantes para a formação de uma comunidade virtual efetiva. 
Ao tratar da questão de elaboração e implementação de um curso na modalidade on-line, deve-se atentar para o fato de que nem todo curso on-line atinge a configuração de comunidade de aprendizagem, ou se aproxima da formação de uma. Tudo depende da intencionalidade do docente ao criar e oferecer o curso, de suas propostas pedagógicas e do envolvimento que consegue estabelecer entre ele professor e os alunos, destes últimos entre si e com o conhecimento.

Encontro em Hiltz (2004) ${ }^{27}$, em resposta à questão “você diria que nem todos os cursos se transformam em comunidades?", a ela por mim enviada por e-mail, que "é verdade; nem todos os professores têm isso como objetivo. Mas aqueles que querem não estruturam; facilitam e premiam de tal forma a encorajar a emergência da comunidade de aprendizagem”.

Ainda há professores que tentam reproduzir no ambiente digital o modelo de ensino, concebido para a sala de aula tradicional, ou seja, o foco é dado primordialmente à informação e ao conteúdo; a comunicação se dá de forma bidirecional entre professor e o aprendiz, ou entre este último e o tutor/monitor do curso $^{28}$, que se encarrega de responder as dúvidas dos alunos e orientá-los, quando necessário, no desenvolvimento das atividades da disciplina.

Almeida (2003), citando Prado e Valente (2002), afirma que quando se transferem para o meio virtual os mesmos paradigmas da sala de aula presencial tem-se o que eles denominam a "virtualização da sala de aula".

\footnotetext{
${ }^{27}$ HITZ, R. Re: Fwd: sense of community in online courses (new attempt/ms bounced back) [mensagem pessoal]. Mensagem recebida por <vcqm@uol.com.br> em 02 abr. 2004.

No original: [...] > So would you say that not all courses evolve to communities?

yes that is true; not all teachers even have this as a goal. But some who want to, do not struture and facilitate and reward in such a way as to strongly encourage the emergence of a learning community.

${ }^{28} \mathrm{O}$ termo tutor/monitor aqui empregado diz respeito ao indivíduo, com responsabilidades pedagógicas, sociais e até técnicas, selecionado pelo professor efetivo para auxiliá-lo no desenvolvimento das atividades da disciplina.
} 
Nesse tipo de modelo, a interação de aprendizagem entre os alunos não é potencializada e, portanto, o curso não se configura como comunidade de aprendizagem.

Kerckhove $^{29}$, respondendo $e$-mail desta pesquisadora afirma que:

"Um curso on-line só pode ser definido como uma comunidade se houver interação entre os estudantes, e não apenas entre o professor e um membro do grupo individualmente. Comunidades podem e se transformam a partir de cursos on-line. [...]"

Por outro lado, quando o curso on-line prioriza a interação entre os sujeitos envolvidos no ensino-aprendizagem (professor/aluno/aluno) é possibilitada a formação de uma comunidade de aprendizagem (HILTZ, 2004; KERCKHOVE, 2004; LYMAN, 2004; REID, 2004; RHEINGOLD, 2004) ${ }^{30}$, onde o processo de aquisição do conhecimento se faz de forma compartilhada entre todos os seus membros. Corrobora para tanto uma proposta metodológica orientada para o ensino-aprendizagem colaborativo. Além disso, quando o sentido de comunidade virtual de aprendizagem é valorizado, os alunos geralmente se sentem mais satisfeitos e suas experiências de aprendizado são ampliadas e aperfeiçoadas $(\mathrm{TU}, 2004)^{31}$.

Ressalta-se, entretanto, que essa comunidade pode desaparecer quando o curso é concluído e outra se formar com novos alunos quando o curso é novamente oferecido (SILVIO, 1999). Ou ainda, conforme Kenski (2001, p. 53), “a comunidade específica de

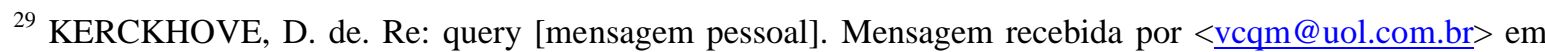
11 mar. 2004. No original: "An on-lie course can only be defined as a community is there is interaction among the students, and not only between the teacher and individual members. Communities can and do evolve from on-line courses, but it is always improved by ongoing or subsequent F2F meetings...Cheers. ddek".

30 Afirmação baseada em respostas dadas por Lyman (30/03/2004), Kerckhove (11/03/2004), Rheingold (24/03/2004), Hiltz (02/04/2004) e Reid (01/05/2004) às questões por mim formuladas sobre cursos on-line e comunidades virtuais de aprendizagem e a eles enviadas via $e$-mail.

${ }^{31}$ TU, Chih-Hsiung. Re: FW: query [mensagem pessoal]. Mensagem recebida por 〈vcqm@ uol.com.br> em 22 abr. 2004. No original: Hi Vera,

Dr. McIsaac has forwarded your e-mail to me. 〈snip>

"Online learning community is critical concept in online learning since it has potential to enhance online learning quality. Some courses may not value the importance of online learning community but with higher degree of sense of online learning community, students generally are more satisfied and their learning experiences are enhanced and improved." 
‘aprendizagem' vai além do tempo de uma disciplina ou curso” e mais “as comunidades de aprendizagem ultrapassam as temporalidades regimentais estabelecidas pela cultura educacional”, estabelecidos e mantidos os fatores que possibilitam a formação da comunidade.

Uma diferença básica e fundamental entre um curso on-line e uma comunidade está no fato de que um curso supõe um professor e uma comunidade não. Tem-se, então, em um curso, já a priori, uma diferenciação marcada entre os papéis de seus componentes: o professor e os alunos ${ }^{32}$.

Outro aspecto divergente entre curso e comunidade está vinculado à idéia de que comunidade implica em vínculos de sentimento (bonds of sentiment - FEENBERG, 1989), o que nem sempre ocorre em um curso on-line.

Entre os propósitos de formação de uma comunidade, Brown, R. E. (2001) enfatiza encorajar a comunicação continuada após o término de um curso ou programa. Inclui a autora que isso tem como objetivo a prestação de serviços à carreira, promovendo o desenvolvimento profissional continuado, quesito fundamental da sociedade contemporânea.

Baseada em minha experiência em cursos livres on-line e na literatura referente a essa temática, entendo que são os vínculos afetivos e sociais, estabelecidos entre os integrantes do grupo, que permitem extrapolar os limites formais de um curso e gerar a possibilidade de desenvolvimento da comunidade de aprendizagem, que desse modo pode se manter agregada pelos interesses comuns iniciais que levaram os alunos a ingressarem em um dado curso.

\footnotetext{
${ }^{32}$ Esse assunto é retomado e ampliado na página 71 deste capítulo.
} 
Levando em consideração as questões apresentadas e apoiada em Lyman (2004) ${ }^{33}$, discordo de Azevêdo (1999) quando o autor afirma que "uma das coisas que logo se evidencia ao se passar para ambientes virtuais é que turmas virtuais são comunidades virtuais de aprendizagem colaborativa”. Isso pode ou não ocorrer, dependendo de os membros do grupo (os alunos) desenvolverem ou não relações de confiança e de reciprocidade e se houver entre eles forte motivação e interesses comuns.

Após este percurso teórico, entendo que um curso na modalidade on-line, que vise se identificar e/ou a se transformar em uma comunidade virtual de aprendizagem necessita, acima de tudo, priorizar os laços afetivos (FEENBERG, 1989; LÉVY, 1998c; RHEINGOLD, 1993) e sociais (KIM, 2000; LAISTER \& KOBER, 2002; LÉVY, 1998c; PALLOFF \& PRATT, 1999) que se estabelecem; aprender a conviver com a diversidade (lingüística e cultural - LEFFA, 2001) e a singularidade (ALMEIDA, 2003); analisar as formas pelas quais o grupo interage (HILTZ, 2004; KENSKI, 2001; KERCKHOVE, 2004; LYMAN, 2004; REID, 2004; RHEINGOLD, 2004), a princípio mediadas pelo professor e, a posteriori, estimuladas por todos os membros do grupo; compartilhar experiências, vivências, conhecimentos e resoluções de problemas (PALLOFF \& PRATT, 1999; WILSON, 2001); valorizar e aceitar que decisões/atuações conjuntas de professor e alunos sejam trabalhadas no processo de ensino-aprendizagem (PENTEADO, 2002).

\footnotetext{
${ }^{33}$ LYMAN, P. Re: Fwd: query (new attempt/ms bounced back) [mensagem pessoal]. Mensagem recebida por <vcqm@uol.com.br> em 30 mar. 2004. No original: >Would you say that an online course is a community? If so, why?

"It might be, if people develop trusting and reciprocal relationships. I think this works best if people have met face to face to develop a sense of individual and collective identity, but it is possible to develop these feelings online if people have strong motivations and similar interests.[...]"
} 
1.1.- Comunidades virtuais de aprendizagem colaborativa: especificidades para sua formação e manutenção.

Para a formação, o desenvolvimento e, principalmente, a manutenção de uma comunidade virtual de aprendizagem colaborativa, são importantes elementos a serem considerados: o desejo (motivação), a empatia (partilha do desejo) e a sociabilidade moldada em um relacionamento colaborativo (manutenção do desejo).

Em relação ao processo motivacional, Kenski (2001, p. 55) afirma que a motivação é "um processo que se transforma permanentemente de acordo com os diversos momentos em que vivemos [...] É a energia interior que nos encaminha para a realização das nossas aspirações, mesmo quando não lhes damos conta no plano consciente”.

De acordo com Lumsden (1994), a motivação está relacionada ao desejo do aluno em participar no processo de aprendizagem, bem como com as razões subjacentes ao seu envolvimento ou não nas atividades acadêmicas.

Argumentando sobre motivação na aquisição da língua inglesa, Rivers (1997) afirma que o grau de motivação (quer forte ou fraco) sempre existe e que cabe ao professor desvendar o dispositivo que o aciona em cada indivíduo e a forma de canalizá-lo para que a aquisição da língua se dê em escala maior.

Brown, H. D. (1994, p. 34) apresenta a seguinte definição de motivação registrada em dicionário e extraída de diversas fontes: "Motivação diz respeito à escolha de metas a serem atingidas e aos esforços para alcançá-las" ${ }^{34}$ Com respeito à motivação intrínseca e

\footnotetext{
${ }^{34}$ No original: "Motivation is the extent to which you make choices about (a) goals to pursue and (b) the effort you will devote to that pursuit." (p. 34)
} 
extrínseca, o autor chama atenção para o fato de que se os alunos tiverem a oportunidade de aprender por motivos próprios (que os levem a atingir "competência" e "autonomia") terão mais sucesso do que se estiverem comprometidos com recompensas externas (nota, promoção, etc.) para sua motivação.

A partir desta consideração, entendo que motivação intrínseca é aquela que se relaciona com o interesse do indivíduo; é a garra e desafio que o levam a realizar um anseio ou desejo.

Para McCombs [19--] conhecer as necessidades individuais dos alunos no que tange as escolhas e decisões a serem tomadas no curso (por parte do professor), a sensação de competência e pertença ao grupo (por parte do aluno) são chaves para motivar o discente a aprender.

Por esse motivo o professor deve se mostrar atento aos alunos e aberto ao diálogo, ouvindo necessidades, reivindicações, pedindo e acolhendo sugestões. Desta forma, tentase estabelecer um clima de confiança, motivação e empatia entre o educador e os educandos e estimula-se a prática do diálogo, negociações e intervenções crítico-reflexivas entre os próprios alunos.

Para Moran (2000) a forma de se relacionar com os discentes é imprescindível para o sucesso pedagógico; daí ser fundamental que se estabeleça, desde o início, uma relação empática com eles.

Rogers (1983), por sua vez, faz menção às pesquisas de David Aspy, relacionadas à "Educação Humanizada" bem como à aproximação entre a terapia centrada no cliente e o contexto escolar. Neste "a empatia (E) foi redefinida como a tentativa do professor de compreender o significado pessoal da experiência escolar para cada aluno” (p. 101). 
Partindo do ponto de vista desses autores, interpreto a empatia como componente vital da comunicação, da interação entre pessoas, da disposição de compreender o outro. Ou, conforme Preece (1998b), a empatia afeta como comunicamos nossos pensamentos e sentimentos aos outros, como entendemos os outros, e ainda como os outros se sentem ao se comunicarem conosco. O que nos leva a concluir que a empatia é uma afinidade subjetiva que contempla as relações de trocas entre os sujeitos.

Segundo Adler (1967, p. 65) "a empatia ocorre desde o momento em que um ser humano fala com o outro. É impossível compreendermos outro indivíduo se nos for impossível identificar-nos com ele”. Complementa-se essa afirmação com a de Ickes, et al. (1990, 1993 - apud FENG, LAZAR \& PREECE, 2004). Sugerem esses autores que a empatia é mais forte entre pessoas que identificam semelhanças com os outros, ou que compartilham das mesmas experiências. Esse mesmo ponto de vista é defendido por Brooks (1999).

Todavia, Brooks (2004), em resposta ao e-mail desta pesquisadora ${ }^{35}$, ressalta que embora seja mais fácil ser empático com indivíduos que compartilham pontos de vista e têm experiências similares, isto por si só não garante que eles sejam mais empáticos.

Morin (2000, p. 95, grifo do autor) ao tratar da compreensão humana diz:

O outro não apenas é percebido objetivamente, é percebido como outro sujeito com o qual nos identificamos e que identificamos conosco, o ego alter que se torna alter ego. Compreender inclui, necessariamente, um processo de empatia, de identificação e de projeção. Sempre intersubjetiva, a compreensão pede abertura, simpatia e generosidade.

\footnotetext{
${ }^{35}$ BROOKS, R. Re: empathy [mensagem pessoal]. Mensagem recebida por <vcqm@uol.com.br> em 20 jul. 2004. No original: [...] "Although I am not certain about formal research studies, I often say in my workshops that it is easier to be empathic towards people who share our views and have similar experiences. However, such similarity does not guarantee one will be more empathic (e.g., a shy parent who has difficulty being empathic towards his or her shy child since the parent is also shy and dislikes that quality in himself/herself and consequently, in the child)." [...]
} 
Uma relação empática (tal como a percebo) é gerada por uma afinidade subjetiva que leva os indivíduos a quererem se relacionar, se comunicar; ou seja, a estabelecer uma relação de trocas, que pode ser estimulada pela prática pedagógica - a princípio em nível de compartilhamento de interesses comuns, desdobrando-se em vivência de relações afetivas.

Encontro em Lobo Sierra et al. [19--] um aporte teórico para minha afirmação:

A empatia é uma resposta afetivo-cognitiva ativada pelo estado de necessidade de outra pessoa e sua intensidade se relaciona com a rapidez da ajuda subseqüente, que também depende da informação acerca dos pensamentos, sentimentos do outro e de quanto valorizamos o bem estar deste. ${ }^{36}$

E prosseguem as autoras:

Isto nos leva a concluir que a empatia é uma aptidão de caráter subjetivo, já que depende do indivíduo que a manifesta, dadas as características de percepção como fenômeno cognitivo, implica não só na aquisição de informação imediata do ambiente, mas tem um papel importante na informação obtida através de vivências prévias e da relação que se estabelece entre ambas. ${ }^{37}$

Brooks (2004) em resposta ao e-mail desta pesquisadora complementa que a empatia envolve tanto a aprendizagem cognitiva quanto a emocional ${ }^{38}$.

Se tomarmos por base as palavras de Lobo Sierra et al. [19--], de Rogers (1983) e de Brooks (2004), certamente não incorreremos no erro de postular que - no momento em que o professor se coloca no lugar do aluno, o ouve e tenta compreendê-lo -, ampliam-se as possibilidades de identificação das necessidades do educando, de analisá-las e de atendê-las

\footnotetext{
${ }^{36}$ No original: "La empatia es uma respuesta afectiva-cognitiva activada por el estado de necessidad de outra persona y su intensidad se relaciona con la rapidez de la ayuda subsiguiente, la que también depende de la información acerca de los pensamientos, sentimientos del outro y cuánto valoramos el bienestar de ésta”.

${ }^{37}$ No original: "Esto nos lleva a deducir que la empatia es uma habilidad de caráter subjetivo, ya que es dependiente del indivíduo que la manifiesta dadas las características de la percepción como fenómeno coginitivo implica no solo la adquisición de información immediata del ambiente, sino que juega un papel importante la información obtenida a través de vevencias previas y la relación que se estabelece entre ambas".

${ }^{38}$ BROOKS, R. Re: empathy [mensagem pessoal]. Mensagem recebida por 〈vcqm@uol.com.br> em 20 jul. 2004. No original: “ [...] I should note that empathy involves both cognitive and emotional learning."
} 
de maneira mais adequada. Desta forma, criam-se condições necessárias à ocorrência de empatia entre os sujeitos envolvidos no processo de aprendizagem.

Delors (1998) mostra o quanto a empatia afeta o comportamento social do indivíduo. $\mathrm{O}$ autor também ressalta a importância de se incentivar esse sentimento em crianças. São palavras do autor:

As crianças devem ser ensinadas a compreender as reações de outras pessoas, vendo as coisas sob o prisma dessas últimas. Onde esse espírito de empatia [grifo meu] é encorajado nas escolas, ele tem um efeito positivo no comportamento social dos jovens para o resto de suas vidas". ${ }^{39}$

Por outro lado, Wiese \& Becker (1932, apud CARDOSO; IANNI, 1984, p. 136) argumentam que: "muito embora todas as relações humanas resultem de processos interhumanos, nem todas provocam relações [de aproximação]”. Essa afirmação de Wiese \& Becker nos leva a refletir sobre a natureza do comportamento humano e das relações sociais/afetivas estabelecidas entre os indivíduos.

Reid $(2004)^{40}$, por mim questionada via e-mail a respeito do significado da síndrome da comunidade empática, afirma que acredita ter sido ela a autora da expressão que descreve a colocação feita por Hiltz e Turoff em 1978 de que os interlocutores on-line viriam a desenvolver amizades via computador. Tal afirmação ${ }^{41}$ é tomada com certa cautela por Reid, nos dias atuais, uma vez que a autora acredita que tanto laços de amizade quanto de hostilidade podem ser observados na comunicação mediada por computador.

\footnotetext{
${ }^{39}$ No original: "Children should be taught to understand other people's reactions by looking at things from their point of view. Where this spirit of empathy [grifo meu] is encouraged in schools, it has a positive effect on young person's social behaviour for the rest of their lives."

40 REID, E. Re: syndrome of empathetic community [mensagem pessoal]. Mensagem recebida por <vcqm@uol.com.br> em 01 maio 2004. No original: “I think that 'syndrome of empathetic community' was my own phrase describing Hiltz and Turoff's description of online interlocutors going to great lengths to be friendly and developing strong friendships via computer."

${ }^{41}$ Idem. No original: "In fact, I think that these days any claim that computer-mediated communications is most likely to elicit positive social behavior would not be a safe one to make. The days of the socially harmonious Internet disappeared when it ceased to be demographically homogenous -- and even when it was so, there were at least as many examples of hostility as of friendship."
} 
O termo comunidade empática também aparece nos trabalhos de Preece (1998a). Essa autora faz uma distinção entre comunidades empáticas e demais grupos. Nas primeiras, a comunicação é fortemente empática e geralmente enfocam problemas pessoais ou médicos e seus membros buscam empatia e apoio emocional. Nos outros grupos, por sua vez, a comunicação entre os membros tem como objetivo principal a troca de informações.

Tomando-se por base os trabalhos de Preece (op. cit.), verifica-se que as comunidades virtuais de aprendizagem cairiam em outros grupos. Todavia, vale ressaltar que ocorrências da vida cotidiana são observadas em ambientes virtuais de aprendizagem (PALLOFF \& PRATT, 1999). Suas manifestações são, pois, assumidas como propiciadoras do desenvolvimento de empatia também nessas comunidades. Em consulta via e-mail a Feng (2004), autora que também estuda a empatia em comunidades virtuais, encontro respaldo para essa asserção feita.

Segundo Feng ${ }^{42}$, um grande número de comunidades se encontra no meio-termo entre comunidades empáticas e outros grupos. A autora acredita que a comunidade de aprendizagem é um exemplo disso, e talvez se caracterize mais como comunidade empática por ser comum encontrar conversas empáticas nessas comunidades.

Goleman (2004), outro autor consultado por e-mail sobre o significado da empatia, atesta sua maior importância na comunicação virtual. Para Goleman, uma vez que não ouvimos ou vemos nosso interlocutor quando interagimos, por exemplo, por e-mail, comprometem-se os canais de retorno emocional que geram empatia, e sem empatia tem-se

\footnotetext{
${ }^{42}$ FENG, J. Re: empathic communication [mensagem pessoal]. Mensagem recebida por 〈cqm@uol.com.br> em 14 jul. 2004. No original: "[...] A large number of communities fall in between those two extreme and I think learning community is one of them and maybe more to the empathic end. It is quite common to find empathic conversations on those communities."
} 
mais possibilidade de comunicação distorcida. $\mathrm{O}$ autor sugere que o ensino de habilidades empáticas auxilia os indivíduos em comunidades virtuais. ${ }^{43}$

Partindo dessa premissa, e levando em conta o quadro teórico apresentado, verifica-se a necessidade de o professor manifestar relações empáticas e de estimular interações que contemplem essas relações junto aos alunos, se o intuito é a consolidação de uma comunidade virtual de aprendizagem, que tenha origem em um curso on-line.

Não se pode negar, entretanto, a dificuldade que permeia a criação de laços afetivos e sociais entre os membros de um curso on-line, principalmente se for constituído por indivíduos que nunca se encontram face-a-face.

Além da empatia como fator facilitador da aprendizagem e da constituição de uma comunidade de aprendizagem, a sociabilidade (característica da espécie humana) é outro fator importante a ser considerado.

Adler (1967, p. 65) aponta para o fato de a empatia e a sociabilidade estarem associadas/relacionadas uma com a outra:

Se procurarmos a origem desta aptidão para proceder e sentir como se fossemos outra pessoa, encontrá-la-emos na existência de um inato senso de sociabilidade. Este é, de fato, um sentimento universal, um reflexo de nossa conexão com o cosmo e um infalivel característico do ser humano.

Em estudos sobre ambientes virtuais, é possível verificar que novas formas de sociabilidade estão sendo engendradas. Fundamenta Guimarães Jr. (1997), por exemplo, que "o ciberespaço, ao constituir-se em um novo espaço de sociabilidade, acaba gerando novas formas de relações sociais, com códigos e estruturas próprias”.

43 GOLEMAN, D. Re: emotional intelligences [mensagem pessoal]. Mensagem recebida por <vcqm@uol.com.br> em 19 jul. 2004. No original: “[...] Empapthy matters most for virtual communications, since if we do not hear a voice or see a face when we interact (for example, by e-mail), then we are lacking the emotional feedback channels that allow empathy. And without empathy, we are more likely to miscommunicate. So teaching empathy skills to people would help in virtual communities." 
Esta afirmação de Guimarães Jr. talvez se dê pelo fato de que os ambientes virtuais podem reunir pessoas que não têm contato pessoal fora da rede. Inclusive, podem agregar indivíduos de culturas totalmente diversas e que jamais poderiam interagir se não fosse através das possibilidades de superação dos limites de espaço e tempo, proporcionados pelas tecnologias digitais.

A respeito das novas formas de interação e de sociabilidade possibilitadas pelas redes telemáticas, Rodrigues (1994, apud MARCELO 2001, p. 65) afirma que “ $a$ comunicação não é um produto, mas um processo de troca simbólica generalizada, processo de que se alimenta a sociabilidade que gera os laços sociais que estabelecemos com os outros".

Os diversos autores referenciados fazem menção a uma nova forma de sociabilidade que está se desenvolvendo no ciberespaço. Para Maffesoli (2002) ${ }^{44}$ e para Lemos (1998), entre outros, nos encontramos em um processo de transição da sociabilidade moderna para o que denominam socialidade pós-moderna. Embora também acredite em um processo de transição, onde as relações no ciberespaço são menos formais e institucionalizadas, discordo de Lemos quando limita a socialidade "às relações banais do cotidiano; aos engajamentos efêmeros, imediatos e empáticos”. Os vínculos que se formam no ciberespaço são complexos e merecem estudos mais aprofundados. Se esse conceito de socialidade for tomado ipsis literis não dá conta das agregações eletrônicas do tipo comunitário, discutidas pelo mesmo autor.

\footnotetext{
${ }^{44}$ MAFFESOLI, M. Re: Fwd: about your expertise (a query) [mensagem pessoal]. Mensagem recebida por <vcqm@uol.com.br> em 12 maio, 2002. No original: <j'ai expliqué que la sociabilité renvoyait à l'excercice simple du social en ce qu'il a de rationnel. Alors que la socialité elle integre l'imaginaire, le ludique et l'onirique. Bien sûr que la socialité joue um rôle important dans la société postmoderne. C'est même, de mon point de vue, sa spécificité>.
} 
Enquanto Lévy (1999) considera que as vivências virtuais são importantes para qualificar as vivências territoriais, Castells (2003, p. 106) enfatiza a relevância da "passagem da limitação espacial como fonte da sociabilidade para a comunidade espacial como expressão da organização social”.

No caso de cursos on-line essas novas vivências/relações implicam em novos papéis de professor e alunos, sujeitos de um processo educacional que poderão nunca vir a se encontrar em um mesmo espaço geográfico territorialmente delimitado, e que poderão estar em presença prolongada em espaços virtuais, igualmente reais, como nos adverte Lévy (1999).

Na formação de verdadeiras comunidades virtuais de aprendizagem colaborativa, conectando pela empatia e pela sociabilidade entre seus membros, indivíduos de diferentes culturas, credos e origens, e expondo-os a diferentes visões de mundo, encontramos a oportunidade de contribuir para o aprimoramento não só intelectual do indivíduo, mas também para o desenvolvimento da pessoa, do cidadão da terra nacional/universal de que no fala Morin (2000), que começa a se constituir. Ou para futuras sociedades organizadas em modelos comunicacionais e colaborativos que se configurem como marca da universalidade sem totalidade de que nos fala Lévy (1999).

\section{2- E xigências do ex erć́dio dos novos papéis de professor e de aluno em cursos on-line}

A literatura sobre os novos papéis de professor e de aluno em situação de ensino presencial, semipresencial ou on-line é vasta. Dentre os vários autores que abordam o tema, 
encontram-se Berge (1996), Kenski (2001), Masetto (2000), Moran (1998, 2000), Palloff \& Pratt (1999, 2001), Perrenoud (2000), entre tantos outros.

A resignificação do papel de professor e de aluno nas sociedades tecnológicas da atualidade é relevante tanto para situações de ensino em geral e para o novo contexto cibernético aqui focalizado.

O que deve mudar na relação entre educador e educando para suprir as novas exigências educacionais da sociedade contemporânea?

O aluno $^{45}$ precisa deixar de ser mero receptor de informações e ser estimulado/orientado a conquistar sua autonomia, a ser mais participativo, e a se conscientizar da importância em assumir a parte que a ele cabe de sua aprendizagem.

Garrido (2001, p. 131), embora não se refira à aprendizagem em ambiente virtual, ressalta esse mesmo ponto de vista, ao afirmar que "ao fazer os alunos pensarem por eles, $o$ professor está favorecendo a autonomia intelectual [grifo meu] do aluno e preparando-o para atuar de forma competente, criativa e crítica como cidadão e profissional".

Isto, todavia, pode apresentar dificuldades para o educando em sua experiência educativa, se o professor for tido como aquele que lhe delega o conhecimento do qual ele é mero receptor.

O aluno precisa, doravante, aprender a gerenciar seu próprio tempo de estudo, administrar as relações de aprendizagem com seus colegas, ou exercitar relações colaborativas, por exemplo. A inabilidade em lidar com estas questões pode gerar desmotivação e resultar em sub aproveitamento, ou em evasão do curso. É, portanto, preciso

\footnotetext{
45 A respeito do comportamento verificado por parte dos alunos de cursos on-line, ministrados por Dr. Guy Bensusan, ver o artigo escrito pelo autor: In Praise of Learners. Education at a Distance. July 2001, v. 15, $\mathrm{n}^{\mathbf{o}}$ 7, baseado em perguntas, por mim a ele enviadas, via e-mail. Disponível em:

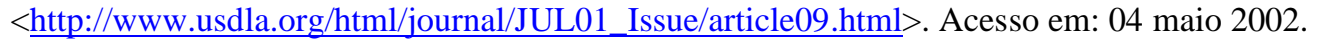


estimular essas competências ${ }^{46}$ dos alunos e desenvolver (se não mesmo criar) o valor cultural da ação colaborativa no desenvolvimento da autonomia intelectual.

O novo professor, assim, precisa deixar de ser a autoridade pretensamente máxima centralizadora do conhecimento-, e se tornar a autoridade democrática, o coordenador das relações com o saber.

De acordo com Penteado (2003, p. 59), o professor “coordena no espaço escolar um trânsito de diferentes tipos de conhecimento [...] (e) a organização de atividades de aprendizagem apoiadas em situações-problema” que ele professor cria e cuja solução é dada pelo aluno sob orientação do docente.

E ainda que,

A nova conduta desejada envolve comportamentos docentes de ouvir e expressar-se, combinar pontos de vista, ordenar contribuições e experiências diversas, problematizar colocações, explicitar contradições, informar conhecimentos já produzidos, provocar reflexões, em busca da construção conjunta de um conhecimento mais elaborado.

(PENTEADO, 2002, p. 16)

Para tanto é preciso refletir sobre e analisar a prática docente, compreender os diferentes estilos de aprendizagem de cada aluno, e a dinâmica do grupo com o qual se está trabalhando.

Essas novas exigências, sem dúvida alguma, geram muitos conflitos e questionamentos para professores e alunos identificados ou acomodados com a situação tradicional e que, de repente, se vêem diante das novas exigências da sociedade atual. A ruptura com o velho paradigma educacional e com práticas pedagógicas que contemplam o

\footnotetext{
${ }^{46}$ Estou usando o termo competência no sentido utilizado por Perrenoud (2000, p. 15), ou seja, como capacidade de mobilizar diversos recursos cognitivos para enfrentar um tipo de situação, incluindo entre eles os saberes ou campos de conhecimento específicos.
} 
autoritarismo, a comunicação verticalizada é difícil, por estar ainda fortemente arraigada nos modelos educacionais vigentes.

As questões a elucidar são como fazer e o que considerar para implementar tal transformação, que uma vez praticada, poderá trazer enriquecimento tanto para os docentes quanto para os discentes.

Ao repensarmos nosso papel de docente, poderemos mais facilmente descobrir formas de ajudar a conscientizar nossos alunos e a nós mesmos de que podemos compartilhar o status de co-autores no exercício do ensino e de nossos respectivos papéis de professor e de aluno.

A parceria que deve existir entre ambos (professor e alunos) é mencionada por diversos autores, dentre eles, por Behrens (2000), Moran (1998, 2000), Masetto (2000) e Penteado $(2002,2003)$.

Masetto define o professor através de uma metáfora interessante: “uma ponte entre o aprendiz e sua aprendizagem - não uma ponte estática, mas uma ponte 'rolante' que ativamente colabora para que o aprendiz chegue aos seus objetivos" (p. 145) ${ }^{47}$. Destaca assim o caráter interativo e dinâmico da comunicação plural entre professor e alunos e dos alunos entre si, tão importante nos dias de hoje.

Na visão de Palloff e Pratt (1999), os papéis dos alunos e do professor se misturam e são interdependentes, o que mostra o caráter democrático deste modelo de ensinoaprendizagem.

\footnotetext{
47 Metáfora semelhante à de Masetto é utilizada por Gates ao definir os professores bem-sucedidos como "escoadores criativos e pontes de comunicação com o mundo". (p. 248). Gates mostra-se contraditório ao fazer uso dessa metáfora, pois ao definir o professor como escoador está tendo uma visão tradicional de unilateralidade da comunicação professor-aluno, mas ao usar o termo ponte de comunicação mostra uma visão moderna, de bi-direcionamento da comunicação.
} 
Com a tecnologia os conceitos de aula, espaço, tempo, individualidade e coletividade devem ser revistos, pois ela propicia novas formas de o professor e os alunos estarem juntos, ainda que fisicamente separados pela distância geográfica.

A resignificação dos conceitos de espaço (não mais limitado a um espaço físico, a uma sala de aula) e de tempo (não mais restrito ao tempo cronológico estabelecido linearmente pela passagem dos dias e horas) não mais restringe as possibilidades de comunicação do ser humano.

A mudança gerada pela revolução tecnológica na nossa percepção de espaçotemporal nos leva a vivenciar “uma sensação de tempo real, imediato, 'livre', e de abolição do espaço físico-geográfico" (LEMOS, 2003).

Torna-se possível então a interação e comunicação a qualquer hora/dia com pessoas de qualquer parte do mundo, o que amplia as possibilidades de exploração de novas experiências interpessoais, culturais e educacionais. Tal afirmação apóia-se em Lévy (1998c, p. 21), quando o autor diz que:

Quando uma pessoa, uma coletividade, um ato, uma informação se virtualizam, eles se tornam 'não-presentes', se desterritorializam. Uma espécie de desengate os separa do espaço físico ou geográfico ordinários e da temporalidade do relógio e do calendário. É verdade que não são totalmente independentes do espaço-tempo de referência, uma vez que devem sempre se inserir em suportes físicos e se atualizar aqui ou alhures, agora ou mais tarde. No entanto, a virtualização lhes fez tomar a tangente.

Outro conceito que merece revisão é o de distância. Tori (2000) aponta para o fato de que no processo de ensino-aprendizagem o que deve ser levado em conta é a efetiva sensação de distância entre professor e alunos, e não a distância física real que os separa. E ainda que para se conseguir melhores resultados pedagógicos em EAD, deve-se procurar eliminar as distâncias entre professor e alunos. 
Para Moore (1993), em qualquer situação educacional, a distância na educação não é definida pela separação geográfica entre professor e aluno, mas pela distância psicológica e comunicacional entre os sujeitos envolvidos no ensino-aprendizagem. Para o autor, a distância é marcada pela rigidez da estrutura (controle exercido pelo instrutor ou instituição educacional) e pela flexibilização de diálogo (controle exercido pelo aprendiz). E ainda, que uma estrutura mais rígida tende a aumentar a distância, enquanto que maior diálogo tende a diminuí-la.

Tendo-se em vista esses conceitos, a distância entre os sujeitos da aprendizagem pode ser reduzida no ensino-aprendizagem on-line, uma vez que o professor e os alunos, e os próprios alunos entre si, passam a poder dialogar mais e a serem mais sensíveis tanto às peculiaridades, interesses, estilos e ritmos de aprendizagem individuais quanto às necessidades do grupo. Esse grau de distância também passa a ser menor à medida que se desenvolvem as relações empáticas e a sociabilidade no grupo.

A rede digital é um meio de comunicação ainda em fase experimental e embrionária, mas que pode ajudar a nós, educadores, a revermos e modificarmos muitas das atuais práticas pedagógicas de ensinar e de aprender.

Segundo Spector e la Teja (2001) muito do que se tem publicado sobre o ensino on-line tem como enfoque as habilidades técnicas e os requisitos para uma bem sucedida moderação e facilitação de discussões e de sessões de chat. Afirmam eles, que a literatura sugere treinamento, uma vez que atuações on-line requerem competências singulares.

Sobre a competência do professor, Lévy (1999, p. 171) esclarece que esta "deve deslocar-se no sentido de incentivar a aprendizagem e o pensamento". Essa visão tal qual 
concebida pelo autor, mostra a nova conduta a ser seguida por um docente cujo método de ensino supõe um “regramento” construído de maneira coletiva com seus alunos.

A redefinição do papel do professor aponta também para um refinamento de competências profissionais que se consubstanciam na metodologia comunicacional de ensino. Essa metodologia lida com o processo educacional que se desdobra, segundo Penteado (2002) em todas as instâncias decisórias da docência (planejamento, elaboração de objetivos, recorte de conteúdo, decisão de procedimentos e avaliação) através do agir comunicacional.

Para Penteado, o agir comunicacional reconhece "as interferências sociais $e$ culturais" nos processos de comunicação e se desloca de uma “atuação linear" de trabalho para uma "atuação em rede". O agir comunicacional apresenta como características "se realizar de forma processual, compreender as vozes do professor e dos alunos, ter presente as mídias interativas e resignificar as mídias massivas (livro; rádio; TV; cinema)”, entre outras. Essa forma de atuação mostra uma mudança no papel do professor, em pauta nos dias atuais.

Do exposto pelos vários autores referenciados, vê-se a necessidade de o professor desenvolver novas competências, principalmente, se estiver envolvido na elaboração, implementação, oferecimento e execução de cursos na modalidade on-line.

Em situações de ensino mediado por tecnologia digital as competências do professor vão além do domínio de conteúdo específico de sua área de conhecimento, atuação, estudo e especialização; dos procedimentos de ensino pertinentes à sua disciplina, e das formas de avaliação do processo de ensino-aprendizagem. Espera-se que esse professor tenha conhecimento, pelo menos razoável, de uso do computador, de navegação 
através da estrutura lógica hipertextual que caracteriza a Web, dos serviços oferecidos através da Internet e de ferramentas digitais para o ensino on-line. Além disso, ele precisará desenvolver formas de despertar nos alunos on-line interesse, motivação, atitudes empáticas e de sociabilidade colaborativa.

No que diz respeito às funções exercidas pelo docente que atua na modalidade online, Berge (1996) as apresenta categorizadas em quatro áreas principais: pedagógica, social, de gerenciamento e técnica, embora destaque que nem todas as funções precisam ser desempenhadas em sua totalidade por uma única pessoa. Inclusive, penso que na prática trata-se de um trabalho em parceria, dependente de saberes de natureza diversa.

Entre as recomendações pedagógicas cita, por exemplo: ter objetivos claros, encorajar a participação dos alunos, manter um estilo não autoritário de relacionamento, propor tarefas simples e abstenção do ensino discursivo.

Entre as sociais, destaca, por exemplo: acolher lurkers (aqueles que não participam ativamente das discussões, apenas "ouvem" os outros), facilitar a interação, evitar sarcasmo e flames (discussões violentas) e incentivar apresentações (para ajudar a criar um senso de comunidade).

Com relação às recomendações gerenciais, menciona, entre outras, a informalidade, responder prontamente a cada contribuição, ser paciente e claro.

Finalmente, sobre as recomendações técnicas, aponta: o auxílio do suporte técnico, dar tempo para que o aprendiz se familiarize com a tecnologia e promover aprendizagem entre colegas, entre outras. 
Na proposta de Berge (1996), a área pedagógica dá conta do papel do moderador/tutor on-line como facilitador do processo de aprendizagem. A social refere-se à criação de um ambiente amigável, da valorização das contribuições dos alunos, do desenvolvimento do senso de coesão do grupo, entre outros aspectos. A área de gerenciamento, por sua vez, dá conta do cenário onde ocorrem as interações entre os participantes: objetivos da discussão, horário das atividades, regras de procedimento, etc., e a área técnica destaca a importância de o facilitador fazer com que os participantes se sintam confortáveis com a tecnologia e com o software, possibilitando, assim, a concentração nas tarefas pedagógicas.

Moran (2000) oferece uma classificação um pouco diferente e que se aplica ao professor em geral (e não exclusivamente aquele que atua via Internet) e é apresentada da seguinte forma: orientador/mediador intelectual (ao ajudar o aluno a se apropriar do conhecimento); orientador/mediador emocional (ao motivar e estimular o aluno); orientador/mediador gerencial e comunicacional (ao gerenciar processos e ajudar o aluno a desenvolver formas de comunicação), e orientador/mediador ético (ao ajudar na construção de valores individuais e sociais).

Com relação aos papéis exercidos pelo professor on-line, Berge (2003), em resposta ao e-mail a ele por mim enviado, afirma que não faz grande distinção entre os termos "on-line tutor", "on-line teacher" e "on-line instructor", já que as funções do docente são as mesmas, sejam elas exercidas na modalidade on-line ou presencialmente ${ }^{48}$.

\footnotetext{
${ }^{48}$ BERGE, Z. L. Re: On-line Tutor [mensagem pessoal]. Mensagem recebida por <vcqm@uol.com.br> em 16 fev. 2003. No original: "[...] I think it would depend on whether there is any differences between these roles in the common parlance of the system under review. Just because the word "on-line" appears before each, doesn't really change their function in the educational system they are found.

For instance, I don't draw much distinction between an on-line tutor and an on-line teacher nor an on-line instructor. HOWEVER, this may be simply that I am most famailar with education in the United States. [...]
} 
Paulsen (1995) é outro autor que atribui ao professor on-line diversos papéis (tutor, facilitador, moderador, provocador, entre outros) e afirma que cada papel é marcado por elementos organizacionais, sociais e intelectuais. E ainda, conforme esse mesmo autor (2004), em resposta ao meu e-mail a respeito dos diferentes termos empregados para descrever o papel do professor on-line, diz que cada uma dessas terminologias apresenta nuanças conceituais diferentes, o que implica em se poder usar todas elas ${ }^{49}$.

Refletindo sobre as colocações dos autores estudados, entendo como Paulsen as várias funções do professor. Dependendo das diferentes situações docentes em que atua, evidencia-se o papel de mediador, tutor, facilitador, provocador, que exerce junto aos alunos no processo de ensino-aprendizagem. Todas as funções são, entretanto, permeadas pela atitude de coordenação, mencionada por Penteado (2002, 2003).

A figura do professor continua, pois, relevante na contemporaneidade. Leffa (2001) destaca que: “a mundialização aliada à necessidade de acesso a um saber cada ver mais dinâmico, torna o trabalho do professor imprescindivel na sociedade atual."

Para Tori (2000), a idéia de que o profissional o professor é dispensável em cursos mediados por tecnologia digital é um mito. Sua figura se torna mais necessária, pois a ele cabe a proposta programática, a elaboração do material, a apresentação do curso e o acompanhamento dos alunos. O que, na perspectiva da metodologia comunicacional de ensino compreende coordenar idéias, processos de sociabilidade, trabalhos pessoais e

My point is, there isn't anything magical about the delivery system to me. A teacher or professor or instructor has a certain role(s) that is the same whether teaching is done on-line or in-person. [...]"

${ }^{49}$ PAULSEN, M. Re: query [mensagem pessoal]. Mensagem recebida por < vcqm@uol.com.br> em 27 mar. 2004. No original: "I would use the same terms in online teaching as in other teaching environments. Since the terms you mention have slightly different meanings in traditional teaching environments, I would say that they also have different meanings in an online setting. So I would use all the words (online tutor, online facilitator, online moderator, online provoker) to exploit the nuances in the English language." 
coletivos, além de dever promover, no caso da educação on-line, uma familiarização ou intimidade cada vez maior com o meio tecnológico.

\section{3- C urso on-line: visão geral sobre metodologia de ensino-aprendizagem}

Como as metodologias adotadas em cursos on-line ainda se mostram incipientes, somente através de estudos e pesquisas sobre atuações conjuntas de docentes e discentes em situações de ensino on-line é que será possível avaliar as melhores condutas a serem utilizadas nesta modalidade de ensino.

Para a construção de uma metodologia de ensino-aprendizagem que se estabelece aos poucos e com a colaboração de todos (professor e alunos), cabe ao educador criar condições que provoquem e encaminhem a participação dos educandos entre si e com o professor nas relações com o conhecimento travadas no processo de aprendizagem.

Lévy (1999, p. 158) discorrendo sobre o novo modelo pedagógico considera que:

[...] o essencial se encontra em um novo estilo pedagógico, que favoreça ao mesmo tempo as aprendizagens personalizadas e a aprendizagem coletiva em rede. Nesse contexto, o professor é incentivado a tornar-se um animador da inteligência coletiva de seus grupos de alunos em vez de um fornecedor direto de conhecimentos.

Moran (2000, p. 13) apresenta posicionamento semelhante ao de Lévy ao afirmar que:

Ensinar é um processo social (inserido em cada cultura, com suas normas, tradições e leis), mas também é um processo profundamente pessoal: cada um de nós desenvolve um estilo, seu caminho, dentro do que está previsto para a maioria. 
No caso de se trabalhar em cursos on-line com alunos procedentes de diferentes países e culturas - e tomando-se como base a fala de Moran-, faz-se necessário nos determos nas características culturais do processo de ensino-aprendizagem de que provêem esses alunos, em suas práticas e realizações, desvendando tanto quanto possível, os pontos comuns e divergentes neles existentes para, a partir daí, considerar as intervenções adequadas a uma metodologia de ensino on-line para esse público alvo.

Por se tratar de uma prática educacional exercida em uma nova situação de ensino, uma reflexão sobre diferentes teorias/abordagens pedagógicas até hoje construídas poderá ser útil no sentido de nos despertar para necessidades de uma transformação na situação de ensino on-line.

Parson $(2001)^{50}$, por mim consultada por e-mail, afirma que o ambiente virtual é melhor definido pelo construtivismo de Vigotsky. Palloff $(2001)^{51}$, também por mim consultada por e-mail, confirma que a tendência é por uma forma construtivista de ensino na modalidade on-line, o que gera uma nova maneira de ensinar e aprender no ambiente virtual. Por outro lado, Elliott $(2001)^{52}$ em resposta a meu $e$-mail para a lista de discussão COLLABORATE $^{53}$ considera que debates sempre ocorrerão na academia a respeito dos méritos relativos do construtivismo versus um grande número de outras teorias.

\footnotetext{
${ }^{50}$ PARSONS, T. Re: response to help [mensagem pessoal]. Mensagem recebida por vcqm@uol.com.br em 08 mar. 2001. No original: "[...] A virtual Real World environment is best defined by Vygotsky's 'Constructivism.','

${ }^{51}$ PALLOFF, R. Re: online community [mensagem pessoal]. Mensagem recebida por vcqm@uol.com.br em 07 maio 2001. No original: "[...] -- You're right when you say that the tendency is a constructivist way of teaching online. The online environment is perfect for that means of delivering a class and creates a whole new way of teaching and learning."

${ }^{52}$ ELLIOTT, R. Re: Using web course management tools [mensagem pessoal]. Mensagem recebida por vcqm@uol.com.br em 03 maio 2001. No original: “[...] I am sure that endless debate will always occur throughout academia on the relative merits of constructivism versus a raft of other theories. [...]".

${ }^{53}$ Lista de discussão que tem como objetivo principal dar apóio e explorar a aprendizagem colaborativa na rede.
} 
Caso se entenda a aprendizagem como decorrente de um processo de trocas (do sujeito) com o meio, há de se atentar para as teorias construtivistas e de comunicação que lhe dão subsídio.

Enquanto autores, como Vigotsky (1991) enfatizam a relevância da interação social no processo de aprendizagem, Penteado (1999), pesquisadora da Pedagogia da Comunicação, ressalta que esta pedagogia concebe o ensino como processo de comunicação dialógica, cuja especificidade se explicita nas necessárias relações com o conhecimento e dá poder para que todos os interlocutores possam se expressar.

A comunicação é a base das interações sociais, e, portanto, deve ser valorizada pelo professor que enfatiza a participação efetiva de seus alunos no processo de aprendizagem. É durante a comunicação que ocorrem as trocas de idéias, as discussões, e, até mesmo, os conflitos entre os sujeitos integrantes de um grupo.

Uma metodologia de ensino-aprendizagem on-line que priorize as relações intra e interpessoais pode também se alicerçar na proposta dos pilares, salientados por Delors (1998) no Relatório para a UNESCO da Comissão Internacional sobre Educação para o século XXI.

O autor apresenta uma proposta educacional assentada em quatro pilares, a saber: aprender a conhecer, aprender a fazer, aprender a viver juntos e aprender a ser. O primeiro pilar refere-se ao desenvolvimento de mecanismos de conhecimento do mundo a sua volta; o segundo, ao desenvolvimento de desempenhos pessoais; o terceiro inclui a descoberta do outro, a interdependência entre pessoas; e finalmente o quarto diz respeito ao desenvolvimento de ser integrado que ocorre no processo dialético do conhecimento do outro e de si próprio nas relações sociais. 
Para a consecução de uma metodologia de ensino-aprendizagem on-line que tem como características básicas: a ênfase na comunicação; a construção conjunta do conhecimento através das interações sociais, e o enfoque no indivíduo e seu desenvolvimento em relação ao meio (físico, social e cultural) em que vive, encontra na pedagogia da comunicação, no construtivismo e proposta educacional de Delors bases teóricas para esse fim.

1.3.1- Communicative L anguage T eaching (CL T): uma abordagem ${ }^{54}$ metodológica do ensino da língua inglesa.

No que diz respeito ao ensino de língua inglesa, várias são as abordagens metodológicas encontradas na literatura. Nesta pesquisa, dá-se destaque ao Communicative Language Teaching (CLT), surgido, no final dos anos 70 e início dos 80, da preocupação dos lingüistas aplicados com a língua (LARSEN FREEMAN, 2004) ${ }^{55}$ e inspirado pelas teorias do construtivismo.

\footnotetext{
${ }^{54}$ Penso ser importante ressaltar o conceito de abordagem por mim adotado nesta pesquisa, que se baseou na definição encontrada em RODGERS, T. S. Language Teaching Methodology. ERIC Clearinghouse on Languages and Linguistics. Digest. Issue Paper, Sep. 2001. Disponível em: <http://www.cal.org/resources/digest/rodgers.html〉. Acesso em: 29 maio 2004. Abordagens representam filosofias do ensino da língua que podem ser interpretadas e aplicadas de diferentes formas na sala de aula, distinguindo-se de métodos que são sistemas fixos de ensino com técnicas e práticas prescritas.

${ }^{55}$ LARSEN FREEMAN, D. Re: query about methodology [mensagem pessoal]. Mensagem recebida por <vcqm@uol.com.br> em 20 maio 2004. No original: “[...] Communicative language teaching (I use the term CLT, not communicative language learning) originated wtih applied linguists' concerns about language. Applied linguists in the late 1970s and early 1980s advocated for a functional approach to language--putting the emphasis on what people do with language. Prior to that point in time, a structural approach to language prevailed. [...]"
} 
Os pressupostos da abordagem CLT servem como base teórica para nosso trabalho. Para tanto, é imprescindível mencionar os preceitos que a norteiam.

Dentre a ampla gama de princípios do CLT, apresentados por Rodgers (2001), destacam-se:

$>\mathrm{O}$ aprendiz aprende a língua para se comunicar;

$>$ A comunicação autêntica e significativa deve ser a meta das atividades realizadas em sala de aula;

A fluência é uma importante dimensão da comunicação;

A comunicação envolve a integração de diferentes habilidades lingüísticas;

A aprendizagem é um processo de construção criativa e envolve tentativa e erro.

Finocchario \& Brumfit (1983, apud BROWN, H. D., 1994) apresentam uma vasta lista de características do CLT, da qual selecionamos as mais representativas do curso de inglês on-line que oferecemos.

$>$ A aprendizagem da língua está relacionada a aprender a se comunicar;

$>$ A tentativa de comunicação é estimulada desde o início;

$>$ O sistema lingüístico da língua alvo ${ }^{56}$ é aprendido através do processo de tentativa de se comunicar;

$>$ A meta é o desenvolvimento da competência comunicacional;

A interação entre os alunos é esperada.

\footnotetext{
${ }^{56}$ Língua alvo (em inglês "target language”) é a língua a ser aprendida/estudada.
} 
Uma vez que a língua é concebida como instrumento de comunicação e de interação entre os indivíduos, é fundamental encorajar o aluno, desde o início, a fazer uso da língua estrangeira, tendo em vista a transmissão do conteúdo. Não se tem mera preocupação com a forma (estrutura sintática/gramatical), a menos que esta interfira na comunicação, pois isso impediria o aprendiz de tentar se expressar livremente na língua alvo.

Com os mesmos princípios básicos do CLT, outras abordagens metodológicas surgiram, como por exemplo, a aprendizagem colaborativa que destacamos em nosso estudo e apresentamos no item 2 desta pesquisa.

Embora CLT e a aprendizagem colaborativa estejam interligadas - a diferença entre elas recai no ponto de partida e no enfoque que se quer dar (ao uso da língua como instrumento de comunicação, ou à aprendizagem realizada em grupo $)^{57}$.

As atividades didáticas, vinculadas às abordagens em foco, seguem normalmente o seguinte modelo: atividades monitoradas pelo professor; semi-monitoradas e livres. Nestas últimas, espera-se que o aluno apresente maior grau de desempenho lingüístico, uma vez que se constitui na repetição da atividade previamente monitorada pelo professor ou em uma atividade semelhante àquela. Por isso, intervenções são feitas pelo docente somente se solicitadas pelo(s) aluno(s) ou se forem observadas distorções/problemas na comunicação.

Brown, H. D. (1994) chama atenção para o fato de que nas atividades realizadas em grupos a responsabilidade da ação e progresso de cada indivíduo se dão de forma basicamente igualitária.

57 Comentário feito por LARSEN FREEMAN. Re: query about methodology. [mensagem pessoal]. Mensagem recebida por vcqm@uol.com.br em 20 maio, 2004. 
Em suma, os princípios que norteiam as abordagens aqui apresentadas coadunam com uma proposta metodológica que enfatiza aspectos cognitivos e interativocomunicacionais do aprendizado.

2.- A prendizagem colaborativa

\section{1.- C onceito de colaboração vs cooperação}

No que se refere aos conceitos de 'colaborar' e de 'cooperar', não existe consenso quanto à sua utilização, nem mesmo entre os lexicólogos. Existem autores que definem colaborar como sinônimo de cooperar. Outros tentam estabelecer diferenças conceituais entre os termos, a partir de características a eles associadas, nuanças estas que focalizaremos a seguir.

Em consulta ao dicionário Aurélio (1988), verifica-se que o mesmo não registra diferença entre os termos colaborar e cooperar. Entretanto, esses termos não são usados indistintamente, como pode ser observado, por exemplo, em slogans de campanhas: Colabore com a campanha. A forma: Coopere com a campanha, não é usual ou corriqueira. Inclusive, em uma rápida pesquisa na Internet, sobre os slogans acima, realizada em 18 de jan. de 2003, através do sistema de busca do Google (http://www.google.com.br) - , resultou em 2. 870 entradas para colaborar contra 274 para cooperar.

O dicionário de inglês The American Heritage Dictionary (1994) ${ }^{58}$ registra conotação negativa dada à palavra cooperar quando apresentada como definição para

\footnotetext{
${ }^{58}$ No original: Collaborate. 2. To cooperate treasonably, as with an enemy occupying one's country.
} 
colaborar, enquanto que o Collegiate Dictionary - Merriam Webster On-line ${ }^{59}$ assinala a etimologia desses dois termos, oriundos do latim antigo, e os define como trabalhar. Todavia, a expressão "trabalhar junto" é apresentada por esse dicionário como definição apenas para colaborar.

Já o posicionamento de Maçada e Tijiboy (1998), a partir da revisão da literatura por elas realizada, é de definir os termos cooperação e colaboração como:

[...] o conceito de cooperação é mais complexo, pois pressupõe a interação e a colaboração, além de relações de respeito mútuo e não hierárquicas entre os envolvidos, uma postura de tolerância e convivência com as diferenças e um processo de negociação constante.

Para as autoras a principal diferença entre os termos está no fato de que para se ter “colaboração um indivíduo deve interagir com o outro, existindo ajuda - mútua ou unilateral. Para existir cooperação deve haver, interação, colaboração, mas também objetivos comuns, atividades e ações conjuntas e coordenadas”.

Pela asserção feita por Maçada e Tijiboy com relação aos vocábulos ‘colaboração’ e ‘cooperação', percebe-se que elas não deixam clara a distinção entre os dois conceitos, pois nos dois há interação e objetivos comuns. A diferença fundamental entre esses termos, segundo essas autoras, é que a colaboração pode ser uma ação unilateral, ao passo que a cooperação supõe interação em ações conjuntas e coordenadas.

Se tomarmos por referência os slogans comerciais de campanhas (colabore com...), teremos que admitir, conforme Maçada e Tijiboy, o caráter de 'ajuda unilateral' como um dos conceitos ligados ao termo colaboração. Todavia, não é esse o conceito que se vincula ao trabalho educacional realizado em grupos.

\footnotetext{
${ }^{59}$ No original: (Collaboration) Etymology: Late Latin collaboratus, past participle of collaborare to labor together, from Latin com- + laborare to labor.

(Cooperation) Etymology: Late Latin cooperatus, past participle of cooperari, from Latim, co- + operari to work.
} 
Outros pesquisadores conceituam colaboração e cooperação de forma contrária daquela apresentada, por exemplo, por Maçada e Tijiboy. Dillenbourg (1999), Larocque \& Faucon (1997) e Panitz (1996), entre outros, declaram que na colaboração todos trabalham conjuntamente, visando um mesmo objetivo, sem que haja uma hierarquia de poder. Na cooperação, entretanto, existe uma certa ordem a ser seguida e é controlada por uma forma recomendada ou de imposição.

Essa diferenciação complementa-se ainda com a resposta de Dillenbourg (2002) à questão que lhe formulei por e-mail sobre o significado dos dois termos. Para o autor, a colaboração requer inter-relações mais intensas do grupo do que a cooperação ${ }^{60}$.

Panitz (1996) faz uma distinção interessante entre colaboração e cooperação. Diz o autor que "colaboração é uma filosofia de interação e estilo de vida pessoal onde os indivíduos são responsáveis por suas ações, inclusive aprendizagem e respeito às habilidades e contribuições dos pares". 61 Enquanto cooperação é "uma estrutura de interação planejada para facilitar a consecução de um produto final específico através do trabalho em grupos", 62

Percebe-se, através da colocação feita pelo autor, uma diferença qualitativa mais nítida entre os dois termos. Enquanto 'colaboração' refere-se à atitude de disponibilidade, ao engajamento legítimo de cada um dos membros do grupo, 'cooperação' diz respeito a uma forma administrada dessa atitude, tendo em vista um dado produto final.

\footnotetext{
${ }^{60}$ DILLENBOURG, P. Re: a query. [mensagem pessoal]. Mensagem recebida por vcqm@uol.com.br em 18 jun. 2002. No original: “[...] collaboration requires more intensive group interrelations”.

${ }^{61}$ No original: "Collaboration is a philosophy of interaction and personal lifestyle where individuals are responsible for their actions, including learning and respect the abilities and contributions of their peers."

PANITZ, T. A definition of Colaborative vs Cooperative learning. 1996. Disponível em: <http://www.lgu.ac.uk/deliberations/collab.learning/panitz2.html>. Acesso em: 04 jul. 2002.

${ }^{62}$ No original: "Cooperation is a structure of interaction designed to facilitate the accomplishment of a specific end product or goal through people working together in groups.” Ibidem.
} 
Assim sendo, é possível pensar que na colaboração a produção final resulta de um conhecimento coletivo (ou de uma inteligência coletiva, conforme afirma LÉVY, 1998a), onde cada indivíduo reflete sobre e "dialoga" com o pensar do outro. Na colaboração, o destaque maior é dado ao processo dialógico e às interações entre os sujeitos, e não ao resultado final.

Segundo Crook $^{63}$, a colaboração provavelmente cria relacionamentos mais ricos, uma vez que é uma forma mais plena de intersubjetividade ${ }^{64}$.

Esse percurso pela literatura anteriormente apresentada e minha experiência como docente em cursos de inglês presenciais em centros binacionais de idiomas, que enfatizam o trabalho realizado de forma colaborativa - em pares ou em pequenos grupos -, e minha experiência em cursos colaborativos on-line, levam-me a compreender a colaboração como uma filosofia (conforme PANITZ, 1996) orientadora de uma atuação flexível, que não prevê restrições de cunho hierárquico e que inclui o respeito mútuo às diferenças individuais e culturais e a liberdade nas trocas de idéias e opiniões. Desse modo, é resultado de uma inteligência coletiva (LÉVY, 1998a) e de uma maior intersubjetividade (CROOK, 2002).

Um ponto fundamental que decorre de toda essa teorização apresentada e que não pode deixar de ser abordado é aquele que questiona: Como a cooperação e a colaboração se expressam em sociedades altamente competitivas como a nossa (brasileira)? Se aceitarmos a

\footnotetext{
${ }^{63}$ Vale ressaltar que Crook, dentre outros títulos e trabalhos acadêmicos, é redator do Journal of Computer Assisted Learning <http://jcal.info/>. Suas pesquisas versam sobre desenvolvimento cognitivo de abordagem sócio-cultural, desenvolvimento psicológico de aprendizagem colaborativa, aprendizagem colaborativa mediada por computador, entre outras.

${ }^{64}$ CROOK, C. Re: a query [mensagem pessoal]. Mensagem recebida por <vcqm@uol.com.br> em 19 jun. 2002. No Original: "collaboration is a richer form of intersubjectivity and thus likely to lead to richer relationships $[\ldots]$ ”.
} 
argumentação de Lévy $(2002)^{65}$ quando o autor discorre sobre os processos que levam ao desenvolvimento da inteligência coletiva: cooperação competitiva e competição cooperativa, encontramos resposta para essa pergunta. Para Lévy, trata-se de um "jogo cooperativo" e ao mesmo tempo um "processo competitivo", onde o progresso do saber se dá através da liberdade de se expor idéias contrárias àquelas admitidas. Argumenta ainda o autor que "é porque existe essa possibilidade de competição que existe a cooperação" e mais que a inteligência coletiva resulta do equilíbrio entre "o aspecto da liberdade - que é o aspecto competição e o aspecto do vínculo social, da amizade - que é o aspecto cooperação". Portanto, os termos cooperação/colaboração e competição não são excludentes ou antagônicos, mas se complementam.

\section{2.- 0 significado da aprendizagem olaborativa}

Atualmente, na esfera empresarial, política, econômica e educacional, fala-se da necessidade de engajar os cidadãos em projetos e trabalhos em equipe, geralmente, de natureza não hierárquica. O grupo é visto como uma entidade dinâmica, catalizadora do poder individual em poder coletivo, em que o intercâmbio entre as competências e reais potencialidades de cada um de seus integrantes resulta no enriquecimento do grupo como um todo e de cada um, em diferentes proporções.

$\mathrm{Na}$ esfera educacional que enfoque deve ser dado à aprendizagem para que ela estimule práticas colaborativas?

\footnotetext{
${ }^{65}$ LÉVY, P. As Inteligências Coletivas. Palestra proferida no SESC, Vila Mariana em 29 de agosto de 2002. Disponível em: 〈http://www.sescsp.org.br/sesc/hotsites/pierre levy/Conferencia.doc>. Acesso em: 10 set. 2002.
} 
Embora meu estudo enfoque a importância da aprendizagem colaborativa, sinto ser necessário apresentar uma visão teórica a respeito desses dois tipos de aprendizagem: colaborativa e cooperativa e meu posicionamento a respeito disso.

De acordo com o Instructional Consultation da Universidade da Califórnia, Santa Bárbara $^{66}$, os termos aprendizagem colaborativa e aprendizagem cooperativa se confundem e são geralmente usados indistintamente. Apesar disso, mostra que a aprendizagem colaborativa é um termo "guarda-chuva" que abrange desde pequenos projetos em grupos até formas mais específicas de trabalhos conjuntos denominados aprendizagem cooperativa. Da definição apresentada pode-se depreender que o conceito de aprendizagem colaborativa (aqui exposto) é o mais abrangente, o que nos remete ao conceito de colaboração apresentado por Dillenbourg (1999), Larocque \& Faucon (1997) e Panitz (1996).

Segundo meu ponto de vista - baseado na literatura consultada a respeito da diferença entre os termos colaboração e cooperação -, é possível afirmar que um curso é sempre cooperativo, se considerarmos que essa modalidade de ensino supõe sempre papéis diferenciados (professor e alunos), trabalhando/operando juntos em um processo educacional, qualquer que seja a pedagogia utilizada. A diferença de papéis entre professor e aluno, por si só já determina uma ordem hierárquica nas relações que se estabelecem entre eles. Tal ordem poderá desenvolver-se em moldes autoritários ou democráticos (com a participação efetiva dos alunos). Nos moldes democráticos, há maior acolhimento de utilização de uma metodologia de ensino-aprendizagem colaborativo/comunicacional.

É fundamental, pois, esclarecer que o ensino on-line não é necessariamente colaborativo, conforme afirma, Teles (2000), entre outros. O professor é o responsável pela

\footnotetext{
${ }^{66}$ THE OFFICE OF INSTRUCTIONAL CONSULTATION (OIC). Differences between Collaborative and Cooperative Learning. Disponível em: 〈http://www.id.ucsb.edu/IC/index.html〉. Acesso em: 04 mar. 2002.
} 
adoção ou não de uma metodologia de ensino-aprendizagem colaborativo/comunicacional em sua proposta de curso.

Tu \& Corry (2001) apontam para o fato de que a aprendizagem colaborativa é um método de ensino em que os alunos, visando atingir um objetivo comum, são responsáveis pela sua própria aprendizagem bem como dos demais integrantes do pequeno grupo que formam. Sendo assim, o sucesso de um aluno propicia o sucesso de outros.

Acreditando que a aprendizagem colaborativa, onde as trocas de experiências e conhecimentos entre os sujeitos do processo educacional trazem contribuições importantes para a formação desses sujeitos, resta saber quais são as características principais desse tipo de aprendizagem para que se possa implementá-la da maneira mais plena possível.

Tinzmann et al. (1990) apontam quatro características essenciais de uma sala de aula colaborativa: o compartilhamento do conhecimento entre professor e alunos, o compartilhamento da autoridade entre eles, a função do professor como mediador do processo de aprendizagem, e a constituição de grupos heterogêneos de alunos. Com relação a este último item, afirmam os autores que todos e quaisquer alunos devem ter a oportunidade de dar sua contribuição para o grupo. Qualquer tipo de segregação é visto como fator de empobrecimento da colaboração.

As características de uma sala de aula colaborativa também podem ser produzidas e/ou realizadas em um ambiente de aprendizagem colaborativa on-line. Ekhaml (1999) argumenta que a aprendizagem colaborativa on-line contribui não só para aumentar a motivação dos alunos, mas também para eliminar a sensação de isolamento neste tipo de aprendizagem e ampliar a atmosfera da comunidade on-line (que, conforme exposto anteriormente, depende da articulação entre todos os membros integrantes do grupo em questão). 
$\mathrm{Na}$ aprendizagem colaborativa, a vivência da aprendizagem em grupo é destacada. Estudiosos do trabalho em grupo como Souza \& Saito (1999), apontam para o fato de o aluno que aprende a trabalhar em grupo ${ }^{67}$ e compartilhar pontos de vista diferentes aumenta sua experiência e se torna mais motivado.

Uma prática pedagógica colaborativa implica em relações entre alunos e entre alunos e professores com o conhecimento, ultrapassando modelos bi-polarizados de ensino: ou centrado no professor, ou no aluno. A esse respeito, Penteado (2002, p. 34, grifo do autor) afirma que:

Será por meio das decisões didático-pedagógicas - definição de objetivos, seleção de conteúdos, traçado de procedimentos, elaboração de avaliação - vividas ao longo de um planejamento processual, em oposição a um planejamento pontual/formal, fixado num momento antecedente à vivência do processo educativo, que se promoverá a substituição do processo de dominação/subordinação, autoritário e pouco produtivo do modelo tradicional de ensino pelo de comunicação escolar colaborativo e construtivo.

O significado da aprendizagem colaborativa é mencionado por Chickering \&

Ehrmann (1997) da seguinte forma:

O aprendizado é aprimorado quando é mais um esforço de grupo do que uma corrida solitária. O bom aprendizado, como o bom trabalho, é colaborativo e social, não competitivo e isolador. Trabalhar com os outros geralmente aumenta o envolvimento no aprendizado. Compartilhar idéias e responder às reações dos outros melhora o pensamento e aprofunda a compreensão. ${ }^{6}$

Visão semelhante é apresentada por Collins (1998, apud LUKOWIECKI, 1999):

\footnotetext{
${ }^{67}$ Vale ressaltar que os autores apenas mencionam a relevância do trabalho em grupo sem esclarecerem se este se dá de forma cooperativa ou colaborativa.

${ }^{68}$ No original: "Learning is enhanced when it is more like a team effort than a solo race. Good learning, like good work, is collaborative and social, not competitive and isolated. Working with others often increases involvement in learning. Sharing one's own ideas and responding to others' reactions improves thinking and deepens understanding."
} 
[...] ninguém é uma ilha e que não há um projeto tão simples que uma só pessoa possa realizar sozinha, e que aprender com os outros, reformulando o conhecimento a partir da crítica do outro, é importante para o fortalecimento das habilidades de comunicação e raciocínio.

A despeito da importância das colocações de Chickering \& Ehrmann, assim como as de Collins, reflexões sobre questões de fundamental relevância se fazem necessárias: as dificuldades do ser humano em aceitar suas limitações e inexperiências frente ao outro; em receber as críticas do outro e reconhecer nelas a procedência dos argumentos e a possibilidade de que a partir dessas críticas é possível avançar em seus próprios conhecimentos, e em reconhecer no outro um aliado (co-laborador) com quem se pode dialogar para crescimento mútuo e aprimoramento de cada um como cidadão e como ser humano, sem riscos sociais.

Tais reflexões se vinculam à necessidade de confrontar o professor com propostas educacionais que encorajem e guiem os alunos na descoberta das competências do outro e em transformar o processo competitivo (ainda presente na cultura educacional da atualidade) em processo colaborativo, produtivo e satisfatório para o grupo.

Em palestra proferida no SESC, Vila Mariana em 2002 e que resultou em artigo publicado na Internet ${ }^{69}$, Lévy afirma que "a troca de idéias, a cooperação intelectual é algo importante para o desenvolvimento cultural e social”. Também em Lévy \& Authier (2000, p. 102), a importância do compartilhamento do conhecimento é abordada quando os autores postulam que "o que ignoro é antes de tudo o que o outro sabe".

Referência a esse tema também é encontrada em Lévy (1998a, p.27) quando o autor afirma que:

69 LEVY, P. As Inteligências Coletivas. Palestra proferida no SESC, Vila Mariana, São Paulo, em ago. de 2002. Disponível em: 〈http://www.sescsp.com.br/sesc/hotsites/pierre_levy/Conferencia.doc〉. Acesso em: 10 set. 2002. 
Toda atividade, todo ato de comunicação, toda relação humana implica um aprendizado. Pelas competências e conhecimentos que envolve, um percurso de vida pode alimentar um circuito de troca, alimentar uma sociabilidade de saber. [...]

O outro não é um ser assustador, ameaçador: como eu, ele ignora bastante e domina alguns conhecimentos. Mas como nossas zonas de inexperiência não se justapõem ele representa uma fonte de enriquecimento de meus próprios saberes. Ele pode aumentar meu potencial de ser, e tanto mais quanto mais diferir de mim. Poderei associar minhas competências às suas, de tal modo que atuemos melhor juntos do que separado.

Apesar da pertinência do pensamento dos autores, sobre a importância das trocas de saberes entre os indivíduos, não é fácil não ver no outro um ser não ameaçador. Ter nossos valores, atos e condutas pessoais expostos e avaliados por um outro indivíduo não é algo simples de ser feito do ponto de vista psicológico, em sociedades competitivas como as organizadas no modo capitalista de produção da atualidade, agora exacerbado pelo processo de globalização econômica, e nas quais, de modo geral, grassa o desemprego.

O atual contexto sócio-econômico, filosófico, político, educacional e tecnológico, por sua natureza competitiva, requer que os indivíduos aprendam a se organizar em grupos e a trabalhar conjuntamente, mas as soluções pretendidas são de grupos de interesses, que em geral, não visam questões de humanidade.

Simultaneamente a este contexto, e mesmo como decorrência dele, os problemas econômicos, educacionais e culturais vêm provocando um certo despertar, embora ainda incipiente, sobre o esgotamento deste modelo organizatório, e um certo vislumbre de que em processos colaborativos e solidários é que se poderá encontrar a superação dos problemas atuais.

Esse modelo educacional deve destacar a participação conjunta dos sujeitos da aprendizagem, realizada nas trocas constantes entre esses sujeitos e com os conhecimentos 
já elaborados, através de uma rede de relações sócio-pedagógicas que envolve a todos. Implica, pois, em desenvolver posicionamentos; aprender a "ouvir" e aquilatar o ponto de vista do outro e reavaliar seus próprios posicionamentos, modificando-os quando convencidos por argumentos procedentes, etc. Tais condutas no trato com o conhecimento, entre as pessoas, são as condutas exigidas pelo projeto de construção de uma sociedade democrática, conforme trata Morin (2000).

No caso da sociedade brasileira, de passado colonial/patriarcal "aguardar e seguir a ordem proposta pelo patriarca é a regra que norteia o comportamento político das pessoas [...] [e encontra correspondência] no modelo tradicional de ensino que forma o homem para acatar e cumprir ordens". (PENTEADO, 2002, p.35). A realização do modelo de sociedade democrática que almejamos, passa, então, necessariamente pela aprendizagem de condutas preconizadas pela pedagogia da comunicação, cujos valores são também trabalhados pelo modelo de ensino colaborativo.

O quadro proposto por Penteado (2002, p. 35) e apresentado a seguir, destaca, embora de forma não exaustiva (conforme colocado pela própria autora), os valores com os quais o modelo de ensino comunicacional trabalha (em oposição ao modelo tradicional de ensino) e que são os que servem de suporte, ou de viabilização do modelo de ensino que se pretende colaborativo. 
Quadro 1 - Quadro de Valores

\begin{tabular}{|l|}
\hline \multicolumn{1}{|c|}{ MODELO DE ENSINO COMUNICACIONAL } \\
\hline mudança como possibilidade de inovação ou de criação/ iniciativa \\
\hline atuação conjunta \\
\hline reflexão crítico /construtiva \\
\hline espírito construtivo, inventividade, criatividade \\
\hline espírito de equipe \\
\hline colaboração \\
\hline $\begin{array}{l}\text { boa capacidade de relacionamento com pessoas, e de comunicação, de modo a conquistar a adesão pela } \\
\text { razão }\end{array}$ \\
\hline alteridade (capacidade de levar em consideração o outro em suas atuaçães), solidariedade \\
\hline autonomia \\
\hline co-responsabilização \\
\hline comprometimento com a atuação e seus resultados \\
\hline partilha do poder \\
\hline $\begin{array}{l}\text { flexibilidade para rever e reorientar comportamentos, reconhecer pontos de vista mais completos e bem } \\
\text { elaborados do que os próprios, abdicar de pontos de vistas pessoais, em prol de outros melhor elaborados . }\end{array}$ \\
\hline
\end{tabular}

Apesar de vários autores enfatizarem a importância de processos educativos mais inovadores, a busca de novas propostas pedagógicas, que correspondam às expectativas daqueles que vêem a Internet como um meio novo e potencialmente eficaz de incentivar a aprendizagem participativa/colaborativa e de aquisição de conhecimento construída através do compartilhamento de saberes está apenas no início.

Todavia, já se concebe que é através de projetos colaborativos e de outras formas de colaboração que a empatia se manifesta em comunidades de aprendizagem (PREECE, $2004)^{70}$. Portanto, evidencia-se o significado da aprendizagem colaborativa em um curso on-line que vise se tornar uma comunidade desse tipo.

\footnotetext{
70 PREECE, J. Re: empathic communication (query). [mensagem pessoal]. Mensagem recebida por vcqm@uol.com.br em 25 jul. 2004. No original: “[...] we'd like learning communities to be empathic, which could be encouraged by, for example, setting collaborative project and encouraging other forms of collaboration that lead to empathy."
} 


\section{3.- F erramentas digitais: usos pedagógicos}

A oferta e realização de cursos na modalidade on-line, que valorizam a comunicação e interação entre os sujeitos participantes destes cursos, têm se proliferado na atualidade, devido à expansão do uso da Internet e de tecnologias digitais de apoio.

Outro fator que vem contribuindo para esse fim, diz respeito à conscientização, por parte de vários docentes, da importância da comunicação e da interação social no processo de aprendizagem - principalmente por aqueles professores que trabalham com ensino online, e cuja proposta pedagógica prioriza a aprendizagem colaborativa. No meio digital, o processo de comunicação e interação entre os indivíduos só pode se realizar através da utilização de ferramentas específicas criadas com esse propósito.

Novas ferramentas surgem a cada dia, o que torna necessário explorar suas potencialidades, limitações e, principalmente, adequações aos objetivos, ao conteúdo e às propostas metodológicas de um curso on-line a ser implementado. Evita-se, com isso, correr o risco de avaliar as ferramentas apenas em termos técnicos, deixando para segundo plano o caráter pedagógico de sua utilização.

As ferramentas digitais de comunicação foram criadas e implementadas para que os usuários da Internet pudessem se comunicar e interagir entre si, estabelecendo vínculos cognitivos, afetivos, sociais, culturais e comerciais.

Além dos diversos serviços disponibilizados na Web (e-mail, chat e fórum de discussões, entre outros) tem-se observado também, nos últimos anos, o crescente 
surgimento de empresas que divulgam e comercializam seus produtos: plataformas de gerenciamento de cursos na Web, tais como WebCT, Blackboard, etc. ${ }^{71}$

A vantagem dessas plataformas é que integram uma variedade de tecnologias digitais em um único sistema. Outra vantagem é que a sua utilização facilita a implementação e administração de cursos on-line. Além disso, não exige que o professor que deseja fazer uso da plataforma tenha conhecimentos de linguagem de programação.

A interface ${ }^{72}$ desses programas é, geralmente, "amigável” ${ }^{73}$ e sua utilização é, basicamente, intuitiva. Conforme salienta Lévy (1999, p.32-33) “os produtores de programas têm se dedicado à construção de um espaço de trabalho e de comunicação cada vez mais 'transparente'e 'amigável'” .

No que diz respeito ao tipo de comunicação possibilitado - tanto pelos serviços oferecidos pela Internet quanto pelas plataformas de gerenciamento de cursos na Web -, verifica-se que essa comunicação se tornou mais flexível e dinâmica. Ao contrário de se ter apenas a comunicação unidirecional de "um" para "um", ou de "um" para muitos", considerada de baixa interatividade, é possível também a comunicação pluridirecional de "muitos" para "muitos" de alta interatividade.

As interações e comunicações são efetuadas através de ferramentas que podem ser categorizadas de três maneiras distintas: síncronas, assíncronas e híbridas. As ferramentas de comunicação síncrona - como, por exemplo, as ferramentas de chat -, propiciam a comunicação em tempo real. As de comunicação assíncrona - como, por exemplo, o e-mail e fóruns -, permitem que a comunicação se estabeleça, mesmo não estando os interlocutores

\footnotetext{
${ }^{71}$ Um estudo sobre as plataformas de gerenciamento de cursos (Blackboard e Prometheus) é apresentado em Apêndice $\mathrm{K}$ desta pesquisa.

${ }^{72}$ Conjunto de elementos (hardware e software) que propiciam a interação do usuário com a máquina.

${ }^{73}$ O termo "amigável” está sendo usado com o sentido de ser de fácil utilização.
} 
simultaneamente conectados ao sistema de rede. E as híbridas - como, por exemplo, o $\mathrm{ICQ}^{74}$ e o $\mathrm{MOO}^{75}$-, que mesclam os dois tipos de comunicação.

As ferramentas de comunicação síncrona promovem, de maneira imediata, experiências de interação on-line. Atividades, que requerem trabalho colaborativo do grupo e que exigem reflexões, análises, discussões mais detalhadas, questionamentos e colocações de pontos de vista ou de propostas, podem ser mais eficazes se as ferramentas de comunicação utilizadas forem assíncronas.

Uma das características importantes da comunicação assíncrona é que as mensagens recebidas podem ser avaliadas com maior precisão, em um maior espaço de tempo antes de serem respondidas, pois podem requerer estudos, pesquisas e elaborações pessoais.

Outra característica dessas ferramentas assíncronas está no fato de as distâncias entre as mais remotas localidades geográficas do globo e as diferenças de fusos horários dos continentes não se tornarem empecilho para a comunicação em cursos com alunos de diferentes países.

A seguir, apresento uma descrição geral e algumas considerações pedagógicas das ferramentas utilizadas em meu curso básico de inglês on-line.

\footnotetext{
${ }^{74}$ ICQ (do inglês I seek you, eu procuro você) é um programa bastante popular, pois permite a conversação 1 a 1 ou em pequenos grupos, mandar mensagens instantâneas, e o envio e recebimento de arquivos (documentos, imagens e sons). Além disso, permite a seus usuários ver se outros usuários do mesmo programa estão conectados à Internet.

${ }^{75}$ MOO (do inglês Multi-User Domain Object Oriented) é um programa que permite a comunicação em tempo real com outros usuários conectados ao sistema e a manipulação e interação com os objetos nele contidos. Apresenta, entre outras ferramentas assíncronas, o MOOmail (sistema semelhante ao do correio eletrônico). Uma descrição sobre MOOs é apresentada no Apêndice L desta pesquisa.
} 


\section{1.- F erramentas de comunicação assíncrona}

\subsection{1.- E -mail}

Um dos serviços mais utilizados na Internet é o correio eletrônico, também conhecido como e-mail (electronic mail). É um serviço rápido, barato e eficiente que permite - a todos que tenham uma conexão com a Internet -, se comunicar, compartilhar idéias, discutir problemas e trocar informações de cunho pessoal, comercial, profissional ou acadêmico.

O e-mail é utilizado para a troca de mensagens escritas, possibilitando também anexar às mensagens, arquivos em diferentes formatos (imagens, sons, gráficos, vídeos, etc.). $\mathrm{O}$ termo e-mail também se aplica às próprias mensagens enviadas através desse serviço da Internet.

$\mathrm{Na}$ atualidade, a importância do e-mail como instrumento que "abre as portas do mundo" para o indivíduo e o coloca em contato com pessoas dos mais diversos "pontos do planeta" pode ser comprovada através das palavras de Dertouzos (1997, p. 125): “O primeiro sinal de que alguém entrou na Internet e na Web é um ato de orgulho e regozijo: enviar mensagens por correio eletrônico e receber as respostas. O e-mail é uma função básica em todas as infra-estruturas de informação” .

Conforme já colocado anteriormente, o e-mail é uma ferramenta de comunicação assíncrona. É de fácil utilização e permite a interação bidirecional (“um para um”), ou multidirecional ("um para muitos", ou "muitos para um"), o que aumenta a aplicabilidade dessa ferramenta digital. 
Como ferramenta educacional, o e-mail é utilizado para a troca de mensagens pessoais/particulares - sobre os mais variados assuntos -, principalmente entre professor(es) e aluno(s), ou entre os próprios alunos. Essa ferramenta também é freqüentemente usada em cursos na modalidade on-line, e para a elaboração e execução de projetos educacionais disciplinares ou interdisciplinares, nacionais ou internacionais.

Nas plataformas de gerenciamento de cursos na Web é comum encontrar o correio eletrônico embutido no sistema. Nesse caso particular, a ferramenta só pode ser acessada pelos usuários cadastrados nessa plataforma e quando estes estão logados (conectados) ao sistema.

É importante mencionar, entretanto, que plataformas, tais como Blackboard, Prometheus e WebCT (por mim estudadas e/ou utilizadas em disciplinas do Programa de Pós-graduação no qual estou inserida) possibilitam também a configuração do sistema - de tal forma que as mensagens, ao invés de ficarem arquivadas no programa -, podem ser enviadas diretamente para o endereço de e-mail do usuário na Internet. A vantagem dessa configuração é que o receptor (destinatário) pode ler a mensagem sem ter que se conectar à plataforma.

As mensagens de $e$-mail não são, em geral, muito longas. Limitam-se a dois ou três parágrafos com orações curtas e períodos simples. A linguagem usada é normalmente concisa e informal.

É fundamental, entretanto, que a mensagem de e-mail seja clara e objetiva, evitando, assim, qualquer tipo de interpretação errônea quanto ao seu real propósito de envio.

Para evitar ambigüidades ou má interpretação de uma mensagem de e-mail pessoal/informal e para atenuar ou suprir a ausência (em um meio escrito) de recursos 
paralinguiísticos, tais como gestos e expressões faciais -, comuns nas conversas presenciais, ou de entonação de voz - usual em conversas pelo telefone -, pode-se fazer uso de emoticons ou smileys ${ }^{76}$.

Os usuários de e-mail também devem estar familiarizados com as netiquettes (regras que devem ser observadas e seguidas na comunicação escrita). Alguns exemplos dessas convenções da escrita eletrônica são:

Não escrever o texto todo em letras maiúsculas, pois isto equivale a gritar;

Não demorar a responder os $e$-mails, pois não responder com brevidade pode parecer desinteresse, descaso e/ou desrespeito;

Separar os parágrafos com linhas em branco para melhor visualização na tela e para facilitar a leitura;

Evitar flame, ou seja, ataque pessoal e abusivo na forma eletrônica;

Destacar e copiar apenas os trechos que se vai comentar e não o texto inteiro da mensagem original.

\subsection{2.- F órum de discussão}

O fórum de discussão é uma ferramenta assíncrona que se assemelha ao $e$-mail, no que tange, por exemplo, a possibilidade de se anexar às mensagens, enviadas ao fórum, vários tipos de arquivos, tais como: gráficos, textos, planilhas, etc.

\footnotetext{
${ }^{76}$ Recursos gráficos que representam expressões faciais, quando olhados com a cabeça inclinada para a esquerda. Esses recursos descrevem as emoções do emissor da mensagem e devem ser utilizados somente em mensagens informais por serem sinais de intimidade.
} 
Através de um mecanismo de busca (por data, autor ou assunto) é possível recuperar mensagens armazenadas no fórum, o que pode vir a facilitar o acompanhamento de discussões e gerar maiores reflexões sobre um dado tema, antes de o participante do grupo opinar sobre o assunto em pauta.

O fórum eletrônico é caracterizado como uma ferramenta de interação "um para muitos" e/ou de "muitos para um", como uma resposta a uma questão ou afirmação feita por um participante do fórum.

Pode ser descrito como um serviço disponível na Internet, bem como uma ferramenta de programas gerenciadores de cursos na Web. Neste último caso, assim como ocorre com qualquer outra ferramenta embutida em uma plataforma -, é acessado somente por pessoas habilitadas ao acesso do sistema.

O fórum de discussão reúne pessoas para discutir assuntos relacionados a um dado tema e são criados e organizados por tópicos e sub-tópicos temáticos apresentados de forma hierarquizada/seqüenciada. Classificam-se comumente em dois tipos: moderados e não moderados. Nos moderados, as contribuições são "filtradas" de acordo com sua relevância e/ou pertinência em relação ao tema, antes de serem disponibilizadas a todos os participantes. Nos fóruns não moderados, todas as mensagens são apresentadas, ao grupo, automaticamente e sem controle, por parte do responsável pelo fórum.

O uso pedagógico do fórum de discussão está, normalmente, vinculado à capacidade lingüística de síntese, argumentação, clareza e objetividade de expressão e de comunicação. Em cursos básicos de língua estrangeira on-line, sua utilização fica mais restrita à comentários simples ou às trocas de idéias entre os participantes.

A respeito do fórum, Kenski (2004) afirma que "é o espaço central da ação na disciplina on-line". E ainda que "tem espaço aberto para a participação de todos 
(democrático)" ${ }^{77}$. As mesmas netiquettes observadas nos e-mails devem também ser observadas e seguidas nos fóruns.

\subsection{3.- Software de comunicação de voz (Wimba Voice Board $)^{78}$}

O Wimba Voice Board é um software de comunicação assíncrona de voz que permite gravar mensagens e ouvi-las quantas vezes se quiser. As mensagens gravadas são disponibilizadas de forma seqüencial, assemelhando-se àquela apresentada nos fóruns de discussão.

O programa pode ser configurado (pelos usuários) para que o sistema os notifique automaticamente via $e$-mail toda vez que novas mensagens são gravadas e disponibilizadas no Wimba Voice Board.

O potencial pedagógico dessa ferramenta está no fato de as mensagens serem de voz, o que é muito útil e pertinente no aprendizado de idiomas. A ferramenta permite que o professor trabalhe com, e/ou, verifique problemas de entonação e de pronúncia, além do desenvolvimento das habilidades de compreensão e expressão orais.

\footnotetext{
77 KENSKI, V. M. Fórum de discussão. [Mensagem número 406, linha temática: “Chat x Fórum”]. Mensagem enviada ao fórum da disciplina de pós-graduação, Ensinando em Ambientes Virtuais I, FEUSP, 2004.

${ }^{78}$ Software produzido por Eurocom Institute, centro de pesquisas em telecomunicações. O endereço de acesso é $<$ http://www.wimba.com>.
} 


\section{2.- F erramentas de comunicação síncrona}

\subsection{1.- Chat}

Conforme mencionado anteriormente, a comunicação possibilitada por meio de ferramentas de comunicação síncrona, como o chat, ocorre em tempo real. Para tal, é necessário que os participantes (usuários) estejam conectados simultaneamente ao mesmo sistema na Internet.

É uma ferramenta de interação "um para um" (bidirecional) ou de "todos para todos" (pluridirecional).

As conversas no chat se realizam geralmente através de frases ou orações curtas. A linguagem do chat é informal e, embora textual (na grande maioria dos casos) pode ser descrita como próxima da fala.

Como as demais ferramentas, anteriormente apresentadas neste item, também o chat pode ser um serviço da Internet, ou integrar uma plataforma gerenciadora de curso na Web.

A possibilidade de arquivamento dos logs (transcrições) das conversas mantidas no chat configura-se como vantajoso instrumento para fins didáticos, uma vez que oferece subsídios para referências futuras e para (re)leitura das "conversas" mantidas.

O uso pedagógico do chat está vinculado ao desenvolvimento das habilidades lingüística e comunicacional e à possibilidade de, em tempo real, se ter a socialização dos membros participantes de um grupo e o compartilhamento de suas idéias. Em Pointers \& 
Clickers ${ }^{79}$ são apontados vários usos pedagógicos para o chat. Dentre eles podem-se citar: a transcrição do chat para prática da língua estrangeira (estrutura gramatical, ortografia ou vocabulário), seu uso para sessões de brainstorming, ou de formação de pequenos grupos (de três a cinco alunos) para trabalhar em um projeto ou discussão de uma questão proposta.

Para que um chat, com fins pedagógicos, possa ser melhor aproveitado é aconselhável que se agende a sessão com antecedência e se envie, por $e$-mail, o "convite" e a temática a todos os participantes. Assegura-se, assim, que todos tenham conhecimento do horário do evento, do(s) assunto(s) a ser(em) trabalhado(s) e, quando necessário for, do(s) material(is) de apoio.

No caso de se querer reunir pessoas de diferentes localidades geográficas e que se encontrem em diferentes fusos horários para participar de sessões de chat torna-se imprescindível o agendamento dessas sessões previamente e com critério a fim de que se encontre um horário pertinente para todos, ou pelo menos, para a grande maioria.

Varvel (2001) em resposta ao $e$-mail desta pesquisadora propõe que se programe mais de uma sessão de chat. Desta forma, não se teria todos os alunos participando do mesmo chat, o que seria difícil de gerenciar ${ }^{80}$.

\footnotetext{
${ }^{79}$ ILLINOIS ON-LINE NETWORK. Chat as a teaching tool. Pointers \& Clickers. Nov. 1999. Disponível em: 〈http://illinois.on-line.uillinois.edu/pointers/>. Acesso em: 23 abr. 2001.

${ }^{80}$ VARVEL, V. Re: chat [mensagem pessoal]. Mensagem recebida por vcqm@uol.com.br em 23 abr. 2001. No original: "[...] I try to hold more than one chat session. This is important also because I wouldn't want all of my students there at the same time as that may become unmangeable. [...]"
} 
A seguir, apresento um quadro das características principais das ferramentas

descritas.

Quadro 2 -Características Principais das Ferramentas Descritas

\begin{tabular}{|c|c|c|c|c|}
\hline $\begin{array}{l}\text { Tecnologia } \\
\text { Digital }\end{array}$ & Modalidade & $\begin{array}{l}\text { Alguns Usos } \\
\text { Pedagógicos }\end{array}$ & $\begin{array}{l}\text { Competências fundamentais } \\
\text { e Domínios necessários }\end{array}$ & $\begin{array}{l}\text { Tipo de } \\
\text { linguagem }\end{array}$ \\
\hline E-mail & Assíncrona & $\begin{array}{l}\text { - Troca de mensagens } \\
\text { entre professor/ aluno } \\
\text { aluno/aluno; } \\
\text { - Cursos na modalidade } \\
\text { on-line; } \\
\text { - Projetos educacionais. }\end{array}$ & $\begin{array}{l}\text { - Lingüística/comunicacional; } \\
\text { - Fluência tecnológica; } \\
\text { - Domínios das netiquettes; } \\
\text { - Conhecimento de recursos } \\
\text { paralingüísticos }{ }^{81} ; \\
\text { - Domínio (pelo menos básico) } \\
\text { de leitura e escrita. }\end{array}$ & Textual \\
\hline Fórum & Assíncrona & $\begin{array}{l}\text { Desenvolvimento da } \\
\text { capacidade de } \\
\text { participação, } \\
\text { compartilhamento de } \\
\text { idéias, de síntese, } \\
\text { argumentação, clareza, } \\
\text { objetividade de expres- } \\
\text { são e comunicação. }\end{array}$ & $\begin{array}{l}\text { - Lingüística/comunicacional; } \\
\text { - Fluência tecnológica; } \\
\text { - Domínio das netiquettes; } \\
\text { - Conhecimento de recursos } \\
\text { paralingüísticos; } \\
\text { - Domínio (pelo menos básico) } \\
\text { de leitura e escrita; } \\
\text { - Domínio da estrutura lógica } \\
\text { dos “threads" (linhas temáticas } \\
\text { apresentadas de forma } \\
\text { hierárquica e seqüencial). }\end{array}$ & Textual \\
\hline $\begin{array}{l}\text { Software de } \\
\text { Comunicação de } \\
\text { Voz (Wimba } \\
\text { Voice Board) }\end{array}$ & Assíncrona & $\begin{array}{l}\text { - Treino e/ou aperfei- } \\
\text { çoamento da habilidade } \\
\text { de expressão e comuni- } \\
\text { cação oral (cursos de } \\
\text { idiomas); } \\
\text { - Compartilhamento de } \\
\text { idéias. }\end{array}$ & $\begin{array}{l}\text { - Expressão e comunicação } \\
\text { oral; } \\
\text { - Fluência tecnológica }\end{array}$ & Oral \\
\hline Chat & Síncrona & $\begin{array}{l}\text { - Desenvolvimento da } \\
\text { habilidade lingüística e } \\
\text { comunicacional; } \\
\text { - Socialização; } \\
\text { - Brainstorming. }\end{array}$ & $\begin{array}{l}\text { - Lingüística/comunicacional; } \\
\text { - Fluência tecnológica; } \\
\text { - Domínio relativo de leitura e } \\
\text { escrita, já que exige agilidade } \\
\text { mental e rapidez de digitação } \\
\text { de frases e/ou orações. }\end{array}$ & $\begin{array}{l}\text { Textual- } \\
\text { próximo da } \\
\text { fala }\end{array}$ \\
\hline
\end{tabular}

${ }^{81}$ Sinais não lingüísticos que permitem interpretar "atitudes" ou "emoções” do falante. 
Quadro 3 -Aplicações Pedagógicas: Semelhanças e Diferenças entre as Ferramentas

\begin{tabular}{|c|c|}
\hline Principais Semelhanças & Principais Diferenças \\
\hline $\begin{array}{l}\text { Todas as ferramentas são utilizadas para } \\
\text { compartilhamento de idéias, desenvolvimento de } \\
\text { habilidades lingüísticas e comunicacionais, e } \\
\text { aprimoramento das competências e habilidades de } \\
\text { leitura e escrita. Exceção: Software de } \\
\text { comunicação de voz que desenvolve habilidades } \\
\text { de comunicação e expressão orais. }\end{array}$ & $\begin{array}{l}\text { E-mail - comunicação mais rápida; } \\
\text { Fórum - desenvolvimento de habilidade } \\
\text { de argumentar, sintetizar, resumir, ter } \\
\text { clareza na conceitualização de termos e } \\
\text { colocações de idéias; } \\
\text {. Software de Comunicação de Voz - } \\
\text { correção e aprimoramento de entonação e de } \\
\text { pronúncia; } \\
\text { Chat - "brainstorming”, socialização. } \\
\text { Requer agilidade mental e rapidez de } \\
\text { digitação; }\end{array}$ \\
\hline
\end{tabular}




\title{
Capítulo II - Cultivo
}

\author{
ou
}

\section{M etodologia da Pesquisa}

"O conhecimento do conhecimento, que comporta a integração do conhecedor em seu conhecimento, deve ser, para a educação, um princípio e uma necessidade permanentes."

(Morin 2000, p. 31).

1.- 0 bjeto de pesquisa e tipo

O objeto desta pesquisa foi um curso experimental de inglês básico on-line para alunos de diferentes países, cuja língua materna não é o inglês. Realizado em uma modalidade ainda nova de ensino-aprendizagem - em ambiente virtual -, e pedagogicamente fundamentado na teoria colaborativa, teve por meta resultar em uma comunidade virtual de aprendizagem. Por tudo isso, requer análises e estudos aprofundados que me proponho a fazer neste trabalho.

Cada etapa do curso proposto é avaliada e re-estruturada, visando aprimoramentos e re-ajustes de seu percurso para sua melhor adequação aos objetivos do mesmo. O que possibilita a construção de um planejamento, de forma processual e pode vir a servir 
melhor o aluno em suas necessidades e expectativas lingüísticas, que também vão se elaborando e re-elaborando ao longo desse caminho.

No desenvolvimento desta proposta, assumo o papel de professora pesquisadora para poder vivenciar (de alguma forma) as facilidades, dificuldades, propriedades, possibilidades e limites da aprendizagem colaborativa/comunicacional decorrentes de um curso livre de inglês em um ambiente virtual na perspectiva pedagógica aqui adotada.

Ao fazer parte do estudo, elaboro, passo a passo, ao longo do mesmo, as iniciativas e condutas, registrando assim o próprio processo de docência, atenta às ocorrências registradas entre professor e alunos e deles entre si, e com o conhecimento básico da língua inglesa durante o curso, já que a perspectiva, aqui adotada, inclui simultaneamente o processo de aprendizagem de ser professor e de ser aluno on-line.

Assumo também o papel de professora para colocar em prática, os fatores que, segundo os pressupostos teóricos estudados, providenciam a evolução de um curso na modalidade on-line em uma comunidade de aprendizagem, e verificar a viabilidade dos mesmos e suas implicações.

A escolha de curso livre on-line se deu pelo fato de se desejar explorar um grau de liberdade mais amplo de acesso ao conhecimento, disponibilizado pela tecnologia. Assim, não se tem uma estrutura rígida de conteúdos a serem seguidos - como nos casos dos cursos institucionalizados-, já que o curso, aqui focalizado, não é oficial e não faz parte da grade curricular escolar. A propósito, Lévy (1999 p. 169) argumenta que “os indivíduos toleram cada vez menos seguir cursos uniformes ou rígidos que não correspondem a suas necessidades reais e à especificidade de seu trajeto de vida.” Ainda segundo este autor, as tecnologias digitais e as redes de comunicação interativa oportunizam "a transição de uma 
educação estritamente institucionalizada (a escola, a universidade) para uma situação de troca generalizada dos saberes [...]” (p. 172)

A opção pelo nível básico se deu aleatoriamente; e o trabalho com as habilidades de leitura e escrita se justifica por serem essas habilidades necessárias no ensinoaprendizagem da língua inglesa, e primordiais para o bom domínio do idioma, mediado por computador, o que confirmei junto a Feenberg $(2004)^{82}$. Disto resulta o oferecimento do curso cujo enfoque linguiístico propõe o trabalho com estruturas básicas da língua inglesa e o desenvolvimento/aprimoramento preliminar dessas habilidades.

Desenvolvo o processo de ensino-aprendizagem com alunos procedentes de diferentes países, cuja língua nativa não é o inglês, ciente de que esta língua é de uso universal. Por isso, o domínio da língua inglesa por qualquer indivíduo se torna, cada vez mais, uma condição sine qua non para seu desenvolvimento acadêmico e profissional, e mais, para lhe conceder o status de cidadão do mundo. Tal argumento encontra respaldo em Morin (2000, p. 105-106) “qualquer concepção do gênero humano significa desenvolvimento conjunto das autonomias individuais, das participações comunitárias e do sentimento de pertencer à espécie humana."

O grande desafio dessa proposta educacional é de agregar em um curso do idioma inglês alunos de diferentes experiências geo-culturais, espacialmente distantes umas das outras. Assim sendo, as contribuições possíveis de intercomunicação entre essas pessoas são possibilitadas pelo ciberespaço. A respeito disso, Lévy (1999, p. 240-241) argumenta que: “ $a$

\footnotetext{
${ }^{82}$ FEENBERG, A. Re: query [mensagem pessoal]. Mensagem recebida por <vcqm@uol.com.br> em 30 maio 2004, às questões por mim formuladas: <1. Would you consider reading and writing the main potentials of CMC? 2. Would communicative teaching approach be appropriate for teaching writing skills in online courses? $>$

"I am pleased to hear from you. It is no trouble at all to answer your questions. I agree with both assertions."
} 
diversidade cultural no ciberespaço será diretamente proporcional ao desenvolvimento ativo e à qualidade das contribuições dos diversos representantes culturais."

A metodologia utilizada para a coleta de dados desta pesquisa e a forma como estes foram analisados, baseia-se nos pressupostos da pesquisa qualitativa, tal como esta é vista por Chizzotti (1991, p. 79):

[...] A abordagem qualitativa parte do fundamento de que há uma relação dinâmica entre o mundo real e o sujeito, uma interdependência viva entre o mundo objetivo e a subjetividade do sujeito. $O$ conhecimento não se reduz a um rol de dados isolados, conectados por uma teoria explicativa; o sujeito-observador é parte integrante do processo de conhecimento e interpreta os fenômenos, atribuindo-lhes um significado.

Na pesquisa qualitativa é

Nas interações sociais, (que) os indivíduos forjam comportamentos antecipados de outrem e agem em razão de comportamentos esperado dos outros (teoria do ator).A pesquisa não pode ser o produto de um observador postado fora das significações que os indivíduos atribuem aos seus atos; deve, pelo contrário, ser o desvelamento do sentido social que os indivíduos constroem em suas interações cotidianas (CHIZZOTTI, 1991, p. 80).

E ainda nesse tipo de pesquisa, o autor considerado nos alerta para o fato de que:

[...] A identificação do problema e sua delimitação pressupõem uma imersão do pesquisador na vida e no contexto, no passado e nas circunstâncias presentes que condicionam o problema. Pressupõem, também, uma partilha prática nas experiências e percepções que os sujeitos possuem desses problemas, para descobrir os fenômenos além de suas aparências imediatas. A delimitação é feita, pois, em campo onde a questão inicial é explicitada, revista e orientada a partir do contexto e das informações das pessoas ou grupos envolvidos nas pesquisas (p. 81).

Por tudo isso se esclarece que o pesquisador, neste tipo de pesquisa, mantém uma conduta participante. 
Sobre a observação participante, o autor afirma que [ela] "é obtida por meio do contato direto do pesquisador com o fenômeno observado, para recolher as ações dos atores em seu contexto natural, a partir de sua perspectiva e seus pontos de vista” (p. 90).

Os procedimentos de pesquisa qualitativa participante aqui adotada se justificam pela natureza exploratória do trabalho sobre fenômeno bastante novo que é o ensino na modalidade on-line.

Contudo, não basta afirmar que a pesquisa é qualitativa, mas ressaltar que este trabalho configura-se em estudo de caso, delimitado no tempo e espaço pelo acompanhamento de um grupo singular. Esta opção metodológica é legitimada pelas colocações de Lüdke \& André (1986, p. 17, grifo do autor):

O estudo de caso é um estudo de um caso, seja ele simples e específico ou complexo e abstrato. O caso é sempre bem delimitado, devendo ter seus contornos claramente definidos no desenrolar do estudo. $O$ caso pode ser similar a outros, mas é ao mesmo tempo distinto, pois tem um interesse próprio, singular.

Outro fator importante apresentado pelas autoras é o fato de que o estudo qualitativo “ [...] é rico em dados descritivos, tem um plano aberto e flexível e focaliza a realidade de forma complexa e contextualizada" (p.18). E mais, que "o estudo de caso ‘qualitativo' ou 'naturalístico' encerra um grande potencial para conhecer e compreender melhor os problemas da escola” (p. 23). Se a afirmação final é válida para a escola entendo-a mais válida ainda para o conhecimento e compreensão desse novo local de ensino-aprendizagem, que é um ambiente virtual.

Além das considerações apresentadas anteriormente, justifica-se a opção por estudo de caso pela preocupação de que a presente pesquisa não se configure apenas em análises e considerações teóricas, mas que possa contribuir com subsídios e reflexões sobre 
ações e intervenções desencadeadas pela educadora/pesquisadora, nesse novo ambiente, interessada em fazer de seus alunos co-responsáveis pelo processo de aprendizagem, e de modo a germinar condições para se criar uma verdadeira comunidade virtual de aprendizagem colaborativa.

Nada será possível generalizar a partir desse conhecimento tácito gerado a partir de um caso pontual. Como nos esclarecem Lüdke \& André (op. cit., p. 23), “o estudo de caso parte do princípio de que o leitor vá usar esse conhecimento tácito para fazer as generalizações e desenvolver novas idéias, novos significados, novas compreensões”. O que me eximirá de elaborar generalizações e simultaneamente exigirá uma cuidadosa circunstancialização do curso em foco, que possibilite ao leitor cotejar as situações de ensino em que estive atuando.

O escopo desta pesquisa não se esgota na análise relacionada ao desenvolvimento da habilidade lingüística dos sujeitos nela envolvidos, uma vez que postula relações colaborativas como facilitadoras da aprendizagem cognitiva e encaminhadora de comunidades virtuais de aprendizagem. Portanto, nesta pesquisa atribui-se à interação humana e à comunicação didático/pedagógica em situação de ensino on-line papel relevante no processo de aprendizagem.

Busca-se, assim, poder alcançar alguns princípios esclarecedores/orientadores: do ensino de inglês "desinstitucionalizado" que promova os processos de aprendizagem colaborativa on-line; de exigências específicas na elaboração de cursos on-line nessa perspectiva pedagógica para não falantes de língua inglesa oriundos de diferentes países - o que remete a questões de pré-requisitos para planejamento do ensino nessas atuações didáticas on-line -; de fatores que propiciam a evolução de um curso na modalidade on-line com enfoque na aprendizagem colaborativa para uma verdadeira comunidade de 
aprendizes. A partir dos resultados aqui obtidos, espera-se poder contribuir com a didática do ensino de língua estrangeira on-line.

2.- Q uestões de pesquisa e hipótese de trabalho

Os dados foram analisados e interpretados segundo a visão teórica que embasa este trabalho e a partir das considerações/observações feitas pelos vários autores, por mim consultados por $e$-mail, no esforço de responder as questões, apresentadas em SEMENTES (Apresentação), e com as quais este trabalho pretende colaborar:

1. Como sensibilizar os alunos para o valor das trocas de experiências e conhecimentos para a aprendizagem, em culturas em que o valor da competição é estimulado em alta freqüência?

2. Como incitar os estudantes para uma relação pessoal mais autêntica e autônoma com o conhecimento?

3. Como desenvolver atitudes individuais e coletivas necessárias para otimizar o aprendizado mais participativo, colaborativo e dinâmico em ambientes virtuais?

4. Como criar uma "cultura" de interação colaborativa entre professor e aluno e destes últimos entre si?

5. É possível que um curso on-line, no qual se consiga fomentar interações, criar e firmar vínculos afetivos e sociais entre indivíduos (que talvez nunca venham a se conhecer/encontrar presencialmente) possa ser um 
‘degrau' importante para que uma comunidade virtual de aprendizagem se desenvolva?

Pretende-se finalmente averiguar a pertinência da hipótese de que a formação, desenvolvimento e manutenção de uma comunidade virtual de aprendizagem, a partir de um curso na modalidade on-line, se apóia no tripé: desejo (motivação intrínseca que leva o indivíduo a querer participar de um grupo de estudo), empatia (partilha do desejo que mantém os membros unidos) e sociabilidade colaborativa/comunicacional (estabelecimento de relações que levam a alimentar e fomentar o desejo).

3.- D escrição do contex to de pesquisa

3.1.- 0 s sujeitos

O curso contou inicialmente com 20 alunos, sendo 8 homens e 12 mulheres, procedentes do grupo Beginner Grammar Writing (BGW).

Tendo sido planejado para uma duração de 2 meses, estendeu-se por 2 anos e meio (de janeiro de 2001 até julho de 2003). Configurou quatro momentos distintos, ao longo dos quais houve uma rotatividade de alunos, com permanência de 3 em todos os períodos.

Optei por analisar apenas o primeiro momento, que teve duração de 7 meses, dada a enorme quantidade de informações de pesquisa oferecida por cada um deles e o 
limite de tempo colocado para a realização dos trabalhos de construção de uma tese de doutorado.

O presente projeto é fruto de minha formação acadêmica em língua inglesa ${ }^{83}$ e da experiência de mais de 20 anos no ensino deste idioma e em projetos interculturais com o uso da tecnologia, o que tem resultado em palestras proferidas sobre o ensino de inglês mediado pelas tecnologias digitais e em produção de artigos sobre a temática ${ }^{84}$.

Na primeira etapa do curso, atuei em conjunto com uma professora de inglês, natural da Argentina e lá residente, de prenome Norma ${ }^{85}$.

A professora Norma também contava com experiência profissional de mais de 20 anos no ensino de inglês para adolescentes e adultos. Na época da coleta de dados, lecionava inglês para adultos e tinha como interesse o ensino on-line por se tratar de uma nova experiência para ela, principalmente em termos de desenvolvimento profissional e de novas perspectivas de mercado de trabalho.

O primeiro contato com a referida professora se deu no dia 10 de dezembro de 2000 através de um e-mail por ela a mim enviado. Nesse $e$-mail, a professora se apresentava de forma bastante sucinta (nome e profissão), expunha o interesse em ministrar cursos on-line e pedia orientação a respeito de planejamento e execução de cursos nessa modalidade. A docente mencionava também que a sugestão de me contatar havia partido de um membro do grupo de coordenação do EFI. Uma vez que Norma havia se candidatado a ser uma

\footnotetext{
${ }^{83}$ Graduação, licenciatura, mestrado e especialização em língua inglesa no Brasil e no exterior.

${ }^{84}$ Ver indicação na Webgrafia.

${ }^{85} \mathrm{O}$ nome completo da professora argentina não é citado, no presente trabalho, uma vez que desconheço seu $e$-mail atual, o que me impossibilita de ter sua anuência para divulgá-lo. Portanto, estarei utilizando apenas o prenome da professora: Norma. Por questões de coerência e ética sempre que nos referirmos a outros participantes da presente pesquisa, adotaremos a conduta de nomeá-los apenas por seus prenomes. No caso da aluna Vera, acrescentei a inicial de seu sobrenome N, para não confundi-la com Vera professora, cuja atuação também é objeto de averiguação desta pesquisa.
} 
professora voluntária junto ao grupo EFI, eu a convidei para me ajudar a ministrar (a quatro mãos) o curso que eu estava para iniciar.

Nossa ação docente conjunta se deu pelo fato de eu querer testar a possibilidade de exercer a docência colaborativa à distância, o que para mim, de modo particular, se configurava como uma prática educacional desafiadora. Quanto à professora Norma o interesse estava na organização de cursos on-line. É importante ressaltar que apesar de o curso ter sido ministrado a quatro mãos, o planejamento metodológico não foi discutido entre nós professoras.

No desenrolar da pesquisa, a professora Norma se concentrou na elaboração de atividades didáticas que eram, então, discutidas por nós em sessões de chat ou submetidas a mim via e-mail para apreciação, comentários e re-estruturação consensual (quando julgávamos necessário).

A mim coube, atuar como coordenadora responsável pelo design do curso; pela administração do ambiente virtual no qual o curso se inseriu; pela orientação dos alunos quanto a problemas técnicos básicos de acesso ao ambiente, e na elaboração da proposta didática e acompanhamento do processo de ensino-aprendizagem, em todas as suas etapas, do planejamento à avaliação.

A demanda pelo curso $B G W$ por mim oferecido foi significativa. 60 nomes faziam parte da lista, que me foi enviada pelo coordenador do EFI, interessados em compor o grupo de alunos. Por se tratar de um curso experimental, optei por oferecê-lo a no máximo 20 alunos, com os quais acreditei poder trabalhar de forma mais eficaz e poder melhor observar as ocorrências peculiares a essa proposta de ensino em ambiente virtual.

Os primeiros 20 alunos que entraram em contato comigo, seguindo os passos indicados para participar do curso, se tornaram membros do grupo. 
Quanto ao nível linguiístico dos estudantes, não se contava com homogeneidade, principalmente pelo fato de os alunos serem classificados como principiantes. Sempre há nesses grupos aqueles que são considerados false beginners ${ }^{86}$. Isso, no entanto, não se configura como problema para a maioria dos professores de língua estrangeira, acostumados a ministrar aulas para grupo de alunos principiantes. E nem para as pedagogias colaborativa e comunicacional adotadas.

A seguir, apresento as tabelas (1 a 5) para caracterização dos alunos integrantes do primeiro momento do curso.

Tabela 1- País de origem dos alunos

\begin{tabular}{|l|l|}
\hline \multicolumn{1}{|c|}{ País } & \\
\hline Argentina & 1 \\
\hline Bulgária & 2 \\
\hline China & 2 \\
\hline Colômbia & 1 \\
\hline Coréia do Sul & 2 \\
\hline Equador & 1 \\
\hline Hungria & 1 \\
\hline Índia & 1 \\
\hline Ítália & 1 \\
\hline Malásia & 1 \\
\hline México & 1 \\
\hline Polônia & 2 \\
\hline República Checa & 1 \\
\hline Romênia & 2 \\
\hline Rússia & \\
\hline
\end{tabular}

\footnotetext{
${ }^{86}$ False beginner é um termo que se contrapõe a true beginner (verdadeiro principiante no idioma).
} 
$50 \%$ dos alunos do grupo era procedente do continente europeu, $30 \%$ do continente asiático, e 20\% do continente americano (América Latina).

\section{Tabela 2- Grau de escolaridade}

\begin{tabular}{|c|c|}
\hline Escolaridade & Quantidade $(=20)$ \\
\hline Superior & 16 \\
\hline Médio & 2 \\
\hline Não respondeu & 2 \\
\hline
\end{tabular}

Embora não se tenham dados a respeito da idade dos alunos, constata-se que o grupo era formado predominantemente por indivíduos adultos com escolaridade superior.

Na tabela 3, a seguir, incluo a área de estudo dos 16 integrantes do curso on-line que tinham formação universitária.

\section{Tabela 3-Área de estudo}

\begin{tabular}{|c|c|}
\hline Formação Universitária & Quantidade (=16 de 20) \\
\hline Letras - Instituto Universidade de Idiomas & 1 \\
\hline Direito & 4 \\
\hline Médico & 2 \\
\hline Bacharel em Computação & 1 \\
\hline Bacharel em Tecnologia de Artes Gráficas & 1 \\
\hline Bacharel em Artes & 1 \\
\hline Educadora (University of Education) & 3 \\
\hline Médica Veterinária & 1 \\
\hline
\end{tabular}


Os alunos que estudaram engenharia informaram a área de especialização: 2 da química, 1 da eletrônica e 1 da computação.

Quanto à habilidade de uso do computador, obtiveram-se os dados que são mostrados na tabela 4 .

Tabela 4- Habilidade de Uso do Computador

\begin{tabular}{|c|c|}
\hline Habilidade de Uso do Computador & Quantidade (=20) \\
\hline Básico & 3 \\
\hline Entre básico e intermediário & 1 \\
\hline Intermediário & 5 \\
\hline Avançado & 8 \\
\hline Não respondeu & 3 \\
\hline
\end{tabular}

Dos 17 alunos que informaram a respeito de sua habilidade de uso do computador, a maioria declarou ter conhecimento intermediário e avançado nesse quesito.

Finalmente, a tabela 5 mostra como o aluno ficou sabendo a respeito dos cursos oferecidos pelo $E F I$. 
Tabela 5-Conhecimento a respeito dos cursos do EFI

\begin{tabular}{|c|c|}
\hline Como ficou sabendo dos cursos do EFI? & Quantidade (20) \\
\hline Através de outro professor do EFI & 1 \\
\hline Pesquisa na Internet & 10 \\
\hline Através de livro sobre keypal $^{87}$ & 1 \\
\hline Através de - -mail $^{\text {Através da Revista Online Today }}$ & 1 \\
\hline Não respondeu & 5 \\
\hline
\end{tabular}

Pela análise dos dados obtidos, verifica-se que os alunos ficaram sabendo dos cursos oferecidos pelo EFI através da Internet (seja por pesquisa na Web, e-mail, revista eletrônica, professor do EFI). Apenas um declarou ter tomado conhecimento dos cursos através de meio impresso (livro).

3.2.- Cenário (ambiente virtual)

Para realização do curso de inglês básico $B G W$ foi utilizada a plataforma de gerenciamento de curso na Web: Blackboard, que, além de na época ser de livre distribuição e uso gratuito, possibilita disponibilizar todas as informações sobre o curso, sobre os docentes responsáveis pelo mesmo, lista de nomes e e-mails pessoais dos alunos, suas homepages, os avisos, e as atividades do curso. Das ferramentas de comunicação e interação reunidas na plataforma foram utilizadas: o fórum, o e-mail e o chat.

\footnotetext{
${ }^{87} \mathrm{O}$ termo keypal em inglês se refere ao "amigo" com quem se troca mensagens por computador.
} 
4.- C oleta de dados

Os dados da pesquisa foram coletados a partir de observação participante por parte da professora pesquisadora ao longo de todo o primeiro momento do curso aqui analisado e de documentos digitais que fizeram parte dele.

A utilização de documentos digitais como instrumento de pesquisa baseou-se em Lüdke \& André (1986, p. 38): “a análise documental pode constituir numa técnica valiosa de abordagem de dados qualitativos, seja complementando as informações obtidas por outras técnicas, seja desvendando aspectos novos de um tema ou problema”.

A coleta dos documentos digitais foi realizada de forma diferenciada. Respostas a questionários e as mensagens de e-mail foram salvos em disquete e arquivados, sendo que estas últimas, em duas pastas distintas: tutor e group. As atividades, ou seja, as provocações didáticas apresentadas pelas professoras, foram armazenadas nas pastas criadas na área de Assignments do programa Blackboard, e, em seguida, salvas em disquete. As discussões no fórum e as "conversas no chat" foram armazenadas no Blackboard e, posteriormente, impressas pela pesquisadora.

Os questionários constituem instrumentos de pesquisa elaborados para reunir informações sobre os alunos e sobre o curso. As respostas ao questionário inicial (Apêndice A) foram utilizadas tal como foram recebidas para reunir informações que permitiram a caracterização do grupo. Este questionário era composto de 7 perguntas abertas, 5 das quais caracterizam o aluno quanto a seu país de origem; formação; expectativas gerais sobre o curso; fluência tecnológica e modo pelo qual obteve informações a respeito dos cursos do EFI, e foi disponibilizado através da implementação 
de um formulário digital na minha página pessoal na Web. Após o preenchimento do questionário, o aluno clicava no botão Submit (submeter) para que os dados fossem enviados para meu e-mail pessoal. As 2 questões restantes eram para identificação pessoal do aluno.

O questionário (Apêndice E), enviado via e-mail, no final desta primeira etapa do curso, era composto de 6 perguntas abertas. Seu objetivo era o aprimoramento do curso, a partir de levantamento de considerações e observações feitas pelos alunos a respeito do mesmo; explicitar o interesse desses alunos em continuar no grupo, ou seja, de participar do segundo momento do curso.

Assim, serviram para uma avaliação geral sobre a etapa do curso aqui analisada.

Outros documentos compreendem mensagens de e-mail trocadas entre as professoras e entre as professoras e os alunos, e as respostas obtidas dos alunos às provocações didáticas.

As mensagens de e-mails trocadas entre as professoras foram avaliadas para esclarecer a natureza das práticas docentes desenvolvidas, avaliar procedimentos didáticopedagógicos adotados e a sua adequação ou não aos propósitos do curso aqui focalizado, perscrutando relações comunicacionais em uma pedagogia colaborativa realizada entre profissionais on-line.

Já as mensagens de e-mail dos alunos foram utilizadas para extrair informações para aprimoramento do curso, verificar a viabilização das metas pretendidas, bem como a adequação das propostas docentes apresentadas com os suportes teórico-metodológicos adotados. 
As atividades, ou seja, as provocações didáticas apresentadas pelas professoras foram analisadas, tendo-se em vista verificar sua adequação à metodologia adotada no curso.

As sessões de chat realizadas entre as professoras, da mesma forma que as mensagens de e-mail trocadas entre elas, tinham por objetivo avaliar as práticas didáticopedagógicas. A análise desses documentos da pesquisa possibilita verificar a relação das práticas realizadas com os suportes teórico-metodológicos escolhidos.

Finalmente, constituíram instrumentos de coleta de dados os registros de participação dos alunos em sessões de chat e no fórum de discussão.

As sessões de chat, em que os estudantes tomaram parte, e principalmente as discussões no fórum foram analisadas, tendo em vista a caracterização de participação e interação entre os alunos em situação de ensino on-line; a verificação de alguma desenvoltura no manejo de estruturas básicas da língua inglesa ocorrida durante o curso, e de atitudes intra e interpessoais que possam servir de indicadores para desenvolvimento de uma comunidade virtual de aprendizagem colaborativa.

Listando os instrumentos temos:

Observação participante por parte da professora pesquisadora;

Seleção de documentos digitais:

a) questionários respondidos pelos alunos do curso (Apêndice A e Apêndice E);

b) mensagens de e-mail trocadas entre as professoras;

c) mensagens de e-mail enviadas pelos alunos às professoras;

d) atividades, ou seja, provocações didáticas apresentadas pelas professoras, e realizadas pelos alunos;

e) sessões de chat realizadas entre as professoras sobre atividades didáticas 
propostas;

f) registros de participação nas sessões de chat.

g) registros de participação no fórum de discussão.

5.- T ratamento de dados

A partir dos dados obtidos, procedi a uma organização interna dos mesmos, que me permitiu levantar duas categorias para a análise.

A primeira categoria, voltada especificamente para responder às questões vinculadas com o ensino-aprendizagem colaborativo/comunicacional (questões de pesquisa de 1 a 4, apresentadas na página 96), compreende a análise de atividades propostas pelas professoras para serem realizadas pelos alunos, individualmente, em pares ou coletivamente; das respostas obtidas dos alunos a essas solicitações; das atuações conjuntas das professoras, e das aprendizagens docente e discente resultantes.

A segunda categoria foi criada com o propósito de verificar indicadores fundamentais da formação de uma comunidade de aprendizagem a partir do curso on-line e, com isso, tentar responder a questão de pesquisa 5, apresentada na página 96-97, e para poder verificar a hipótese levantada. A partir das características de comunidades virtuais e dos níveis que despertam no indivíduo o desejo de agir e de interagir com o outro apontados pelos diversos autores estudados-, foram considerados elementos fundamentais:

$>$ desejo (motivação e interesses comuns);

indícios de relações empáticas;

comprometimento com o grupo;

tempo de exposição no grupo. 


\section{Capítulo III- Colheita}

\section{ou \\ A E x periência da Proposta E x perimental 0 n-line}

"A sala de aula on-line é um campo de ensinoaprendizagem potencialmente poderoso no qual novas práticas e novos relacionamentos podem criar contribuições significantes para o aprendizado".

$(\text { PALLOFF \& PRATT, 2001, p.25) })^{88}$

Aprender uma língua estrangeira é uma necessidade nos tempos modernos. Diante dessa realidade, crescem os cursos de língua estrangeira na Web e o número de alunos que buscam aprender ou aprimorar-se no conhecimento de um idioma através dessa modalidade de ensino.

O curso por mim proposto, intitulado Beginner Grammar Writing $(B G W)$, inserese entre os vários cursos on-line oferecidos pelo programa $E F I^{89}$. Dois foram os motivos que me levaram a oferecer novamente um curso básico através do EFI: meu vínculo com esse programa já conhecido na Web, o que acarreta a facilidade em contatar novos alunos, e meu interesse em testar um modelo de ensino-aprendizagem on-line diferente daquele

\footnotetext{
${ }^{88}$ No original: "The online classroom is a potentially powerful teaching and learning arena in which new practices and new relationships can make significant contributions to learning".

${ }^{89}$ Informações a respeito do programa EFI, ver notas de rodapé 7 e 8 que se encontram na página 20 em SEMENTES (Apresentação).
} 
experimentado com o $B G W 5$ (meu curso piloto na Web) ${ }^{90}$ em que adotei uma metodologia de ensino individualizado. Também influenciou nessa decisão, a liberdade dada aos professores do EFI para montarem seus cursos de acordo com suas filosofias e seus ideais pedagógicos.

Sendo a proposta do curso $B G W$ criar um ambiente participativo e colaborativo, os conceitos teóricos que deram suporte teórico-metodológico às ações pedagógicas desenvolvidas no curso, fundamentaram-se no Construtivismo, na Pedagogia da Comunicação e nas abordagens comunicativa e colaborativa por mim utilizadas no ensino de inglês como língua estrangeira em cursos presenciais, ao longo de minha carreira profissional. Além desses conceitos, a proposta dos quatro pilares de Delors (1998) ${ }^{91}$ também serviu de aporte por ressaltar atitudes intra e interpessoais trabalhadas nesse curso que reuniu alunos de diferentes culturas e localizações geográficas.

\section{A Experiência Vivida}

1.- C onsideraôes gerais sobre o curso

O curso, em seu primeiro momento de realização (de janeiro a meados de julho de 2001), foi ministrado concomitantemente por duas professoras da área de Língua Inglesa, tendo em vista oferecer maior suporte lingüístico e comunicacional aos alunos.

\footnotetext{
${ }^{90}$ Ver SEMENTES (Apresentação) p. 21.

${ }^{91}$ Ver NUTRIENTES (Capítulo II) p. 62.
} 
Ressaltando a importância da comunicação e interação nos processos de aprendizagem em geral, e em especial na aprendizagem de um recurso de comunicação como é um idioma, tinha-se por objetivos:

dar subsídios para que os alunos pudessem escrever parágrafos curtos;

auxiliar os estudantes no desenvolvimento das habilidades lingüísticas/ comunicacionais através de atividades, sessões de chat e fórum de discussão;

$>$ promover a interação, participação e aprendizagem colaborativa entre os alunos;

$>$ desenvolver autonomia, colaboração, integração social, respeito mútuo, e compreensão das diversidades culturais;

conscientizar os alunos da responsabilidade por sua própria aprendizagem, levando em consideração seus ritmos e estilos;

contribuir com o desenvovimento da aprendizagem individual e grupal.

Ao final do curso, o aluno deveria ser capaz de se expressar por escrito, dentro dos limites de uma comunicação básica no idioma inglês.

Para um melhor aproveitamento do curso, recomendava-se que os alunos:

acessassem o ambiente Blackboard (escolhido para acomodar o curso) pelo menos duas vezes por semana;

tivessem participação ativa no fórum e em sessões de chat previamente agendadas;

checassem o material sugerido como reforço extra, e elaborassem as atividades propostas da forma que lhes era solicitado. 
Considerava-se imprescindível que o estudante enviasse uma mensagem ao professor, comunicando sua ausência por período mais longo do que duas semanas, para que não fosse automaticamente excluído do grupo. Propunha-se, pois, que o aluno se responsabilizasse por sua própria aprendizagem. Ao professor cabia a posição de facilitador e coordenador.

A metodologia de ensino baseou-se principalmente em estratégias didáticas que buscavam enfatizar a construção compartilhada do conhecimento, a interação, colaboração e a troca de experiências entre os sujeitos da aprendizagem. O processo interativo se deu através do $e$-mail pessoal das professoras e do conjunto de ferramentas de comunicação ( $e$ mail, fórum de discussão e chat) do Blackboard, pois conforme propõe Belloni (2001 p. 59):

As técnicas de interação mediatizada criadas pelas redes telemáticas (e-mail, listas de discussão, websites, etc) apresentam grandes vantagens pois permitem combinar a flexibilidade da interação humana (...) com a independência no tempo e no espaço, sem por isso perder velocidade.

Tentou-se mesclar momentos de aprendizagem através de atividades em grupo, realizadas de forma colaborativa ${ }^{92}$, com momentos de aprendizagem através de atividades executadas individualmente ${ }^{93}$, onde atenção especial era dada ao aluno para a resolução de problemas concernentes à e interferentes na aprendizagem da língua estrangeira. Na prática educacional individual é importante facultar ao aluno expor ao professor e/ou aos colegas seus questionamentos de aprendizagem, assegurando-lhes com isso atingir seus objetivos pessoais e intelectuais e desenvolver a autonomia do estudante.

O curso $B G W$ trabalha com leitura de textos de linguagem simples e com a escrita de pequenos parágrafos. Ressalta-se a importância da leitura como: fonte de informação

\footnotetext{
${ }^{92}$ Ver Apêndices F e G

${ }^{93}$ Ver Apêndice $\mathrm{H}$.
} 
sobre um tema de trabalho (na época, escolhido pelo professor) e possibilidade de expansão vocabular. A leitura vinculada a um "propósito afeta a motivação, interesse e forma de ler do leitor” (KNUTSON, 1998). Então ter sido utilizada como recurso complementar/fundamental de apoio e desenvolvimento da habilidade de escrita e de aquisição de fluência lingüística.

A avaliação foi feita processualmente ao longo do curso, tendo em vista a participação dos estudantes no fórum, na interação com os demais integrantes do grupo e na elaboração das tarefas propostas. Essa forma de avaliação é recomendada por autores como André e Passos (2001, p. 182):

Ao acompanhar o processo de aprendizagem dos alunos, o professor tem a possibilidade de acompanhar o seu processo de ensino. [...] A avaliação assume uma característica dinâmica no processo educativo: por um lado, é impulsionadora da aprendizagem do aluno, e, por outro, é promotora da melhoria do ensino.

De forma similar, Penteado (2002) advoga que a avaliação “constitui-se em recurso de pesquisa sobre o ensino" e de didática do professor, o que contribui para o aprimoramento profissional do docente e, conseqüentemente, do ensino.

Por se tratar de um curso experimental em processo, pequenas avaliações ao longo do mesmo e a auto-avaliação da performance do aluno foram solicitadas no decorrer do curso e antes de iniciar o segundo momento. Tal prática tem por finalidade permitir ao professor coletar informações que o levem a identificar e tentar sanar problemas que muitas vezes não são previstos, e o orientem nas condutas docentes subseqüentes. A auto-avaliação foi proposta, imbuída que eu estava, da mesma convicção de Krasilchik (2001, p. 175):

ajudar o aluno a se responsabilizar pelo seu próprio progresso, a estudar pela satisfação de aprender e depender cada vez menos de critérios externos para se conhecer é o resultado que se espera como a melhor evidência de sucesso do processo educativo. 
E de Penteado (2002, p. 122)

Dar voz aos alunos nos permite conhecer os seus diagnósticos, ao mesmo tempo em que se cria a oportunidade para que exercitem desde cedo em suas vidas a comunicação "intra-pessoal" (consigo próprio), a auto-reflexão que pode ser reveladora para cada um de per si, no ato de conhecer-se, além de poder revelar ao professor obstáculos antes insuspeitados, que, se trabalhados poderão ajudar a vencer dificuldades de aprendizagem.

Embora este não seja um curso oficial, há a possibilidade de solicitação de um certificado ou atestado expedido pelo EFI a todo aluno cadastrado em cursos oferecidos pelo programa. No meu caso específico, o aluno se submete a um teste (redação de um pequeno parágrafo) no final do curso para comprovação de seu desenvolvimento lingüístico para recebimento do certificado ou atestado.

\section{2.- V iabilização do curso}

A divulgação do curso foi feita na Web, na página de cursos (Classes) do EFI. Após receber uma lista ${ }^{94}$ com nomes e e-mail de pretensos alunos de nível básico, enviada pelo professor David Winet, realizei os primeiros contatos com esses estudantes no final de 2000.

Para ser aceito no meu curso $B G W$, o estudante era orientado a responder à minha mensagem inicial $^{95}$ (de apresentação da docente e informações gerais), confirmando

\footnotetext{
${ }^{94}$ Atualmente, o próprio aluno, desejoso de se inscrever em um curso on-line, seleciona e contata o professor que ministra o curso no nível que o próprio aluno julga ser ideal para si, consultando a listagem de nomes de professores voluntários e seus respectivos e-mails que se encontram no Website do EFI, no endereço: <http://www.study.com/teacherdirect.html $>$. Também se encontra disponibilizado no Website do EFI um breve questionário de múltipla escolha, intitulado "Is Distance Education for you?", para aqueles que quiserem saber se têm algumas características identificadoras de um aluno on-line.

${ }^{95}$ Date: Mon, 20 Nov 2000 15:57:52 -0200

To:

From: Vera

Subject: EFI Beginners

Dear students,
} 
interesse pelo curso. Em seguida, recebia uma nova mensagem ${ }^{96} \mathrm{com}_{\text {os }}$ pré-requisitos do curso. Caso concordasse com eles, preenchia e me enviava as respostas referentes às questões formuladas no questionário inicial ${ }^{97}$.

Somente os alunos, cujos questionários retornavam respondidos, recebiam nova mensagem ${ }^{98}$ com informações complementares (login e senha, que podiam ser alterados

\footnotetext{
You are receiving this message because you applied for a course at EFI. My name is Vera Mello. I've been a teacher with EFI since 1997. The course will start in about three weeks (that is in the second week of December). In the meantime, I'd like you to fill the form (on my page) telling me your interest in taking an online course and how much time you can spend on the net. My course will require that you do the assignments once a week and that actively participate in the activities. I work with a web-based management program, so everything you do, or I ask you to do will be saved (securely) in the program. Only those registered for the course will have access to the program and materials.

If you have any questions and/or receive this message by mistake, please let me know and I'll immediately remove your name and address from my course list. If you plan to continue your studies with EFI, don't forget to reply to my message.

Thanks. I hope to hear from you soon.

Best, Vera

${ }^{96}$ Para melhor visualização, destaquei, em negrito, no corpo da mensagem, a parte referente aos pré-requisitos do curso.
}

Date: Sat, 25 Nov 2000 11:49:35 -0200

To:

From: Vera

Subject: EFI (first contact)

Dear students,

I got your message and am happy that you are interested in taking the course with me. Remember that the course will officially start on the second week of December. You can work on your own pace, but must commit yourself to me and your classmates. If you want to drop out, for whatever reason you have, please let me know immediately. You will have a week to do your assignments and publish them in my courseware program. The only pre-requisites to take my course are to be actively participating in the course and to work collaboratively. You will be asked several times to comment, suggest and give opinion about each other's pieces of writing. There will be a discussion forum set for this purpose.

I believe that we don't learn in isolation, but working together and sharing our ideas and experiences.

I'll be your facilitator in the learning process.

A last thing, since our course hasn't started yet, and since I haven't given my course url, please reply to this email accepting the rules I established and filling out the questionnaire you find on my homepage. The address is in my signature below.

Have a nice weekend.

Teacher Vera

97 Ver Apêndice A

${ }^{98}$ Date: Sat, 30 Dec 2000 18:28:25 -0200

To:

From: Vera

Subject: EFI News

Dear students,

First Happy New Year to those who celebrate it. Have a wonderful 2001!!!

As promised, here are the instructions for you to access our virtual course. Go to http://coursesites.blackboard.com Login using your first name as user name and password. You can change that later. Click on BGW (beginner grammar course) and then on assignments. You have a week to do the two activities proposed. Please write to me if you have any questions.

You will be having two instructors conducting the course, so have fun!!!

"Talk" to you next week.

Cheers, Vera. 
posteriormente pelo próprio aluno) para acesso ao Blackboard. A decisão de participar ou não do curso cabia ao estudante.

Para a efetivação do curso, ficaram sob minha responsabilidade a elaboração dos questionários (Apêndice A e E), da ementa (Apêndice B), do conteúdo lingüístico a ser trabalhado (Apêndice C), das $F A Q s$ - lista de perguntas mais freqüentes, organizada a partir dos questionamentos dos alunos e as respectivas respostas, que variavam do uso do Blackboard a questões de participação no curso (Apêndice D).

A responsabilidade docente foi compartilhada entre Norma e eu, e estabelecida através de vários contatos por e-mail e sessões de chat.

No primeiro mês e meio de curso, foram constatados entraves por parte dos alunos com relação ao Blackboard, o que leva a inferir que há necessidade de se verificar o "conhecimento" do aluno a respeito do ambiente virtual a ser utilizado e de orientá-lo quanto ao uso do tipo de ambiente escolhido, antes do início efetivo do curso. Como essa precaução não fora tomada, a solução encontrada foi a de tentar minimizar os problemas com a elaboração das respostas às perguntas mais freqüentes $(F A Q s){ }^{99}$, apresentadas pelos alunos e a mim enviadas por e-mail.

O material para acesso pelos alunos encontrava-se disponível nas seguintes áreas: Course Documents, Assessment, Discussion Board, Chat (Browse Archives - arquivos de sessões de chat) e External Links.

Em Course Documents ficavam disponíveis os documentos referentes ao curso, ou seja, a ementa, o conteúdo lingüístico e sua organização, e a lista de perguntas mais freqüentes e suas respectivas respostas (FAQs).

\footnotetext{
${ }^{99}$ Ver Apêndice D.
} 
Um recurso apresentado pelo Blackboard é o de criação de pastas, que no meu curso $B G W$ foram configuradas por temas distintos com o objetivo didático de estruturar, organizar e facilitar a localização de materiais e de atividades propostos ao longo do curso.

A princípio foram criadas quatro pastas: uma com textos de leitura ou links de acesso aos mesmos e exercícios (Reading Assignments); a pasta com exercícios gramaticais e de estrutura lingüística e "chaves de respostas" (Developing Writing Skills); a pasta com atividades voltadas às trocas de informações de cunho meramente pessoal entre os alunos, visando criar vínculos de familiaridade entre eles (Getting Acquainted), e finalmente, a pasta com pequenos testes de avaliação que permitiam ao próprio aluno acompanhar seu desenvolvimento lingüístico (BGW Assessments). Todas essas pastas foram criadas na área denominada Assignments, e cuja tela é mostrada a seguir.

\section{Assignments}

\section{Current Location: Assignments}

\section{Getting Acquainted}

In this folder, you will find the activities we planned for you to meet your cybermates so that you can feel more comfortable and less stressed or shy when asked to do some cooperative work.

\section{Developing Writing Skills (short activities)}

In this folder, you will find brief grammar explanations and short activities that will help you to improve your writing skills. They are all organized from the most recent tasks (in red) to old stuff (in black). The answer key is posted a week later (when the exercise is due) and the title is in blue.

\section{Reading Assignments}

In this folder, you will find reading activities. For every reading you will have a pre-reading activity, the reading itself and a post-reading activity. We highly recommend that you do the assignment and check your answers with a mate/or mates.

\section{BGW Assessments}

In this folder, you will find short quizzes that will help you to keep track of your learning process. Your performance will be automatically graded and saved for later reference. 
Posteriormente, considerei também relevante disponibilizar - na área denominada External Links, uma biblioteca de links, selecionados por ambas as professoras. Foram então criadas pastas distintas, categorizadas conforme sua natureza e especificidade: Course Drills (links para Websites com exercícios complementares de reforço lingüístico); Resources for Course Further Studies (links para páginas, contendo referências adicionais a respeito dos tópicos discutidos no curso) ${ }^{100}$ e Interesting Sites (links para Websites considerados interessantes para o desenvolvimento de habilidades lingüísticas dos aprendizes). Estas três novas pastas se somaram às outras quatro, descritas anteriormente.

O objetivo de criação dessas pastas de links visava apresentar ao aluno (de forma sistematizada) uma gama de possibilidades para estudos individualizados que o ajudassem no seu aprimoramento na língua inglesa, minimizando problemas de cunho gramatical, lexical ou de estruturação de parágrafos.

A tela, a seguir, mostra essas pastas e a descrição em inglês do conteúdo de cada uma delas.

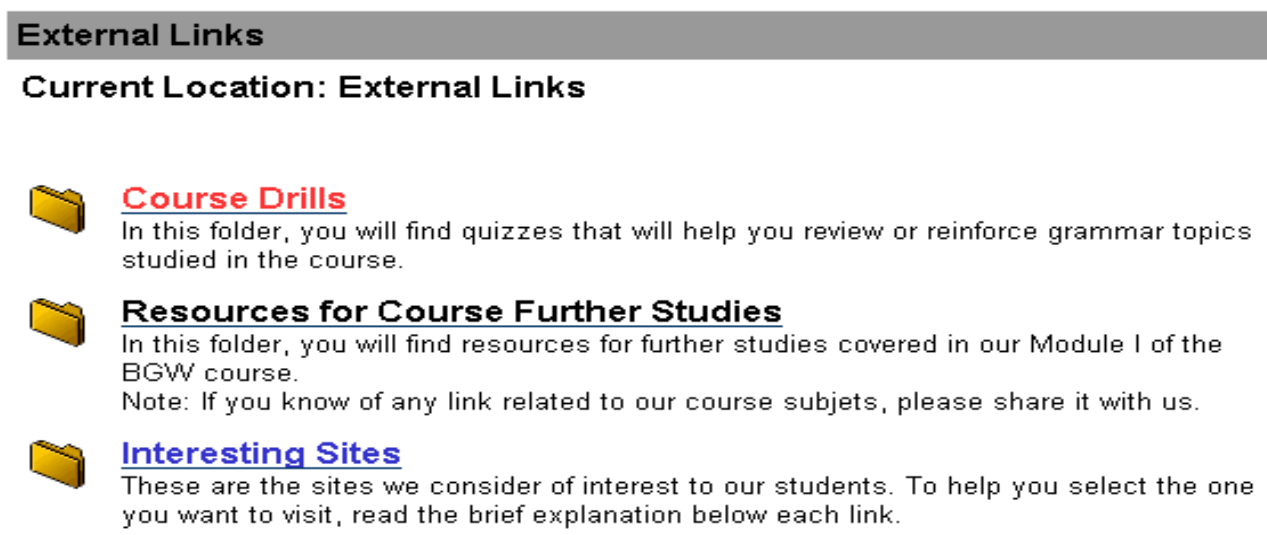

Figura 2 - External Links

\footnotetext{
100 Aos alunos era solicitado que também compartilhassem com o grupo links que conhecessem e que estivessem relacionados aos assuntos tratados no curso. Procuramos, sempre que possível, incentivar a prática colaborativa/comunicacional. Vide nota em Resources for Course Further Studies.
} 
Sendo uma das preocupações lingüísticas a expansão da compreensão e uso de vocábulos por parte dos alunos, disponibilizei na pasta de Reading Assignments um recurso que permite acesso a um dicionário - thesaurus on-line ${ }^{101}$. Sua inclusão, com permissão cedida pelo autor ${ }^{102}$, visava auxiliar o estudante na busca de termos lexicais que não lhe eram familiares - sem ter que deixar o ambiente virtual para utilizar um dicionário impresso.

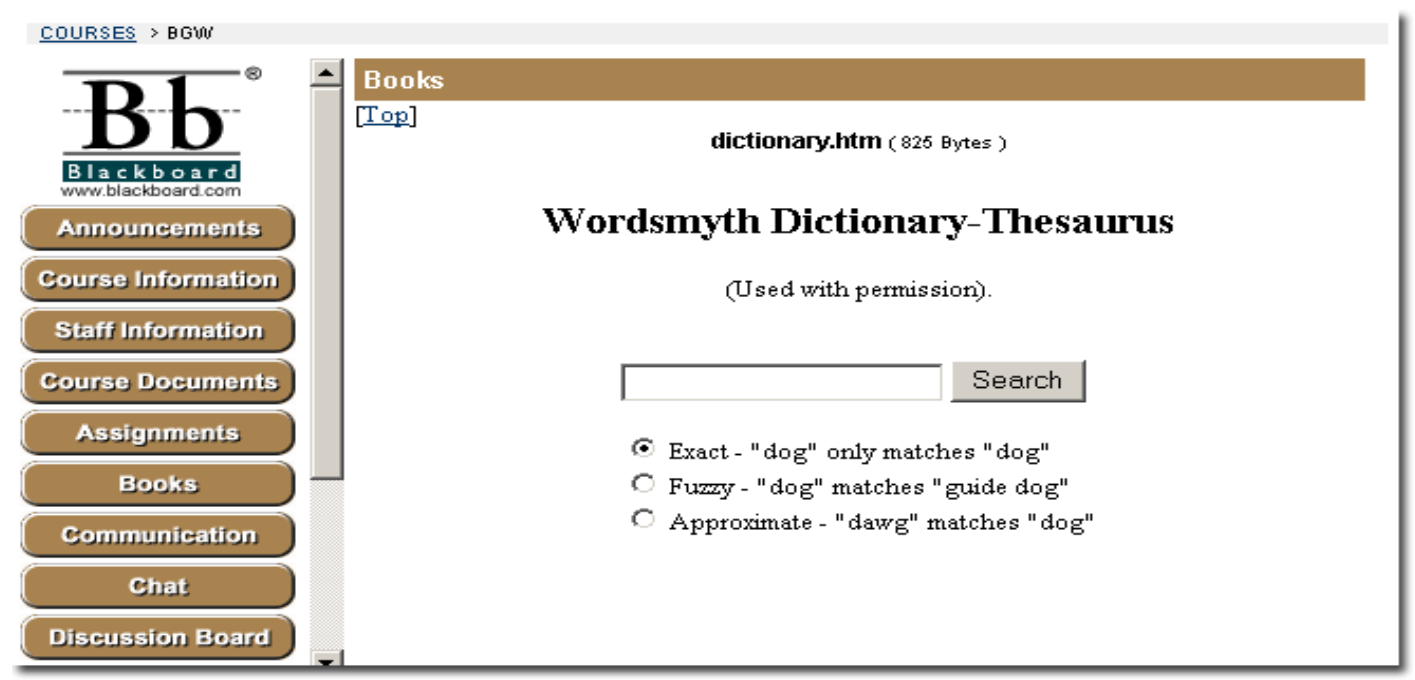

Figura 3 - Dicionário On-line

${ }^{101}$ Digitando-se qualquer palavra na área de inserção de verbetes, selecionando a forma de busca (exata, indistinta ou aproximada) e clicando-se em Search, obtém-se a informação desejada. Por ser tratar de um dicionário e thesaurus, além de se poder verificar o significado de um item lexical, pode-se também saber sinônimos e antônimos de um dado vocábulo.

${ }^{102}$ Autorização de uso: Date: Fri, 3 Sep 1999 23:59:11 -0400

To: vcqm@ruralsp.com.br

From: Bob Parks <bobp@ @op.lightlink.com>

Subject: Wordsmyth

Dear Vera,

Please feel free to use a Wordsmyth query box on any web page. You may also wish to try a "browser button", or put a "floater" on your page. The "Float \& Find" system allows any word on the page to be looked up by selecting the word, and clicking a button. A query box is also included with the floater. Let us know how it works.

Good luck, Bob Parks

Wordsmyth Collaboratory - (607) 257-7895

The best dictionary and integrated thesaurus on the web can be bookmarked at http://www.wordsmyth.net 
No início de maio, resolvi criar pastas também no fórum de discussão, visando à organização de espaços separados para as diferentes atividades/discussões. Assim sendo, Virtual Writing Room seria utilizado para acomodar threads concernentes a opiniões pessoais, reflexões e avaliações pontuais; Virtual Bulletin Board para comentários e sugestões sobre o ambiente virtual; BGW Virtual Cafe para discussões livres; Sharing Doubts para compartilhamento de dúvidas entre os alunos, e Tutor's Virtual Office para problemas técnicos ou questões lingüística a serem direcionados às professoras. A tela, a seguir, ilustra as pastas criadas no fórum com suas respectivas descrições.

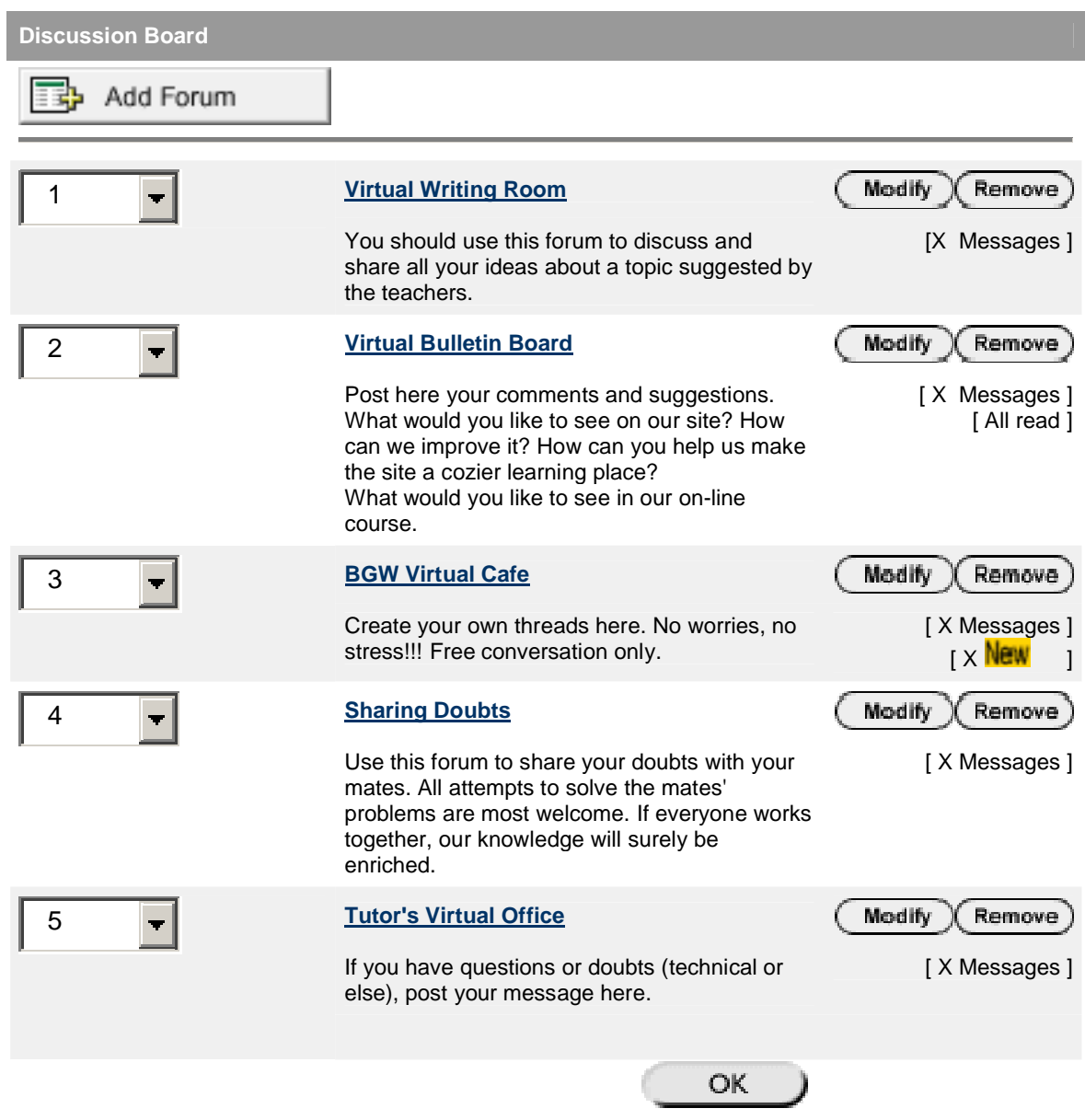

Figura 4 - Pastas do Fórum de discussão 


\section{3.- C onteúdo programátio e Planejamento}

O curso se desenvolveu através de atividades variadas, disponibilizadas aos alunos, em geral, uma vez por semana, aos sábados.

Com o objetivo de sistematizar, organizar e facilitar a visualização da programação mensal das atividades propostas aos alunos, optei por criar documentos (disponibilizados em Course Documents), intitulados Tasks (Checklist), com o tópico, relação das atividades a ele correspondentes com informações a respeito da mesma quando necessário, distribuídas por dia/mês/ano, e a área do Blackboard a ser checada ou utilizada para a realização da atividade ${ }^{103}$. Descartei a possibilidade de uso da ferramenta Task do programa, uma vez que não servia aos meus propósitos, pois permitia apenas a inclusão dos seguintes dados: título da atividade, descrição da mesma e prazo limite para execução.

O programa do curso $B G W$ compreendia: atividades relacionadas à escrita de parágrafos com estruturas básicas da língua inglesa; pequenos textos de leitura e sessões previamente agendadas de chat.

Com relação à escrita foram propostos:

exercícios de gramática (abordando tempos verbais, concordância verbal, orações simples, entre outros) e/ou de estrutura da língua (tais como re-ordenação dos períodos que constituem o parágrafo, e identificação dos elementos sintáticos) para serem feitos individualmente. Por se tratarem de exercícios de respostas únicas eram corrigidos pelos próprios alunos, confrontando as respostas dadas com aquelas fornecidas pelos

\footnotetext{
${ }^{103}$ Os quadros de programação de atividades mensais do curso compõem o Apêndice I.
} 
professores em um documento intitulado Answer Key, e disponibilizado no Blackboard uma semana após o exercício ter sido solicitado;

exercícios de gramática e/ou de estrutura da língua (preencha a lacuna, identifique o erro e re-escreva o período, etc.) para serem feitos individualmente. Tendo esses exercícios respostas variadas, propunha-se que os alunos discutissem em pares suas respostas, antes de enviá-las por e-mail aos professores para correções, breves comentários e/ou explicações;

exercícios de vocabulário e argumentativos, baseados em um texto de leitura. Os alunos eram orientados a responder as questões individualmente e, em seguida, discutir as respostas em duplas (ou trios), antes de enviá-las por e-mail aos professores para comentários e considerações, ou, por vezes, antes de postar as respostas no fórum para serem lidas e apreciadas pelos demais participantes do curso;

* atividades a serem elaboradas conjuntamente por todos os participantes do grupo;

pequenos testes para auto-avaliação individual;

temas, propostos pelos professores e postados no fórum, a respeito dos quais os alunos refletiam e opinavam sobre, davam seu parecer a respeito de colocações feitas por colegas, ou a partir das quais elaboravam seus posicionamentos.

Ressalta-se que embora o curso se apóie em uma abordagem colaborativa/comunicativa, não poderíamos deixar de elaborar exercícios de estrutura lingüística de caráter individual. Não se pode perder de vista que todo trabalho em grupo começa antes dele, em um preparo de cada componente para a atividade grupal, e apresenta resultados que vão além do coletivo, nas repercussões individuais. 
É importante ressaltar também o papel da gramática nesse tipo de curso. Isto porque é preciso chamar atenção do aluno para a importância do uso correto de estruturas da língua estrangeira que necessitam para prevenir comprometimentos na comunicação. Tal procedimento é visto como adequado por Azar (2004) ${ }^{104}$. Segundo a autora, “a abordagem baseada em gramática e a abordagem comunicativa auxiliam uma a outra, não se excluem mutuamente. $O$ ensino explícito de gramática combina bem com abordagens comunicativas”.

A maioria das atividades de leitura foi apresentada no seguinte formato: prereading (para familiarizar o aluno com o vocabulário específico do texto), reading e postreading (para explorar e ampliar o conhecimento obtido através do texto) ${ }^{105}$.

As sessões de chat com os alunos foram realizadas em duas ocasiões distintas. Apesar de se ter enviado um convite a todos os alunos para participar do chat, tem-se que levar em consideração que o grupo era composto por pessoas de diversos países do mundo. Portanto, havia diferenças de fuso horário, dificultando, ou quem sabe, até impossibilitando a participação dos alunos nos encontros em tempo real.

A primeira sessão de chat realizou-se em 3 de março de 2001. O agendamento da sessão foi previamente comunicado aos alunos, em forma de convite para a participação ${ }^{106}$ e colocado na área de avisos (Announcement) do Blackboard. Essa sessão contou apenas

\footnotetext{
104 AZAR, B. In: TESL-L: Teachers of English as a Second Language List. Disponível em <TESL L@CUVYVM.CUNY.EDU>. Acesso em: 09 ago. 2004.

No original: "Grammar-based and communicative approaches are mutually supportive, not mutually exclusive [...] The explicit teaching of grammar blends beautifully with communicative approaches."

${ }^{105}$ Um exemplo é apresentado no Apêndice J.

${ }^{106}$ Dear students,

You are all invited to join us at Virtual Classroom next Saturday, March $3^{\text {rd }}$, at 19:00 GMT. If you cannot meet us at this time, please leave a message at Discussion Board (thread: Chat) suggesting a possible time. See you then :-)

Vera and Norma (EFI teachers)
} 
com as duas professoras e duas alunas: uma da Rússia, e outra da China. Esta última estava residindo, na época, na Alemanha. Três alunas notificaram a impossibilidade de participar da sessão.

A temática abordada versou sobre questões gerais do curso $B G W$, conforme pode ser visto através de um trecho da transcrição da conversa.

Vera> Don't you think you can work with another student using the Net?

Rosy> Please tell me why I didn't find new task.

Norma $>$ Sharing work... you can improve a lot.

Vera> Rosy, sorry. I forgot to answer your question... assignments are uploaded once a week.

Vera $\mathbf{N}>$ The different timetables, different opportunities.

Vera $\mathbf{N}>$ And through EFI could I find a cybermate to collaborate?

Norma $>$ yes great Vera!!! And different people... different and varied ideas!!!

Vera> well, but you are in Russian and there are some students from Russian

Vera $>$ I mean Russia.

Vera $\mathbf{N}>$ I see...But how can I contact with them?

Norma $>$ yes sure!! you can join one of your cybermates and work...

Vera $\mathbf{N}>$ I mean there isn't commun points in our work..

Rosy $>$ Are there other students from China? Mello.

Norma> you have the email in the disccusion board.

Vera $\mathbf{N}>$ We don't know each other..

Vera $>$ There are 20 students in the group. It will be easy to find at least one to work with.

Vera $\mathbf{N}>$ So I can simply mail them?

Norma> Ok so today you met Rosy!!

Rosy> yes, that ture. Hello, Vera (N)

Vera $>$ and she is from China... See?!

Vera N> Sure:) Hi Rosy!

Norma> yes Vera... read what they answer and see what are the ones who coincide or you would like work with.

Rosy> :) Vera (N)

Vera> We will post an announcement asking students to contact each other to do some collaborative work.

Vera $\mathbf{N}>$ It'll be great!

Rosy> that's a good idea, Mello.

Vera N> Rosy, may be we'll collaborate?

Vera> Perhaps you and Rosy can meet some time here at Virtual Classroom and do the work.

Rosy $>$ fine

Norma> This is really Great Rosy and Vera $(\mathbf{N})$ !!!!!!!! great great!! 
Após o término da sessão, solicitou-se que as alunas redigissem juntas um breve comentário sobre suas impressões a respeito do chat, para que os demais alunos pudessem se inteirar da opinião das colegas a esse respeito. Embora o objetivo da tarefa fosse de um trabalho colaborativo, apenas a aluna da Rússia elaborou o comentário, que foi disponibilizado no fórum de discussão do Blackboard, sob o tema: Chat. É interessante ressaltar que a própria aluna da Rússia "cobra" da colega a não participação na elaboração do comentário, o que pode ser verificado através do trecho que destaco em negrito:

\section{Hi all!}

I'm so sorry that I can't tell you about my imressions about the chat before... So I tell you now... It's great! I've met our tutors there. And it's other impression-to talk to them online. You can browse i think the log of the chat. I think that's very important to do these chat sessions.

It gives a possibility to meet other students. Here I've met Rosy! (Where are you, my friend?) And I think we'll collaborate in this project. If you have any questions about the chat-ask me!

P.S. Rosy-mail me!

Sobre essa experiência no chat relatada pela aluna da Rússia, uma única aluna (do México) expressou seu parecer no fórum: compôs uma mensagem, parabenizando a colega da Rússia pela iniciativa de compartilhar com o grupo suas impressões sobre a participação no chat. 
Date: Thu Mar 152001 1:55 pm

Author: Soco

Subject: Re: About Chat

Hi Vera!

Thanks for your comments about the chat. I think that we should collaborate in this sessions too, it gives us the oportunity of practice English and meet our classmates. I hope that I can to attend the next session.

I would like to establish a chat session with someone in this course, but I'm available for 1 hour chat between 17:00pm and 19:40pm (GMT)(Mon-Fri)

This are goods links to check the time zone:

http://www.cnn.com/WEATHER/worldtime/

http://www.timeticker.com/main.htm

Regards,

Soco.

O segundo encontro no chat foi realizado em 24 de março de 2001 e, da mesma forma que o anterior, foi anunciando com antecedência na área de avisos do

Blackboard. ${ }^{107}$ A divulgação dessa sessão de chat foi reforçada através do envio de uma mensagem via $e$-mail ${ }^{108}$ a todos os componentes do grupo.

No convite feito aos alunos para participarem do chat, divulgamos que eles entrevistariam a nós professoras do curso. Entretanto, a entrevista foi cancelada, na última hora, pois a professora Norma teve problemas técnicos de conexão e pode participar muito

${ }^{107}$ Dear students,

We planned a new chat session for you.

Date: March 24th

Time: 7:00 pm GMT

Venue: Virtual Classroom

Don't miss it!!! There won't be popcorn, but it will be fun $(;)$

${ }^{108}$ Date: Thu, 22 Mar 2001 09:24:06 -0500

To: XXX

From: vcqm@ruralsp.com.br

Subject: Chat (session)

Dear students,

Shame on me :-(

It was my fault. Our chat session is on Saturday (March 24th) at 7:00 pm GMT. Please try to come and enjoy some time with XXX and I. Again... no popcorn will be served, but a moment of learning and socializing. Thanks. Vera (EFI teacher) 
pouco tempo do evento. Eu também tive problemas de disconexão do programa por diversas vezes naquele dia, o que me fez decidir por tornar o encontro em um instante de socialização do grupo.

A conversa versou, então, sobre assuntos, tais como: país de origem, hobbies, interesses e aptidões de cada um dos alunos. Apesar da temática ter sido mudada, a sessão se realizou em um clima entusiasmado e participativo.

Na transcrição de um trecho curto destacado aleatoriamente da conversa realizada no chat é possível observar essas características:

William> Colombia is a beautiful country; most of the people is very friendly. The country side is beutiful; you can find rivers to swim

William> Vera, if you come to Cali, I think you will love this city. Zbigniew $>$ I am angler. Colombia must be beautiful country for fishing. Slaveia $>$ Germany is a nice place to work, but Bulgaria is a nice place to live. Zbigniew $>$ and the world is good place to life ;-)

Geza> Maybe Columbia is a good place for me too I like to swimm seeling etc.

Esta sessão de chat teve a participação de seis alunos, oriundos dos seguintes países: Polônia, Hungria, México, Equador, Bulgária e Colômbia. Outros três alunos justificaram a impossibilidade de participar da atividade naquela data.

Além dessa ferramenta de comunicação que integra o ambiente Blackboard foram utilizadas outras duas: o e-mail e o fórum.

O e-mail foi usado, em geral, para receber e responder dúvidas dos alunos; dar instruções; lembrá-los de alguma norma do curso, ou parabenizá-los pela realização de atividades propostas; para o envio de exercícios para as professoras e para o retorno da correção, e para a comunicação do aluno de sua ausência do curso por um determinado 
período. Os exemplos a seguir, escolhidos aleatoriamente, ilustram três dos propósitos citados:

\section{$\underline{\text { Dúvida enviada pelo aluno }}$}

Date: Sun, 18 Feb 2001 15:30:22 -0500

To: Vera

From: William

Subject: Quiz Re arrange sentences

After, I finished this Quiz and I reviewed the word order answer, I have realized that I wrote some sentences in a different order. Because I want to know if there is only a grammatical order, I want to write this sentences here to know your comments:

4-Some people in Central America pleases our policy.

5-The lake is clear and serene.

9-PC drives are useful if you two want to use this disk.

12-When we have breakfast, I always cut Susan a piece of cake.

14-All these sentences are short.

I look forward to hearing from you,

William

\section{$\underline{\text { E-mail de parabenização e notificação de novas atividades }}$}

Date: Mon, 8 Jan 2001 16:56:44 -0500

To:

From: Vera

CC:

Subject: New task and ref. pages

Dear students,

I checked your two tasks and noticed that the majority has already completed them. Congratulations! I'm very proud of the group :-)

There is a new task for you to complete. Access 'Assignments' area to find out what you have to do next. Also, I added some supplemental materials in the 'course docs' area and some in the 'external links' area. Check them out!

P.S. Main problems to be checked/reviewed:
1. Comparatives
2. Relative pronouns
3. Verb tenses
4. Prepositions
5. Conjunctions
6. Punctuation marks.
Best (your EFI teacher) 
$\underline{\text { Lembrete de participação }}^{109}$

Date: Sat. 3 Mar 2001 15:13:15 -0500

To:

From: vcqm@ruralsp.com.br

Subject: Important Note to All Students

Sorry if you have already read/seen this message at Blackboard. Due to the great number of EFI students who want to join our group, we decided to make it clear to all of you that participation is mandatory in the course.

If we do not hear from those who have been too quiet til Friday (March $9^{\text {th }}$ ), these students will automatically be removed from BGW.

Thanks.

Your EFI teachers.

Tem-se o registro de aproximadamente 250 mensagens - sobre diversos temas-, enviadas pelos alunos ao meu endereço de e-mail nesse primeiro momento do curso. Todavia, não se tem dados a respeito do número total de mensagens enviadas pelos alunos, diretamente ao endereço de $e$-mail da professora Norma. Somente no final de maio, me dei conta de lhe solicitar o envio de cópia do e-mail dos alunos a ela enviados, o que foi feito prontamente. Tem-se, então, o registro de 8 mensagens de $e$-mail recebidas pela professora a partir da data da solicitação.

O fórum de discussão foi utilizado basicamente como um espaço de valorização de opiniões pessoais sobre os diversos temas que nós educadoras lançamos para o grupo, de reflexões sobre o desempenho do próprio aluno, e de contribuições para aprimoramento do curso. As transcrições a seguir ilustram essas características.

\footnotetext{
109 Repensando esta prática, creio ter sido mais adequado fazer um "convite" ou uma "provocação" que estimulasse o aluno a dar sua contribuição e participar efetivamente do curso, o que melhor se coaduna com a proposta metodológica de ensino-aprendizagem colaborativo.
} 
Current Forum: English is easy to learn

Date: Wed Jan 32001 2:15 am

Author: Kiaw

Subject: English is tough to learn

In fact, I'm disagree that English is easy to learn especially for those people whose mother tongue is not an English. For me, learning English is tough because since a small child, l'd never spoke a word of English. Besides, when I first study the English subject in primary school, what I'd learnt is just a very basic and there are no actual guidelines for teachers who teach the English. I really need the guideline or advice on how to learn the English for beginner. I wish this online English course can let me experience the formal way on how to learn the English from beginning.

Reply

Current Forum: My first experience at Blackboard

Date: Tue Feb 62001 12:53 pm

Author: Jiri

Subject: The future?

On this time, I'm a bit mazy, as well as Lim. It is the first time I participate on a course like this one and maybe I hurry too much to spread English skills. I am looking forward for future tasks and hope the course will be good for English learning, as well as it will open the possibility to communicate.

A dinâmica de funcionamento do fórum foi determinada pela participação dos alunos e algumas intervenções das professoras para esclarecimentos, ou como reforço e estímulo positivo da atuação participante do aluno. Os dois exemplos a seguir ilustram essas participações das professoras no fórum. 


\section{Esclarecimento de dúvida}

Current Forum: Chat

Date: Sun Mar 112001 3:43 pm

Author: Vera

Subject: Some info about chat sessions

Remove

We will soon be announcing new chat sessions. Don't worry if you could not participate in the first one on March $3^{\text {rd }}$. You can use the Virtual Classroom area to chat with your cybermates. Contact people who live in your time zone area and set a time for chatting. If you don't set a specific time \& date, you will probably not meet anyone there.

\section{Apreciação pela atuação participante do aluno}

Current Forum: How you relate with others

Date: Wed Mar 7 2001 7:48 am

Author: Norma

Subject: Re: How you relate with others

Remove

Soco you sound really nice!!! And you are also working very nice!! Good for you!! Norma

As contribuições feitas pelos estudantes no fórum totalizaram 170 mensagens. Dentre os temas que receberam maior número de mensagens tivemos: English is easy to learn com 21 mensagens e My first experience at Blackboard com 16. As mensagens individuais postadas sob esses dois temas também foram as mais lidas. Essa afirmação baseia-se na marcação automática do número de leituras registradas pelo sistema e disponibilizadas no canto direito superior de cada mensagem (Read X times).

Por se tratar de um curso que não se apoiava em uma estrutura institucionalizada de cursos regulares, conforme mencionado anteriormente, permitiu, mais facilmente, re- 
estruturações e re-adaptações constantes para seu aprimoramento. As dinâmicas e práticas pedagógicas utilizadas foram elaboradas/construídas ao longo do curso, a partir das necessidades encontradas para atingir os objetivos propostos.

Com o intuito, por exemplo, de tentar motivar os alunos a interagirem mais entre si, disponibilizei em minha página pessoal na Web, no final de junho, um link de hipertexto, direcionando o usuário para a página do aplicativo de voz, Wimba, cuja tela é mostrada a seguir ${ }^{110}$.

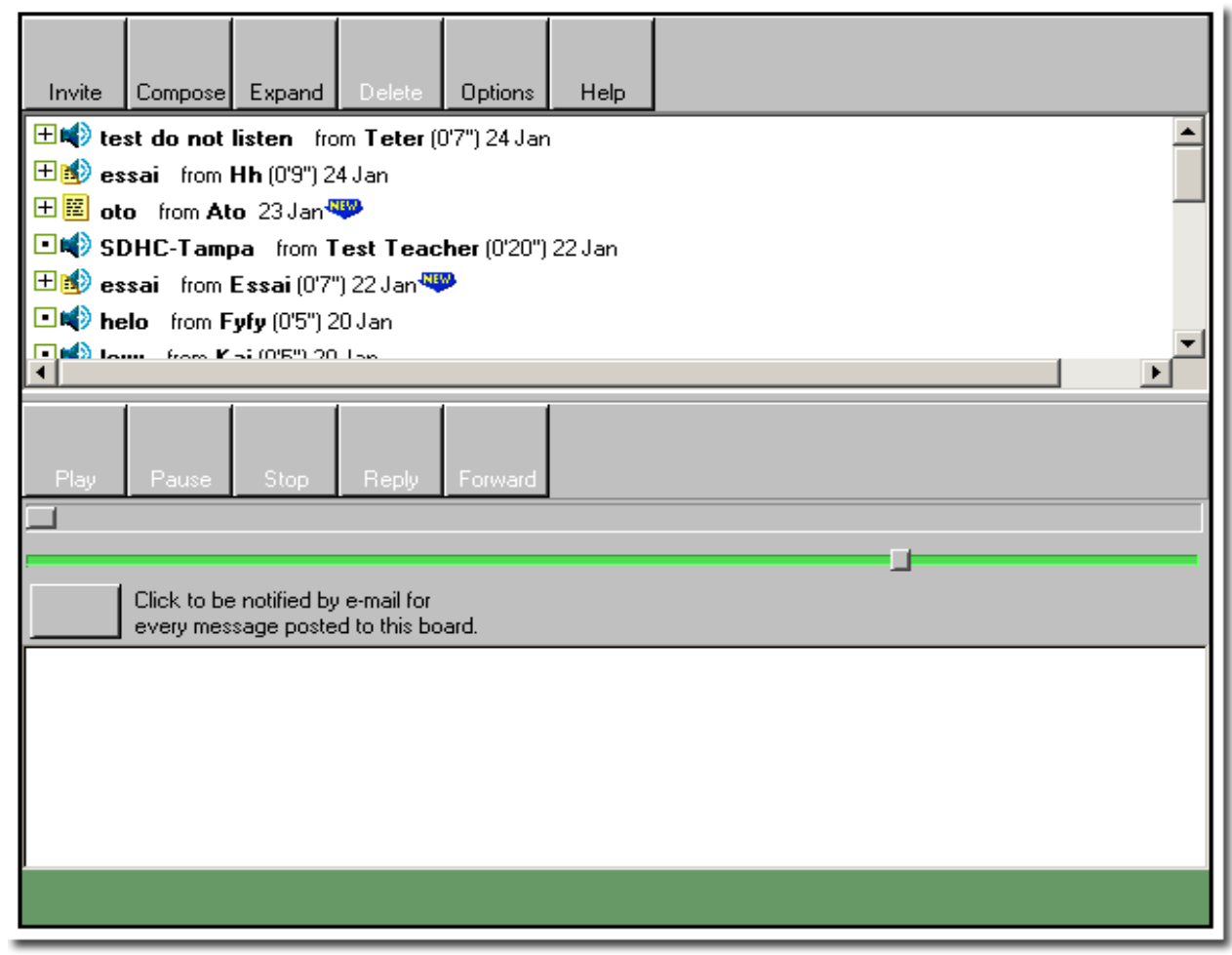

Figura 5 - Programa de comunicação de voz: Wimba

\footnotetext{
${ }^{110}$ Considerações a respeito da utilização do programa de comunicação de voz Wimba são apresentadas em
} A Experiência Interpretada, item 1.1 - Interações colaborativas propostas. 


\section{A Expeniência Interpretada}

Tendo descrito o curso livre de inglês on-line, passo agora a analisá-lo, buscando averiguar os aspectos que permitam identificar em um ambiente virtual a vivência das metodologias colaborativa/comunicacional aqui adotadas, e os indicadores de formação e manutenção de uma comunidade de aprendizagem a partir de um curso livre on-line.

A análise do processo vivido, a partir das duas categorias de análise construídas e a interpretação da experiência como um todo serão realizadas, tendo em consideração a fundamentação teórica dessa pesquisa ${ }^{111}$.

Orientado por uma metodologia de ensino-aprendizagem colaborativo/comunicacional, este estudo exige constante investigação sobre as condutas e intervenções do(s) professor(es) e observação das relações que se estabelecem entre o(s) educador(es) e seus educandos, e destes entre si e com o conhecimento.

Foram considerados importantes para a análise:

- tipos e número de provocações didáticas propostos pelas professoras;

- interações colaborativas realizadas entre as professoras;

- respostas dos alunos às provocações para realização de tarefas colaborativas;

- aprendizagens docente e discente resultantes.

Com base nessas considerações, tentaremos responder às questões de pesquisa vinculadas ao ensino-aprendizagem colaborativo/comunicacional $^{112}$.

\footnotetext{
${ }^{111}$ Ver a respeito NUTRIENTES (Capítulo I).

${ }^{112}$ Ver a respeito SEMENTES (Apresentação).
} 
A seguir, serão discutidos os resultados da análise que visam verificar se o curso $B G W$ veio a se constituir em uma comunidade virtual de aprendizagem. Para tanto, foram considerados fundamentais os seguintes quesitos, referenciados na literatura consultada:

- motivação e interesses comuns;

- indícios de relações empáticas;

- comprometimento com o grupo;

- $\quad$ tempo de exposição no grupo.

Os diferentes itens que compõem cada uma das categorias supra-apresentadas são discutidos separadamente, visando um detalhamento maior a respeito de seus significados no contexto estudado, supostamente mais adequados à manutenção do clima propício ao desenvolvimento/comprometimento necessários à constituição de uma comunidade de aprendizagem.

Todavia, é preciso ressaltar que os resultados de caráter afetivo/relacional mesclamse com os cognitivos de maneira indissociável.

1.- Curso de inglês on-line na perspectiva de uma metodologia de ensino-aprendizagem colaborativo/ comunicacional

A didática colaborativa supõe um relacionamento professor-aluno em que o docente se apresenta como coordenador ${ }^{113}$ do processo de ensino-aprendizagem nas trocas de conhecimento que estabelece com o discente, seja problematizando o conhecimento do

\footnotetext{
${ }^{113}$ Ver NUTRIENTES (Capítulo I) p. 59, onde me posiciono a respeito das diferentes funções exercidas pelo professor.
} 
aluno, seja criando "pontes" entre esse conhecimento e o conhecimento da norma culta, seja apontando caminhos e encorajando os aprendizes, seja provocando e oportunizando a troca de conhecimentos entre os aprendizes. Apóia-se, portanto, a didática colaborativa em uma conduta comunicacional entre professor/aluno/aluno/conhecimento em que o poder do professor se define pela responsabilidade profissional de criar um ambiente educacional/relacional adequado ao desenvolvimento dos sujeitos da educação e de zelar pela qualidade e manutenção desse ambiente comunicacional. Nessas condições, as relações entre os participantes do curso não se organizam em uma hierarquia autoritária e verticalizada, mas orientam-se por relações sócio-pedagógicas de natureza democrática. Na verdade, historicamente, estamos iniciando nossas experiências pedagógicas nessa linha, o que implica em ressaltar que a aprendizagem docente vai decorrendo simultaneamente à do discente nesse processo.

Durante a realização do curso $B G W$ foram elaboradas atividades que tinham por objetivo um tipo de trabalho colaborativo/comunicacional.

$\mathrm{Na}$ tentativa de compreender a natureza dessas atividades, analisamos seus pontos comuns, o que nos permitiu classificá-las em dois grupos, a saber: colaborativas e individuais/colaborativas. Foram consideradas atividades colaborativas aquelas a serem realizadas de forma coletiva, ou seja, todos atuando conjuntamente para sua realização, e atividades individuais/colaborativas aquelas cuja realização individual constituía prérequisito para o trabalho coletivo de partilha e cotejamento das respostas com os outros integrantes do grupo. Além destas foram também propostas atividades individuais com o propósito de providenciar o desenvolvimento lingüístico do aluno sobre aspectos específicos de conhecimentos gramaticais básicos, necessários à comunicação eficiente em língua inglesa. 


\section{1.- Interaçoes colaborativas propostas}

A classificação dessas atividades nos permitiu ter uma visão mais clara a respeito das provocações didáticas de natureza colaborativa que foram lançadas aos alunos.

Os exemplos a seguir ilustram esse tipo de atividade, na ordem em que foram descritas anteriormente.

\section{Colaborativa:}

\section{Error Correction II.}

Here you will find some common errors that should be avoided. If you go back to the explanations of sentence structure and verb tense (present), you will be able to find what the error is/ errors are. Pair with a mate and check if you both agree about the corrections. As always, don't forget to send me a copy of your assignment.

Individual/ Colaborativa:

Welcome Party project.

As of July $15^{\text {th }}$, new students will be joining our group. What about working on a welcome party for them? How about making them feel part of the group from the very beginning?

Discuss possible ways of having a virtual welcome party for the newcomers.

Be creative! Use your imagination!

Each one can be assigned a task that you yourselves propose, and then you can all together come up with a final product. Let's see what you can do by yourselves.

You have 15 days to work on the project and report back to me. I think that's plenty of time, right?

Observando-se os exemplos, verifica-se que no primeiro, a provocação didática de natureza colaborativa é explicitada na verificação da atividade junto a um colega, buscando consenso nos resultados (Pair with a mate and check if you both agree about the corrections). Já no segundo exemplo, a provocação didática de natureza 
individual/colaborativa é explicitada na própria elaboração da proposta que enfatiza a atitude de engajamento dos membros do grupo da qual resulta o produto final (Each one can be assigned a task that you yourselves propose, and then you can all together come up with a final product). Esta atividade foi proposta no início de julho e objetivava a criação de uma festa virtual de boas-vindas a novos alunos. Isto porque se tinha por regra que quando o número de alunos freqüentes no curso se reduzisse à metade ou menos, novos alunos seriam aceitos para compor um novo grupo e iniciar uma nova fase do curso, o que se verificou naquele mês do ano.

Das atividades propostas ao longo do curso e analisadas, 29 compõem a categoria individual; 22 a categoria individual colaborativa, e 5 a colaborativa, perfazendo um total de 56 atividades, o que é mostrado na tabela 6 a seguir.

Tabela 6- Atividades Propostas

\begin{tabular}{|l|l|l|l|}
\hline Atividades individuais & Atividades individuais/colaborativas & Atividades colaborativas & Total \\
\hline 29 & 22 & 5 & 56 \\
\hline
\end{tabular}

O propósito de se verificar o número de atividades colaborativas e de atividades individuais/colaborativas em relação ao número de atividades individuais propostas pelas professoras visa verificar até que ponto a metodologia de ensino-aprendizagem colaborativo/comunicacional orientou a realização do curso.

A diferença entre o número de atividades a serem realizadas individualmente pelos alunos e o número de atividades individuais/colaborativas e de atividades colaborativas propostas no curso não é marcante, conforme evidenciado pela tabela 6. Essa diferença 
numérica se explica pelo fato de tanto eu quanto a professora Norma estarmos nos iniciando em situações de ensino colaborativo na modalidade on-line, refletindo e aprendendo sobre ele ao longo do processo. Isto reflete também no baixo número de provocações didáticas de cunho exclusivamente colaborativas verificado.

Todavia, fica evidenciada a tendência para a elaboração de atividades que viessem a suscitar nos alunos a importância do compartilhamento de conhecimentos e de atitudes colaborativas.

Como esta modalidade de ensino é nova, tanto para docentes quanto para discentes, é possível que uma etapa de adaptação seja necessária ao "cultivo" de um processo comunicacional que estabeleça "pontes" que levem do ensino tradicional de cunho individual à proposta renovada que propusemos.

Na proposição das atividades do curso $B G W$, estivemos atentos à importância da clareza, objetividade e propriedade das instruções dadas aos alunos para a execução das mesmas. Constatou-se que, em geral, as instruções para realização das atividades foram eficazes. Inclusive há registro nos quais o processo de execução da atividade é detalhado passo a passo, como no excerto da atividade individual/colaborativa, apresentada a seguir: 
Verb tenses - Simple present

Part II: Reinforcement exercise.

Write a short paragraph (4 to 5 sentences) telling about your daily routine.

Steps to be followed to do the writing exercises:

a. Do the activities based on verb tenses $(1 \& 2)$ and the short paragraph writing.

b. Send your answers and paragraph to a mate.

c. Each student has to read the answers and the paragraph written by the colleague and is supposed to check whether the verb tense was used correctly in the sentences.

d. Send me a copy of the activity.

e. If nobody contacts you, please let me know immediately.

Entretanto, é preciso registrar a constatação de atividades que não tiveram a aceitação por parte dos alunos. Este é o caso, por exemplo, da atividade, intitulada How Collaborative are you? ${ }^{114}$, em que cada aluno recebia por $e$-mail um trecho de uma estória de aventura. Somente através da troca de e-mail entre eles, questionando a respeito dos trechos recebidos pelos outros colegas, conseguiriam conhecer a estória toda. Esta atividade exigia a participação colaborativa de todos (This time your participation will be a "must" because if you do not participate, you will make the rest lose a piece of the short story). Todavia, nenhum aluno tentou participar, o que gerou certo desconforto em nós professoras, principalmente por acreditarmos que pela curiosidade em conhecer a estória toda, poderíamos suscitar o desejo dos alunos em participar da atividade.

Refletindo a respeito do problema, chegamos a cogitar o fato de talvez não termos dado de forma clara e precisa as instruções para sua realização. Essa desconfiança ficou mais evidenciada através da manifestação de alguns alunos a respeito de como a atividade

${ }^{114}$ Activity: How collaborative are you?

You will read a nice adventurous story: The man who screams at Nightfall (it is a short story about the rapport between people of different races.

Each student receives part of the story. You have to communicate to join the pieces and make the whole of it!!! So check if you have all your cybermates' mail addresses or where to find them!!!! This time your participation will be a "must" because if you do not participate, you will make the rest lose a piece of the short story. So please make your cooperative side pop up!!!:-)) 
deveria se realizar. $\mathrm{O}$ recorte, feito na seguinte mensagem de e-mail trocada entre a professora Norma e eu, ilustra a questão abordada.

Date: Wed, 4 Apr 2001 17:53

To: Norma

From: Vera

Subject: short story

Dear Norma,

I checked the instructions at Blackboard and I guess the students did not understand well what they have to do. You should clarify what they are expected to do. You can see that Soco is waiting to do the activity. Nuvem also contacted me asking what she should do.

[]s

Vera

Na tentativa de conseguir a participação dos alunos na atividade, re-editamos as instruções e prolongamos o prazo para a sua realização. Nem com essa medida, obtivemos êxito. Tal fato mostra que a complexidade do problema é maior do que a cogitada anteriormente, pois, não está vinculada apenas à falta de clareza das instruções.

Uma vez que os alunos não foram questionados quanto aos motivos que os levaram a não participar da atividade, o que somente agora se esclarece como conduta não condizente com a proposta metodológica comunicacional adotada, podemos apenas conjeturar a respeito das razões pelas quais a atividade não foi efetuada: talvez pelo fato de os alunos não terem se interessado por esse tipo de exercício, ou tê-lo achado difícil de realizar, uma vez que exigia a comunicação (por e-mail) entre todos os estudantes. 
É importante registrar também a constatação de uma atividade (individual/colaborativa) que teve a participação apenas de uma aluna (Vera N.). Essa atividade era de utilização do programa de voz (Wimba). Embora também aqui não tenhamos verificado os motivos pelos quais os alunos não se interessaram pela atividade, julgamos serem pelo menos duas as razões que parecem explicar o fato. Primeiramente, eu não explicitei o significado do uso desta ferramenta em um curso cujo objetivo era o desenvolvimento das habilidades de leitura e escrita, e não das habilidades de compreensão e expressão oral. Enviei apenas um e-mail, convidando os alunos a ouvirem minha mensagem de voz e deixarem suas mensagens respostas para serem ouvidas pelos outros membros do grupo. Segundo, não verifiquei se os alunos dispunham, ou não, de microfone e caixas de som, acopladas ao seu computador pessoal, recursos imprescindíveis para o uso do Wimba.

\section{2.- Interações colaborativas realizadas entre as professoras}

A verificação de interações colaborativas realizadas entre as professoras visa fornecer indícios da possibilidade do trabalho docente conjunto on-line na perspectiva metodológica colaborativa/comunicacional.

Para que essa docência fosse possível, uma vez que se realizava à distância, mantivemos constantes contatos através do meio eletrônico (computador/Internet).

A figura 6, a seguir, dá uma visão geral e quantitativa a respeito do total de e-mails trocados entre nós professoras e o número total de e-mails que cada uma de nós enviou para a outra. 


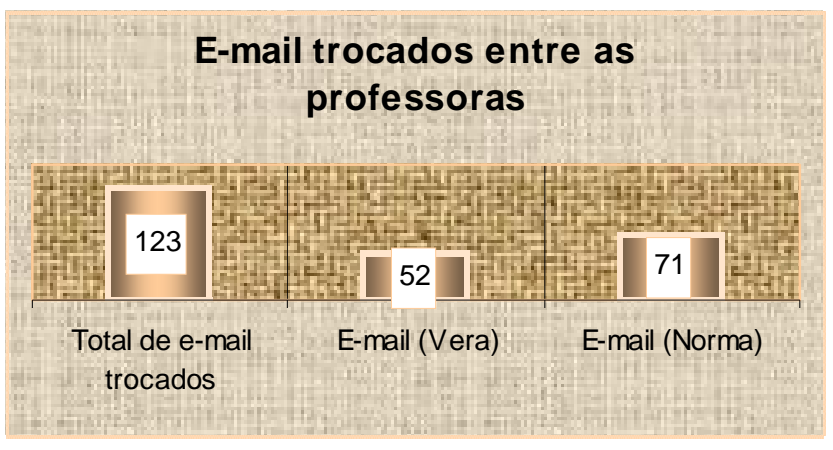

Figura 6 - E-mail trocados entre as professoras

Concomitantemente à troca de e-mail, agendamos sessões de chat para (em tempo real) discutir, principalmente, as atividades do curso. Foram realizadas 17 sessões de chat no ICQ e 1 no Blackboard. Esta última (em 17 de fevereiro de 2001) visava especificamente apresentar a ferramenta de chat do Blackboard para a professora Norma, e com isso viabilizar o agendamento de uma sessão de chat entre nós professoras e os alunos, utilizando essa ferramenta.

A freqüência dos contatos entre a professora Norma e eu, além de facilitar o trabalho colaborativo, também estabeleceu vínculos entre nós que nos permitiram nos expressarmos livremente a respeito das propostas didáticas apresentadas por uma ou pela outra, como se verificam nos seguintes excertos: 


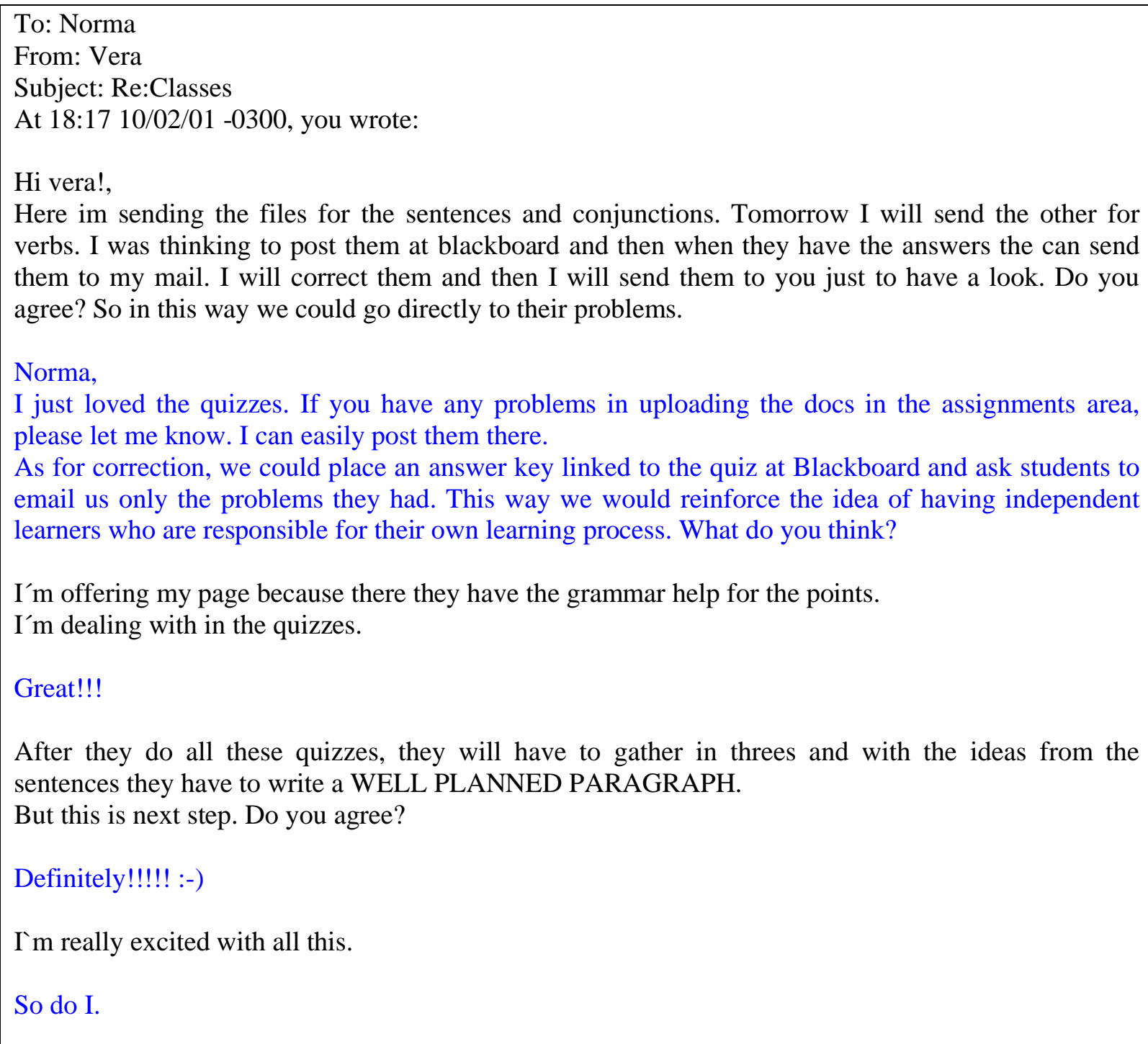


From: "Norma"

To: "Vera"

Subject: RE: news

Vera what you are doing on blackboard is great. Now im sending you the objective for the first unit.. we can call it THE SIMPLE SENTENCE

OBJECTIVE: Write grammatically correct simple sentences

Task nro. 1: a) what do you understand by "Parts of Speech"? b) How many parts of speech are there in the English language?

Vera: They will be able to move forward when then answer to this in the correct way ok? Do you agree?

OK THIS WILL BE THE WAY IN WHICH I THOUGHT TO DO THE COURSE FOCUSING ON

WRITING OK? Then I will send them exercises. Then we will correct together or we will see.

Hugs

Norma

As expressões de incentivo (great, definitely, so do I) bem como de questionamento de opinião (OK?, What do you think?, Do you agree?) encontradas nas mensagens são sinalizadoras de trocas horizontalizadas entre as professoras. Foram fundamentais para que o intercâmbio profissional se estabelecesse apesar de a professora Norma e eu não nos conhecermos pessoalmente.

A experiência em ministrar um curso com a professora Norma foi bastante rica, motivadora e gratificante, porque permitiu experienciar/vivenciar a viabilização de ensino colaborativo à distância, com professores separados geograficamente e também de culturas diferentes. Essa experiência contribui para nosso desenvolvimento profissional e humano, pois como adverte Lévy (1998a, p. 27) "toda atividade, todo ato de comunicação, toda relação humana implica um aprendizado".

O desafio da docência conjunta (principalmente a distância) está na articulação clara, objetiva e sincera entre as professoras. Qualquer mal-entendido que possa vir a ocorrer 
entre as educadoras deve ser de imediato analisado e elucidado para não comprometer todo o processo de ensino.

A ocorrência de situação conflitante na relação interprofissional entre as professoras foi identificada, o que é mostrado no exemplo a seguir, onde a professora Norma questiona a validade de eu querer expor aos alunos os objetivos das atividades didáticas propostas (Regarding the objectives I think it is great to have them in mind. [...] But I don't think it is necessary to notify our students...):

From: "Norma"

To: "Vera"

Subject: RE: Assignments

Date: Mon, 2 Apr 2001 11:40:43 -0300

Dear Vera,

Regarding the objectives I think it is great to have them in mind. This is the first thing I do when I plan a class. But I don't think it is necessary to notify our students. They only have to feel they are LEARNING.

Objectives and thesis or studies we are doing are of our exclusive business Vera. So it is ok that we exchange ideas on how to deliver a class or develop a course but not being to bossy to make them realize they are our guinea pigs. They have just to feel their progress, we can tell them..."This exercise is for you to improve grammar points, or language" but not pointing out OUR objectives, they are not interested in our pedagogy to let them learn... <snip >

O questionamento a respeito do meu procedimento didático foi causa de constrangimento e me fez considerar uma possível resistência, ou desconhecimento de certos princípios da metodologia colaborativa/comunicacional, ou indisposição decorrente de mudanças do comportamento docente da professora Norma, e não compartilhada comigo. Isto porque na perspectiva dessa metodologia, adotada no curso, o ensino é uma relação sócio-pedagógica entre os sujeitos (professores e alunos) nela envolvidos. Portanto, os 
objetivos didáticos pretendidos com o trabalho docente devem ser compartilhados com os alunos, possibilitando com isso integrá-los na situação de ensino da qual fazem parte.

Se procedentes as considerações anteriores é possível supor que os princípios metodológicos adotados estavam talvez mais claros para mim do que para a professora Norma. E a expressão "more academic" adotada por mim naquela ocasião em resposta à professora Norma também revelava ainda imprecisões em minha compreensão. É preciso entender que ambas incursionávamos por novos caminhos educacionais. Desta forma, tais deslizes são indicadores de um percurso de transição.

Julgo também relevante mencionar que a forma pela qual a mensagem foi redigida pela Norma acarretou em mim mal estar. A valorização das palavras LEARNING, OUR escritas em letras maiúsculas e o uso de expressões como - our exclusive business (o que diz respeito somente a nós), bossy (autoritária) e guinea pigs (cobaias) para se referir aos alunos-, foram por mim interpretadas como rudes, ofensivas e agressivas.

A constatação de tal ocorrência exigia esclarecimento urgente, o que resultou no envio da seguinte mensagem para a professora Norma: 
To: Norma

From: Vera

Subject Re: Assignments

Date: Mon, 2 Apr 2001

Dear Norma,

Sorry, I did not want to be bossy, nor did I want to make them our guinea pigs. The idea of setting objectives was only to make them feel that the course was more academic, that it was carefully prepared for them. IMHO, having the objectives set won't interfere negatively in their learning. Also, in an online course I believe everything has to be well structured. If you think I did something wrong, please forgive me. Perhaps I was extra enthusiastic :-(

If you totally disagree upon my initiative, I'll remove all that.

....

I spent two days trying to make the site look better, more attractive, more didactic. I tried to show that they are the ones who can learn by doing... that is what I believe... collaboration, interaction, participation in everything...

I agree that we should lead the course, and I guess we are doing it. Mistakes may happen sometimes... I do feel awful now. I want to do my best for the students, and I'm sure I've always done so. I really do not want to screw things up. Sorry, again.

[ ] $\mathrm{s}$

Vera

Através dessa mensagem, eu me desculpava por qualquer atitude autoritária assumida, tentava esclarecer o motivo pelo qual havia proposto colocar para os alunos o objetivo didático da elaboração da atividade, e expus o sentimento de embaraço no qual me encontrava, buscando transparência em nossas relações profissionais. Ao me posicionar, esperava a resolução da questão conflitante, o que de fato ocorreu com a mensagem (resposta) enviada pela professora Norma. 
From: "Norma"

To: "Vera"

Subject: no mistakes... our page is great!!

Date: Mon, 2 Apr 2001 20:18:23 -0300

Dear Dear Dear Vera!!!!!!,

Please I don`t apologize in this way!!! Im learning from you, you are the expert!!!! So please don`t make me feel bad. Im just exchanging ideas, WE are friends and partners. AND WE ARE BOTH DOING OUR BEST!

We are both mistakes!!!! So please stop to blame on you!!!!

you will make me get mad!!:-)))))))))

I love the job we are doing!!! it is a great job Vera. Only that we have to check all we do!!! and tell all!! in this way we will make a great page!!

WE ARE DOING IT!!! and think that you are the expert!!!! you are the one who is giving the page the professional look!! I don`t know how to do it!!! You have to teach me Vera.

Ok. So don`t change anything in the page!!! just keep on working. The only thing we have to check now is why some students are so quiet!! What can we do for them to react? Do you have any idea Vera? How about inviting them to a chat session on Sat? or probably you have any other idea. LET'S PUT OUR MINDS TOGETHER AND THINK :-)

A BIG BIG KISS

Norma

Com isso, fica evidenciada a preocupação da professora Norma com a resolução do incidente (Please, don't apologize this way!!!, I'm just exchanging ideas) e o seu interesse em continuar atuando no curso (And we are both doing our best; I love the job we are doing;

Let's put our minds together and think).

Através da constatação da ocorrência do fato conflitante e do seu pronto esclarecimento foi possível reverter o quadro de desconforto criado entre as professoras e a retomada do trabalho docente conjunto. Interpretando a ocorrência da situação conflitante, ocorrida entre nós professoras, à luz das assertivas de Lévy (1998c) e de Palloff e Pratt $(1999)^{115}$, podemos afirmar que o conflito contribuiu para o estreitamento das nossas relações pessoais e profissionais e da qualidade do processo de ensino partilhado por nós. De onde se infere que o conflito explicitado e assumido é um sintoma de relações educacionais vivas,

\footnotetext{
${ }^{115}$ Ver NUTRIENTES (Capítulo I).
} 
intencionadas, e não burocráticas. É indicador mesmo da incorporação de uma metodologia comunicacional de ensino, o que implica em transparência nas relações profissionais comprometidas com os objetivos educacionais propostos.

1.3- Respostas dos alunos às provocações didáticas de natureza colaborativa

Os dados apontam para o fato de que, a partir de março de 2001, começaram a surgir as primeiras respostas positivas dos alunos às solicitações de atitudes colaborativas para a execução de atividades, como é mostrado nos excertos a seguir. A interpretação das observações efetuadas é apresentada após cada um dos exemplos.

\section{Exemplo 1}

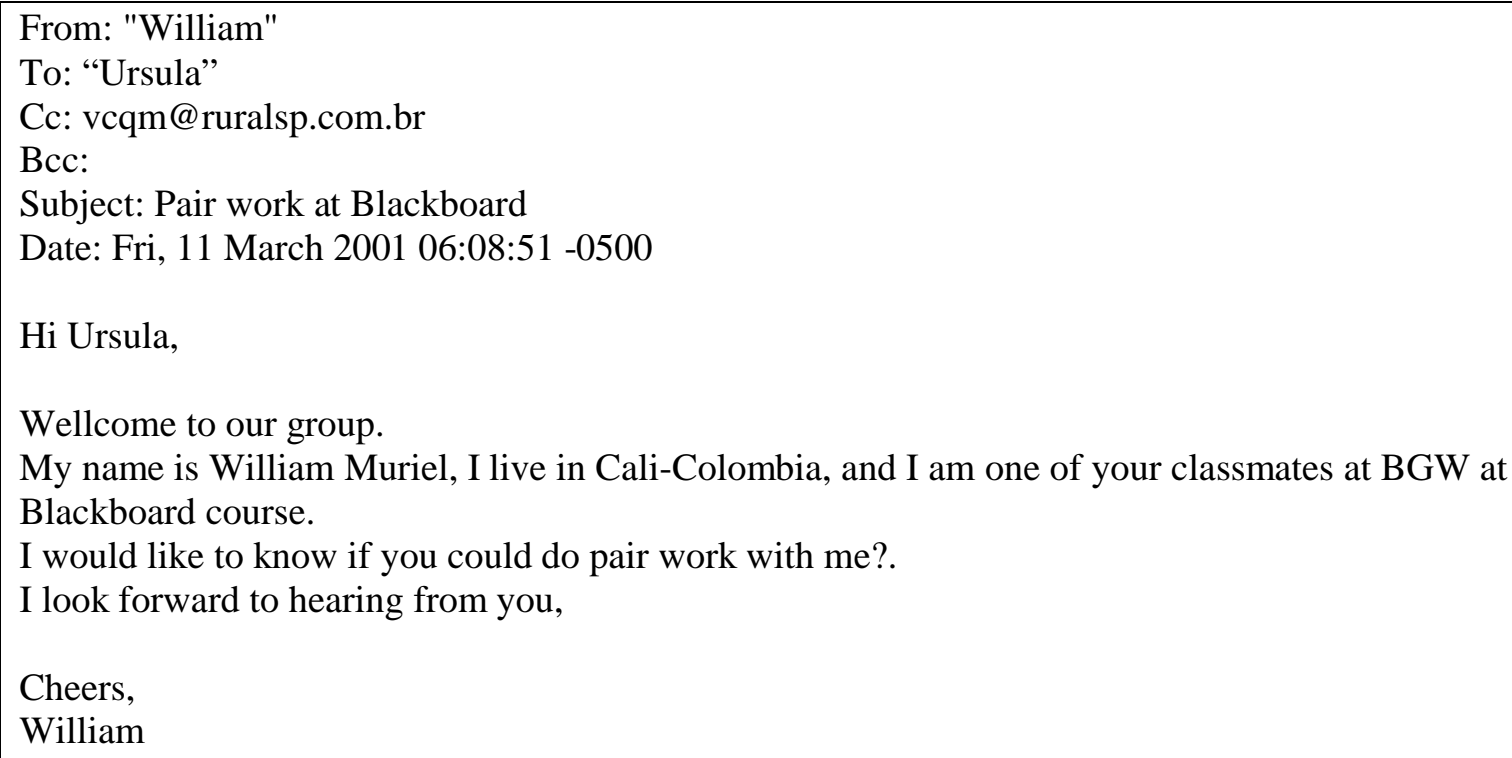


Neste primeiro exemplo, indício de aceitação de solicitação à atitude colaborativa é observado quando o aluno se apresenta à colega e a questiona a respeito da possibilidade de com ele formar dupla para a elaboração de atividades (... could you do pair work with $m e ?)$.

Exemplo $2^{116}$

Current Forum: Virtual Writing Room

Read 13 times

Date: Wed May 92001 9:26 pm

Author: Soco

Subject: Reading Activity 1

Hello!

We are Vanessa and Soco.

The method that we are using to communicate us is by e-mail, to do this activity we sent us approximately 4 or 5 e-mails.

Our comments:

We agree with the text, a community is a group of persons that shares ideas, experiences and interests. We think that the communication is very important between the members of the community, to have a good organization, and in this case, to obtain a successfull online course.

cheers!

No exemplo 2, é interessante observar que a dupla (Vanessa e Soco) não somente apresenta seus comentários a respeito da leitura feita, mas também menciona a forma/método que utilizaram para se comunicar para a realização da atividade (by e-mail) e a quantidade de mensagens trocadas entre elas (4 or 5 e-mail).

${ }^{116}$ Ver Apêndice J em que é apresentada a atividade de leitura. 
Exemplo 3

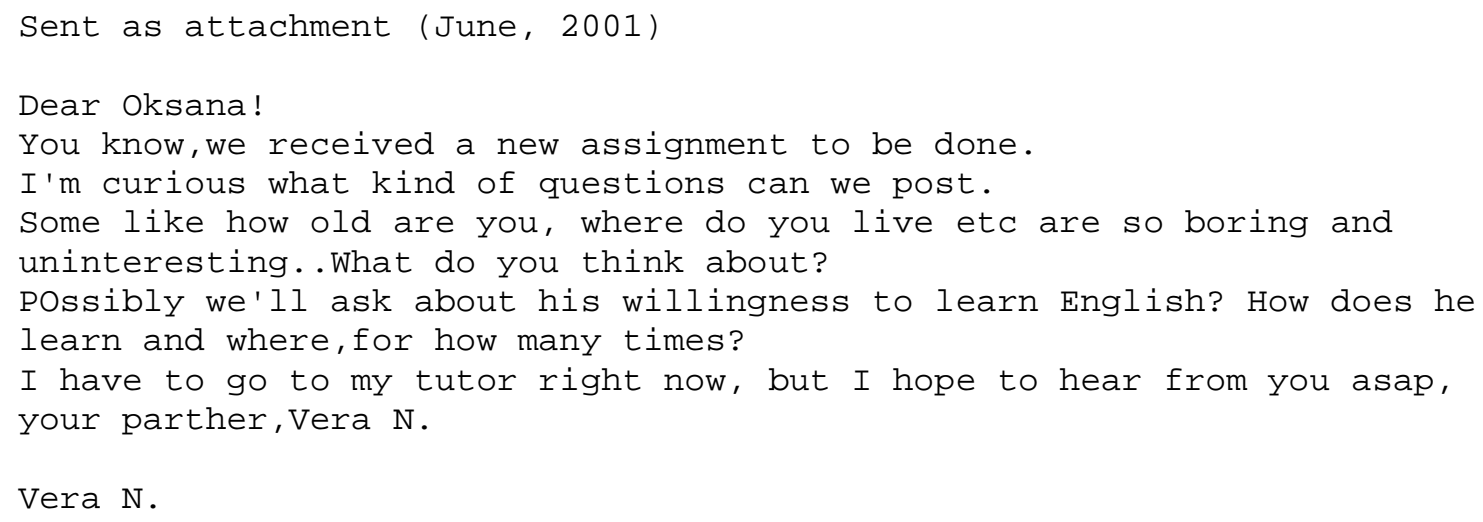

No exemplo 3, indício de atitude colaborativa é explicitado quando Vera N. questiona Oksana a respeito da execução da atividade (I'm curious what kind of questions can we post) e pede opinião a respeito das sugestões apresentadas por Oksana (What do you think about?). Outro indício se verifica através da expectativa de Vera N. de resposta de Oksana o mais brevemente possível (... I hope to hear from you asap, your parther). 
$\underline{\text { Exemplo } 4}$

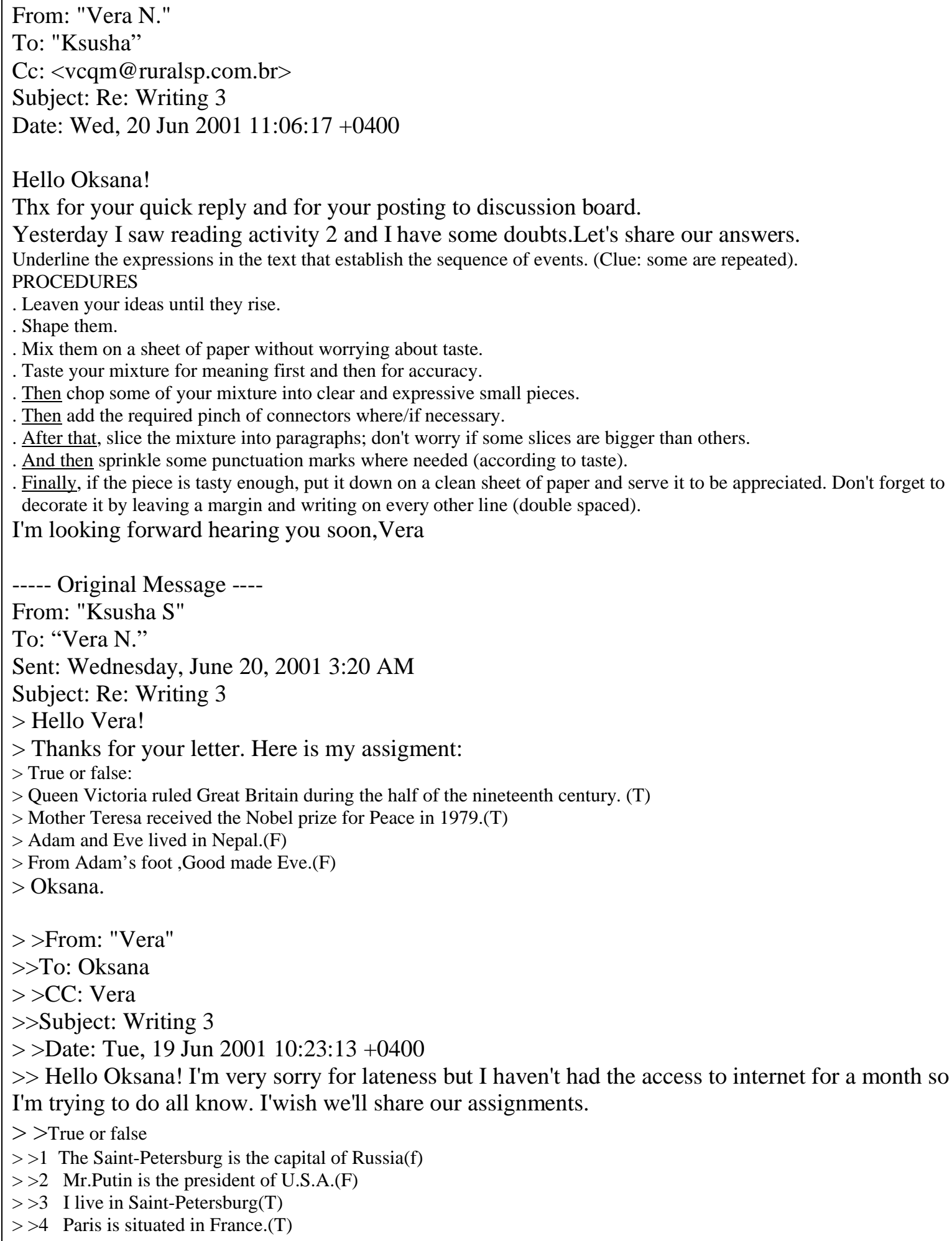


Observa-se neste exemplo, o interesse em compartilhar dúvidas (I have some doubts) e as respostas dadas à atividade (Let's share our answers).

\section{$\underline{\text { Exemplo } 5}$}

From: "Ksusha"

To: "Vera N."

Cc: vcqm@ruralsp.com.br

Bcc:

Subject: Re: Writing 3

Date: Sun, 01 Jul 2001 00:51:15 -0000

Hello Vera!

How are you?

Please look at some changes I make.

Please send me yours. And then we will send to Vera new version of this work.

Oksana

Neste último exemplo 5, a mensagem inteira apresenta elementos que parecem indicar que o processo colaborativo foi incorporado nas atitudes destas alunas: Please look at some changes I make. Please send me yours. And then we will send to Vera new version of this work.

Apesar de termos conseguido suscitar algumas atitudes colaborativas, as dificuldades encontradas talvez se justifiquem pelo fato de que, assim como nós professoras estamos passando por um processo de transformação docente que caminha ainda com marcas dos paradigmas tradicionais (de modo autoritário) para um modo colaborativo (democrático) de conduta docente, é preciso considerar que isto também ocorre com os alunos. Tal constatação nos leva a crer ser necessário um período de maturação antes que os resultados de participação colaborativa, esperados por parte dos alunos, possam vir a se intensificar. 
Também a mudança no comportamento do docente não é imediata, mesmo havendo o desejo de que esta ocorra. Uma mudança de atitude implica no professor aceitar os desafios do imprevisto, dos questionamentos inesperados dos alunos - o que põe em xeque os "conhecimentos" supostamente por ele dominados -, e se dispor a desenvolver práticas pedagógicas que lidam com incertezas, contradições, buscas e reflexões constantes. Como todo processo de mudança comportamental, está sujeito a avanços e retrocessos, antes de atingir um novo patamar desejável. É evidente que cada nova conquista serve de base para outras que se vislumbram a medida em que o professor avança em seus conhecimentos e se lança confiante nos caminhos inusitados de uma educação inovadora.

A experiência ao longo do curso, nos mostrou que para que os alunos respondam às provocações didáticas de natureza colaborativa há a necessidade de se montar atividades cuja resolução implique em consultar o outro, ou em atuar junto com os outros para sua realização. Caso contrário, a participação colaborativa é explicitada aos alunos e deles cobrada, em um modelo ainda tradicional de ensino intelectualizado, que atribui ao aluno exclusivamente a responsabilidade da vivência do processo comunicativo/participativo, e exime o professor de assumir em seus procedimentos relacionais e em intervenções didáticas condutas profissionais que resultem nessa vivência.

A questão a ser revista e posta em prática é a que diz respeito à mudança de condutas de aprendizagem centrada na relação linear e vertical professor/aluno para condutas de aprendizagem diversificadas - em que o aluno é levado a descobrir que se aprende a partir de muitas fontes, como através de colegas, leituras de textos na Web, em músicas, cinema, etc, e não somente a partir de conhecimento supostamente transmitido pelo professor. Na verdade, cabe ao docente organizar situações propiciadoras do encontro do aprendiz com as diferentes fontes de conhecimento e facilitadora de ensino da relação 
dos alunos com elas. E que lhes possibilitem perceber no trabalho com seus pares o potencial educador do trabalho coletivo.

Essa modalidade de aprendizagem implica em o aprendiz assumir ativamente o seu papel, uma vez que ao consultar ou ao se defrontar com documentos e fontes diversas, necessita de um critério de escolha; ao trocar informação com pares precisa desenvolver sua argumentação e cotejar pontos de vista; ao entrevistar experts, ou ao consultar bibliografia especializada precisa se manter no assunto focado.

\section{4.- A prendizagens discente e docente resultantes}

\subsection{1.- A prendizagens docentes}

Não se pode relegar a segundo plano, o papel exercido pelo aluno em sua relação com o professor em um ensino norteado pela Pedagogia da Colaboração/Comunicação. Daí a importância de se considerar os pontos de vista do outro "o aluno" como fundamentais tanto para a melhoria da qualidade do ensino quanto para o próprio repensar do professor a respeito de suas práticas docentes.

Levando-se em conta esse princípio, a voz do aluno foi ouvida no desenrolar do curso também no que diz respeito à avaliação do material e das próprias professoras. Através de respostas por eles dadas às questões 4. How would you evaluate the content uploaded e 5. How would you evaluate your tutors? postadas no fórum, no mês de março, sob a temática First Feedback, obtivemos as primeiras opiniões dos alunos, expostas nos excertos a seguir. 


\section{Exemplo 1:}

Current Forum: First Feedback

Date: Wed Mar 72001 2:34 pm

Author: Soco

Subject: First Feedback

Remove

4. How would you evaluate the content uploaded?

Very good, all the material is very useful and we can to learn a lot.

5. How would you evaluate the tutors?

I think that they are very good tutors, because they give us advices and they give us confidence to ask questions, and they encourage us to continue study.

Reply

\section{Exemplo 2:}

Current Forum: First Feedback

Date: Sun Mar 112001 3:50 pm

Author: Slaveia

Subject: Feedback

4. How would you evaluate the content uploaded?

It's OK.

5. How would you evaluate the tutors?

Very good.

\section{Exemplo 3:}

Current Forum: First Feedback

Date: Mon Mar 122001 8:17 am

Author: William

Subject: First Feedback

4. How would you evaluate the content uploaded?

For me this content is very important for my process of learning grammar/writing.

5. How would you evaluate the tutors?

I'm very thankful to you for your effort towards this course. Really, without your help, for me it would be very difficult to get my goal of learning grammar/writing in English. 
Exemplo 4:

Current Forum: First Feedback

Read 10 times

Date: Mon Mar 122001 2:39 pm

Author: Nagy

Subject: First Feedback

Remove

4. How would you evaluate the content uploaded?

In my opinion it's very useful and well built.

5. How would you evaluate the tutors?

I love them!

\section{Exemplo 5:}

Current Forum: First Feedback

Date: Mon Mar 142001 2:39 pm

Author: Lim

Subject: My Feedback

Remove

4. How would you evaluate the content uploaded?

The content so is quite excellent.

5. How would you evaluate the tutors?

Both tutors Ms Norma and Vera are excellents.

Reply

\section{Exemplo 6:}

Current Forum: First Feedback

Date: Mon Mar 142001 2:39 pm

Author: Vera N.

Subject: Feedback

4. How would you evaluate the content uploaded?

I think it's the first step. I've found many ways to study language. I've practice writing english a lot. So I can suggest that all seems to be perfect.

5. How would you evaluate the tutors?

Great! Really!

Good advices and good communication. The possibility to answer for all necessary questions. An interest in each student. It's only qualities of our tutors:))) 


\section{Exemplo 7:}

Current Forum: First Feedback

Date: Fri Mar 162001 3:18 pm

Author: Oksana

Subject: First Feedback

4. How would you evaluate the content uploaded?

I will say: good.

5. How would you evaluate the tutors?

Normal, for my level.

\section{Exemplo 8:}

Current Forum: First Feedback

Date: Sun Mar 182001 7:48 pm

Author: Vanessa.

Subject: My impressions

4. How would you evaluate the content uploaded?

Very good and usufull

5. How would you evaluate the tutors?

Very very nice persons!

Pelas respostas dos 8 alunos às questões formuladas, é possível afirmar que preenchemos as expectativas deles tanto em relação ao material didático disponibilizado on-line quanto às nossas condutas didáticas, naquele período (janeiro/março).

No final de julho por ocasião do término do primeiro momento do curso, novo questionário foi enviado aos alunos para uma avaliação do curso e sugestões para melhoria do mesmo. Novamente, considerou-se preponderante o parecer do aluno para o aprendizado do professor e de sua vivência nesse novo contexto educacional. As respostas obtidas com referência a essas questões são apresentadas a seguir. 
From: "Vera N."

To: <vcqm@ruralsp.com.br>

Subject: Re:Important News

Date: Sun, 5 Aug 2001 17:08:50 -0700

Dear Vera!

I've just received your letter and I'm trying to reply asap.I hope this helps. Here are my answers for your questions:

3. What have you learned in the course? Have the writing and reading tasks been helpful? In what ways?

It's difficult to me to appreciate all my language skills now. I remember entering to this course in January. I remember my shyness and lack of experience in working and learning through Internet. It was very difficult to me to say-you must study English for your own sake.Nobody will help you to do it, but yourself. So,with time passing, I became a little bit more appropriate with my computer, with English and, to say the truth, with Internet.

In Russia,where I actually live,this kind of learning experience is quite new, so my friends and school mates have been wondering that this wouldn't work. But it works. I see now, that I can express my own ideas in English, I can communicate with other people in this language and, especially, I can study and learn almost all subjects on this language.It's quite important,you see. I remember very well a reading task about on-line student. It helped me in the way of structuring my personal work. I realised that if I enroll in this course I must work hard...It was wonderful experience... Also,there was a story to read. It was the first time that I'd ever read whole story in English!Tremendous:-)This one lead to my going to English language resource centre-British Council library. I borrow some civilisation books there, and I can read them:))

Although,it's rather difficult to me to mention all useful subjects of this course,you can trust me,it's really great experience.I hope this work and studying process will be increasing in fourth months.

4. Have you become a better online learner? Have you learned things that you could apply to your personal/professional life? What?

As I've already said, I'm trying to become a better online learner. It's hard,to work on your own, but it works. I think the one important thing I've learnt is to listen to people with whom I'm studying together, to borrow their experiences and to adopt them to your own life. (I don't mention language skills, because I think them for granted)

Also, a big phychological boundary has been broken down. I realised that I can do almost everything and simply rely on others. It's the case when you have your ow motivation and try to adopt other's opinions for this sake. But this opinions develop your own mind, too. So you receive a big power to continue your own work. And your mate receive it,too.These shared experiences are the great stuff, really!

5. What would you suggest to improve the course?

Yesterday, I had an idea about our course. It seems to be difficult when only few persons are participating, but nevertheless..

I suggest to create a special thread with notepad, where everyone could bring all the sites and assignments, which he has done this day. This will help in order that we can share our skills and bring them on equal level.Also this will develop an idea of all-mates collaboration,to say the truth.

Also,I have an idea to our tutors:

Dear Vera and Norma!

May be it will be useful to give us some extra material to work every week? I mean to divide all external links resources in days and to try to do it with all mates.May be discussing them. Furthermore,what do you think about Net-meeting.I know that the name of our course is BMG, but I think that the voice chats will help so that we'll know each other better:-)

6. Has the collaborative work been effective to you? Why? Why not?

In certain ways-yes.I like to work with Oksana, despite the fact that we wotk together very few extent of time. But I also want to discuss our results with other mates.And I suppose, that Oksana will like it,too!

But,also,it's difficult in many points to work together (lack of enthusiasm,lack of studying time,so on and so fourth)

Nevertheless, I've already said-it's perfect opportunity to study to listen to people...

I'm really sorry about possible misprints, but I hope this letter will be understandble:-)

Please,contact me if some help with new comers will be needed.

Cheers,

Vera N. 
From: "Oksana"

To: vcqm@ruralsp.com.br

Subject: Re: Important News

Date: Mon, 06 Aug 2001 22:20:17 +0000

Hello Vera!

3. What have you learned in the course? Have the writing and reading tasks been helpful? In what ways? - A lot, I have improved my skils in English.

4. Have you become a better online learner? Have you learned things that you could apply to your personal/professional life? What?

Yes, I learned English grammar.

5. What would you suggest to improve the course? I don't know. I like my course, it is very interestingly.

6. Has the collaborative work been effective to you? Why? Why not?- Yes, I like collaborative work.

Date: Mon, 27 Aug 2001 15:10:02 +0100 (BST)

From: "Soco"

To: vcqm@ruralsp.com.br

Subject: Re: Important Message

Hello Vera,

3. What have you learned in the course? Have the writing and reading tasks been helpful? In what ways?

Yes, the writing and reading tasks helped me to learn more English.

4. Have you become a better online learner? Have you learned things that you could apply to your personal/professional life? What?

Yes, I learned many things and had the opportunity to share experience with my mates.

5. What would you suggest to improve the course?

Maybe will be useful to have chats once a month.

6. Has the collaborative work been useful to you? Why? Why not?

Yes, I learned with my friends and I improved my English.

Regards,

Soco.

Além das avaliações e sugestões apresentadas, constata-se pela leitura das respostas das alunas, que elas próprias identificaram e se posicionaram a respeito do seu 
desenvolvimento lingüístico e indicaram ter ganho desenvoltura em relacionamentos colaborativos de ensino-aprendizagem.

A experiência adquirida no primeiro momento do curso aponta para alguns pontos relevantes da aprendizagem do professor:

$>$ a viabilidade de aprendizagem colaborativa sobre ensino on-line entre professores;

$>$ a necessidade de aprender a construir atividades de ensino cuja realização implique no trabalho com o outro de forma colaborativa;

a necessidade de traçar o perfil da "cultura didática anterior" do aluno e, a partir disso, introduzir e orientar para a "cultura da aprendizagem colaborativa";

o papel da pesquisa do professor sobre o ensino-aprendizagem colaborativo on-line durante a sua realização, constituindo-se assim em procedimento de formação profissional continuada.

Essa experiência mostra que, mesmo no ambiente virtual, através de uma metodologia de ensino-aprendizagem colaborativo/comunicacional em que as trocas de informações, as experiências e os conhecimentos são valorizados, é possível ao professor desenvolver nos alunos atitudes individuais e coletivas necessárias para otimizar a aprendizagem. Todavia, ressalte-se que o processo de aprendizagem colaborativa on-line ainda se mostra como desafio tanto para o professor como para o aluno.

Quanto à aprendizagem afetivo/relacional proporcionada pela pedagogia colaborativa/comunicacional, tem-se que ela é duplamente considerada como importante fator de aprendizagem: em si mesma, tendo em vista o projeto de construção da sociedade 
democrática que almejamos, em que o exercício da alteridade é fundamental; e nas relações que proporciona com o conhecimento, estendido pelos mais diferentes tipos de fontes de saber.

A separação física e geográfica dos alunos não se constituiu em empecilho para o desenvolvimento de relações sócio-pedagógicas favorecedoras de processos cognitivos. A distância geográfica foi "neutralizada" ao longo do curso pela "não distância psicológica/emocional” (MOORE, 1993) que se estabeleceu a partir do clima de confiança criado entre as professoras e entre elas e os alunos, o que serviu de "semeadura" para que a empatia e sociabilidade florescessem.

Uma outra constatação, que não pode deixar de ser mencionada, refere-se ao nome do curso.

A meta principal do domínio de um idioma - seja em sua modalidade escrita ou oral -, é a comunicação entre os seres. Assim sendo, a gramática é um acessório importante nesse processo que tem na viabilização da interação humana seu objetivo maior. É preciso, então, não perder de vista que o seu papel é instrumental e não o foco principal. A partir dessa consideração, entendo que a mudança do nome do curso de $B G W$ (Beginner Grammar Writing) para BWG (Beginner Writing Grammar) mostra-se adequada.

\subsection{2.- Resultados cognitivos de estruturas básicas da língua inglesa}

$\mathrm{Na}$ análise das atividades realizadas, ao longo do curso, constatou-se que a aprendizagem cognitiva de conteúdo específico de inglês se efetivou. Isto pode ser 
verificado, por exemplo, através das seguintes mensagens coletadas das alunas Vera N. e

Soco em dois momentos específicos: início e final do curso.

Current Forum: What does success mean to you?

Read 15 times

Date: Sun Feb 112001 8:36 am

Author: Vera N.

Subject: Be successful!

Remove

It's difficult to give the clear and dab explication to the notion of success. Everybody has his own opinion about the theme.

To my mind "be successful" is to be independent with your opinions, to know what you want from your life and realise what's going to pass the next day.

You may interact with people, reach perfect results in your work but the most important quality to be successful is to be understand by yourselves. It's my opinion and l'd like to hear yours.

Current Forum: Virtual Writing Room

Date: Tue Jul 242001 7:34 am

Author: Vera N.

Subject: My learning style

Hi there!

I have had very slim possibility to be here during these two weeks, but I must say at first that I've done all the assignments and the last one-about learning style, helped me a lot in my further studies.

My way is visual-written. So, I have to study mostly by my own.

The receipts of learning mentioned in the text above helped me in improving of my language skill. I'm attend intensive English course in Saint Petersburg right now. It seems to be great. I see how my vocabulary and grammar skills have been improved. Nevertheless, I know that the only way I can study is to study for own sake. If I don't do so, nobody will ask me to read texts, write the new words and ckeck them in monolingual dictionary. So the advices were good, especially of making flash cards. It helps me enormously in learning new vocabulary items. Also, these weeks, I realised how useful our community is for me. It's not only great fun, but also a possibility to learn how to study and perform. Obviously, this way helped me and learnt me.

And it's tremenodous! Thanks a lot :-)

Current Forum: English is easy to learn

Date: Tue Feb 132001 1:12 pm

Author: Soco

Subject: English is not that easy to learn

"English is easy to learn and that's why I chose an online course"

I don't agree with the statment above. English is not that easy to learn alone. The language has a great number of expressions and verbs one has to learn, and the pronunciation is very important too.

At the moment is better for me to take an online course. And I think that it will help me a lot. 


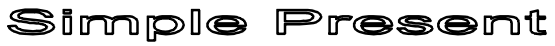

I- Complete the sentences in a meaningful way.

FRIENDS are comprehensives when times are rough. (adjective)

FRIENDS understand and know what we feel. (verb)

FRIENDS are always ready to help us. (verb)

FRIENDS will not let us down.

FRIENDS are to be remembered and kept in our heart. (noun)

II- Write a short paragraph about your country.

\section{MEX I C O}

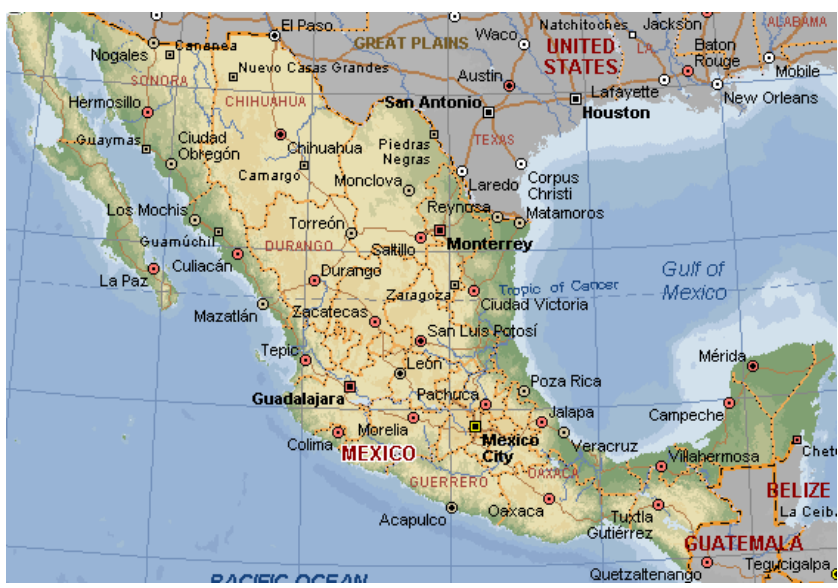

Mexico is located into the American Continent. It has borders with USA at the north, and with Guatemala and Belize at the south.

The climate depends on the Mexico's zone, there are dry, very dry, warm humid and warm subhumid zones. The dry climate predominates at the north of Mexico.

The capital is Mexico City, which is a big city. In Mexico the official language is Spanish, but there are many dialects.

Mexico celebrates many holidays, however I think that the most important are The Day of the Death (the $2^{\text {nd }}$ of November) and Guadalupe Virgin's day (the $2^{\text {nd }}$ of December).

Mexico has a lot of places to visit. The most visited by the international tourism are the beaches and the archaeological ruins.

Tip: Mexico is a big country, it is a good recomendation to restrict itineraries to the main tourist routes.

O desenvolvimento da habilidade de escrita das alunas se evidencia (no final do curso) através da construção de um texto mais estruturado e longo, e de conteúdo melhor elaborado, em que os erros gramaticais e lexicais não comprometem a compreensão das mensagens.

Outro aspecto que aponta para o desenvolvimento da habilidade de escrita adquirida pelas alunas referenciadas e de sua desenvoltura com o código lingüístico está no 
fato delas poderem se expressar e serem compreendidas por múltiplos interlocutores e não apenas pelo professor de idiomas, acostumado que está em "deduzir" o que o aluno quer dizer. Tomando-se novamente como exemplo o texto de Vera N., redigido em 24 de julho de 2001, observa-se que a aluna se expressa de forma clara e demonstra um domínio básico da língua escrita, podendo a mensagem por ela produzida ser lida e compreendida por qualquer leitor que conheça o idioma inglês.

Como a colaboração entre os sujeitos do curso na vivência do processo de ensino aprendizagem supõe um preparo pessoal e organizacional que antecede o trabalho coletivo, para o seu bom andamento, houve-se por bem, na avaliação dos resultados cognitivos, verificar que porcentagem do total das atividades propostas foi bem sucedida. Constatamos que $89,5 \%$ corresponderam satisfatoriamente aos objetivos com que foram propostas.

Todavia, seis delas $(10,5 \%)$ não obtiveram nenhum tipo de resposta dos alunos. O que nos leva a considerar oportuno uma avaliação mensal feita pelos estudantes, das atividades propostas durante o mês, com a finalidade de saber qual atividade o aluno mais gostou e qual atividade ele menos gostou e o motivo de sua resposta. Tal procedimento auxiliará o professor a não reincidir em atividades que não tiveram repercussão entre os alunos.

Quanto às atividades bem sucedidas (89,5\%), a temática Troubleshooting, disponibilizada no fórum, era o espaço de observação do professor sobre os resultados obtidos. O e-mail de respostas de exercícios enviados a mim pelos alunos constituiu outro espaço desse tipo de observação.

As manifestações colhidas sobre o trabalho realizado pelos alunos foram de quatro tipos: pedido de esclarecimento; solicitação de material suplementar; indagações sobre outras alternativas corretas viáveis, e apreciação e comentários/observações do professor. 
Saliente-se que mesmo nos casos em que para as tarefas de correção era fornecida a chave de respostas, os três primeiros tipos de manifestações ocorreram.

\section{Pedido de esclarecimento:}

Current Forum: Grammar Troubleshooting

Read 10 times

Date: Sun Mar 182001 8:48 pm

Author: Vanessa

Subject: Assignment problem - rearrange the phrases!

They were wrong. What is my problem?

How can I fix it?

1. several hailstones broke the Windows.

2. Marty put in the seat next to Brenda.

A aluna Vanessa solicita maiores esclarecimentos a respeito de uma atividade de re-ordenamento de sentenças constituintes de um parágrafo (How can I fix it? 1. several hailstones broke the Windows. 2. Marty put in the seat next to Brenda) sobre a qual teve dificuldades, após ter comparado suas respostas com às da chave de respostas fornecida pelas professoras (They were wrong. What is my problem?)

Indagação sobre outras alternativas corretas viáveis:

Current Forum: Grammar Troubleshooting

Read 12 times

Date: Sun Mar 42001 12:28 pm

Author: William

Subject: Linking words

$\mathrm{Hi}$,

In the sentence: 3 . She had seen very few men while leaving the convent.

Can I use before instead of while.

Thanks for your help. William 
Neste exemplo, o aluno William questiona a possibilidade de uso da conjunção (before) ao invés de (while) na oração, o que mostra um avanço em sua aprendizagem da língua inglesa e interesse em seu aprimoramento no idioma, uma vez que não se satisfaz unicamente com a alternativa que lhe foi apresentada na chave de respostas. Busca saber a diferença entre essas conjunções e o uso delas em orações.

Pedido de material suplementar:

Current Forum: Grammar Troubleshooting

Date: Tue Mar 62001 4:16 am

Author: Jiri

Subject: Sentence types

I have to admit, that with this quiz I was mistaken at all. Many years ago I was learning about sentence types at school and till now l'd forgotten a lot of them. On that time, no many teachers were able to speak in English very well and school books were written mainly in the native language. That's the reason I know a lot of sentence types designations, except of the base ones e. g. nouns, verb, adjectives, ..., only in the native language. I will you to advice me a good view of sentence types to review.

Cheers

Jiri

Já o aluno Jiri admite ter tido dificuldades em elaborar a atividade proposta e, por esse motivo, solicita aconselhamento para revisão de tipos de orações em inglês (I will you to advice me a good view of sentence types to review) que lhe permitam avançar em seus conhecimentos a respeito da língua inglesa. 


\section{Apreciação e comentários/explicações do professor:}

Dear Soco,

Take I gander at my comments and suggestions.

1. Are you an online student? Why do you say so?

Yes, I think so. Because, I'm trying to improve my english, and I am studing and doing my best effort in this online course.

English should be written with capital E, right? Can you find a spelling mistake in your answer?

2. What two characteristics mentioned in the reading would you consider the most important ones? why?

I think that, the most important characteristics in the reading are: be self-motivated and self disciplinated, and be able to meet the minimum requirement for the program.

Comments: why did you use a comma after that? After the colon, I suggest that you use the verb in the infinitive or in the ing form.

I think that we need $\sqrt{ }$ be motivated to do something, in this case to attend an online course, and we need to be disciplinated to follow it.

And to do that, we need to be able to meet at least one time a week and do the assignments.

There's something missing between *need and be*. What can you say instead of one time a week? In your last sentence you used be able to meet and you forgot that the other verb has also to be in the infinitive form so that you have parallelism.

Este exemplo compôs um anexo enviado por e-mail à aluna Soco em 2 de julho de 2001 com observações/sugestões feitas por mim a respeito de uma atividade realizada pela aluna.

Os quatro exemplos apresentados evidenciam iniciativas comunicacionais dos alunos, traduzidas em relações sócio-pedagógicas de busca e aprimoramento no idioma inglês, servindo-se para tanto de uma orientação de ensino personalizado, possibilitada pelo ambiente virtual, ao mesmo tempo em que revelam procedimentos de autonomia discente no processo de ensino-aprendizagem.

De modo geral, na aprendizagem dos alunos salientaram-se os seguintes aspectos: 
a viabilidade de aprendizagem colaborativa on-line entre alunos separados geograficamente e de culturas diferentes;

a importância de dar "voz do aluno" na vivência da metodologia colaborativa/comunicacional;

$>$ o desenvolvimento de maior grau de autonomia no percurso de aprendizagem cognitiva de dupla natureza: afetivo/relacional e intelectual.

2.- F ormação e manutencão de uma comunidade de aprendizagem

\section{1.- M otivacão e interesses comuns}

Há de se considerar primeiramente que o interesse e a motivação dos indivíduos são fatores decisivos na formação e manutenção de um grupo qualquer e característicos de uma comunidade virtual (LYMAN, 2004). No caso específico do estudo aqui proposto, o interesse comum que levou o grupo de alunos a se formar foi o aprendizado da língua inglesa como língua estrangeira. A motivação que levou os alunos a se inscreverem em um curso livre de inglês básico on-line variou, o que é mostrado na tabela 7. 
Tabela 7- Motivo de inscrição no curso on-line

\begin{tabular}{|c|c|}
\hline Motivo & Quantidade (=20) \\
\hline Desenvolvimento lingüístico & 7 \\
\hline Aprender gramática e interagir com os outros & 1 \\
\hline Aprender inglês & 3 \\
\hline Desenvolvimento lingüístico e fazer amizade com pessoas de outros países & 2 \\
\hline Desenvolvimento profissional & 2 \\
\hline Desenvolvimento lingüístico para submissão ao exame Toefl ${ }^{117}$ & 1 \\
\hline Fazer amizade com pessoas de outros países & \\
\hline Desenvolvimento lingüístico e profissional e interagir com pessoas de outros países & 2 \\
\hline Não respondeu & 1 \\
\hline
\end{tabular}

Dentre os vários motivos apresentados, o mais freqüente foi o desejo de desenvolvimento lingüístico (70\%); o desejo de se relacionar com pessoas de outros países e fazer amizades ocupou o $2^{\circ}$ lugar (35\%); e o menos freqüente foi o desenvolvimento profissional $(20 \%)$.

Isto nos leva a inferir que nossa proposta de ensino não limitada apenas ao desenvolvimento cognitivo de estruturas básicas da língua inglesa vai de encontro às expectativas de grande parte dos alunos, o que favorece a perspectiva de o curso vir a se constituir em uma comunidade de aprendizagem, especialmente se encaminhado pela didática comunicacional/colaborativa aqui proposta. $\mathrm{O}$ que encontra respaldo nas considerações sobre o desejo feitas anteriormente.

O interesse das professoras foi motivado pelo desafio do trabalho em ambiente online com alunos de culturas diversas, cuja língua materna não era o inglês. O ponto comum de interesse das professoras e alunos era o ensino-aprendizagem da língua inglesa, como

\footnotetext{
117 Toefl é um teste de avaliação de proficiência em inglês necessário a todos estrangeiros que queiram
} realizar seus estudos em universidades e faculdades americanas. 
língua universal, e conhecimento propício ao desenvolvimento de uma cidadania planetária, conforme visualizada por Morin, para a sociedade tecnológica da atualidade.

\section{2.- Indícios de relapões empáticas}

É importante para nós professores considerarmos aqui que a expansão da possibilidade de realização da sociabilidade humana, aberta pela Internet, pode ser pensada como um fator muito favorável ao ensino on-line, uma vez que satisfaz a característica essencial do homem como animal social. É através da sociabilidade inata do ser humano que encontramos, segundo Adler (1967), a origem do sentimento empático.

Um dos aspectos apontados por vários autores estudados (dentre eles, LEMOS, 2002; LÉVY, 1998c; PALLOFF \& PRATT, 1999; RHEINGOLD, 1993) como característico de comunidade virtual é o que diz respeito às relações (pessoais, sociais e afetivas) que se estabelecem entre os indivíduos. Interpreto essas relações como empatia quando reveladoras de alteridade e as considero essenciais para que um curso venha a se configurar como comunidade virtual, já que são propiciadoras de estabelecimento de vínculos entre os membros de um grupo; o que provê a coesão e participação.

Indícios de relações empáticas foram verificados ao longo do curso: a) entre as professoras; b) entre professoras e alunos, c) entre alunos. Os excertos a seguir são ilustrativos dessas ocorrências. 


\section{$\underline{\text { Entre professoras }}$}

From: "Norma"

To: "Vera"

Subject: Im back!!!

Date: Mon, 28 May 2001 09:06:45 -0300

Dear Vera,

Im so so sorry for my absence but I was tied up all this time!!! Now Im a bit more relaxed. So, how are things doing? Can you please tune me up?

Waiting for your news!!

A big kiss

Norma

Reply-- From: Vera

To: Norma

Date: re: I'm back

At 09:06 28/05/01 -0300, you wrote:

<snip> Can you please tune me up?

Dear Norma,

I'm very happy that you're back. There's a lot to be done. We still need to discuss several things in order to make our students cooperate among themselves. I'll contact you later to let you know what I have in mind and to discuss procedures. I have to finish a paper for the university, so if you don't hear from me for a couple of days that is the reason of my silence.

[ ]s, Vera 
From: "Norma"

To: "Vera"

Subject: Im sorry again!!

Date: Tue, 5 Jun 2001 08:50:53 -0300

Vera I have to say sorry again. I was under a simple operation so I was absent from my pc again!!

Nothing serious just some moles to be taken out.

Ive found this site. See if you like it. If you do, we can suggest it to the students.

Hope your studies are going on the right track :-)

Hugs

Norma

The Blue Book of Grammar and Punctuation.htm

Reply -- To: Norma

From: Vera

Subject: Re: I'm sorry again!!

Date: 05/06/2001 15:14

Dear Norma,

I'm happy to hear from you. I hope you have recovered from the operation.

I checked the link and think it's a good idea to add it to the list of external links. There's a file called For further studies where I guess the link really applies.

What do you think? Let's keep in touch.

Please prepare the answer key to the plural exercise you prepared for the students. We can upload the answer at the end of this week. Is it OK with you?

[ ]s, Vera

Nos dois exemplos, a empatia é decorrente da conduta de ambas as professoras revelar a capacidade de colocar-se na posição do outro, de maneira compreensiva, o que se pode constatar pela ausência de cobranças e reprimendas. Orações do tipo: I have to say sorry again (usada pela Norma), e I'm happy that you are back; I'm happy to hear from you. I hope you have recovered from the operation (por mim) são elucidativas desse tipo de atitude empática.

A relação empática que se estabeleceu entre a professora Norma e eu foi se consolidando ao longo do curso na medida em que nossa atuação de partilha, de colaboração e de solidariedade se sedimentou. Orientadas pelo princípio de alteridade, 
buscamos atuar, somando nossas experiências profissionais; dispostas a lidar com as emoções que pudessem nos sobressaltar durante o percurso, e a encarar o papel do outro docente como o de um colaborador (conforme advoga LÉVY, 1998a).

\section{Entre professora e aluno}

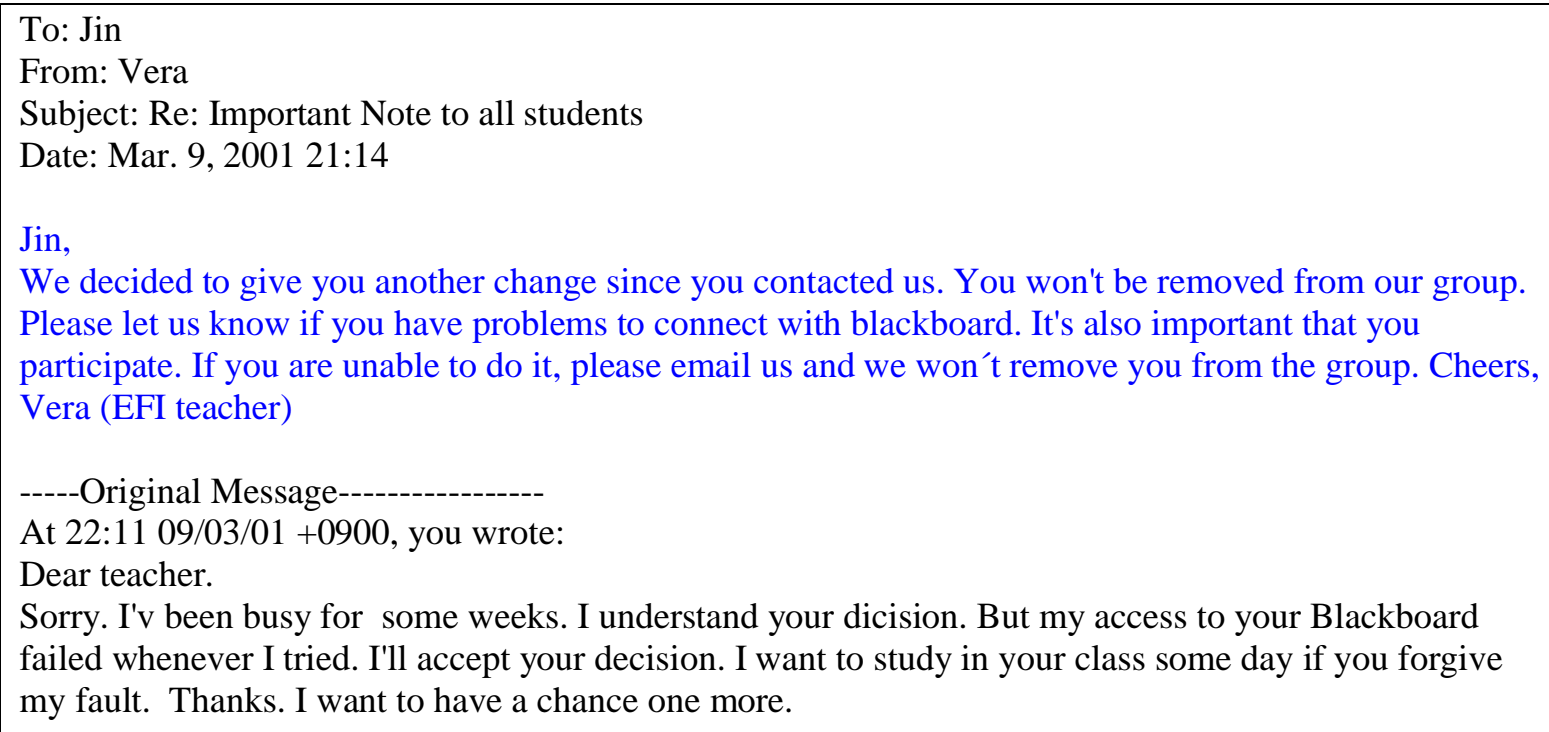

To: Erika

From: Vera

Subject: re: Please reply

Date: Apr 4, 2001 13:27

Sure, Erika. If the problem is only three weeks, that's OK with me. Please send me email when you are ready and always let us know if you are interested in the course, but having any type of problems (ex. school exams).

See you then. Vera (EFI teacher)

-----Original Message----------------

At 17:43 02/04/01 -0300, you wrote:

Dear teacher:

For three weeks i can't handle it, becouse i have university exams. can to continue this course? Thanks, Erika 
To: Ursula

From: Vera

Subject: Re: Please contact me

Date: Jun. 15, 2001 10:47

Dear Ursula,

Don't worry. You will remain in the group. Next week I'll be sending you new procedures. Keep doing the assignments.

Cheers, Vera (EFI teacher)

-------Original Message-

At 07:54 15/06/01 -0700, you wrote:

$\mathrm{Hi}$,

I want to be in group but when I send my assinment answers to William He don't reply. Now I don't know what to do. This BGW is very important for me I do lot of exises on my own and I think it will improve my english.

Cheers,Ursula

As orações - We decided to give you another change since you contacted us / Sure, Erika. If the problems is only three weeks, that's OK with me / Don't worry -, cada qual extraída de um dos exemplos, elucidam a relação empática que se estabeleceu entre eu professora e o aluno. Tais relações são indicativas do compromisso do aluno com a proposta do curso, que solicitava aviso prévio sobre ausência necessária; e de criação de clima propício de aceitação/ acolhimento pela professora da justificativa do problema apresentado. O caráter de tais relações -ocorridas respectivamente em março, abril e junho-, já pode ser entendido como fruto de colheita da sementeira cultivada. 
$\underline{\text { Entre alunos }}$

Current Forum: My first experience at Blackboard

Read 11 times

Date: Sun Mar 42001 11:53 pm

Author: Ingrid

Subject: Re: My first experience

Remove

You are right, Rosy, it is good to see that other students have similar problems. I'm giving my best effort to inprove mi grammar.

Reply

Current Forum: Chat

Read 16 times

Date: Thu Mar $1520011: 55$ pm

Author: Soco

Subject: Re: About Chat

Remove

Hi Vera!

Thanks for your comments about the chat. I think that we should collaborate in this sessions too .... <snip>

Regards,

Soco.

Reply

No primeiro exemplo, indicação de empatia é observada quando a aluna se posiciona em concordância com a colega (You're right, Rosy) e se identifica com o problema daquela (it is good to see that other students have similar problems). Já no segundo exemplo, tem-se a expressão de apoio / posicionamento a favor do procedimento da colega em compartilhar comentários com o grupo (Thanks for your comments about the chat).

É interessante observar também o seguinte exemplo: 
Current Forum: How you relate with others

Date: Mon Mar 52001 1:37 pm

Author: Soco

Subject: How you relate with others

Remove

I think that I am a friendly person. I like be nice with other people. Normally I aware of the people's feelings, because is important to understand them.

Embora este não seja exemplo de relação empática entre alunos, fica evidenciada a compreensão do conceito de empatia por parte da aluna (... I aware of the people's feelings, because is important to understand them).

Outros exemplos similares a este último foram encontrados no mesmo fórum sob o tema How you relate with others. Acredita-se ser importante mencionar tal constatação. Entretanto, não nos ateremos a esses exemplos, uma vez que o interesse é por indícios de relações empáticas entre os alunos.

Outra constatação de que me dei conta, a uma certa altura da realização do curso, que por se orientar por uma metodologia colaborativa/comunicacional permite que alunos e professores ensinem e aprendam uns com os outros, foi minha preocupação maior com o desenvolvimento das relações empático-afetivas com os alunos do que com o seu desenvolvimento cognitivo. Essa distinção maior atribuída à construção de relações empático-afetivas pode ser indicadora de uma apreensão ainda intuitiva, durante a experiência, da importância de propiciar relações sócio-pedagógicas dessa natureza para a construção do clima favorável e adequado ao bom desenvolvimento das aprendizagens intelectuais. $\mathrm{O}$ que se esclarece nesse momento de análise no qual nos conscientizamos de que as relações sócio-pedagógicas de natureza empático-afetivas não aniquilam o desejo de 
aprender; elas são a "mola mestra" do desencadeamento de processos cognitivos de qualquer natureza.

\section{3.- Comprometimento com o grupo}

Interesse, motivação, empatia possibilitam estabelecer mais facilmente o comprometimento dos indivíduos com o grupo. O comprometimento com o grupo (apontado como uma das características de comunidade virtual por LAISTER \& KOBER, 2002 e por WILSON, 2001) foi analisado sob duas perspectivas: a do professor e a do aluno.

No primeiro caso, considerou-se compromisso o assumido pelas professoras de acolher dúvidas dos alunos, estar disponível para dar atendimento individualizado a eles sempre que necessário, e dar constante incentivo à participação do aluno, exaltando suas contribuições. Esse tipo de postura das professoras é importante para suscitar no aluno a manutenção do desejo, a confiança e a vontade de aprender - itens incluídos nos estudos de Wilson (2001) e de Lyman (2004) sobre comunidades virtuais de aprendizagem.

Vejamos os exemplos a seguir: 
Current Forum: Technical Problems

Date: Fri Mar 92001 3:59 pm

Author: Oksana

Subject: Quizzes

Remove

Hello! I have a problem with http://cctc2.commnet.edu/cgi-shl/quiz.pl/modal quiz.htm

and

http://cctc2.commnet.edu/cgi-shl/par numberless quiz.pl/caps quiz.htm

When I had been taking a tour I had clicked on Quizzes, I got messages: can't found page.

Could you help me please?

Oksana

Current Forum: Technical Problems

Read 10 times

Date: Fri Mar 92001 6:08 pm

Author: Vera

Subject: Re: Quizzes

Remove

Click on external links and you will find the link to the quizzes you want to take. If you have problems, email me.

Vera

Reply

Current Forum: Grammar Troubleshooting

Read 14 times

Date: Thu Feb 222001 12:14 pm

Author: Soco

Subject: Linking words

Ramove

$\mathrm{Hi}$,

In the sentences:

6. She worked as a maid when she first came to London.

Is it possible to use until instead of when?

7. She met her husband while she was working as an air-raid warden.

Is it possible to use when instead of while?

Soco 
Current Forum: Grammar Troubleshooting

Date: Fri Feb 232001 6:55 am

Author: Norma

Subject: Re: Linking words

6. She worked as a maid when she first came to London.

Is it possible to use until instead of when?

Pay attention that if you use UNTIL you will change the meaning.

Until is used to talk about a continuing situation or state that will stop at certain moment in the

future. And WHEN is used to express a simultaneous event.

7. She met her husband while she was working as an air-raid warden.

Is it possible to use when instead of while?

Yes. Read above.

Good job!! Congrats!!!

Norma

Esses exemplos ilustram tipos de dúvidas pessoais apresentadas pelos alunos (uma de ordem técnica e outra de natureza lingüística) e as respostas dadas pelas professoras para sanar os problemas. É importante ressaltar que nós professoras tentávamos, dentro do possível, responder às dúvidas dos alunos colocadas no fórum o quanto antes possível e que as respostas eram dadas por aquela de nós que tivesse lido a mensagem primeiro.

$\mathrm{O}$ incentivo à participação do aluno, visto como outra iniciativa que revela o compromisso do professor com o grupo, pode ser observado nas comunicações seguintes: 
Date: Wed, 3 Jan 2001 12:26:27 -0500

To:

From: vcqm@ ruralsp.com.br

CC:

Subject: Take a look!

Dear students,

Vera N. has already edited her homepage. Take a look at it! It's really nice. Comments are welcome :-)

Also, read what Vera and Lim say about learning English.

Cheers,

Current Forum: My first experience at Blackboard

Read 15 times

Date: Tue Mar 62001 6:38 am

Author: Norma

Subject: Re: My first experience at Blackboard

Nice Soco!!! Your approach to learn is great. Keep it up!!! Norma

As contribuições dos alunos são exortadas pelas professoras com o propósito de estimular novas contribuições e a manutenção do desejo. Os exemplos apresentados caracterizam o nosso compromisso com o grupo de alunos.

No primeiro exemplo, parabenizamos a aluna pela criação de sua página pessoal (Vera $N$. has already edited her homepage. It's really nice), incentivamos a visita e comentários a respeito dessa página pelos outros alunos (Take a look at it! Comments are welcome), e os convidamos para a leitura das colocações feitas por 2 colegas no fórum 
sobre aprendizagem de inglês (Also, read what Vera N. and Lim say about learning English).

Embora não tenhamos ensinado os estudantes a criarem suas páginas pessoais, essa tarefa podia ser realizada, uma vez que o próprio programa Blackboard disponibilizava uma ferramenta para tal, o que não exigia do aluno conhecimentos de linguagem de computação.

No segundo exemplo, exaltamos a abordagem feita por Soco sobre aprendizagem (Nice Soco!!! Your approach to learn is great. Keep it up!!!)

Com relação ao aluno, o comprometimento - ligado ao caráter de sociabilidade do indivíduo-, é verificado pelas atitudes em relação ao outro, de compartilhamento/ troca de informações, e pelo interesse na contribuição do colega.

Current Forum: My first experience at Blackboard

Read 25 times

Date: Thu Feb 82001 8:54 am

Author: William

Subject: My first experience at Blackboard

Remove

I appreciate very much Vanessa's proposition. My first experience with the Quiz "Cinderella" was terrible: cero score, eigh minutes (we only have five), one tense mistake, so I realized I need to practice a lot. I will continue exploring this page because I think, in a short time I will have learnt much of English than I know now and this way is very fun.

In addition to Vanessa's proposition I suggest we can see Vera's Fun Pages \& Voicemessaging at the site www.Study.com. Your comments will help me.

William 
Current Forum: My first experience at Blackboard

Date: Sat Mar 32001 2:06 pm

Author: Rosy

Subject: My first experience at Blackboard

Remove

The first time I knew nothing but did homework as the teacher mentioned. I checked the task, but it was empty. Then I began to click every option to see what there are inside. I read others article, to learn something from others.

Reply

Current Forum: Proverb

Read 14 times

Date: Tue Mar 62001 4:40 am

Author: Jiri

Subject: Proverb

Remove

Yes, I agree. If more people or things do the same action withoat collaboration, the result may be mazy. How does it look in reality?

Look at: http://www.harry-the-planet.demon.co.uk/cooks.html

Reply

From: "William Muriel Silva" <william_muriel@ hotmail.com>

To: vcqm@ ruralsp.com.br

Subject: Re: Home Pages

Date: Mon, 26 Feb 2001 21:36:40 -0500

Dear Teacher Vera:

I have just uploaded my pic, and I have submited the information of my homepage, but I can`t see the other students when I visit Blackboard.

Could you tell me the link for visiting our cybermates` pages.

I look forward to hearing from you.

Thanks, William.

As trocas de fontes de informação entre os alunos (apontada por PALLOFF \& PRATT, 1999 como peculiares em comunidades virtuais de aprendizagem) foram constatadas em nossos dados e ocorreram sobre links sugeridos para consulta.

O interesse pelas contribuições do outro foi verificado tanto pelo questionamento feito pelo aluno de como acessar, por exemplo, a homepage do colega para visitá-la, quanto 
através do número de leituras das mensagens postadas no fórum, o que é registrado individualmente nas mesmas de forma automática pelo sistema do Blackboard.

Outro ponto relevante verificado é o que diz respeito à opinião do aluno em relação à contribuição de um colega: I appreciate very much Vanessa's proposition.

Ocorreram, pois, em nosso curso experimental indícios explícitos de comprometimento por parte dos professores e de alunos com o grupo.

Tentou-se ao longo do curso criar uma "cultura" - mesmo que com bases ainda incipientes -, onde a comunicação didática se efetuou de forma horizontalizada (LAISTER \& KOBER, 2002). Essa democratização das relações de ensino é também prevista pela metodologia comunicacional de ensino (PENTEADO, 2002).

\section{4.- T empo de ex posição no grupo}

Rheingold (1993) assinala o tempo como fator importante para que se estabeleçam relações pessoais no ciberespaço.

O tempo de realização do curso $B G W$ estendeu-se por um período mais longo do que o previsto, que era de 2 meses, o que sugere o estabelecimento de vínculos entre os indivíduos componentes do curso on-line.

Dos 20 alunos que iniciaram o curso, 12 permaneceram de janeiro a abril (por 4 meses), o dobro do tempo proposto no projeto inicial. 3 justificaram o desligamento através de mensagem enviada por e-mail -2 deles por não terem acesso ao computador em casa, e 1 por ter sido promovido em seu trabalho a um cargo que requeria maior tempo de serviço e 
dedicação. Os outros 5 alunos não se manifestaram, sendo que 3 deles nunca realmente estiveram envolvidos no curso, apesar dos "lembretes" por mim enviados. Desses 5, apenas um surpreendeu, pois embora fosse bastante participante, não se manifestou quanto ao seu desligamento do curso.

De maio a julho, o número de participantes ativos limitou-se à apenas 6 . Os outros 6 foram, excluídos do grupo. Esses alunos não enviaram qualquer notificação esclarecedora de ausência durante 2 semanas, o que era norma do curso, quando precisassem ficar inativos por duas semanas, para que pudessem permanecer.

A tabela ${ }^{118}$, a seguir, possibilita a visualização da demografia do curso em seu desenrolar, os desligamentos justificados, evasões e exclusões.

Tabela 8 - I Momento do Curso BGW

\begin{tabular}{|l|l|c|l|l|l|l|}
\hline Curso & $\begin{array}{l}\text { Número total de } \\
\text { alunos inscritos }\end{array}$ & $\begin{array}{c}\text { Período de } \\
\text { realização } \\
(\mathbf{2 0 0 1})\end{array}$ & $\begin{array}{l}\text { Alunos } \\
\text { remanescentes }\end{array}$ & $\begin{array}{l}\text { Desligamentos } \\
\text { justificados }\end{array}$ & Evasão & Exclusão \\
\hline BGW & 20 & janeiro-abril & 12 & 3 & 5 & \\
\hline & & $\begin{array}{c}\text { maio-meados de } \\
\text { julho }\end{array}$ & 6 & & & 6 \\
\hline
\end{tabular}

A duração do curso no tempo mostrou-se uma variável significativa para a aprendizagem da conduta colaborativa entre os sujeitos do curso. Verificou-se o início de vivência pelos alunos de atitudes colaborativas 3 meses depois do início do curso (março de

\footnotetext{
${ }^{118}$ Estou usando o termo desligamento com o significado de abandono justificado do curso; evasão como abandono do curso (sem justificativa), e exclusão como ato realizado pelo professor.
} 
2001). Por se tratar de uma proposta nova a ser vivida por professores formados no ensino ainda fortemente tradicional e por alunos também possivelmente procedentes de experiência escolar com essa metodologia de ensino é preciso um tempo para que a semeadura da nova metodologia germine, e, após, um tempo para amadurecer as vivências das experiências com ela. O que no nosso caso compreendeu 3 meses para a germinação e os outros meses para o amadurecimento das experiências colaborativas.

$\mathrm{Na}$ proposta inicial, o tempo que os alunos teriam que despender com o curso foi especificado na ementa. Sugeria-se acesso ao programa, pelo menos, 2 vezes por semana.

Já o tempo necessário de atuação docente na modalidade on-line não foi cogitado, a priori, pois se tratava de um trabalho voluntário meu e da professora Norma. Estávamos mais preocupadas e interessadas com a experiência e resultados advindos do curso que trariam dados relevantes para outros projetos nossos de ensino on-line. Todavia, há de se convir que o tempo despendido para ministrar o curso on-line foi certamente maior do que para um curso presencial. Isto porque além do tempo normal gasto na preparação de material e nas correções foram necessários: tempo para disponibilização de material on-line; tempo para leituras de mensagens/parágrafos postados no fórum, e tempo para redigir respostas e esclarecimentos de dúvidas dos alunos.

Segundo Palloff e Pratt (1999), para ministrar um curso on-line consomem-se 2 a 3 vezes mais tempo do que para um curso presencial. Embora à primeira vista isto possa parecer fator negativo para a realização de cursos on-line, deve-se lembrar que se trata de uma nova modalidade de ensino, e como tal, requer ajustes, adaptações e vivências concernentes à administração do tempo docente que só se delimitará com maior precisão a partir dessa prática. 
É fundamental esclarecer ainda que por estarmos lidando com uma proposta de docência colaborativa/comunicacional, se por um lado exigiu maior disponibilidade de nós professoras para o planejamento e a elaboração conjuntos das atividades do curso; por outro, minimizou o tempo despendido com as correções e comentários a respeito das respostas dos alunos às atividades didáticas, pois, conforme mencionado anteriormente, essa tarefa foi atribuída, sempre que possível, e assumida pelos alunos e repartida entre a professora Norma e eu sempre que necessário.

No início de julho, fui notificada pela professora Norma de sua viagem ao exterior, e de seu desligamento do grupo $B G W$ (pelo menos, durante algum tempo ${ }^{119}$. Independentemente desse fato, resolvi dar prosseguimento ao meu trabalho on-line.

Uma vez que o grupo de alunos havia se reduzido a menos da metade, decidi que novos alunos seriam aceitos para compor um novo grupo, o que definiu, claramente, um segundo momento deste curso.

Antes de dar início à nova etapa, enviei, via e-mail, um breve questionário (Apêndice E) com 6 questões referentes ao curso e ao interesse dos alunos remanescentes em continuá-lo. Dos 6 alunos remanescentes do primeiro momento, 3 (2 alunas da Rússia e 1 do

\footnotetext{
${ }^{119}$ From: "Norma"

To: "Vera"

Subject: thanks for letting me work with you

Date: Mon, 2 Jul 2001 14:54:00 -0300

Dear Vera,

[...] But I will not stop. Once in Italy I will continue as soon as I can connect to a pc. So please don't leave me aside! and don't forget me!! :-)

One thing I would like to ask you is, if you can send me some material to read about teaching on line. Do you have some? or do you have any place in the net where I can visit and read?

I would really appreciate this because I'd like to update myself a bit more in this matter. In case you need sth just let me know. I will be here whole July.

Hugs,

Norma
} 
México) responderam ao questionário por e-mail. Uma aluna (da Itália) enviou uma mensagem, notificando ter que deixar o curso por estar de mudança para outro país.

O conjunto de fatores aqui considerados - motivação e interesse comum, aplicação da metodologia voltada à aprendizagem colaborativa/comunicacional, com o estabelecimento de relações empáticas, o comprometimento dos membros com o grupo e o tempo de exposição no grupo -, elencados como características de uma comunidade virtual de aprendizagem, permitiu perceber o nascimento de uma comunidade de aprendizagem a partir de nosso curso experimental.

A permanência e a migração de alunos do primeiro momento do curso para o segundo reforçam essa percepção. 


\title{
Capítulo IV - Frutos
}

\author{
ou \\ C onsiderações Finais
}

"O homem se compreende somente quando ele testa a inteligibilidade de suas palavras, expondo-as aos outros" (VON HUMBOLD). ${ }^{120}$

"O importante é nunca parar de questionar"

$(\text { ALBERT EINSTEIN) })^{121}$

A pesquisa realizada com a proposta pedagógica experimental aponta para propriedades da didática colaborativa/comunicacional no ensino on-line e, especificamente, no ensino on-line de inglês como língua estrangeira, junto a discentes de diferentes países e culturas, aqui focalizado. Muitas delas já foram esclarecidas ao longo da análise dos dados coletados.

Ao término deste trabalho me deterei naquelas propriedades que entendo como prioritárias nessa passagem para uma nova proposta de ensino mediado por computador, e que, embora tão ou mais importantes do que as já relatadas, ficam diluídas em meio àquelas.

\footnotetext{
${ }^{120}$ No original: "Man understand Himself only once he has tested the intelligibility of his words by trial upon others."

${ }^{121}$ No original: "The important thing is never stop questioning."
} 
Uma dessas propriedades refere-se ao trabalho conjunto entre professores nesses cursos.

A solicitação que recebi da professora argentina sobre organização de cursos online, encaminhou-me a acolhê-la no curso experimental de meu projeto de pesquisa, dividindo com ela encargos didáticos. A partir do motivo que encaminhara sua solicitação de participação, esclareceram-se dois papéis docentes: o de professora colaboradora sugerido por ela e por mim a ela atribuído -, e o de professora pesquisadora, por mim desenvolvido nessa experiência. O conflito explicitado em passagem já descrita sobre a apresentação aos alunos de objetivos das atividades a eles propostas, permitiu-me perceber a importância da partilha dos fundamentos teórico-metodológicos do curso com o parceiro docente em cursos dessa natureza, desde o início dos trabalhos, o que não fora feito até então. Todavia, a forte vinculação mantida ao longo da pesquisa com os fundamentos teóricos que a embasaram, possibilitou também apreender o papel educativo do "erro ou lacuna" no processo de ensino-aprendizagem colaborativo/comunicacional. Diferentemente do que acontece no ensino tradicional, o "erro" passa de estigma à "mola propulsora de aprendizagem" (KRASILCHIK, 2001; PENTEADO, 2002).

Vista sob essa mesma ótica, a "evasão e exclusão" que ocorreram ao longo do curso, não se constituem em fator negativo ou desmotivador do ensino on-line, orientado pela Pedagogia da Colaboração/Comunicação. São esperadas, já que os alunos muitas vezes só se dão conta dessas transformações e de suas implicações ao vivenciar o curso, apesar de terem sido para elas alertados e nelas introduzidos teoricamente no início.

Outra propriedade relevante refere-se a docentes/discentes nesses cursos. A vinculação com os fundamentos teórico-metodológicos de pesquisa também possibilitou 
perceber a relevância de o docente e o discente se aceitarem como parceiros ou coresponsáveis no ensino-aprendizagem no qual estão envolvidos. Tal conduta, entretanto, expõe o professor a situações imprevistas de aprendizagem, a confrontos e a questionamentos por ele não vivenciados anteriormente. Todavia, o risco de exposição a esses tipos de situações passa de "ameaçador" para "desafiador", pois se caracteriza pela busca de novas provocações didáticas, no caso do professor, e de caminhos educacionais, no caso do aluno. Abre, com isso, um amplo leque de possibilidades de busca por parte do estudante de diferentes tipos de fontes de saber, que não mais se restringem à figura do professor.

Uma outra propriedade que merece ser considerada dentro da pedagogia aqui adotada se refere a procedimentos docentes vinculados à organização de cursos de inglês on-line. Um deles diz respeito ao levantamento de conhecimentos prévios sobre o aluno que o professor precisa ter. Para tanto, o questionário inicial deve indagar a respeito das experiências anteriores dos alunos no aprendizado do idioma, para que se possa então construir "pontes" entre a "cultura didática anterior" do estudante e a didática proposta pelo curso, de tal forma a familiarizá-lo com novas condutas de aprendizagem, quando for o caso.

Esse questionário também deve conter uma questão a respeito do conhecimento do aluno sobre o ambiente virtual a ser utilizado. Saltou aos olhos o fato de que, declarar ter um grau de conhecimento de intermediário a avançado a respeito de computação e de Internet, não significa ter familiaridade com qualquer plataforma de gerenciamento de cursos on-line escolhida pelo professor para acomodar seu curso. 
Ressalte-se também a importância de se obter por meio do questionário inicial informações sobre o nível de conhecimento de inglês do candidato. No questionário utilizado a pergunta sobre as expectativas do estudante a respeito do curso pode prover esta informação, já que ele tem que se expressar no idioma estrangeiro.

Um outro procedimento diz respeito à conduta didática a adotar. Observou-se que o ambiente de ensino on-line não implica em uma condução tecnicista de curso. A opção por um processo de ensino humanista e colaborativo encontra no ambiente on-line condições de realização da metodologia colaborativa/comunicacional de ensino que se apresenta como eficiente recurso desta realização.

Outra propriedade se vincula à mudança de atitude docente. Como a didática colaborativa se apóia em uma conduta comunicacional entre professor - aluno / alunoaluno / e todos com o conhecimento organizada de forma horizontal e democrática, a necessidade de mudanças na atitude de "cobranças" junto aos alunos para a realização e participação de atividades didáticas próprias do ensino tradicional se instaura como propriedade significativa. Tais "cobranças" dão lugar aos "convites ou às provocações didáticas" para participação e realização de atividades educacionais que providenciam a superação das dificuldades constatadas.

A coordenação de atendimento individual com o trabalho coletivo no ensino online é prioridade que exige constante atenção às dificuldades dos alunos e equilíbrio nas distribuições das atividades.

A didática colaborativa/comunicacional no ensino de inglês como língua estrangeira adotada no curso livre de inglês on-line expõe a importância do trabalho individual como quesito para o trabalho coletivo. Observou-se que a auto-correção (self- 
correction) e a auto-avaliação (self-evaluation) contribuem para o exercício da autonomia do aprendiz que é, assim, encorajado a "aprender a aprender" e "aprender a fazer". De forma similar, o trabalho coletivo com múltiplos parceiros de aprendizagem em situações de partilha com consulta a diversas fontes do saber contribui para o exercício da alteridade que se vincula diretamente a "aprender a ser" e "aprender a viver/conviver" (DELORS, 1998).

Em situações on-line, o idioma em cursos de língua estrangeira passa a ter papel primordial como instrumento de comunicação entre os participantes. A metodologia colaborativa/comunicacional com que se trabalhou as habilidades de escrita e de leitura desenvolve nesses aprendizes a capacidade de se expressar de forma compreensível (através da escrita) junto a múltiplos interlocutores. Evitam-se, desse modo, as barreiras limitadoras da comunicação através da língua estrangeira, presentes na metodologia tradicional do ensino em que o professor é praticamente o único interlocutor do aluno no processo.

Finalmente a propriedade que diz respeito à formação de uma comunidade virtual de aprendizagem a partir de um curso on-line. Na formação desse tipo de comunidade, quatro variáveis significativas foram observadas durante a realização do projeto experimental aqui estudado: desejo, empatia, sociabilidade colaborativa e tempo de duração.

O desejo constituiu-se no "elemento-chave" que reuniu os aprendizes em torno do interesse comum de aprender - ou se desenvolver na - língua estrangeira (inglês). A empatia (partilha do desejo) e a sociabilidade colaborativa (manutenção do desejo) criadas entre as professoras e os alunos são elementos necessários para se atingir a meta de 
transformação de um curso em uma comunidade de aprendizagem. Ressalte-se o papel da pedagogia colaborativa/comunicacional como responsável pela aprendizagem da conduta participativa e de partilha, propiciadora dos vínculos sócio-afetivo-pedagógicos que levam à formação da comunidade de aprendizagem.

A esses três critérios associe-se o período de tempo de realização do curso. O curso experimental de meu projeto de pesquisa previsto para durar dois meses desdobrou-se em quatro etapas ao longo de dois anos e meio (janeiro de 2001 até julho de 2003). A primeira etapa, sobre a qual incidiu esta pesquisa durou 7 meses. Desta etapa 3 alunas permaneceram até julho de 2003. A elas outros alunos foram se juntando, provenientes dos desdobramentos subseqüentes. A migração de alunos de uma etapa para outra permitiu acompanhar o desabrochar de uma comunidade virtual de aprendizagem a partir do curso realizado.

Espero que os resultados deste trabalho venham a servir de subsídio para novos encaminhamentos de pesquisa sobre cursos livres na modalidade on-line e de comunidades virtuais de aprendizagem. E também para compor os estudos de formação inicial de professor de língua estrangeira que se prepara para exercer a profissão em uma sociedade tecnológica que põe como exigência o uso da tecnologia a serviço do desenvolvimento humano e da construção de uma sociedade mais justa e democrática.

Além disso, esse estudo nos esclarece sobre o pioneirismo dessa modalidade de ensino e nos remete à necessidade da continuidade de pesquisas sobre o ensino on-line que busquem esclarecer questões como: Qual seria o tempo ideal para um curso totalmente online? Deveria o seu tempo ser dividido em módulos? Faz sentido pensar em uma duração ideal para cada módulo? Quais são as exigências de disponibilidade de tempo do professor 
para curso on-line baseado na metodologia colaborativa/comunicacional? Qual o número ideal de alunos - provenientes de diferentes culturas e falantes de diferentes idiomas -, para um bom desempenho de um curso básico de inglês on-line organizado em moldes de uma metodologia colaborativa/comunicacional?

E ainda, além de algumas das questões didáticas aqui levantadas é preciso atentar para uma questão mais ampla, de natureza pedagógica, para a qual nos provoca Lévy: Quais são as repercussões da vivência de relações sócio-pedagógicas em ensino on-line orientado por uma pedagogia colaborativa/comunicacional e em comunidades virtuais de aprendizagem, em relações sociais “territorializadas”?

Fica aqui a minha esperança de que essas questões venham se juntar a outras diversas questões de estudo de outros pesquisadores para contribuir com a construção de um corpo de conhecimentos teórico/práticos enriquecedores do ensino nos novos espaços virtuais de aprendizagem.

E ainda que os critérios: desejo, partilha do desejo e manutenção do desejo, considerados nesta pesquisa como fundamentais para a formação de uma comunidade virtual de aprendizagem sejam retomados e que possam ser avaliados e desdobrados em outras propostas de pesquisa. 


\section{Referência Bibliográfica e W ebgráfica}

ADLER, A. A. A Ciência da Natureza Humana. Trad. Godofredo Rangel \& Anísio Teixeira. 6. ed. São Paulo: Companhia Editora Nacional.

ALMEIDA, M. E. B. Tecnologia e Educação a Distância: Abordagens e Contribuições dos Ambientes Digitais e Interativos de Aprendizagem. In: ASSOCIAÇÃO NACIONAL DE PÓS-GRADUAÇÃO E PESQUISA EM EDUCAÇÃO, 26, 2003, Caxambu. Anais da ANPED... Caxambu: GT 16, ANPED, 2003. Disponível em: <http://www.anped.org.br/26/trabalhos/mariaelizabethalmeida.rtf > Acesso em: 29 mar. 2004.

ANDRÉ, M. E. D. A. de; PASSOS, L. F. Avaliação Escolar: Desafios e Perspectivas. In: CASTRO, A. D. de; CARVALHO, A. M. P. de. (Org.). Ensinar a Ensinar. Didática para a Escola Fundamental e Média. Pioneira Thomson Learning Ltda, 2001. cap. 10, p. 177195.

AZEVÊDO, W. Muito Além do Jardim de Infância - O desafio do preparo de alunos e professores on-line. In: VI CONGRESSO INTERNACIONAL DE EDUCAÇÃO A DISTÂNCIA, 1999, Rio de Janeiro. Texto da Biblioteca Online da ABED... Rio de Janeiro: ABED, 1999. Disponível em:

〈http://www.abed.org.br/paper_visem/wlson_azevedo.htm〉. Acesso em: 16 jun. 2000.

BELLONI, M. L. Mediatização: os desafios das Novas Tecnologias de Informação e Comunicação (NTCI). In: Educação a distância. 2.ed. Campinas. São Paulo: Autores Associados, 2001. cap. 4, p. 53-77. (Coleção educação contemporânea).

BERGE, Z. The Role of the Online Instructor/Facilitator, 1996. Disponível em: <http://www.emoderators.com/moderators/teach-online.html〉. Acesso em: 15 jul. 1999.

BROWN, H. D. Intrinsic Motivation in the Classroom In: Teaching by principles: an interactive approach to language pedagogy. Prentice Hall, Regents, 1994, chapter 3, p.3346.

BROWN, R. E. The Process of Community-building in Distance Learning Classes. JALN Journal of Asynchronous Learning Networks. v. 5, Issue 2, Sept. 2001.

Disponível em: 〈http://www.aln.org/alnweb/journal/Vol5_issue2/Brown/Brown.htm〉. Acesso em: 15 ago. 2002.

CARDOSO, F. H.; IANNI, O. [organização e introdução de] Homem e Sociedade: leituras básicas da sociologia geral. 14. ed. São Paulo: Ed. Nacional, 1984. (Biblioteca universitária; sér. 2, Ciências sociais, v.5.) 
CASTELLS, M. Comunidades virtuais ou sociedade de rede? In: A galáxia da internet: reflexões sobre a internet, os negócios e a sociedade. Trad. Maria Luiza X. de A. Borges, rev. Paulo Vaz. Rio de Janeiro: Jorge Zahar Ed., 2003. cap. IV, p. 98-113

CHICKERING, A. W. \& EHRMANN, S. C. Implementing the Seven Principles: Technology as Lever. American Association for Higher Education, 1996.

Disponível em: 〈http://www.aahe.org/technology/ehrmann.htm>. Acesso em: 11 ago. 2000.

CHIZZOTTI, A. Pesquisa em ciências humanas e sociais. São Paulo: Cortez, 1991. (Biblioteca da educação; ser. 1, Escola, v.16.)

COLLABORATE. In: COLLEGIATE DICTIONARY. Merriam Webster Online. Merriam-Webster, Incorporated. [19--]. Disponível em: 〈http://www.m-w.com/cgi-bin/>. Acesso em: 2 jul. 2002.

COOPERATE. In: COLLEGIATE DICTIONARY. Merriam Webster Online. MerriamWebster, Incorporated. [19--]. Disponível em: 〈http://www.m-w.com/cgi-bin/〉. Acesso em: 2 jul. 2002.

DELORS, J. The Four Pilars of Education. UNESCO Task Force on Education for the Twnty-First Century. 1998. Disponível em: < http://www.unesco.org/delors/>. Acesso em: 20 jul. 2001.

DERTOUZOS, M. L. O que será: como o novo mundo da informação transformará nossas vidas. Trad. Celso Nogueira. São Paulo: Companhia das Letras, 1997.

DILLENBOURG, P. What do you mean by collaborative learning? In:

DILLERBOURG, P. (Ed) Collaborative-learning: Cognitive and Computacional Approaches. Elsevie, 1999. chapter 1. [mensagem pessoal]. Mensagem recebida por <vcqm@uol.com.br>em 18 jun. 2002.

EKHAML, L. Tips for promoting collaboration and interactivity in online distance learning. Compu-Ed, v. 5, 1999. Disponível em: 〈http://computed.coe.wayne.edu/Vol5/Ekhaml.html〉. Acesso em: 10 jun. 2001.

FERREIRA, A.B. de H.; J.E.M.M. Editores, LTDA (1988). Dicionário Aurélio Básico da Língua Portuguesa. Rio de Janeiro: Editora Nova Fronteira S.A. Obra em 19 fascículos semanais encartados na Folha de São Paulo, de outubro de 1994 a fevereiro de 1995.

FEENBERG, A. Distance Learning: Promise or Threat? [a slightly longer version of a paper published in Crosstalk, winter, 1999]. Disponível em: <http://wwwrohan.sdsu.edu/faculty/feenberg/TELE3.HTM>. Acesso em: 10 ago. 2002. 
GARRIDO, E. Sala de Aula: Espaço de Construção do Conhecimento para o Aluno e de Pesquisa e Desenvolvimento Profissional para o Professor. In: Ensinar a Ensinar Didática para a Escola Fundamental e Média. Pioneira Thomson Learning Ltda, 2001. cap. 7, p. 125-139.

GUIMARÃES Jr., M. J. L. A cibercultura e o Surgimento de Novas Formas de Sociabilidade. In: II REUNIÓN DE ANTROPOLOGIA DEL MERCOSUR. GT Nuevos mapas culturales: Cyber espacio y tecnologia de la virtualidad, Piriápolis, Uruguai, 1997. Disponível em 〈http://www.cfh.ufsc.br/ guima/>. Acesso em 10 jul. 2002.

HEIDE, A. \& STILBORNE, L. Guia do Professor para Internet: completo e fácil. Trad. Edson Furmankievz. 2.ed. Porto Alegre: Artes Médicas Sul, 2000.

ILLINOIS ONLINE NETWORK. Chat as a teaching tool. Pointers \& Clickers. Nov. 1999. Disponível em: 〈http://illinois.online.uillinois.edu/pointers/>. Acesso em: 23 abr. 2001.

KENSKI, V. M. Comunidades de Aprendizagem, Em Direção A Uma Nova Sociabilidade na Educação. Excerto do artigo publicado na Revista de Educação e Informática Acesso. SEED/SP - n.15/dez. 2001.

KIM, A. J. Community Building on the Web. Peachpit Press, division of Addison Wesley Longman, 2000.

KOZMA, R. Learning with Media. Review of Educational Research. Summer 1991, v. 61, n. 2, p. 179-211.

KRASILCHIK, M. As Relações Pessoais na Escola e a Avaliação. In: CASTRO, A. D. de; CARVALHO, A. M. P. de (orgs.). Ensinar a Ensinar. Didática para a Escola Fundamental e Média. Rev. Janice Yunes. SP: Pioneira Thomson Learning, 2001. cap. 9, p. 165-175.

LAISTER, J. \& KOBER, S. Social Aspects of Collaborative Learning in Virtual Learning Environments. Networked Learning Conference, 2002. Lancaster University and University of Sheffield. Disponível em: <http://www.shef.ac.uk/nlc2002/proceedings/papers/19.htm>. Acesso em: 5 abr. 2004.

LAROCQUE, D. \& FAUCON, N. Me, Myself and ... You? Collaborative Learning: Why bother. Teaching in the Community Colleges Online Conference - Trends and Issues in Online Instruction. April 1-3, 1997. Toronto, Ontario. Disponível em:

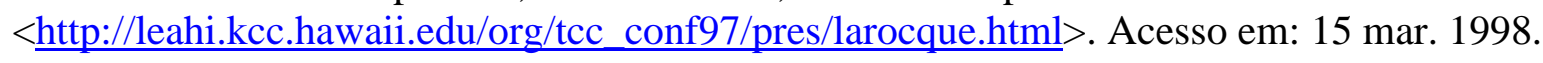

LEFFA, V. J. O ensino de línguas estrangeiras nas comunidades virtuais. In: IV SEMINÁRIO DE LÍNGUAS ESTRANGEIRAS, 2001, Goiânia. Anais do IV Seminário de Línguas Estrangeiras... Goiânia: UFG, 2002. v. 1, p. 95108.

Disponível em: 〈http://www.leffa.pro.br/comunidades.htm>. Acesso em 10 mar. 2003. 
LEMOS, A. Agregações Eletrônicas ou Comunidades Virtuais - Análise das Listas Falcom e Cibercultura. Publicação do Ciberpesquisa - Centro de Estudos e Pesquisas em Cibercultura. 404nOt FOund, ano 1,v. 1, n.14, março/2002. Disponível em: <http://www.facom.ufba.br/ciberpesquisa/404nOtFOund>. Acesso em 20 jun. 2002.

. Olhares sobre a Cibercultura. Cibercultura. Alguns pontos para compreender a nossa época. CUNHA, P. (orgs). Sulina, Porto Alegre, 2003; pp. 11-23. Disponível em:

<http://www.facom.ufba.br/ciberpesquisa/andrelemos/cibercultura.pdf >. Acesso em: 10 jul. 2004.

LÉVY, P. A inteligência coletiva: por uma antropologia do ciberespaço. Trad. Luiz P. Rouanet. São Paulo: Loyola, 1998a.

As tecnologias da inteligência: o futuro do pensamento na era informática. 6. reimp., Trad. Carlos Irineu da Costa. São Paulo: Editora 34 Ltda, 1998b.

Cibercultura. 1.ed. Trad. Carlos Irineu da Costa. São Paulo: Editora 34, 1999. (Coleção TRANS).

O que é o Virtual. 2. reimp., Trad. Paulo Neves. São Paulo: Editora 34 Ltda, $1998 \mathrm{c}$.

As Inteligências Coletivas. SESC, São Paulo. Disponível em:

〈http://www.sescsp.com.br/sesc/hotsites/pierre_levy/Conferencia.doc $>$. Acesso em: 20 nov. 2002.

LEVY, P.; AUTHIER, M. As Árvores de Conhecimentos. 2. ed. Trad. Monica M. Seineman. São Paulo: Editora Escuta, 2000.

LOBO SIERRA, A. et al. Empatia. [19--]. Disponível em <http://www.udec.cl/ clbustos/apsique/soci/empatia.html >. Acesso em 05 jan. 2002.

LÜDKE, M.; ANDRÉ, M. E. D. A. Pesquisa em educação: abordagens qualitativas. São Paulo: EPU, 1986.

LUKOWIECKI, A. L. S. Aprendizagem Baseada na Web: A Perspectiva do Aluno. In: VI CONGRESSO INTERNACIONAL DE EDUCAÇÃO A DISTÂNCIA, 1999, Rio de Janeiro. Texto da Biblioteca Online da ABED... Rio de Janeiro: ABED, 1999. Disponível em: http://www.abed.org.br/antiga/htdocs/paper_visem/adelaide_leticia_saad_lukowiecki.htm>.

Acesso em: 10 ago. 2000.

LUMSDEN, L. S. Student Motivation To Learn. ERIC DIGEST, n. 92, 1994. Disponível em: <http://www.ericfacility.net/databases/ERIC_Digests/ed370200.html>. Acesso em: 13 fev. 2004. 
MACMILLAN PUBLISHERS LTD. The Communicative Classroom. The One Stop Magazine - The magazine for English Language Teachers. Disponível em: $\langle$ http://www.onestopenglish.com/News/Magazine/Archive/comclass.htm>. Acesso em: 10 jan. 2004.

MAÇADA, D. L.; TIJIBOY, A.V. Aprendizagem Cooperativa em Ambientes Telemáticos. In: IV CONGRESSO IBERO-AMERICANO DE INFORMÁTICA NA EDUCAÇÃO, Brasília, out., 1998. [mensagem pessoal]. Mensagem recebida por <vcqm@uol.com.br>em 02 jun. 2001.

MARCELO, A. S. Internet e as Novas Formas de Sociabilidade. 2001. 159 p. Dissertação de Mestrado em Ciências da Comunicação. Universidade da Beira Interior, Covilhã, Portugal. Disponível em: $<$ http://www.bocc.ubi.pt/pag/marcelo-ana-sofia-internetsociabilidade.pdf>. Acesso em: 25 abr. 2004.

McCOMBS, B. L. Understanding the Keys to Motivation to Learn. [19--]. Mid-continent Research for Education and Learning. Disponível em:

〈http://www.mcrel.org/products/noteworthy/noteworthy/barbaram.asp〉. Acesso em: 10 nov. 2002.

MOORE, M. G. Teoria da Distância Transacional. In Keegan, D. (Ed.) Theoretical Principles of Distance Education. London, New York: Routledge, 1993 p. 22-38. Trad. Wilson Azevedo, com autorização do autor. Rev. de trad. José Manuel da Silva. Rio de Janeiro, setembro de 2002. Disponível em:

$<$ http://www.abed.org.br/publique/cgi/cgilua.exe/sys/start.htm?infoid=23\&sid=69\&UserAc tiveTemplate=2ing) $>$. Acesso em: 22 mar. 2004.

MORAN, J. M. Como Utilizar a Internet na Educação. 1997. Disponível em: 〈http://www.eca.usp.br/prof/moran/textos.htm>. Acesso em: 13 set. 2000.

. Educar o educador. [19--?]. Disponível em:

〈http://www. eca.usp.br/prof/moran/educar.htm>. Acesso em: 28 abr. 2002.

MORAN, J. M; MASETTO, M.; BEHRENS, M. Novas tecnologias e mediação pedagógica. Campinas, SP: Papirus Editora, 2000. (Coleção: Papirus Educação).

MORIN, E. Os Sete Saberes Necessários à Educação do Futuro. Trad. de Catarina Elionora F. da Silva e Jeanne Sawaya, ver. téc. de Edgard de Assis Carvalho. SP: Cortez, Brasília, DF: UNESCO, 2000.

MORRIS, W. Editor (1975). The American Heritage Dictionary of the English Language. Published by A. H. Publishing Co., Inc. and Houghton Mifflin Company.

OIC- THE OFFICE OF INSTRUCTIONAL CONSULTATION. Differences between Collaborative and Cooperative Learning. Disponível em:

<http://www.id.ucsb.edu/IC/index.html〉. Acesso em: 04 mar. 2002. 
PANITZ, T. A definition of Colaborative vs Cooperative learning. 1996. Disponível em: <http://www.lgu.ac.uk/deliberations/collab.learning/panitz2.html >. Acesso em: 04 jul. 2002.

. Collaborative versus Cooperative Learning - A comparison of the two concepts which will help us understand the underlying nature of interactive learning. [19--].

Disponível em: 〈http://home.capecod.net/ tpanitz/tedsarticles/coopdefinition.htm>. Acesso em: 04 ago. 2002.

PALLOFF, R. M. \& PRATT, K. Building Learning Communities in Cyber-space: Effective Strategies for the Online Classroom. S.Francisco: Jossey-Brass Publishers, 1999.

PAULSEN, M. F. Moderating Educational Computer Conferences. Published in Berge, Z. L. \& Collins, M. P. (Eds.). Computer-mediated communication and the on-line classroom in Distance Education. Cresskill, NJ: Hampton Press, 1995. Used by permission of the Publisher. Disponível em: <http://www.emoderators.com/moderators/morten.html>. Acesso em: 20 mar. 2003.

PENTEADO, H.D. Meio ambiente e formação de professores: considerações metodológicas. In: Meio ambiente e formação de professores. 5. ed. São Paulo: Cortez, 2003. cap. IV, p. 52-64.

2002.

Comunicação Escolar: Uma Metodologia de Ensino. São Paulo: Ed. Salesiana, . Televisão e Escola: Conflitos ou cooperação? 2. ed. São Paulo: Cortez, 1999.

Pedagogia da comunicação: sujeitos comunicantes. In: PENTEADO, H. D. (org). Pedagogia da Comunicação: Teorias e Práticas. Rev. Maria de Lourdes de Almeida. São Paulo: Cortez Editora, 1998, p. 13-22.

PERRENOUD, P. Dez novas competências para ensinar. Trad. Patrícia Chittoni Ramos, Porto Alegre: Artes Médicas Sul, 2000.

PREECE, J. Empathic Communities: Reaching out across the Web. Interactions, March 1998a. Disponível em:

<http://www.ifsm.umbc.edu/communities/Interactionsfinal.html>.Acesso em: 25 abr. 2004.

. Empathic Communities: Balancing Emotional and Factual Communication.

Interacting with Computers, 1998b. Disponível em:

<http://www.ifsm.umbc.edu/communities/IwCPreece2.html >. Acesso em: 25 abr. 2004.

REID, E. M. Cultural Formation in Text-Based Virtual Realities. Cultural Studies

Program Master's Thesis. University of Melbourne, 1994. Disponível em:

<http://people.we.mediaone.net/elizrs/cult-form.html> Acesso em: 10 jun. 1999. 
RHEINGOLD, H. The Virtual Community: Homesteading on the Eletronic Frontier. Original em inglês na íntegra. Originalmente publicado em 1993. Disponível em: <http://www.rheingold.com> Acesso em: 15 maio 1999.

RIVERS, W. M. Principle 1.: The student is the language learner. Principles of Interactive Language Teaching. 1997. Disponível em: <http://agoralang.com/rivers/10Principles_1.html>. Acesso em 26 maio, 2004.

RODGERS, T. S. Language Teaching Methodology. ERIC Clearinghouse on Languages and Linguistics. Digest. Issue Paper, Sep. 2001. Disponível em:

<http://www.cal.org/resources/digest/rodgers.html>. Acesso em: 29 maio 2004.

ROGERS, C. R. Um jeito de ser. Trad. Maria Cristina Machado Kupfer, Heloísa Lebrão, Yone Souza Patto. Rev. Trad. Maria Helena Souza Patto. São Paulo: EPU, 1983.

SANTOS, J.A. Metodologia científica. São Paulo: Futura, 1998, p. 108.

SILVA ROSADO, E. M. da; SOUZA ROMANO, M. C. J. de. O Vídeo no Campo da Educação. Ijuí: Editora UNIJUÍ, 1993.

SILVIO, J. Las Comunidades Virtuales como conductoras del aprendizaje permanente. In: SIMPÓSIO SOBRE "Sistemas de Aprendizaje Virtual", Caracas, nov., 1999. Organizado por la Red Iberoamericana de Informática Educativa (RIBIE), el Centro Internacional de Educación y Desarrollo (CIED) de la Compañía Petróleos de Venezuela y el

IESALC/UNESCO. Disponível em:

<http://funredes.org/mistica/english/cyberlibrary/participants/docuparti/doc35.html >. Acesso em: 02 de jan. 2004.

SOUZA, T. R. P de; SAITO, C.H. A centralidade do planejamento na elaboração de material didático para EAD. In: VI CONGRESSO INTERNACIONAL DE EDUCAÇÃO A DISTÂNCIA,1999. Texto da Biblioteca Online da ABED... Rio de Janeiro: ABED, 1999. Disponível em:

<http://www.abed.org.br/antiga/htdocs/paper_visem/thelma_rosane_de_souza.htm>. Acesso em: 10 ago. 2000.

TINZMANN, B.F. et al. What is the Collaborative Classroom. 1990. Disponível em: <http://www.ncrel.org/sdrs/areas/rpl_esys/collab.htm>.Acesso em: 04 set. 2002.

THE AMERICAN HERITAGE DICTIONARY. 3rd edition, version 3.6a. SoftKey International Inc., 1994. CD-Rom.

TORI, R. Tecnologias Interativas para a Educação SEM Distância. 2000. Artigo disponibilizado na Plataforma de Gerenciamento de Cursos On-line WebCT, no curso "Tecnologias para uma Educação Virtual Interativa", 2 semestre, 2001. 
TU, Chih-Hsiung. \& CORRY, M. Research in Online Learning. E-JIST, v. 5, n. 1, 2001. Disponível em: 〈http://www.usq.edu.au/electpub/e-jist/docs/html2002/chtu_frame.html〉. Acesso em: 10 fev. 2003.

WILSON, B. G. Sense of community as a valued outcome for electronic courses, cohorts, and programs. VisionQuest PT3 Conference, Denver, July 2001. Disponível em: <http://carbon.cudenver.edu/ bwilson/SenseOfCommunity.html $>$. Acesso em: 06 jun. 2003. 


\section{Bibliografia}

ALCÂNTARA, P. R.; BEHRENS, M. A. Caminhos do Saber: Aprendizagem Colaborativa com Tecnologias Interativas. In: ROMANOWSKI, J. P.; MARTINS, P. L. O.; JUNQUEIRA, S. R. A. (Orgs.). Conhecimento Local e Conhecimento Universal: Diversidade, Mídias e Tecnologias na Educação. Curitiba: Champagnat, 2004, v. 2, cap. XXI, p. 267-288.

ALVES, M. P. C. A avaliação e o desenvolvimento profissional do professor. In: MOREIRA, A. F. B. \& MACEDO, E. F. de (orgs.). Currículo, Práticas Pedagógicas e Identidades. Rev. Maria Cecília Gomes Barbosa Moreira. Porto Editora, Lda, Portugal, 2002. cap. 7, p. 138-159.

ANDRÉ, M. E. D.A. A pesquisa no cotidiano escolar. In: FAZENDA, I. (org.). Metodologia da Pesquisa Educacional. São Paulo: Cortez, 2.ed. aumentada, 1991, p. 3545 .

BELLONI, M. L. Educação a distância. 2.ed. Campinas, S.P: Autores Associados, 2001. (Coleção educação contemporânea).

A Integração das Tecnologias de Informação e Comunicação aos Processos Educacionais. In: BARRETO, R. G. (org.). Tecnologias educacionais e educação a distância: avaliando políticas e práticas. Rio de Janeiro: Quartet, 2001. Parte I, p. 54-73.

BENTZ-CLUCAS, B. Local Route to the Info Superhighway: How School Can Forge Community Links. TECH TRENDS, mar., 21-26, 1996.

BRUNO, A. R. A Linguagem Emocional: tecendo a Razão e a Emoção nos cursos de formação em ambientes telemáticos. GT16 de Educação e Comunicação, 2000, p.75-94.

CASTRO, A. D. de; CARVALHO, A. M. P. de (orgs.). Ensinar a Ensinar. Didática para a Escola Fundamental e Média. Rev. Janice Yunes. São Paulo: Pioneira Thomson Learning, 2001.

CHERNY, L. "The situated behavior of MUD back channels" AAAI Spring Symposium, Stanford, 1995b.

CORTELAZZO, I. B.C. Ambientes de Aprendizagem Otimizados pela Tecnologia Educacional. In: ROMANOWSKI, J. P.; MARTINS, P. L. O.; JUNQUEIRA, S. R. A. (Orgs.). Conhecimento Local e Conhecimento Universal: Diversidade, Mídias e Tecnologias na Educação. Curitiba: Champagnat, 2004, v. 2, cap. XX , p. 255-266 . 
DRISCOLL, M. Web-based Training: Using Technology to Design Adult Learning Experiences. San Francisco: Jossey-Bass/Pfeiffer, 1998.

FALSETTI, J. What the Heck is a MOO? ESL in Higher Education Newsletter, 14 (2), 1995.

FANDERCLAI, T.L. MUDS in education: new environments, new pedagogies. Computer-Mediated Communication Magazine, v. 2, $\mathrm{n}^{\circ}$. 1, Jan. 1995, 8.

FAZENDA, I. C. A. Dificuldades comuns entre os que pesquisam educação. In: FAZENDA, I. (org). Metodologia da Pesquisa Educacional. São Paulo: Cortez, 2.ed. aumentada, 1991, p. 11-20.

A. Reflexões metodológicas sobre a tese: "Interdisciplinaridade - um projeto em parceria". In: FAZENDA, I. (org). Metodologia da Pesquisa Educacional. São Paulo: Cortez, 2.ed. aumentada, 1991, p. 145-162.

GARRIDO, E. Pesquisa Universidade - Escola e Desenvolvimento Profissional do Professor. 2000. 111 p. Tese de Livre-Docência em Educação. Faculdade de Educação, Universidade de São Paulo.

GATES, B.; MYHRVOLD, N.; RINEARSON, P. A estrada do futuro. Trad. Beth Vieira, et al., supervisão técnica Ricardo Rangel. São Paulo: Companhia das Letras, 1995.

HENDERSON, B. Part Three: The Fifth Componet and The Sixth Component. In: The Components of Online Education: higher education on the Internet. Occasional papers series. Centre for the Study of Co-operatives. University of Saskatchewan, LOCAL: Canada, 1999, p. 53-58

HILL, J.R.; THARP, D. SINDT, K.; JENNINGS, M. \& THARP, M. Collaborative Web Site Design from a Distance: Challenges and Rewards. TECH TRENDS, mar., 1997, p. 31-37.

KENSKI, V. M. Ensinando em Ambientes Virtuais: Relato sobre o planejamento de uma disciplina semi-presencial em curso de pós-graduação. In: ROMANOWSKI, J. P.; MARTINS, P. L. O.; JUNQUEIRA, S. R. A. (Orgs.). Conhecimento Local e Conhecimento Universal: Diversidade, Mídias e Tecnologias na Educação. Curitiba: Champagnat, 2004, v. 2, cap. XVIII, p. 229-244.

O Papel do Professor na Sociedade Digital. In: DOMINGUES DE CASTRO, A. \& PESSOA DE CARVALHO, A. M. (orgs.). Ensinar a Ensinar. Didática para a Escola Fundamental e Média. São Paulo: Pioneira Thomson Learning, 2001. cap. 5, p. 95-106.

. Em Direção a uma Ação Docente Mediada pelas Tecnologias Digitais. In: BARRETO, R. G. (org.). Tecnologias educacionais e educação a distância: avaliando políticas e práticas. Rio de Janeiro: Quartet, 2001. Parte I, p. 74-84. 
KRASHEN, S. D. Principles and Practice in Second Language Acquisition. Pergamon Press, Inc. 1981.

LA TAILlE, Y. de; OLIVEIRA, M. K. de; DANTAS, H. Piaget, Vygotosky, Wallon: teorias psicogenéticas em discussão. São Paulo: Summus, 1992.

LUNA, S. V. de. O falso conflito entre tendências metodológicas. In: FAZENDA, I. (org). Metodologia da Pesquisa Educacional. São Paulo: Cortez, 2.ed. aumentada, 1991, p. 2133.

MAFFESOLI, M. A Comunidade Emocional - Argumentos de uma Pesquisa; A Socialidade Contra o Social; O Tribalismo. In: O tempo das Tribos: O declínio do individualismo nas sociedades de massa. Apr. Luiz Felipe Baeta Neves; trad. Maria de Lourdes Menezes; rev. téc. Arno Vogel. 2. ed. Rio de Janeiro: Forense Universitária, 1998. cap. I, p. 13 - 43; cap. III, p. 79 - 99; cap. IV, p. 100 - 142.

MAIA, C. Guia brasileiro de educação a distância. São Paulo: Ed. Esfera, 2001.

MARTINS, J. A pesquisa qualitativa. In: FAZENDA, I. (org). Metodologia da Pesquisa Educacional. São Paulo: Cortez, 2.ed. aumentada, 1991, p. 47-58.

MARTINS, G. de A. Manual para elaboração de monografias e dissertações. São Paulo: Atlas, 2. ed., 2000.

MATOS, F. G. de. Lingüística Aplicada ao ensino de inglês. McGraw-Hill do Brasil, 1976.

McCLEARY, L. E. Aspectos de uma Modalidade de Discurso Mediado por Computador. 1996. 235p. Tese de Doutoramento apresentada ao Departamento de Lingüística da Faculdade de Filosofia, Letras e Ciências Humanas, Universidade de São Paulo.

MIZUKAMI, M. G. N. Ensino: as abordagens do processo. São Paulo: EPU, 1986 (Temas básicos de educação e ensino).

MORAN, J.M. Os Novos Espaços de Atuação do Professor com as Tecnologias. In: ROMANOWSKI, J. P.; MARTINS, P. L. O.; JUNQUEIRA, S. R. A. (Orgs.). Conhecimento Local e Conhecimento Universal: Diversidade, Mídias e Tecnologias na Educação. Curitiba: Champagnat, 2004, v. 2, cap. XIX, p. 245-254.

. Mudanças na comunicação pessoal: gerenciamento integrado da comuni-cação pessoal, social e tecnológica. São Paulo: Paulinas, 1998. (Coleção: Comunicação e estudos) Novas tecnologias e o reencantamento do mundo. In: Tecnologia Educacional, Rio de Janeiro, vol. 23, nº. 126, set. /out., p. 24-26, 1995. 
MORIN, E. Cruzada de Heróis Anônimos pelo Planeta. O Estado de São Paulo, São Paulo, Caderno 2/Cultura, D11, 4/2/2001.

NOLAN, J. Research into Educational Computer Mediated Communication. Paper submitted as part of his Doctoral Comprehensive exams in December, 1995.

NORONHA, O. M. Pesquisa participante: repondo questões teórico-metodológicas. In: FAZENDA, I. (org). Metodologia da Pesquisa Educacional. São Paulo: Cortez, 2.ed. aumentada, 1991, p. 137-143.

PÁDUA, E. M. M de. Metodologia da pesquisa: Abordagem teórico-prática. 6.ed. ver.e ampl. Campinas, SP: Papirus, 2000. (Coleção Magistério: Formação e Trabalho Pedagógico).

PALLOFF, R. M. \& PRATT, K. Lessons from the Cyberspace Classroom: The Realities of Online Teaching. Jossey-Brass Inc., 2001.

PIAGET, J. Capítulo VI - Os fatores sociais do desenvolvimento intelectual. In: Psicologia da Inteligência. Trad. Egléa de Alencar, Rio de Janeiro: Editora Fundo de Cultura S. A., 1967.

PUENTES, M. O ensino centrado no estudante; Atitudes e técnicas: reformulação da não diretividade. In: $\mathbf{O}$ ensino centrado no estudante: renovação e crítica das teorias de Carl R. Rogers. São Paulo: Cortez \& Moraes, 1978. cap. I, p. 7-24; cap. IV, p. 67-84.

SANTOS, E. T. ; RODRIGUES, M. Educação á Distância - Conceitos, Tecnologias, Constatações, Presunções e Recomendações. São Paulo: EPUSP, 1999, 32p.

SEVERINO, A. J. Diretrizes para a elaboração de uma monografia científica; Observações motodológicas referentes aos trabalhos de pós-graduação. In: Metodologia do trabalho científico: diretrizes para o trabalho didático-científico na Universidade. 10. ed. São Paulo, Cortez Editora e autores Associados, 1984. cap. V, p.109-150; cap. VI, p.151-169.

SHERRY, L. \& The Internet Task Force. Supporting a Networked Community of Learners. TECH TRENDS, oct., p. 28-32, 1996.

SILVA, B. D. da. A inserção das tecnologias de informação e comunicação no currículo. Repercussões e exigências na profissionalidade docente. In: MOREIRA, A. F. B.; MACEDO, E. F. de (orgs.). Currículo, Práticas Pedagógicas e Identidades. Rev. Maria Cecília Gomes Barbosa Moreira. Porto Editora, Lda, Portugal, 2002. cap. 4, p. 65-91.

SILVA, A. M. A. C. de. Pensamento poder e sociabilidade on-line e off-line. In:

Reconectando a sociabilidade on-line e off-line: trajetórias, formação de grupos e poder em canais geográficos no Internet Relay Chat (IRC). Universidade Estadual de Campinas, Instituto de Filosofia e Ciências Humanas. Campinas, S.P., 2000, cap. I, p. 13-36. 
SIMONSON et al. Chapter 2: Definitions, History, and Theories of Distance Education. In: Teaching and learning at a distance: foundations of distance education. Prentice-Hall, Inc., Pearson Education, 2000, p.19-48.

TORRES, P. L. Universidade Virtual: da Experiência Global ao Matice da PUCPR. In: ROMANOWSKI, J. P.; MARTINS, P. L. O.; JUNQUEIRA, S. R. A. (Orgs.). Conhecimento Local e Conhecimento Universal: Diversidade, Mídias e Tecnologias na Educação. Curitiba: Champagnat, 2004, v. 2, cap. XXII, p. 289-301.

TURBEE, L. Mooing in a foreign language: how, why, and how? Paper written for the Information Technology Education Connection's International Virtual Conference/ Exhibition on Schooling and the Information Superhighway, 1996, jun. 3-9 at the Center for Teacher Librarian, Charles Stuart University.

ULINE, C.L. Knowledge in Information Age: Effortless Communication and the Effort of Reflective Thought. Educational Technology, 1996, sep./oct., p. 29-32.

VYGOTSKY, L. S. A formação social da mente: o desenvolvimento dos processos psicológicos superiores. COLE, M. et al. (orgs.). trad. José Cipolla Neto, Luis Silveira Menna Barreto, Solange Castro Afeche. 4.ed. São Paulo: Martins Fontes, 1991. 


\section{W ebgrafia}

ANDERSON, T. Toward a Theory of Online Learning. In: Theory and Practice of Online Learning. ANDERSON, T. \& ELLOUMI, F. (Ed.). Athabasca University, 2004. Part 1, chap. 2. Disponível em: <cde.athabascau.ca/online_book/>. Acesso em: 05 jun. 2004.

AZEVÊDO, W. Panorama Atual da Educação a Distância no Brasil, 2000. Disponível em: <http://www.aquifolium.com.br/educacional/artigos/panoread.html > . Acesso em: $10 \mathrm{dez}$. 2001.

BARNES, A. \& THAGARD, P. Empathy and Analogy. 1997. Disponível em: <http://cogsci.uwaterloo.ca/Articles/Pages/Empathy.html>. Acesso em: 17 jan. 2002.

BARROS, D. M. V. Formação de professores para educação a distancia: elementos na construção de uma didática digital. In: X CONGRESSO INTERNACIONAL DE EDUCAÇÃO A DISTÂNCIA, 2003, Porto Alegre. Texto da Biblioteca Online da ABED... Porto Alegre: ABED, 2003. Disponível em:

<http://eventos.ead.pucrs.br/x_congresso_abed/docs/anais/TC62.htm>. Acesso em: 13 out. 2003.

BAUMAN, M. Online Learning Communities. [19--]. Disponível em: <http://leahi.kcc.hawaii.edu/org/tcc_conf97/pres/bauman.html>. Acesso em: 10 nov. 1998.

BENSUSAN, G. In Praise of Learners. Ed at a Distance: Magazine and Ed Journal. v. 15, n. 7, July 2001. Disponível em:

<http://www.usdla.org/html/journal/JUL01_Issue/article09.html >. Acesso em: 04 maio 2002.

BIRCH, D. Competências necessárias para um aluno bem-sucedido no ambiente de eLearning. E-Learning Brasil News. Ano 2, n. 20, nov. 2002. Disponível em: <http://www.elearningmag.com/elearning/>. Acesso em: 2 dez. 2002.

BORGES, R. M. de A.; FERREIRA, M. M. S. Vivendo e aprendendo - uma experiência de formação docente para atuar em educação a distância online. In: X CONGRESSO INTERNACIONAL DE EDUCAÇÃO A DISTÂNCIA, 2003, Porto Alegre. Texto da Biblioteca Online da ABED... Porto Alegre: ABED, 2003. Disponível em: <http://eventos.ead.pucrs.br/x_congresso_abed/docs/anais/TC111.htm>. Acesso em: 13 out. 2003.

BRNA, P. Modelos de Colaboração. Trad. Álvaro de Azevedo Diaz, rev. téc. Raul Sidnei Wazlawick. Original em inglês publicado nos Anais do IV WIE, Congresso da SBC, 1998. Traduzido e publicado com permissão do autor e editor. Disponível em:

<http://www.inf.ufsc.br/sbc-ie/revista/nr3/Brna03.htm>. Acesso em: 30 jun. 2002. 
BROOKS, R. The Importance of Empathy: A Significant Feature of the Mindset of Successful People. Part I. February, 1999. Disponível em:

<http://www.drrobertbrooks.com/writings/articles/9901.html>. Acesso em: 20 jun. 2004.

BROWN, A. Designing for Learning: What are the essential features of an effective online course? Australian Journal of Educational Technology, 13(2), 1997, pp. 115-126 Disponível em: <http://www.emoderators.com/moderators/brown.html>. Acesso em: 28 mar. 2004.

BRUCKMAN, A. Identity workshop: emergent social and psychological phenomena in text-based virtual reality, 1992. Disponível em:

<http://www.cc.gatech.edu/ asb/old/papers-index-deco1.html>. Acesso em: 20 ago. 1999.

CALIFORNIA DISTANCE LEARNING PROJECT. What's Distance Learning. [19--]. Disponível em: 〈http://www.cdlponline.org/dlinfo/cdlp1/distance/home.html >. Acesso em: 10 out. 2001.

CAMPBELL, T. The first email message - Who sent it and what it said. [20--?]. Pretext Magazine. Disponível em: http://www.pretext.com/mar98/features/story2.htm. Acesso em: 10 jul. 2002.

CASTELLS, M. Internet \& la Sociedad Red. 1999. Aula inaugural do programa de doutorado sobre la sociedad de la información y el conocimiento (UOC). Disponível em: <http://www.forum-global.de/soc/bibliot/castells/InternetCastells.htm>. Acesso em: 12 maio 2003.

CASTRO, M. A. S.de. Introdução à Netiqueta. Versão resumida do texto "Netiqueta - Guia de Boas Maneiras na Internet”. Novatec Editora. 1997. Disponível em: http://www.icmc.sc.usp.br/manuals/BigDummy/netiqueta.html. Acesso em: 10 jul. 2002.

CHAVES, E. Conceitos Básicos. 1999. Disponível em: $\langle$ http://www.edutecnet.com.br/Tecnologia\%20e\%20Educacao/edconc.htm >. Acesso em: 10 out. 2001.

CHESTER, A. \& GWYNNE, G. Online Teaching: Encouraging Collaboration through Anonymity. Journal of Computer-Mediated Communication. v. 4(2), dec. 98. Disponível em: 〈http://jcmc.huji.ac.il/vol4/issue2/chester.html >. Acesso em: 25 jul. 2002.

CHRISTIANSEN, E. \& DIRCKINCK-HOLMFELD, L. Making Distance Learning Collaborative. [19--]. Disponível em: 〈http://www-csc195.indiana.edu/csc195/christia.html〉. Acesso em: 20 ago. 1997. 
COSTA, L. F. As comunidades virtuais e um paralelo com as comunidades na modernidade e as comunidades na tradição. 2001. Disponível em:

〈http://www.facom.ufba.br/ciberpesquisa/seminario/leonardo.htm〉. Acesso em: 20 mar. 2004.

COUTO, E.; FONSECA, D. Comunidade Virtual: herança cultural ou tendência contemporânea? UFBA/FACED, Programa de Pós Graduação em Edu, Dep. de Edu II, EDC708: Educação e Tecnologias Contemporâneas. Disponível em: $\langle$ http://twiki.im.ufba.br/bin/view/EDC708/ComunidadesVirtuais〉. Acesso em 14 jun. 2004.

DAL MAGO, D.; LUZ, E. F. ; FERREIRA, R. de C. M. O ambiente virtual como suporte para o ensino de língua portuguesa. In: X CONGRESSO INTERNACIONAL DE EDUCAÇÃO A DISTÂNCIA, 2003, Porto Alegre. Texto da Biblioteca Online da ABED... Porto Alegre: ABED, 2003. Disponível em: 〈http://eventos.ead.pucrs.br/x_congresso_abed/docs/anais/TC100.htm>. Acesso em: 14 out. 2003.

FEENBERG, A. The written world: On the theory and practice of computer conferencing. Book chapter, evaluative report in R. Mason \& A. Kaye (Eds.) Mindweave: communication, computers and distance education. Oxford: Pergamon Press, 1989, p. 22-39. Disponível em: <www-rohan.sdsu.edu/faculty/feenberg/Writworl.htm〉. Acesso em 30 maio 2004.

FENG, J., LAZAR, J. \& PREECE, J. Empathy and online interpersonal trust: A fragile relationship. Behavior and Information Technology (accepted in press), 2004. Disponível em: 〈http://www.is.umbc.edu/ preece/Papers/trust_paper_BIT2.pdf〉 . Acesso em: 10 mar., 2004.

GARDNER, H. Interview with Howard Gardner. NEA (National Education Association). March, 1999. Disponível em: 〈http://www.nea.org/neatoday/9903/gardner.html〉. Acesso em: 20 maio, 2004.

GOKHALE, A. Collaborative Learning Enhances Critical Thinking. Journal of Technology Education, v. 7, n.1, fall 1995. Disponível em: $<$ http://scholar.lib.vt.edu/ejournals/JTE/jte-v7n1/gokhale.jte-v7n1.html $>$. Acesso em: 02 jul. 2002.

HARASIM, L. et al. Learning Networks. A field guide to teaching and learning online. Cambridge: MIT Press, 1995. (Síntese, tradução e comentários de Wilson Azevêdo, wilsonazevedo@aquifolium.com.br)

HILL, J. R., \& RAVEN, A. Online learning communities: If you build them, will they stay? ITFORUM. Paper n. 46, 2000. Disponível em:

<http://it.coe.uga.edu/itforum/paper46/paper46.htm>. Acesso em: 06 jun. 2004. 
HILTZ, S. R. Collaborative Learning in Asynchronous Learning Networks: Building Learning Communities. WEB98, 1998. Disponível em:

<http://eies.njit.edu/ hiltz/collaborative_learning_in_asynch.htm>. Acesso em: 02 ago. 2002.

HILTZ, S. R. et al. Measuring the Importance of Collaborative Learning for the Effectiveness of ALN: A Multi-Measure, Multi-Method Approach. JALN, v. 4:2, Sept, 2000. Disponível em: <http://www.aln.org/alnweb/journal/Vol4_issue2/le/hiltz/lehiltz.htm>. Acesso em: 07 ago. 2002.

HOTER, E. A Model For Learning How To Teach Advanced Literacy Skills Via Computer Mediated Communication. 2001. Degree of Doctorate in Philosophy. Submitted to the Senate of the Hebrew University, Israel. Disponível em: <http://www.talpiot.ac.il/elaine/index.htm>. Acesso em: 05 jun. 2002.

KAPLAN, S. Desenvolver Comunidades, uma estratégia para o Aprendizado Colaborativo. e-Learning Brasil News. Ano 2, n.18, set.2002. Disponível em: <http://www.elearningbrasil.com.br/news/news18/artigo_1.asp. $>$. Acesso em: 22 out. 2002.

KENSKI, V.M. Processos de Interação no Ensino Mediado por Tecnologias. Artigo disponibilizado na Plataforma de Gerenciamento de Cursos On-line WebCT, no curso "Ensinando em Ambientes Virtuais I", 1º semestre, 2002.

KERCKHOVE, D. de. The Information Management Round Table - Connected Intelligence. May 4, 1999. Disponível em: 〈http://www.iog.ca/publications/it_table6.pdf $>$. Acesso em: 19 fev. 2004.

KLEMM, W. R. \& SNELL, J. R. Enriching Computer-Mediated Group Learning by Coupling Constructivism with Collaborative Learning. Journal of Instructional Science and Technology, artigo 1, v. 1, n.2, mar. 1996. Disponível em: $\langle$ http://www.usq.edu.au/electpub/e-jist/docs/old/vol1no2/article1.htm〉. Acesso em: 06 ago. 2002.

KNUTSON, E. K. Reading with a Purpose: Communicative Reading Tasks for the Foreign Language Classroom. Cal Digests on foreign language education. Dec. 1998, EDO-FL-9813. Disponível em: 〈http://www.cal.org/resources/digest/reading_digest.html〉. Acesso em: 20 mar. 2004.

LACOMBE, I. A. Navegando e aprendendo: reflexões sobre um curso de inglês via rede mundial de computadores. 2000. 111 p. Dissertação de Mestrado em Lingüística Aplicada. Pontifícia Universidade Católica - São Paulo. Disponível em: 〈http://lael.pucsp.br/lael/teses/tese_bel.zip〉. Acesso em: 27 maio 2004. 
LEMOS, A. Ciber-Socialidade. Tecnologia e Vida Social na Cultura Contemporânea. Trabalho apresentado no GT Sociedade Tecnológica, no COMPÓS-98. Revista Logos, Rio de Janeiro: UERJ, 1998. [on-line] Disponível em <http://www.facom.ufba.br/pesq/cyber/lemos/cibersoc.html>. Acesso em 20 jun. 2003.

O Sujeito e os Chats: Preposições para uma herança moderna na pós-modernice. Publicação do Ciberpesquisa - Centro de Estudos e Pesquisas em Cibercultura. 404nOt FOund, ano 1,v. 1, n.13, 2001- fev/2002. Disponível em: 〈http://www.facom.ufba.br/ciberpesquisa/404nOtFOund $>$. Acesso em: 20 jun. 2002.

LEVY, P. Educação e Cybercultura. [199-]. In:Cybercultura. Disponível em: 〈http://www1.portoweb.com.br/pierrelevy/educaecyber.html>. Acesso em: 01 out. 1999.

LYMAN, P. O projeto das comunidades virtuais [19--]. Trad. Magda Lopes.

Disponível em: 〈http://www.ime.usp.br/ is/infousp/lyman.htm〉. Acesso em: 10 ago. 2001.

MASIE, E. Metodologias de Aprendizagem Essenciais para o e-Learning. e-Learning Brasil News. Ano 1, n.1, jan. 2001. Disponível em: <http://www.elearningbrasil.com.br/news/artigos/art01.asp〉. Acesso em: 22 out. 2001.

MASON, R. Models of Online Courses. ALN Magazine. V. 2, issue 2, 1998. Disponível em: 〈http://www.aln.org/publications/magazine/v2n2/mason.asp $>$. Acesso em: 17 jun. 2002 .

MORAN, J. M. Ensino e Aprendizagem Inovadores com Tecnologias. [199-]. Disponível em: 〈http://www.eca.usp.br/prof/moran/textos.htm>. Acesso em: 13 ago. 2000.

. Mudar a Forma de Ensinar e de Aprender. [199-]. Disponível em: 〈http://www.eca.usp.br/prof/moran/textos.htm>. Acesso em: 13 set. 2000.

. O que é educação a distância. [199-]. Disponível em:

〈http://www.eca.usp.br/prof/moran/textos.htm〉. Acesso em: 04 jul. 2002.

NITZKE, J.A. et al. Criação de Ambientes de Aprendizagem Colaborativa. In: X SBIE, nov. 99, Curitiba/PR. Disponível em:

<http://www.penta.ufrgs.br/pgie/sbie99/acac.html>. Acesso em: 05 abr. 2002.

NUNES, I. B. Noções de Educação a Distância. [199-]. Disponível em: <http://www.intelecto.net/ead/ivonio1.html >. Acesso em: 20 jun. 2001.

PAULSEN, M. F. Teaching methods and techniques for computer-mediated communication. [19--]. Disponível em: 〈http://home.nettskolen.nki.no/ morten/>. Acesso em: 10 ago. 2002. 
PESCE, L. ; ALEGRETTI, S. Educação a distância na formação de educadores. In: X CONGRESSO INTERNACIONAL DE EDUCAÇÃO A DISTÂNCIA, 2003, Porto Alegre. Texto da Biblioteca Online da ABED... Porto Alegre, ABED, 2003. Disponível em: $\langle$ http://eventos.ead.pucrs.br/x_congresso_abed/docs/anais/TC61.htm>. Acesso em: 13 out. 2003.

PINTO, D. What does 'schMOOze' mean? 1995. Disponível em: 〈http://www.latrobe.edu.au/WWW/Language/dave.html>. Acesso em: 10 jun. 1999.

PONTE, J. P. \& OLIVEIRA, H. Comunidades virtuais no ensino, na aprendizagem e na formação. [19-?]. Disponível em: <http://www.educ.fc.ul.pt/docentes/jponte/docs-pt/ 01Ponte-Oliveira(SPCE-Consol).doc >. Acesso em 10 jan. 2004.

PREECE, J.; MALONEY-KRICHMAR, D. \& ABRAS, C. History of Emergence of Online Communities. Draft. Versão final 2003 in press. In: B. Wellman (Ed.), Encyclopedia of Community. Berkshire Publishing Group, Sage. Disponível em: $\langle$ http://www.is.umbc.edu/ preece/paper/6\%20Final\%20Enc\%20preece\%20et\%20al.pdf $>$. Acesso em: 14 mar. 2004.

QUEIROZ, V. C. As tecnologias de Informação e Comunicação: abrindo novos caminhos para a educação. Disponível em: Biblioteca Jurídica Virtual, Projeto: Buscalegis ®, UFSC, set. 2004.

URL:

http://150.162.138.14/arquivos/As\%20Tecnologias\%20de\%20Informação\%20e\%20Comun icação\%20abrindo\%20novos\%20caminhos\%20para\%20a\%20educação.htm

. SchMOOze e sua aplicação no ensino de inglês como língua estrangeira. Disponível em: EAD, Unicamp, Revista Digital, jul. 2004.

URL: http://www.rau-tu.unicamp.br/nou-rau/ead/document/?code=46.

Disponível em: Almanaque Professor XXI, maio. 2004.

URL: URL:http://www.multirio.rj.gov.br/seculo21/generico.asp?id_tipo=4\&id_tbl_gen=1831

Disponível em: Estadão On-line, Seção: Educação, abr. 2004.

URL: http://www.estadao.com.br/educando/noticias/2004/abr/20/170.htm

. [ co-autoria: Pollyana N. Mustaro]. Uso pedagógico de ferramentas e serviços digitais gratuitos. Disponível em: Almanaque Professor XXI, jul. 2004.

URL: http://www.multirio.rj.gov.br/seculo21/generico.asp?id_tipo=5\&id_tbl_gen=1921

Aprimorando o inglês com auxílio do e-mail: Projeto Intercultural e Dicas para seu Sucesso. Disponível em: Almanaque Professor XXI, jan. 2004.

URL: http://www.multirio.rj.gov.br/seculo21/generico.asp?id_tipo=4\&id_tbl_gen=1833 
QUEIROZ, V.C. [co-autoria: Pollyana N. Mustaro]. O uso de serviços gratuitos da Web como ferramentas complementares no processo educativo. Disponível em: Almanaque Professor XXI, dez. 2003.

URL: http://www.multirio.rj.gov.br/seculo21/generico.asp?id_tipo=4\&id_tbl_gen=894

[co-autoria: Pollyana N. Mustaro]. Reflexiones sobre cursos online y profesores virtuales. Disponível em: La revista digital de e-learning de América Latina, Año 1, n. 25, nov. 2003.

URL: http://www.elearningamericalatina.com/edicion/noviembre2/na_2.php

. [co-autoria: Pollyana N. Mustaro]. Curso on-line: linguagens digitais na Sétima Arte. Disponível em: Monografia.com. Links: Educacion, 2003.

URL: http://www.monografias.com/trabajos14/lengdigitalcine/lengdigitalcine.shtml

. [co-autoria: Pollyana N. Mustaro]. Quem é o Professor do Século XXI? Disponível em: Estadão On-line, Seção: Educação, ago. 2003.

URL: http://www.estadao.com.br/artigodoleitor/htm/2003/ago/15/135.htm

. [co-autoria: Pollyana N. Mustaro]. New Competencies for the XXI Century Teachers. Disponível em: English \& Fun. Interviews and Opinions Section, ago. 2003. URL: http://www.welcometoenglishandfun.com/interviews/interviews.htm

. [co-autoria: Pollyana N. Mustaro]. Roles and Competencies of Online Teachers. Disponível em: Internet TESL Journal, Japão, v. IX, n. 7, July 2003.

URL: http://iteslj.org/Articles/Queiroz-OnlineTeachers.html

. [co-autoria: Pollyana N. Mustaro]. Um Olhar Pedagógico sobre o Trailer Digital. Disponível em: 404nOtF0und, Ano 3, Vol. 1, n²8 - maio/2003, ISSN 1676-2916.

URL: 〈http://www.facom.ufba.br/ciberpesquisa/404nOtF0und/404_28.htm>

Avaliando a EAD. Disponível em: EAD, Unicamp, Revista Digital, mar. 2003.

URL: 〈http://www.rau-tu.unicamp.br/nou-rau/ead/document/?code=22>

ROMISZOWSKI, A. A Methodology for Case-Study in Virtual Groups. [19--]. Disponível em: < http://www.economia.ufpr.br/ead/textos/metodologia/methodology.doc $>$. Acesso em: 10 dez. 2002.

ROMISZOWSKI, H. P. Competencies for Online Teaching. Resenha sobre o artigo publicado por SPECTOR, M e LA TEJA, I. Competencies For Online Teaching. In: Eric Digest, ERIC Clearinghouse on Information \& Technology at Syracuse University, 2001 (http://www.ericit.org/). V. 1, n.1, ABED, julho, 2002. Disponível em: $<$ http://www.abed.org.br/publique/cgi/cgilua.exe/sys/start.htm?sid=46\&UserActiveTemplat e=2ing\&infoid=27>. Acesso em: 20 jun. 2003. 
SABA, F. Is distance education comparable to 'traditional education'?. 1999.

Disponível em: 〈http://www.distance-educator.com/der/comparable.html〉. Acesso em: 10 dez. 2001.

SANTORO, F. M.; DA SILVA BORGES, M.R. \& SANTOS, N. Framework para Estudo de Ambientes de Suporte à Aprendizagem Cooperativa. [19--]. Disponível em: 〈http://www.inf.ufsc.br/sbc-ie/revista/nr4/Sbie98-03-Santoro.htm>. Acesso em: 05 abr. 2002.

SANTOS, F. B.; MACHADO, M. A. S. \& CAMPOS, P. G. Ciberespaço: Conhecimento e Aprendizagem Colaborativa. [19--]. Disponível desde nov.2000 em:

<http://mlarucci.tripod.com/trabalhos/ciberespa.htm>. Acesso em: 29 jul. 2002.

SCHLEMMER, E. Projetos de Aprendizagem baseados em Problemas: Uma metodologia interacionista/construtivista para formação de comunidades em Ambientes Virtuais de Aprendizagem Colabora - Revista Digital da CVA-RICESU, v.1, n. 2, nov. 2001. 10 ps.

SMALLEN, D. \& LEACH, K. Making a NICER Transition to the Millennium: Five Keys to Successful Collaboration. Educom Review, v.34 n.4, 1999. Disponível em: 〈http://www.educause.edu/ir/library/html/erm9945.html >. Acesso em: 20 de jan. 2001.

SNYDER, I. Special Issue of Pedagogisch Tijdschrift. 2002. Artigo enviado para <vcqm@uol.com.br> em 09 set. 2004.

SPADA, N. Lingüística Aplicada ao Ensino de Língua Estrangeira. [entrevista].

ReVEL. Ano 2, n. 2, mar. 2004. ISSN 16788931.

Disponível em:

$\langle$ http://planeta.terra.com.br/educacao/revel/edicoes/num_2/entrevista_12.htm〉. Acesso em: 20 maio 2004.

SPECTOR, J. M. \& La TEJA. Competencies for Online Teaching. Eric Digest. Dec. 2001. Disponível em: 〈http://www.ibstpi.org/online-competencies.pdf〉. Acesso em: 25 abr. 2003.

STICHT, T. G. The Theory Behind Content-Based Instruction. Focus on Basis. v.1, issue D, Dec. 1997. Disponível em: 〈http://gseweb.harvard.edu/ ncsall/fob/1997/sticht.htm〉. Acesso em 20 maio, 2004.

SULER, J. Making Virtual Communities Work. Jan. 1996, revised Oct. 1998 (v1.0). Disponível em: 〈http://www.rider.edu/ suler/psycyber/commwork.html〉. Acesso em: 20 out. 2003. 
TELES, L. et al. Investigating the role of the instructor in online collaborative environments. TeleLearning NCE. Project 5.25., Simon Fraser University, Vancouver, April 2000. Disponível em:

〈http://www.telelearn.ca/g_access/news/investigating_role.pdf〉 $>$. Acesso em: 13 ago. 2001.

THE COMMONWEALTH OF LEARNING. An introduction to Open and Distance Learning. 2000. Disponível em: 〈http://www.col.org/ODLIntro/introODL.htm〉. Acesso em: 22 ago. 2001.

THORNBURG, D. D. 2020 Visões para o Futuro da Educação. 1997. Disponível em: <http://www.tcpd.org/thornburg/handouts/2020visionsport.html>. Acesso em: 12 ago. 2002.

VETROMILLE-CASTRO, R. A usabilidade e a elaboração de materiais para o ensino de inglês mediado por computador. In: X CONGRESSO INTERNACIONAL DE EDUCAÇÃO A DISTÂNCIA, 2003, Porto Alegre. Texto da Biblioteca Online da ABED... Porto Alegre: ABED, 2003. Disponível em: Disponível em: $\langle$ http://eventos.ead.pucrs.br/x_congresso_abed/docs/anais/TC56.htm〉. Acesso em: 13 out. 2003.

VON STAA, B. Elaboração e avaliação de design de curso instrumental on-line de escrita acadêmica em inglês. 2003. 262 p. Tese de Doutorado em Lingüística Aplicada. Pontifícia Universidade Católica - São Paulo. Disponível em:

〈http://lael.pucsp.br/lael/teses/tese_betina.zip〉. Acesso em: 27 maio 2004.

WAGNER, P. R. et al. Ferramenta Gerenciadora de Ambientes de Aprendizagem em EAD. In: X CONGRESSO INTERNACIONAL DE EDUCAÇÃO A DISTÂNCIA, 2003, Porto Alegre. Texto da Biblioteca Online da ABED... Porto Alegre: ABED, 2003. Disponível em: <http://eventos.ead.pucrs.br/x_congresso_abed/docs/anais/TC90.htm>. Acesso em: 13 out. 2003.

WARSCHAUER, M. Motivational Aspects of Using Computers for Writing and Communication, 1996. Disponível em: <http://www.lll.hawaii.edu/nflrc/NetWorks/NW1/NW01.html>. Acesso em: 20 mar. 1999.

WINOGRAD, D. Guidelines for Moderating Online Educational Computer Conferences, 2000. Disponível em: 〈http://www.emoderators.com/moderators/winograd.html〉. Acesso em: 28 mar. 2004. 
A pêndices 


\title{
A pêndiø $A$
}

\author{
Q uestionário Inicial
}

Este, primeiro exemplo de questionário, por mim elaborado, teve por objetivo tentar traçar um breve perfil dos alunos interessados em participar do curso $B G W$.

Subject: FORM results

Reply-to: No.Return.Email@geocities.com (Geocities WebMonitor mail)

From: No.Return.Email@geocities.com (Geocities WebMonitor mail)

To: <email do professor>

Sent from Mail Form posted at:

http://www.geocities.com/Athens/Olympus/4038/newst.html

(name)

(email)

(country)

(background)

(comments - general expectations about the course)

(skills)

(text editor)

(browser)

(other applications)

(how did you learn about the EFI courses?)

Remote IP: 


\title{
A pêndice $B$
}

\author{
E menta do Curso BG W
}

\section{Course Information}

Course name: BGW (Beginner Grammar Writing) Instructor: Vera Mello

\section{Objectives of the course}

This 2-month course has as its main objectives:

- To guide students to write short paragraphs in a completely amusing way;

- To help students to develop linguistic and communicational abilities through tasks, chat, and discussion forums;

- To promote interaction, participation and cooperative learning among students and teacher;

- To develop autonomy, collaboration, social integration, mutual respect, awareness and understanding of cultural diversities;

- To help students to work towards their own learning taking into account their pace and learning styles;

- To contribute to individual and group learning development.

At the conclusion of the course, participants should be able to write a short paragraph effectively.

\section{Course Requirements}

In order to successfully complete the course participants are expected to:

- have some computer literacy;

- $\quad \log$ on to the course site at least twice a week;

- be active participant in the course;

- check suggested extra reinforcement materials;

- do all the tasks assigned as group or individual work weekly;

- participate in the forum discussion either by posting a reply to a message, or by creating a new topic for discussion;

- participate in previously scheduled chat sessions;

- read all the messages posted by the instructor and mates.

- $\quad$ send a note to the tutor if facing personal problems and do not want to be removed from the course.

NO COMMUNICATION IN A 2-WEEK PERIOD IMPLIES AUTOMATIC REMOVAL FROM THE BGW GROUP.

\section{Method of Instruction}

No books will be required.

New assignments will be posted in the form of weekly lessons for participants to read and work on. Comments and explanations will be sent via email to individuals and/or to the group. 
Grading

- $\quad$ No special test will be given.

- Students will be asked to self evaluate their performance throughout the course as a way of being aware of their own learning process and will also receive the tutors' feedback on their progress once a month.

Before starting the course, it's mandatory that you fill the new students' form and that you accept all the requirements for taking the course.

A certificate may be given by EFI upon request and after the learner passes a BGW course test which consists of writing a short paragraph. 


\section{A pêndice C \\ C onteúdo e organização do curso}

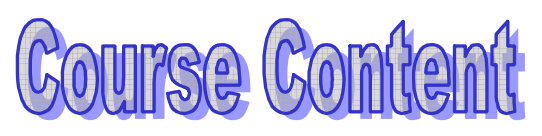

Module I (about 2 months)

The course will cover the following Grammar topics:

- Subject and Verb Agreement

- Punctuation

- Definition of Sentence.

- Elements of a Simple Sentence

- Coordinating Conjunctions \& Transitions

- Combining Sentences using Coordinating Conjunctions \&/or Transitions

- Inserting Adjectives in a Sentence

- Inserting Adverbs in a Sentence

- Subordinating Conjunctions

- Complex Sentences

- Combining Sentences using Subordinating Conjunctions

- Compound-Complex Sentences

- Verb Tenses

- Adjectives and Adverbs

- Adjective Order

- Adverb Order

- Prepositions 


\section{Readings:}

- Short adventurous story (tale)

- What is a community?

- How to prepare a tasty piece of writing.

- Successful on-line learner

- What is your learning style?

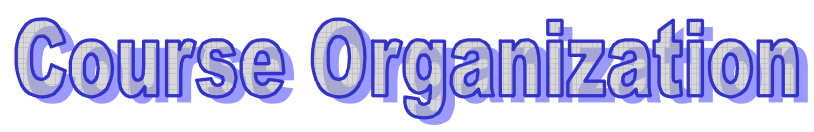

The course will basically be composed of reading and writing activities. The readings will help the students to expand vocabulary; to introduce students to collaborative work (tasks) and to group dynamics; to reinforce pre-studied grammar topics, and to serve as a link to developing writing skills. They will also supply topics for discussion to be posted in the group discussion board. Selected written exercises will expose students to brief grammar explanations, as well. The exercises will range from more to less structured ones, and resources for further studies on the covered grammar topics will be provided to the students. 


\section{A pêndioe $\mathrm{D}$}

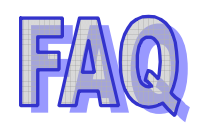

(construída a partir das dúvidas mais freqüentes dos alunos, refletindo o momento em que o grupo se encontrava).

1. How do I log in?

Log in using the username \& password given by the tutors. You will automatically be sent to a new page. Click on the Beginner Grammar Course link and you will be redirected to the course main page. When the page loads, you'll see the navigation bar on your left with the course links. Take a tour around and have fun!

2. I can't login using the username \& password the tutors gave me.

Make sure you use only small letters. If you have problems, contact us immediately.

3. Who should I contact if I have any technical problems?

Contact the tutors immediately describing the problems you are facing.

4. Where do I find the materials for the course?

The course is set at Blackboard. All the tasks, materials \& links are found there.

5. Should I always check the Announcements?

Yes. There you'll find the important info about the course. Make sure you also check the weekly announcements.

6. Is everyone required to edit a homepage at Blackboard?

Yes, all the students should edit their own homepage with personal info, a photo and whatever info they find relevant and interesting to share with their mates.

7. Where should I edit my homepage?

It is pretty easy. You don't need to be an expert to do it. Just click on Student Tools (see main navigation buttons on your left) and then on Edit Homepage. Finally let your imagination flows.

8. And if I want to check my cyber mates' homepages?

To check your mates' pages, click on Communication then Roster. When the new page loads, click on List All and then again on List All, and finally on the person's name. If you want to send the person email, just click on his/her email address.

9. Is there a task checklist that helps me find out what I have to do weekly?

Yes, you can find it in Students Tools. Scroll the bar down to Tasks. 
10. Should I send the tutors my assignments?

Only the required ones. Some assignments are for you to check yourself comparing your answers to the answer key that will be posted to the site a week after the assignment is proposed/due.

11. And if I have any grammar/vocabulary doubts?

If you have any grammar/vocabulary doubts, post your question to the group first so that any cyber mate can try to help you. Remember that collaboration is the name of our game!!! However, if nobody can answer the question, use the external link Help in Discussion Board to contact the tutors.

12. Where should I post doubts to the group?

Use the thread Sharing Doubts in the main Discussion Board.

\section{Should I often check the Discussion Board?}

Yes, there should always be new posts there. It's mandatory that you read your mates' posts and reply to them.

14. Can I add a new thread?

Sure. At any time you can do it.

15. When are new assignments posted at Blackboard?

New assignments are posted at Blackboard once a week, and the students have one week to work on them.

16. And if I have a problem and can't do the assignments?

Please let the tutors know if you have any problems so that you won't be removed from the course.

17. When are students removed from BGW course?

If we don't hear from you within two weeks, you will automatically be removed from the group.

18. Why am I required to do collaborative work?

Because you should not depend only on the tutors. We are always learning from each other, and our success is greater when we share insights, doubts and ideas with our mates and tutors. Learning becomes enriched by everyone's contribution.

19. Will there be any individual work?

Sure. There will be some and you will know exactly when you should work on your own.

20. When I work with a mate, where should I post the assignment?

Post the assignment in the Virtual Writing Room in the main Discussion Board.

21. When should I use the students' private Discussion Board? 
Use that area if you want to discuss private topics with your mate or to post corrections/ new items pointed out or suggested by the tutors after reading your assignments which were posted in the Virtual Writing Room.

22. When will we have chat sessions?

Tutors will try to run monthly chat sessions.

23. And if I cannot attend the chat session?

If you can't attend the chat session pre-scheduled by the tutors, contact us immediately justifying your absence.

24. Will I be able to know what was discussed in the chat session?

Yes. Logs of the conversations are automatically saved for your perusal. Just click on Virtual Classroom and then Chat archives.

25. Can the students use the chat even if the tutors are not online?

Sure. You may use the chat to have private conversation with other members of the group.

26. What are the main course requirements?

It's always good to reinforce the requirements. Remember that you are expected:

to do all the assignments.

to work \& collaborate with your mates

to be eager to participate in all activities proposed.

to give us constant feedback so that we can create a course based on your needs.

27. Where do I find info about the course modules, organization and content.

Please read the Content doc found in the Course Documents.

28. If I don't find an answer to a question in the FAQ, can I write the tutors?

Sure, feel free to contact the tutors whenever you have a problem. 


\section{A pêndioe $E$}

\section{Q uestionário sobre 0 Primeiro M omento do C urso}

Date: Sat, 4 Aug 2001 13:02:41 -0400

To:

From: vcqm@ ruralsp.com.br

$\mathrm{CC}$ :

Subject: Important News

Dear students,

Here are some important notes from the course. V. and O. have been active in the group and working pretty well together.

Vanessa is pregnant and probably busy with her new home, and Soco, as far as I know, is moving back home. No news from Ursula for a time.

Well, this brief message is to ask you some questions. Please answer them accordingly and as soon as possible so that we can move on.

1. Do you plan to continue your studies with BGW?

2. As a student who has been in the online course for sometime, would you be willing to help your tutors with the new comers? How?

3. What have you learned in the course? Have the writing and reading tasks been helpful? In what ways?

4. Have you become a better online learner? Have you learned things that you could apply to your personal/professional life? What?

5 . What would you suggest to improve the course?

6 . Has the collaborative work been effective to you?

Why? Why not?

Best,

Vera (EFI teacher) 


\title{
A pêndice $F$
}

\author{
A tividades Colaborativas
}

O material aqui apresentado compõe o rol de atividades colaborativas propostas no primeiro momento do curso $B G W$.

\section{Chat session}

*2. A nice tale. Would you like to discover what it is about? (*it did not work)

If you are curious please ask a question just to let you bring to light what the story is about. :-)))

WAITING FOR YOUR QUESTIONS!!! IT IS AN INTERESTING STORY !!!

\section{Chat session}

4. Short paragraph writing - interview a mate. Send a copy of your questions and your mate's answers to us.

\section{Error Correction II.}

Here you will find some common errors that should be avoided. If you go back to the explanations of sentence structure and verb tense (present), you will be able to find what the error is/ errors are.

Pair with a mate and check if you both agree about the corrections. As always, don't forget to send me a copy of your assignment. 


\section{A pêndiø $G$}

A tividades individuais/ olaborativas

O material aqui apresentado compõe o rol de atividades individuais/colaborativas propostas no primeiro momento do curso $B G W$.

1. Verb tenses - (Explanations not included in this Apêndice)

Part I: Now that you got some information about the form and usage of the present tense, let's see if you can answer a few questions....

*Part II: Reinforcement exercise.

Write a short paragraph (4 to 5 sentences) telling about your daily routine.

Steps to be followed to do the writing exercises:

a. Do the activities based on verb tenses $(1 \& 2)$ and the short paragraph writing.

b. Send your answers and paragraph to a mate.

c. Each student has to read the answers and the paragraph written by the colleague and is supposed to check whether the verb tense was used correctly in the sentences.

d. Send me a copy of the activity.

e. If nobody contacts you, please let me know immediately.

2. Verb tenses (simple present)

I- Complete the sentences in a meaningful way.

Sentences....

II- Write a short paragraph about your country.

Send the paragraph to all your mates and a copy to me. Each student should receive four paragraphs. Read them all and choose the one you liked the best. Then send a short note of congratulations to that person (and a copy to me and to the other students) telling why you choose that paragraph.

And the winner is..... !!!! ;-)

3. Sentence re-arrange II - do the exercise individually and then compare your answers with a mate. Finally check the answer key.

4. Punctuation I. (Explanations not included in this Apêndice). Check your answers with a mate and post doubts in the forum. Answer Key provided. 


\section{Simple Past.}

Here is a review of past tense before we go to the present perfect which is the most confusing form in English. You all know that normal verbs take -ed for the past. The past in English is used to describe actions which happened in the past and are finished or actions that happened regularly in the past. (Explanations/Examples/List of Irregular Verbs - were not included in this Apêndice).

I. To practice the past send a copy to all your mates telling them: what you did last night:

what you did last week:

something you did last month:

something you did last year:

what you did two weeks ago:

II. This is the story of Cinderella, a fairy tale. Complete the story using a verb in the past tense. Be careful to make your story meaningful.

Cinderella a young woman who with her stepmother and her two ugly

sisters. Cinderella while her two sisters to do all the work around the house. She beautiful clothes. One day there and palace and a beautiful fairy godmother the ball - but she to be back by midnight. So Cinderella Cinderella that she could go to with the handsome prince. As she she dropped her glass slipper on the stairs. The next day the prince searched everywhere for Cinderella and when he her he married her.

Now, read the story again below and correct the mistakes, using a past simple negative, like this: No, Cinderella wasn't a man, she was a woman. OK?!

Have fun!!

Cinderella was a young man who lived with her stepmother and her two beautiful sisters. Cinderella made the two sisters do all the work around the house and she wore beautiful clothes while her two sisters went around in rags. One day there was a ball at the palace and an ugly fairy godmother appeared and told Cinderella that she could go to the ball - but she had to be back by half-past seven. So Cinderella went to the ball and danced with the short fat prince. As she left she dropped her football boot on the stairs. The next day the prince searched everywhere for Cinderella and when he found her he gave her a job in the palace kitchen.

III - Create a story. DO NOT ANSWER THE QUESTIONS. Use the questions to develop the plot of your story.

Yesterday Bob and his little brother Bill ....

a) What were they doing?

a) What happened to them?

b) What did they do?

c) How did they feel?

d) Who did they tell about it?

e) What happened next? 
6. Punctuation II (Explanations not included in this Apêndice). Check your answers with a mate and post doubts in the forum. Answer Key provided.

7. Punctuation (re-inforcement exercise). Check doubts with a mate and then send me a copy.

*8. Short adventurous story (tale - new proposal)

Note: I guess the short story task is not working. I will place the whole story to all just in case some of them want to read it. Do you agree? I will also ask the ones who are interested, to join in twos or threes and send us a paragraph with the comments of the story.

*9. Reinforcement exercise (to be exchanged with a mate)

To make sure you internalized the rules we have been discussing (sentences, complements $\&$ word order) and that you can apply them to new contexts, prepare a 4-sentence exercise (of any kind: true/false, fill-in, multiple choice, etc) and email it to your partner.

Important note: When you get the exercise your partner created for you, do it and then send me a copy of the entire exercise for comments.

10. Conjunctions and transitions and exercises. (Explanations not included in this Apêndice). Do individually and then check the answers with a mate. Answer Key provided.

11. What is a community? (Reading)

Pre-reading/Reading/Post-reading activities: Email your answers to a mate. Everyone should have his/her own answers to the reading activities and the answers sent by a mate. Compare your answers to the ones given by your mate and check whether they are the same or not. Always send me a copy of what you and your mate are doing.

12. How to prepare a tasty piece of writing (Reading)

Pre-reading/ Reading/ post reading: Give your opinion.

Note: You may find it interesting to discuss the reading activity II \& the post-reading activities with your mates. Post your answers in the Forum.

Refer back to the tutors if you have any problems.

13. Combining sentences. Individual and then compare answers with a mate.

14. Error Correction I. Individual and then compare answers with a mate.

15. Combining sentences with subordinating conjunctions. Individual and then compare answers with a mate.

16. James Bond (adjective/ adverb - fill in) Individual and then compare answers with a mate.

17. Verbs (present continuous)

(Explanations not included in this Apêndice).

Now that you got some information about the form and usage of the present continuous, let's do some exercises. 
I. People often find their first experience abroad exciting and frightening. Imagine you just arrived in a foreign country. Write five sentences describing your reactions by using the following cues.

1. I/ feel

2. The people/seem

II. You have to interview a person. What kind of questions would you like to ask her/him? Use your imagination. Discuss your questions with a mate and send me a copy of your work.

III. For further practice using present and present continuous, do the following exercise: http://www.geocities.com/suzkeadie/vpressimvprescont.html

*18. Short paragraph writing - invitation card. Send the card to two mates and see if they reply to your invitation. This is a short writing activity to test your creativity and master of the present tense.

Follow the steps:

a) Send a card to everyone in the group inviting the person to visit your country.

b) Mention the best time for a visit to your country (in the summer, winter, fall or spring) and why the person should go.

c) Make sure you write a nice invitation card.

You can either create your own card, or use one from any online greeting cards site.

Next class I'll send you the second part of this task. Enjoy the activity!!!!

19. Successful Online Learner - take the quiz and post your answer - discussion board. (Reading)

Pre-reading/reading/post-reading activities: a. Are you an on-line student? Why do you say so?

b. What two characteristics mentioned in the reading would you consider the most important ones? Why?

P.S. As always team up and discuss your answers before sending them to me.

*20. Birthday Celebration (Extra Writing Activity)

Is your birthday in June? Find out how many of your cybermates are celebrating their birthday in June.

Go to http://www.geocities.com/Athens/Olympus/4038/photos.html and find it out.

Now, what about having a Virtual Birthday Party? Do you like the idea?

So let's do the following:

1. if you are celebrating your birthday this month, get together with the mate(s) and try to plan a cyber party. You may find it interesting to send the other mates a virtual map of the place where the party will take place, the invitation card, the list of food and drinks that will be served (maybe something typical of your country), and.... whatever you feel like. Let your imagination guide you.

2. if you are only a virtual guest, get together and try to create a nice and fun birthday card and a virtual gift. 
21. Welcome Party project.

As of July $15^{\text {th }}$, new students will be joining our group. What about working on a welcome party for them? How about making them feel part of the group from the very beginning?

Discuss possible ways of having a virtual welcome party for the newcomers.

Be creative! Use your imagination!

Each one can be assigned a task that you yourselves propose, and then you can all together come up with a final product. Let's see what you can do by yourselves.

You have 15 days to work on the project and report back to me. I think that's plenty of time, right?

22. New tool: Wimba (activity done only by Vera N. from Russia)

* There's a new addition to our course: a new voice message board. Check my homepage.

You can hear and reply to my voice message. I hope you like it ;-) Comments for improvement in any area of our course are welcome. 


\title{
A pêndic $H$
}

\author{
A tividades individuais
}

O material aqui apresentado compõe o rol de atividades propostas no primeiro momento do curso $B G W$ para serem realizadas individualmente.

\section{Individual assignments:}

1. Edit your own homepage.

Please visit your cybermates' pages.... many included their favorite links and their picture. Real cool!!! Those who have not created their home pages yet, please do so. Remember this is a virtual community, and we all want to 'know' our students and mates.

2. Sentence Rewriting (based on the common errors gathered in the students' first paragraph writing). Answer Key with comments.

3. What is a Sentence and exercises. Explanation provided. Answer Key available.

4. Sentence Rearranging. Answer Key available.

5. Simple Present and Present Continuous (Reinforcement Exercises).

Ask appropriate questions for the answers given:

Example:

My name is Vera.

The question should be What is your name?

6. Simple Sentences and exercises. Explanation provided. Answer Key available.

7. Questions and answers - Game-like activity: a way for the students to know each other and to read what their mates' interests are. (Answers based on the homepages and on the chat session).

8. Review quiz (based on what students have learned during the course)

Name: Keep tuned!

Type: multiple choice. 
9. Subject and verb agreement exercise. Explanation provided. Answer Key available.

10. Mixed verbs (reinforcement exercises).

11. What is your learning style?

As a reading assignment, I suggest that you visit Catherine Jester's page and take the 32 multiple choice survey quiz. By submitting your answers, you will automatically find out what your learning style is.

Go to http://www.metamath.com//multiple/multiple_choice_questions.cgi

Then take notes of any new word and check the meaning in the dictionary.

Finally answer the following question: What is your learning style? How much does knowing your learning style help you in your studies? Post your answer in the Discussion Forum - Writing Room.

12. Puzzle -- Classroom Objects.

13. Puzzle II (curiosity/motivation)

Mr Brond has as many cows on his farm as Mr. Wood has, they have the same number. Mr. Wood has three cows more than Mrs Forest has on his. Mr. Grave hasn't as many cows as Mr. Forest. Which of the four farmers has the fewest cows?

14. Questionnaire II. (See Apêndice E)

In the Discussion Forum:

15. English is easy to learn. (First paragraph writing).

16. Technical Problems.

17. What does success mean to you?

18. My first experience at Blackboard

19. Learning Online

20. Grammar Trouble shooting

21. How I relate with others

22. English Grammar

23. Chat (observations)

24. Proverb

25. First students' feedback

26. Learn who you are working with 
27. Find out what your mates' impression of the chat session was.

\section{Query}

29. Puzzle (masculine from feminine)

Grammar: In English we form the feminine from the masculine. E.g.:

$$
\begin{aligned}
& \text { poet....poetess } \\
& \text { god......godess } \\
& \text { actor....actress }
\end{aligned}
$$

There are only two cases in which the masculine seems to be formed from the feminine. Do you know which these two nouns are? Come on!!! Revise nouns...go over the list of masculines and feminines!!! :-)) 


\title{
A pêndice I
}

\section{Q uadros de Programação M ensal de A tividades do C urso BG W}

\author{
Task (Checklist)
}

January

\begin{tabular}{|c|c|c|}
\hline Task & Date & Topic \\
\hline 1 & $01 / 06 / 01$ & $\begin{array}{l}\text { Meet your Classmates and improve your English } \\
\text { - Edit Homepage. Include relevant info \& your picture. (Click on Tools) } \\
\text { - First Paragraph Writing. (Use the Discussion Board - thread: *English is easy to learn* to } \\
\text { write your paragraph). }\end{array}$ \\
\hline 2 & $01 / 13 / 01$ & $\begin{array}{l}\text { Improve your English } \\
\text { - Short exercise: Sentence Rewriting I (based on students' first paragraph writing common } \\
\text { problems). (Assignments - Developing Writing Skills) } \\
\text { Links to grammar drills (check: External Links). }\end{array}$ \\
\hline 3 & $01 / 20 / 01$ & $\begin{array}{l}\text { Improve your English } \\
\text { - What is a Sentence? And related exercises. (Assignments - Developing Writing Skills) } \\
\text { - More links to drills (External Links) }\end{array}$ \\
\hline 4 & $01 / 27 / 01$ & \begin{tabular}{|l} 
Improve your English \\
- James Bond (fill-in-the-blanks). (Assignments - Developing Writing Skills) \\
Answer Key with reminders - - What is a Sentence? (part 1) (Assignments - Developing \\
Writing Skills.) \\
- Technical Problems (Discussion Board)
\end{tabular} \\
\hline
\end{tabular}

Quadro 1 - Programação de atividades (Janeiro de 2001) 
Task (Checklist)

February

\begin{tabular}{|c|c|c|}
\hline Task & Date & Topic \\
\hline 1 & 02/03/01 & \begin{tabular}{|l} 
Improve your English. \\
$\begin{array}{ll}\text { - } & \text { Sentence Rearranging. (Assignments) } \\
\text { - } & \text { What does success mean to you? (Discussion Board) } \\
\text { - } & \text { My first experience at Blackboard (Discussion Board) } \\
\text { - } & \text { Learning Online (Discussion Board) }\end{array}$
\end{tabular} \\
\hline 2 & $02 / 10 / 01$ & $\begin{array}{l}\text { Improve your English } \\
\begin{array}{ll}\text { - } & \text { Sentence Rearranging (Answer Key - Assignments) } \\
\text { - } & \text { Mixed tenses (Assignments). } \\
\text { - Simple Sentences and exercises (Assignments) } \\
\text { - External Links: Controlling ideas; linking words \& presidential facts } \\
\text { (complementary exercises) }\end{array}\end{array}$ \\
\hline 3 & $02 / 17 / 01$ & \begin{tabular}{|ll} 
Improve your English \\
- & Answer key - Mixed tenses (Assignments) \\
- & Answer key - Simple Sentences (Assignments) \\
- & Grammar Troubleshooting (Discussion Board) \\
- & How I relate with others (Discussion Board) \\
- & English Grammar (Discussion Board)
\end{tabular} \\
\hline 4 & $02 / 24 / 01$ & \begin{tabular}{|l} 
Improve your English \\
- \\
- $\quad$ Punctuation I (Assignments) \\
- $\quad$ Chat - leave a note if you have problems participating in the session. \\
- Discussion Board) \\
- $\quad$ Proverb (Discussion Board) \\
- Extra exercises: conjunctions 01 \& conjunctions 02
\end{tabular} \\
\hline
\end{tabular}

Quadro 2 - Programação de atividades (Fevereiro de 2001) 
Task (Checklist)

March

\begin{tabular}{|c|c|c|}
\hline Task & Date & Topic \\
\hline 1 & $03 / 03 / 01$ & \begin{tabular}{|l} 
Improve your English. \\
$\begin{array}{ll}\text { - } & \text { Chat activity (7:00 pm GMT). Check link to world clock - } \\
\text { (Announcement) } \\
\text { - } & \text { First students' feedback (Discussion Board) } \\
\text { - } & \text { Punctuation II (Assignments) } \\
\text { - } & \text { Answer Key - Punctuation I (Assignments) }\end{array}$
\end{tabular} \\
\hline 2 & 03/10/01 & $\begin{array}{l}\text { Improve your English } \\
\text { - Student's feedback. (If you haven't done it yet, please do so. Your } \\
\text { answers are of great value to us). } \\
\text { - Add new or additional info to your homepage. } \\
\text { - Answer Key - Punctuation II (Assignments) } \\
\text { - } \quad \text { Rearrange the phrases II (extra exercise on Norma's site) }\end{array}$ \\
\hline 3 & 03/17/01 & \begin{tabular}{|l} 
Improve your English \\
- \\
- $\quad$ Functuation (reinforcement exercise) (Assignments) \\
(Discussion Board - thread: *Chat) \\
- Invitation to a new chat session (7:00 pm GMT on 03/24).
\end{tabular} \\
\hline 4 & $03 / 24 / 01$ & \begin{tabular}{|ll} 
Improve your English \\
- & Chat session \\
- & Sentence Rewriting (Assignments) \\
- & Chat Feedback (Discussion Board) \\
& Learn who you are working with!!! (Homepage contest)
\end{tabular} \\
\hline 5 & 03/31/01 & \begin{tabular}{|l} 
Improve your English \\
- Chat Log - (check: Virtual Classroom Archives if you were \\
unable to come) \\
- Result of the contest (See Announcements) \\
Tale - ask a question and read Norma's answers to find out what it \\
is about. (Post questions in the Discussion Board).
\end{tabular} \\
\hline
\end{tabular}

Quadro 3 - Programação de atividades (Março de 2001) 
Task (Checklist)

April

\begin{tabular}{|c|c|c|}
\hline Task & Date & Topic \\
\hline 1 & $04 / 07 / 01$ & $\begin{array}{l}\text { Improve your English. } \\
\text { - Be sure to do the tale activity assigned on 03/31. Ask as many questions as you wish. Norma } \\
\text { will guide you with the answers (Use the Discussion Board). } \\
\text { - Answer Key - Sentence rewriting (Assignments) } \\
\text { - } \quad \text { Query (Discussion Board) } \\
\text { - Puzzle: Masculine from Feminine (Discussion Board) }\end{array}$ \\
\hline 2 & $04 / 14 / 01$ & $\begin{array}{l}\text { Improve your English } \\
\text { - Finish all activities assigned. } \\
\text { How collaborative are you? - join the pieces and read the whole story. Everyone has to } \\
\text { participate in the activity to discover the story. The pieces will be e-mailed you. } \\
\text { - New quizzes (Are you tuned in?/ Miscellaneous -- review). }\end{array}$ \\
\hline 3 & $04 / 21 / 01$ & $\begin{array}{l}\text { Improve your English } \\
\text { - } \text { Reinforcement exercise - to be exchanged with a mate (Assessments) } \\
\text { - Subject and verb agreement exercise (Assessments) } \\
\text { - Short adventurous story (to be done in pairs or trios) (Reading Assignments). Read the story, } \\
\text { discuss it with your mates and then send us a paragraph with the comments on the story. }\end{array}$ \\
\hline 4 & $04 / 28 / 01$ & \begin{tabular}{|l} 
Improve your English \\
- Answer key - Subject and verb agreement exercise (Assignments) \\
- $\quad$ More conjunctions and Transitions with exercises (Assignments)
\end{tabular} \\
\hline
\end{tabular}

Quadro 4 - Programação de atividades (Abril de 2001) 
Task (Checklist)

May

\begin{tabular}{|c|c|c|}
\hline Task & Date & Topic \\
\hline 1 & $05 / 05 / 01$ & $\begin{array}{l}\text { Improve your English. } \\
\text { What is a community? (Reading Assignment - to be done in pairs or trios) -Post your } \\
\text { answers in Virtual Writing Room - subject: Reading Activity I) } \\
\text { Answer key - Conjunctions and transitions (Assessments) }\end{array}$ \\
\hline 2 & $05 / 12 / 01$ & $\begin{array}{l}\text { Improve your English } \\
\text { - How to prepare a tasty piece of writing (Reading Assignment - to be done in pairs or trios) - } \\
\text { Post your answers in Virtual Writing Room - subject: Reading Activity II) } \\
\text { - Combining sentences (Assignments) } \\
\text { - Error Correction I (Assessments) }\end{array}$ \\
\hline 3 & 05/19/01 & 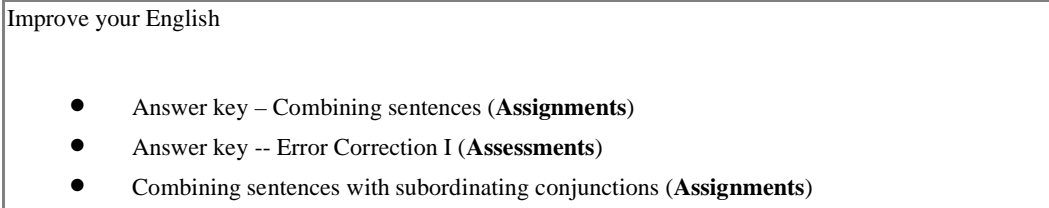 \\
\hline 4 & $05 / 26 / 01$ & $\begin{array}{l}\text { Improve your English } \\
\begin{array}{l}\text { - Finish the activities assigned last week and send the answers to me or to Norma. } \\
\text { - Error Correction II (Assessments) }\end{array}\end{array}$ \\
\hline
\end{tabular}

Quadro 5 - Programação de atividades (Maio de 2001) 
Task (Checklist)

June

\begin{tabular}{|c|c|c|}
\hline Task & Date & Topic \\
\hline 1 & $06 / 02 / 01$ & $\begin{array}{l}\text { Improve your English. } \\
\begin{array}{ll}\text { - } & \\
\text { - } & \text { Answer key -Error Correction II (Assessments) } \\
\text { - } & \text { Extra writing activity: Birthday Celebration - (Assignments) }\end{array}\end{array}$ \\
\hline 2 & $06 / 09 / 01$ & $\begin{array}{l}\text { Improve your English } \\
\begin{array}{l}\text { Short paragraph writing - interview a mate). Send a copy of your questions and your mate's } \\
\text { answers to us. (Assignments) }\end{array} \\
\text { Verb tenses II (reinforcement exercises - Assignments) }\end{array}$ \\
\hline 3 & $06 / 16 / 01$ & $\begin{array}{l}\text { Improve your English } \\
\text { - Short paragraph writing - invitation card. Use your imagination and creativity!!! Send the carc } \\
\text { to two mates and see if they reply to your invitation. (Assignments) } \\
\text { - Verb tenses III (reinforcement exercises - Assignments) }\end{array}$ \\
\hline 4 & $06 / 23 / 01$ & $\begin{array}{l}\text { Improve your English } \\
\text { - Successful Online Learner (Reading Activity III - check the link and take the quiz. Post your } \\
\text { answer in the Discussion Board). } \\
\text { Verb tenses IV (reinforcement exercises - Assignments) }\end{array}$ \\
\hline 5 & $06 / 30 / 01$ & $\begin{array}{l}\text { Improve your English } \\
\text { What is your learning style? (Reading Activity IV - check the link and post your answer in the } \\
\text { Discussion Board). } \\
\text { - Try the new tool: Wimba - link on my homepage. }\end{array}$ \\
\hline
\end{tabular}

Quadro 6 - Programação de atividades (Junho de 2001) 
Task (Checklist)

July

\begin{tabular}{|c|c|c|}
\hline Task & Date & Topic \\
\hline 1 & $07 / 07 / 01$ & $\begin{array}{l}\text { Improve your English. } \\
\text { - } \text { Puzzle - Classroom Objects } \\
\text { - Welcome Party Project } \\
\text { - Puzzle II (are you curious about the answer? Check next week.) }\end{array}$ \\
\hline 2 & $07 / 14 / 01$ & \begin{tabular}{|l} 
Improve your English \\
- Finish the Welcome Party Project \\
- Questionnaire II - comments/observations about the BGW course.
\end{tabular} \\
\hline
\end{tabular}

Quadro 7 - Programação de atividades (Julho de 2001) 


\section{A pêndice J}

E x emplo de A tividade de L eitura

\section{Pre-reading activity:}

I. You'll find these words in the text you'll read. If you don't know them, check the meaning in the dictionary. Then, define the words in the space below.

1. eager

2. lack

3. belonging

4. commitment

\section{Reading activity:}

Short text on: What is a community?

The American Heritage Dictionary (3rd Edition) defines community, among other entries for the term, as "a group of people having common interests". So why is it so difficult to build a community? For a community to exist it's necessary to create a sense of caring and belonging among its members who cooperate with each other, and who are eager to share ideas, insights, experiences and interests.

There may be lack of physical contact, of visual and sound aids in the community, but through textual language shared by members, a sense of connectedness, belonging and commitment come through. Is it important for the BGW to establish a community? Undoubtedly the answer is yes, for a community is the key to successful online learning.

I . Answer T (true) or F (false)

1. If there's no physical contact, a community cannot come into existence.

2. A community shares equal interests and its members are committed to one another.

\section{Post-Reading activities:}

What is your opinion about the text?

NOTE: Email your answers to a mate. Everyone should have his/her own answers to the reading activities and the answers sent by a mate. Compare your answers to the ones given by your mate and check whether they are the same or not.

As always send me a copy of what you and your mate are doing. 


\section{A pêndiœ K}

\section{Tecnologia D igital: Plataformas de gerenciamento de aursos na W eb-}

\section{Prometheus e Blackboard}

Com a crescente demanda por cursos on-line, constata-se o aparecimento de um número, cada vez maior, de plataformas de gerenciamento de cursos na Web. Isto tem levado pesquisadores e educadores a analisarem a amigabilidade, adequação, implementação e utilização dessas plataformas para fins educacionais. Dentre as plataformas encontradas, pode-se citar o WebCT, desenvolvido pela University of British Columbia no Canadá; o Prometheus, desenvolvido pela George Washington University nos Estados Unidos, e o Blackboard, desenvolvido pela Blackboard, Inc.

Esses programas gerenciadores de cursos nada mais são do que páginas da Web incrementadas, que agregam ferramentas de administração; de colaboração; de comunicação síncrona e assíncrona; de manutenção, arquivamento e gerenciamento de conteúdos, e gerenciamento de alunos, incluindo dados estatísticos de acesso às diferentes áreas e materiais disponibilizados no sistema, entre outras.

Optei por analisar o Prometheus e o Blackboard, sob o ponto de vista do instrutor (antes de utilizar com os alunos), para verificar a arquitetura, limitações e potencialidades desses dois sistemas de gerenciamento de cursos na Web.

A escolha do Prometheus se deu pelo fato dele ter sido amplamente recomendado, por um membro da lista Neteach-I ${ }^{1}$, como uma plataforma eficaz para montagem de curso na Web. A análise do Prometheus também foi possibilitada por me ter sido concedida uma senha especial para a sua utilização. Por outro lado, o Blackboard foi escolhido porque era um programa do tipo freeware ${ }^{2}$. Desta forma, pôde-se testar o programa, sem preocupação com o período de teste (trial period - que normalmente gira em torno de um mês), ou com custos de programas comerciais semelhantes.

\footnotetext{
${ }^{1}$ Lista da qual faço parte e que reúne professores de inglês interessados em discutir tecnologia como instrumento educacional.

${ }^{2}$ Programa gratuito de livre distribuição e uso. Atualmente o Blackboard é um programa pago e requer licença de uso.
} 
Vale ressaltar também que a experiência que adquiri, como usuária, no manuseio dos recursos oferecidos pelo WebCT ${ }^{3}$, serviram como referencial de análise para o Prometheus e o Blackboard.

\section{1 - Prometheus}

Prometheus é uma plataforma que apresenta uma interface amigável. Um dicionário e um thesaurus (dicionário de sinônimos) integrados ao aplicativo são recursos incomuns a outros programas, mas oferecidos por essa plataforma. Esses recursos são de grande utilidade para professores e alunos de inglês. Selecionando com o mouse, uma palavra desconhecida (encontrada em qualquer área do Prometheus) e clicando em dicionário e/ou em thesaurus, aciona-se o mecanismo de busca e verificação do significado do vocábulo ou sinônimo dele, respectivamente. O programa também oferece tutorial online com informações bastante simples para o usuário comum. Clicando-se em More Info abre-se, sobre a janela original, uma outra embutida como frame ${ }^{4}$, contendo um índice geral de ajuda.

O programa é acessado através do endereço: http://courses.prometheus.com e utilização de um user name (nome do usuário) e senha individual. A tela inicial de um curso disponibiliza informações sobre o mesmo. Como exemplo, a tela do meu curso, onde são mostrados (na parte inferior desta) os seguintes dados: número do curso - \#11.1; nome do curso - BGW Online Course; número de alunos inscritos - três (3), e número de hits 5 .

\footnotetext{
${ }^{3}$ Meu primeiro contato com o programa WebCT se deu no ano de 2000, quando participei, como aluna especial, da disciplina CTR 5001: Novas Tecnologias para uma Nova Educação, ministrada pelo Prof. Dr. José Manuel Moran, na ECA. O WebCT foi utilizado como complemento às aulas presenciais da disciplina.

${ }^{4}$ Característica do html que permite que diferentes arquivos sejam carregados numa mesma janela do Web browser.

${ }^{5}$ Número de acessos a um único arquivo de um servidor Web.
} 


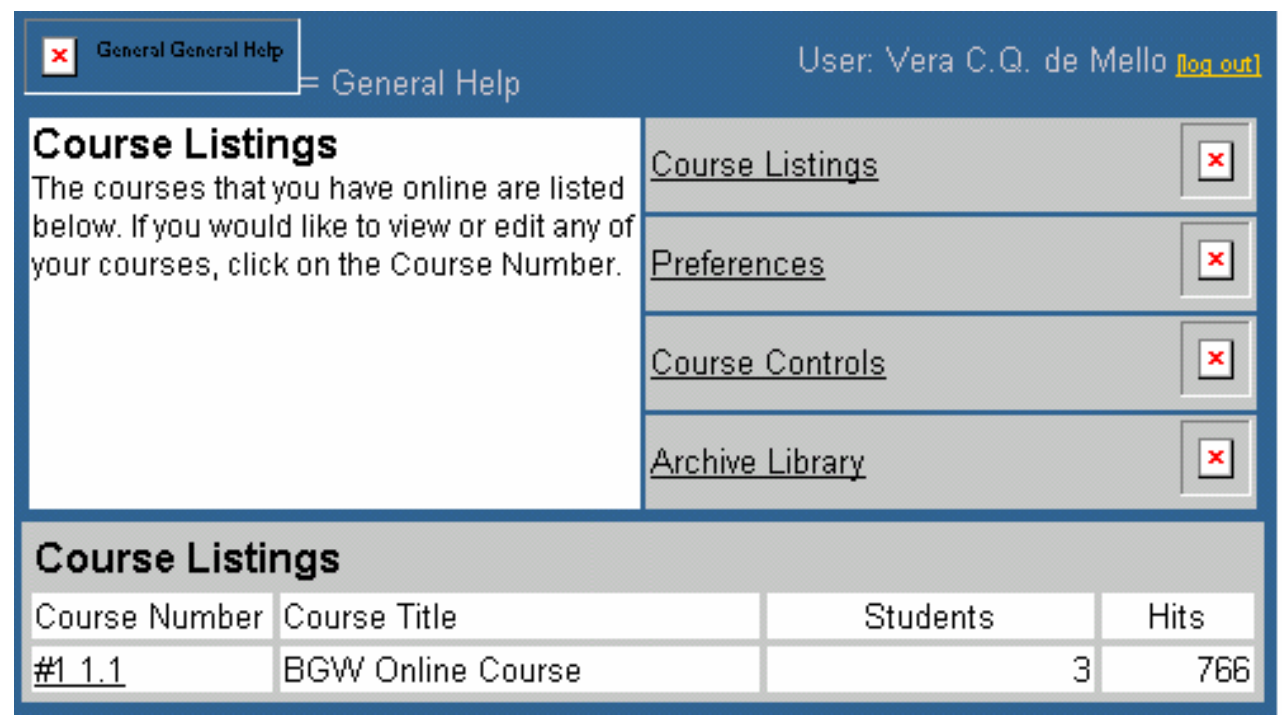

Tela Inicial do Curso

A inscrição é extremamente fácil, pois o próprio programa cria automaticamente uma conta para o aluno. Basta que ele clique em Create a New Account e forneça os seguintes dados: sobrenome, nome, e-mail, user name e uma senha a ser confirmada. Em seguida, o aluno inscreve-se no curso, clicando em Add a Course e fornecendo ao programa o ID (identificação pessoal) e a senha do curso fornecida pelo professor. Restringe-se, desta forma, o acesso somente aos alunos inscritos.

\section{2 - Ferramentas de administração}

Prometheus também oferece ferramentas de administração que propiciam ao professor gerenciar seu curso de forma a atingir os objetivos propostos. Enquadram-se sob esse item: Syllabus e Outline. O primeiro é uma área de planejamento de curso para disponibilização de: informações gerais, descrição do curso, pré-requisitos, objetivo, metodologia e forma de avaliação. Outline, por sua vez, é uma área onde se encontra o sumário das sessões das aulas e as tarefas dadas. Há também a possibilidade de uso de calendário para agendar as atividades do curso. 
A existência dessas áreas é bastante importante, pois possibilita ao professor apresentar aos alunos a estruturação do curso on-line e as dinâmicas elaboradas para a realização do mesmo. Isto tem conseqüências positivas no ensino-aprendizagem, pois, conforme evidenciado por Souza \& Saito (1999), um planejamento sério e cuidadoso do processo pedagógico é fundamental para o sucesso de um curso na modalidade de EAD.

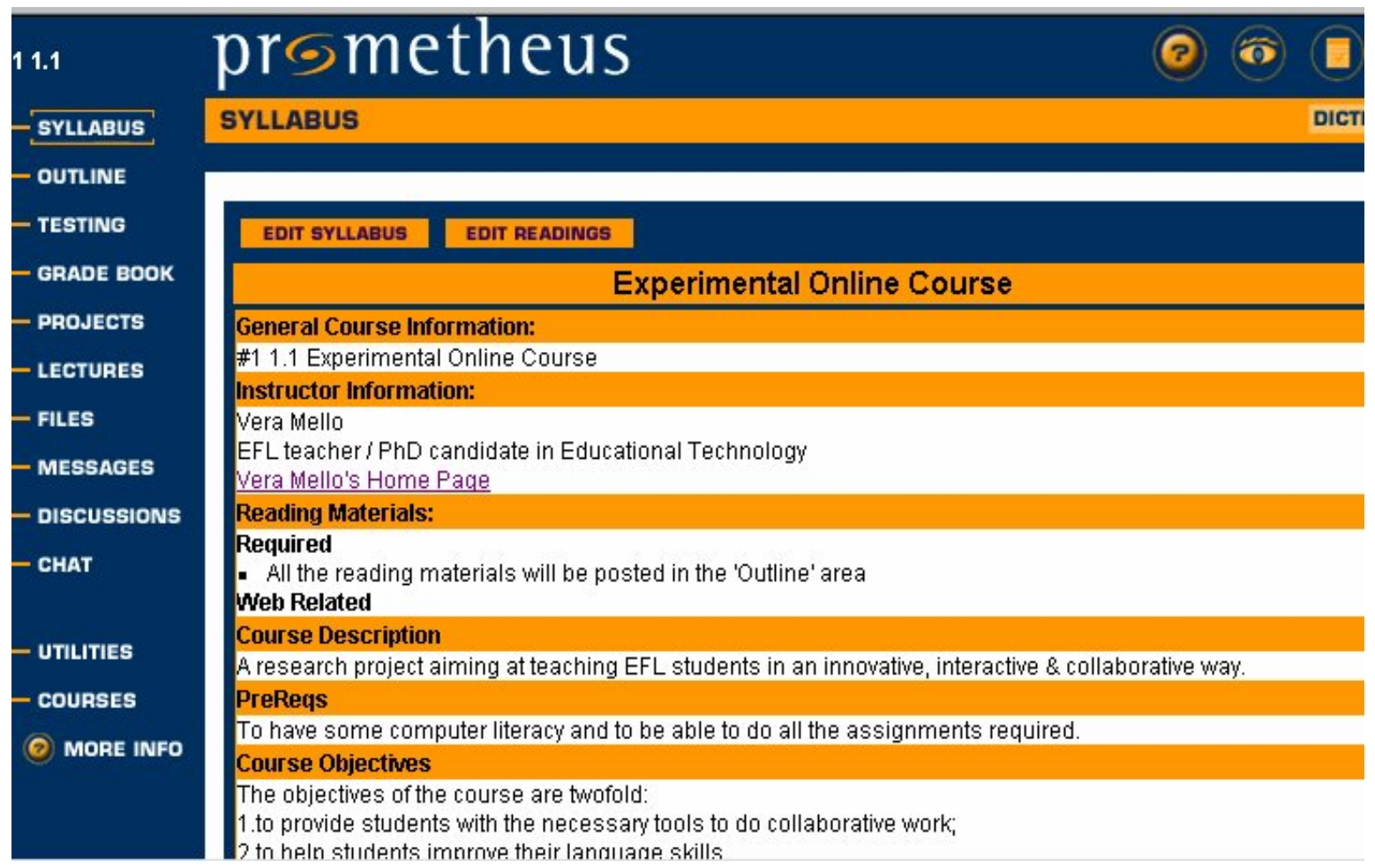

Tela de Planejamento do Curso 


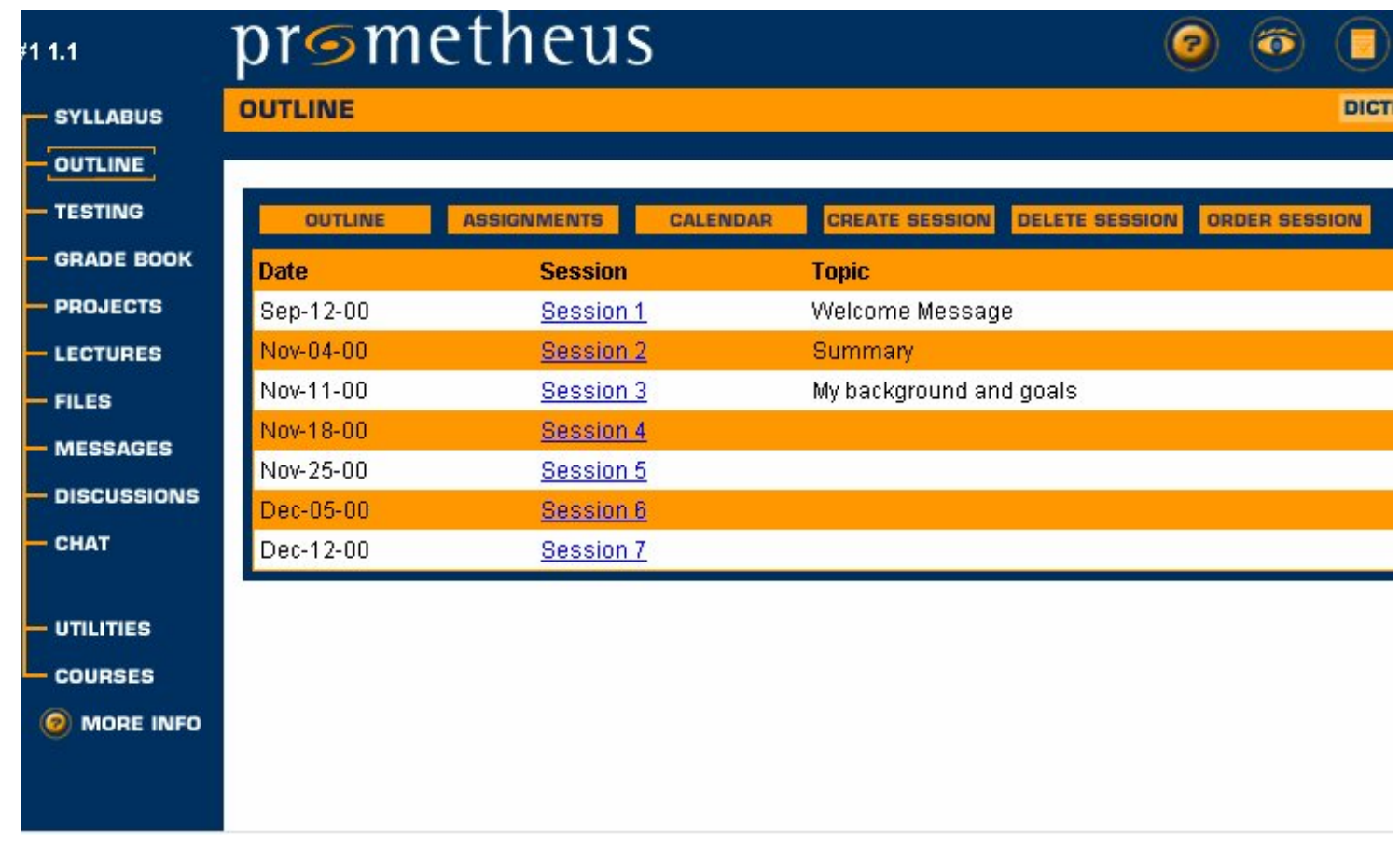

Tela de Sessões e Atividades do Curso

\section{3 - Ferramentas de Colaboração}

Para compartilhamento de idéias e informações, o programa possui recursos, tais como fórum de discussão e ferramentas de transferência e arquivamento de textos e de multimídia. É interessante observar que o professor pode organizar o quadro de arquivos, criando e editando as categorias que achar conveniente, ou apagando aquelas que não são mais necessárias. Basta para isso clicar em Options dentro da área de transferência de arquivos (Files). O programa dispõe também de uma área de criação e edição de projetos individuais ou colaborativos.

Com relação ao fórum de discussão, o programa possibilita ao professor acompanhar o desempenho e participação dos alunos, uma vez que lhe faculta criar fóruns para grupos distintos, ou seja, organizar subgrupos temáticos para discussão de assuntos específicos e ser notificado, através de sua conta de e-mail, quando novas mensagens são colocadas nos fóruns. 
O programa também dispõe de um recurso que permite ao professor, por exemplo, arquivar as mensagens, limitar o número de mensagens enviadas por aluno, e viabilizar ou não o envio de arquivos em anexo para o fórum.

Sob o ponto de vista organizacional, é importante observar que no fórum há a possibilidade de se separar mensagens lidas das não lidas.

\section{4- Ferramentas de Comunicação Síncrona e Assíncrona}

Prometheus possui ferramenta de comunicação assíncrona. O sistema é semelhante ao do correio eletrônico. As mensagens são enviadas automaticamente para o endereço do remetente na Internet. Os destinatários podem ser todos os inscritos no curso, alguns alunos apenas, ou um único integrante do grupo.

O sistema permite também ao professor, através do recurso Announcements, postar avisos importantes para os alunos. Esses avisos são automaticamente salvos pelo programa e disponibilizados, no topo da página inicial do curso, com o tópico e data de envio.

\begin{tabular}{|c|c|c|c|c|}
\hline$x$ General Hetp $=0$ & Seneral Help & & de $\mathrm{N}$ & Mello $=$ \\
\hline $\begin{array}{l}\text { Announcem } \\
\text { DELETE . Welco }\end{array}$ & $\begin{array}{l}\text { ents } \\
\text { me to } 33.3 .1 \text { (18-Jun-00) }\end{array}$ & & & \\
\hline $\begin{array}{l}\text { Course Listi } \\
\text { The courses that }\end{array}$ & $\begin{array}{l}\text { רgs } \\
\text { you have online are listed }\end{array}$ & Course Listings & $x^{k}$ & Kore Infermation \\
\hline your courses, clic & $k$ on the Course Number. & Preferences & $x^{m}$ & Kore Intermstion \\
\hline & & Course Controls & $x^{m}$ & More Intormation \\
\hline & & Archive Library & $x^{m}$ & More Intormstion \\
\hline Course Listi & ngs & & & \\
\hline Course Number & Course Title & & & Hits \\
\hline$\# 1.1$ & BGW Online Course & & 3 & 1040 \\
\hline
\end{tabular}

Tela Inicial com aviso datado de 18/06/00 
Há também no Prometheus uma ferramenta que possibilita a comunicação síncrona: Ichat, porém essa ferramenta possui poucos refinamentos, ou seja, não permite salvar logs (registros) de conversas para posterior análise crítica e re-orientação das atividades, nem dividir o grupo em subgrupos e distribuí-los em outras salas.

\section{5 - Ferramentas de Avaliação}

Prometheus oferece também ferramentas de avaliação de aprendizado. Permite ao instrutor criar testes dos tipos: Verdadeiro/Falso (V/F), Múltipla Escolha, de Respostas Curtas ou Longas. Os testes são feitos on-line e corrigidos automaticamente pelo programa se forem do tipo V/F ou de Múltipla Escolha. Quando o professor cria um teste, pode optar também por estabelecer seu tempo de duração, bem como se as perguntas devem aparecer/vir sempre na mesma sequiência, ou re-ordenadas aleatoriamente pelo próprio programa.

\section{6 - Outras Ferramentas}

O programa possibilita ao professor "customizar" o layout de seu curso e escolher os serviços a serem oferecidos aos alunos. Fazendo uso do Control Panel, o professor faz a seleção das ferramentas que ele julgar relevantes aos objetivos de seu curso, ao perfil e as necessidades dos alunos.

O Student Panel é uma ferramenta que permite ao professor obter informações sobre a última vez que cada aluno se conectou ao programa, número de vezes que o fez e áreas acessadas. Essa ferramenta é também utilizada para incluir ou excluir estudantes.

Outros dois recursos apresentados pelo Prometheus são: Security e Groups. Através do primeiro, de segurança, pode-se identificar ou alterar o nome do curso e sua senha. O segundo, permite a criação ou exclusão de grupos de estudo. 


\begin{tabular}{|c|c|}
\hline Control Panel | Student Panel & Groups \\
\hline \multicolumn{2}{|l|}{ Control Panels } \\
\hline \multicolumn{2}{|l|}{ Use the options below to turn on or off any sections listed. } \\
\hline \multicolumn{2}{|l|}{ Outline: } \\
\hline \multicolumn{2}{|l|}{$\sqrt{ }$ The Course Outline Section is currently Enabled. } \\
\hline \multicolumn{2}{|l|}{ Testing: } \\
\hline \multicolumn{2}{|l|}{$\sqrt{\nabla}$ The Testing Section is currently Enabled. } \\
\hline \multicolumn{2}{|l|}{ Grade Book: } \\
\hline \multicolumn{2}{|l|}{$\sqrt{\nabla}$ The Grade Book Section is currently Enabled. } \\
\hline \multicolumn{2}{|l|}{ Projects: } \\
\hline \multicolumn{2}{|l|}{$\sqrt{ }$ The Projects Section is currently Enabled. } \\
\hline \multicolumn{2}{|l|}{ Lectures: } \\
\hline \multicolumn{2}{|l|}{$\sqrt{ }$ The Lectures Section is currently Enabled. } \\
\hline \multicolumn{2}{|l|}{ Shared Files: } \\
\hline \multicolumn{2}{|l|}{$\sqrt{ }$ The Shared Files Section is currently Enabled. } \\
\hline \multicolumn{2}{|l|}{ Messages: } \\
\hline \multicolumn{2}{|l|}{$\sqrt{V}$ The Messages Section is currently Enabled. } \\
\hline \multicolumn{2}{|l|}{ Discussions: } \\
\hline \multicolumn{2}{|l|}{$\sqrt{\nabla}$ The Discussions Section is currently Enabled. } \\
\hline |Chat: & \\
\hline
\end{tabular}

Tela do Painel de Controle com itens selecionados

\section{7 - Conclusão sobre o programa Prometheus}

Prometheus é um uma plataforma de gerenciamento de curso na Web com vários recursos e ferramentas para a criação de cursos on-line. Não é necessário ao professor ter conhecimentos de qualquer linguagem de programação para trabalhar nesse ambiente virtual.

\section{2 - Blackboard}

É de fácil utilização e apresenta interface amigável e flexível, possibilitando, de certa forma, a "customização" de seu layout padrão. O programa também possibilita ao professor selecionar ferramentas (de comunicação, de colaboração, etc), dependendo de seu interesse, da dinâmica do curso e das atividades a serem ministradas.

Blackboard apresenta ferramentas que permitem ao professor acompanhar o desenvolvimento do aprendizado dos alunos e de sua participação no curso; outras que lhe 
permite a criação de grupos temáticos, com possibilidade de uso de áreas privadas de envio de arquivos, área de elaboração de projetos colaborativos e fóruns de discussão.

Oferece áreas de disponibilização de conteúdos da disciplina: avisos, informações sobre o curso e instrutor(es) do mesmo, materiais relevantes, calendário, tarefas e links externos.

Através de um painel de controle, o professor gerencia o curso e o adapta a seus propósitos específicos.

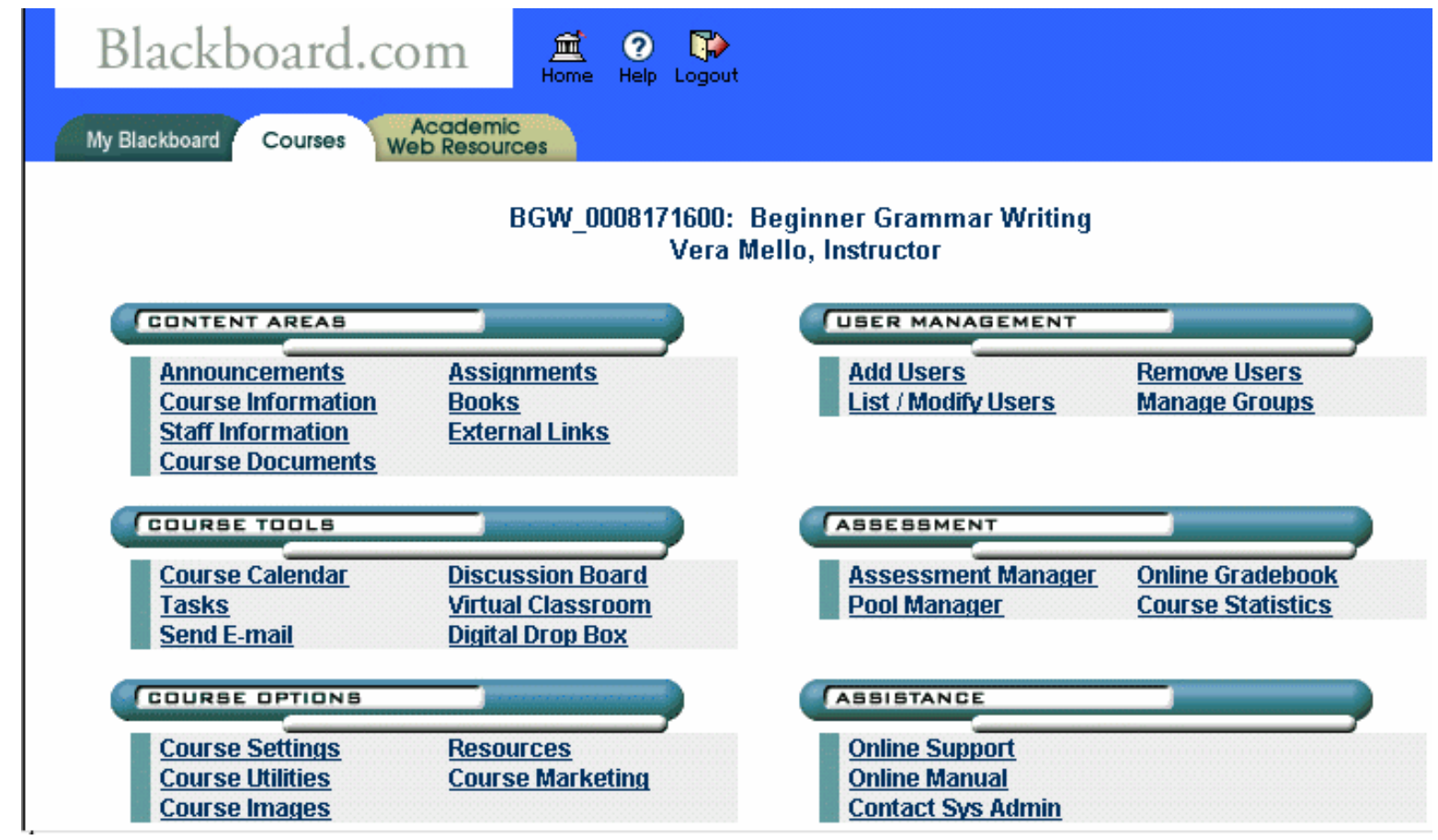

Tela Painel de Controle de Curso

A navegação no Blackboard está praticamente toda definida. Por uma barra de comandos à esquerda, o professor e /ou os alunos têm, à sua disposição, as ferramentas do curso.

O acesso ao programa se faz através de user name e senha individual. A partir do endereço: http://coursesites.blackboard.com, tem-se acesso à página onde se pode criar uma conta. Basta então clicar em Create Account e fornecer os seguintes dados: nome, sobrenome, email, user name e uma senha que deve ser confirmada. 
O programa cria então automaticamente uma página inicial para cada usuário, que pode, ou não, personalizá-la com conteúdo do(s) curso(s) em que está inscrito; e no caso do professor, os cursos que ministra. Vale ressaltar, entretanto, que o programa, ao criar a página inicial, a personaliza com o nome do usuário e uma saudação Welcome! Nome do usuário.

Para a inscrição em um curso, o aluno só poderá fazê-lo sozinho se este for aberto a visitantes. Caso contrário, o professor é que através do nome e sobrenome do aluno, o inscreve no curso, restringindo desta forma acesso a visitantes.

\section{1 - Ferramentas de Colaboração}

Para compartilhamento de idéias e informações, o programa possui recursos tais como: fórum de discussão, Digital Drop Box - ferramenta para a transferência e envio de arquivos texto e de multimídia -, e ferramenta para criação de grupos temáticos.

Com relação ao fórum de discussão, o programa possibilita arquivar mensagens, marcar aquelas que não foram lidas, coletar mensagens de interesse, selecioná-las por assunto, autor ou data. Inclui também um dispositivo de busca de mensagens.

A ferramenta (Group) faculta ao professor a criação de grupos distintos, ou seja, a organização de subgrupos para discussão de assuntos específicos. Uma vez criadas as áreas de trabalhos de grupos, os alunos passam a ter acesso a fóruns de discussão e chat privados. Podem também trocar arquivos entre si, bem como mensagens que podem ser enviadas a partir de um sistema interno de $e$-mail.

\section{2 - Ferramentas de comunicação}

Blackboard possui ferramentas de comunicação assíncrona. Uma delas utiliza um sistema semelhante ao do correio eletrônico. As mensagens são enviadas automaticamente para o endereço do remetente na Internet. Os destinatários podem ser todos os inscritos no curso, alguns alunos apenas, ou um único integrante do grupo. Caso o curso seja ministrado em conjunto com outros professores ou assistentes, mensagens podem ser enviadas exclusivamente para eles através do programa de e-mail. 
Outro recurso de comunicação assíncrona é o Announcements (quadro de avisos) que permite ao professor postar recados importantes para os alunos. Esses recados são automaticamente gerados na página inicial de cada usuário - caso este tenha personalizado essa página. Os recados também podem ser acessados através do botão do menu lateral, na página do curso.

Há também no Blackboard uma ferramenta denominada Virtual Classroom que possibilita a comunicação síncrona. Essa ferramenta possui características interessantes, a saber:

- Whiteboard - recurso que possibilita o compartilhamento de gráficos, desenhos e anotações.

- Navigation - recurso que possibilita a navegação conjunta em tempo real em Websites.

- Lessons - recurso que possibilita a 'navegação' através de slides préselecionados.

Essa ferramenta, apresentada pelo Blackboard, constitui um grande diferencial em relação, por exemplo, ao Prometheus, pois oferece subsídios ao professor para a criação de um curso mais interativo, se empregada de forma eficaz e com objetivos didáticos pré-estabelecidos. Além disso, a ferramenta mostra-se também útil, sob o ponto de vista operacional e organizacional, uma vez que possibilita ao educador 'determinar' quais os recursos que devem ou não ser compartilhados por todos e, em se tratando de atividade de chat, quem terá a palavra e quando. Os logs das conversas são automaticamente salvos pelo programa e arquivados por datas, o que facilita a busca por 'conversas' nele realizadas. Basta para isso 'navegar' pelos arquivos das sessões realizadas. 


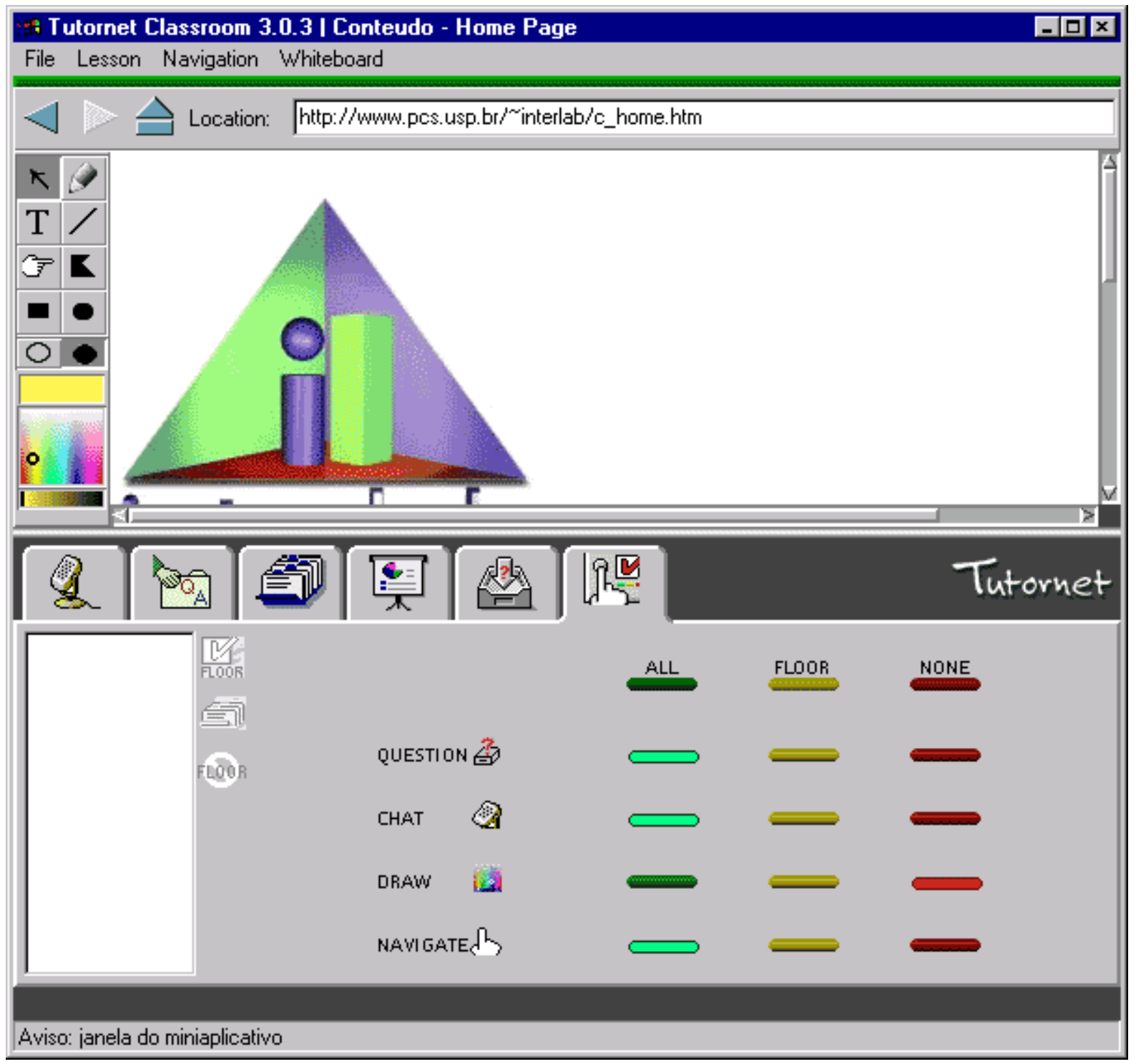

Tela de exemplificação da ferramenta de chat

\section{3 - Outras ferramentas}

Blackboard oferece ferramentas que possibilitam ao professor criar testes e exames e determinar o tipo de teste (múltipla escolha, verdadeiro ou falso, complete com palavras, entre outros), o tempo que o aluno deve levar para finalizar a tarefa, número de tentativas e a avaliação. 
Dispõe também de um recurso que grava automaticamente os acessos feitos pelos alunos ao Blackboard, o que facilita ao professor avaliar o interesse e participação de cada um deles.

Há ainda os recursos de segurança, que permitem a inscrição ou exclusão de alunos por parte do professor.

Para tornar o ensino-aprendizagem no ambiente da Web 'menos virtual' e 'mais prático', Blackboard apresenta ainda as seguintes ferramentas:

- Roster através do qual se gera um mecanismo de busca de alunos registrados no curso.

- Página pessoal dos alunos (homepage), onde cada um pode colocar sua foto, links de interesse e dados pessoais.

- Electronic Blackboard, um bloco de notas, que ao ser acionado, abre uma pequena janela, como frame onde o aluno pode gravar anotações pessoais sobre o curso, tarefas a serem realizadas, etc.

\section{4 - Conclusões sobre o Programa}

Blackboard apresenta basicamente as mesmas ferramentas de gerenciamento e administração de cursos na Web oferecidas pelo Prometheus. O grande diferencial encontrado está na ferramenta de chat do Blackboard, que apresenta vários recursos fundamentais para compartilhamento de idéias, troca de informações e experiências em tempo real.

Além dessa vantagem, o programa também dispõe de área para criação de páginas pessoais dos alunos, o que é fator de aproximação e socialização dos membros do grupo. 


\section{5 - Quadro das principais semelhanças e diferenças entre Prometheus e Blackboard}

\begin{tabular}{|c|c|c|}
\hline Análise/Programas & Prometheus & Blackboard \\
\hline Desenvolvido por: & George Washington University & Blackboard, Inc. \\
\hline Plataforma & Arquitetura de código aberto ${ }^{6}$ & Arquitetura proprietária $^{7}$ \\
\hline Interface & $\begin{array}{l}\text { Amigável. } \\
\text { Não requer conhecimento de } \\
\text { linguagem de programação }\end{array}$ & $\begin{array}{l}\text { Amigável. } \\
\text { Não requer conhecimento } \\
\text { de linguagem de programação. }\end{array}$ \\
\hline Navegação & $\begin{array}{l}\text { Definida por barra de ferramentas } \\
\text { localizadas à esquerda da página. }\end{array}$ & $\begin{array}{l}\text { Definida por barra de } \\
\text { ferramentas localizadas à } \\
\text { esquerda da página. }\end{array}$ \\
\hline Tutorial On-line & Sim & Sim \\
\hline $\begin{array}{l}\text { Dicionário } \quad \mathrm{e} \\
\text { Thesaurus }\end{array}$ & Sim & Não \\
\hline $\begin{array}{ll}\text { Ferramentas } & \text { de } \\
\text { administração } & \end{array}$ & Sim & Sim \\
\hline $\begin{array}{l}\text { Ferramentas para criação de } \\
\text { ambiente de colaboração }\end{array}$ & Sim & Sim \\
\hline $\begin{array}{l}\text { Ferramentas de manutenção, } \\
\text { gerenciamento, envio e } \\
\text { armazenagem de conteúdos }\end{array}$ & Sim & Sim \\
\hline $\begin{array}{l}\text { Ferramentas de avaliação e } \\
\text { gerenciamento de alunos, in- } \\
\text { cluindo relatórios e estatísticas }\end{array}$ & Sim & Sim \\
\hline $\begin{array}{l}\text { Ferramenta para criação de } \\
\text { homepage }\end{array}$ & Não & Sim \\
\hline $\begin{array}{l}\text { Ferramentas de comunicação } \\
\text { síncrona e assíncrona }\end{array}$ & Sim & Sim \\
\hline Ferramenta de colaboração & Sim & Sim \\
\hline
\end{tabular}

\footnotetext{
6 Arquitetura onde os códigos podem ser visualizados, usados ou alterados pelo programador, sem necessidade de consulta ao autor da programação.

7 Também denominada "arquitetura proprietária", diz respeito a um programa que não é gratuito. Seu uso, redistribuição ou modificação é proibido ou exige autorização do autor.
} 
O quadro apresentado anteriormente mostra que não há grandes diferenças entre os ambientes: Prometheus e Blackboard. É importante mencionar que Prometheus foi adquirido pela Blackboard, Inc., em janeiro de 2002. 


\section{A pêndiœ L}

\section{Tecnologia D igital: A mbiente V irtual - $\mathbf{M O O}$}

No final de agosto de 1999, participando de uma palestra, intitulada "How computers can help education meet competing pedagogical and cognitive demands", veiculada pelo Departamento de Línguas Modernas da Faculdade de Filosofia, Ciências e Letras da USP, tive a oportunidade de ouvir o conferencista Martin Rosenberg ${ }^{8}$ falar sobre MOOs e sua aplicação na educação, principalmente como instrumento para elaboração de projetos interculturais colaborativos.

Em busca de maior aprofundamento sobre o que é MOO, recorri primeiramente à literatura especializada sobre esse tema. A literatura sobre MOOs é bastante vasta. Vários são os autores que estudam a implementação dessa tecnologia digital na educação, dentre eles: Fanderclai (1995 \& 1996) e Nolan (1995). Outros como Falsetti (1995), Pinto (1995) e Turbee (1996) estudam o uso de MOO para o ensino de línguas. Desses três últimos, destaca-se o trabalho de Pinto (1995), onde o autor mostra os resultados de um estudo etnográfico, realizado com um grupo de alunos de inglês como segunda língua no SchMOOze ${ }^{9}$.

Com o intuito de pesquisar o que era MOO, sua arquitetura e funcionalidade, inscrevi-me como usuária no SchMOOze (acessado via telnet através do endereço: schmooze.hunter.cuny.edu port 8888) e no DUMain (outro MOO educacional, acessado via www.du.org port 8888). Com isso, pude verificar algumas vantagens e limitações do programa e avaliar o potencial desse tipo de ambiente de aprendizagem colaborativa para o ensino.

\footnotetext{
${ }^{8}$ Professor assistente de comunicação da Universidade de Kettering.

${ }^{9}$ MOO educacional, criado em 1994 por Julie Falsetti, com o propósito de ser um local onde alunos e professores de inglês se encontram para praticar a língua inglesa e trocar experiências de cunho intercultural.
} 


\section{1- Características G erais do $\mathbf{M O O}$}

MOO é um tipo de MUD ${ }^{10}$ - Multi-User Domain, Object Oriented. O MOO é escrito em uma linguagem denominada MOOCode que é uma combinação de $\mathrm{C}++{ }^{11} \mathrm{e}$ LISP $^{12}$.

É um programa de interface textual que permite a multi-usuários, conectados à Internet, ter acesso a um ambiente virtual. MOO diferencia-se de outros programas de chat, pois permite aos usuários não só se comunicarem entre si, em tempo real, o que é o caso do chat, mas também manipularem e interagirem com os objetos nele contidos. Utiliza-se a metáfora dos objetos, para todas as pessoas e coisas descritas no MOO.

Segundo McCleary (1996) "a existência da metáfora dos espaços e dos objetos dos MUDS fornece um enriquecimento do meio, por criar canais virtuais 'visuais', 'tácteis' e 'sonoros'”, (p.23).

A possibilidade de se criar mentalmente um espaço imaginário ao "navegar" pelo MOO é o que estabelece o potencial desse ambiente digital.

Todo MOO é temático e o SchMOOze tem como tema um campus virtual e tudo o que há nele: salas de aula e de conferência, dormitórios, biblioteca, diretório acadêmico (com salão de jogos didáticos, bar), etc.

A linguagem usada nas descrições dos ambientes e objetos no SchMOOze é simples e de fácil compreensão para o aluno de inglês (não principiante). Os textos são compostos, em sua grande maioria, por períodos simples, porém a linguagem é rica em imagens descritivas, como no exemplo de descrição do hall da biblioteca (library lobby):

\footnotetext{
${ }^{10}$ Ambiente virtual onde os jogadores assumem identidades fictícias e seguem uma série de regras que guiam os jogos de aventura.

${ }^{11}$ Linguagem de computador baseada em C que usa os princípios de programação orientada a objeto.

${ }^{12}$ Linguagem de programação. É um acrônimo para LIST Processing.
} 


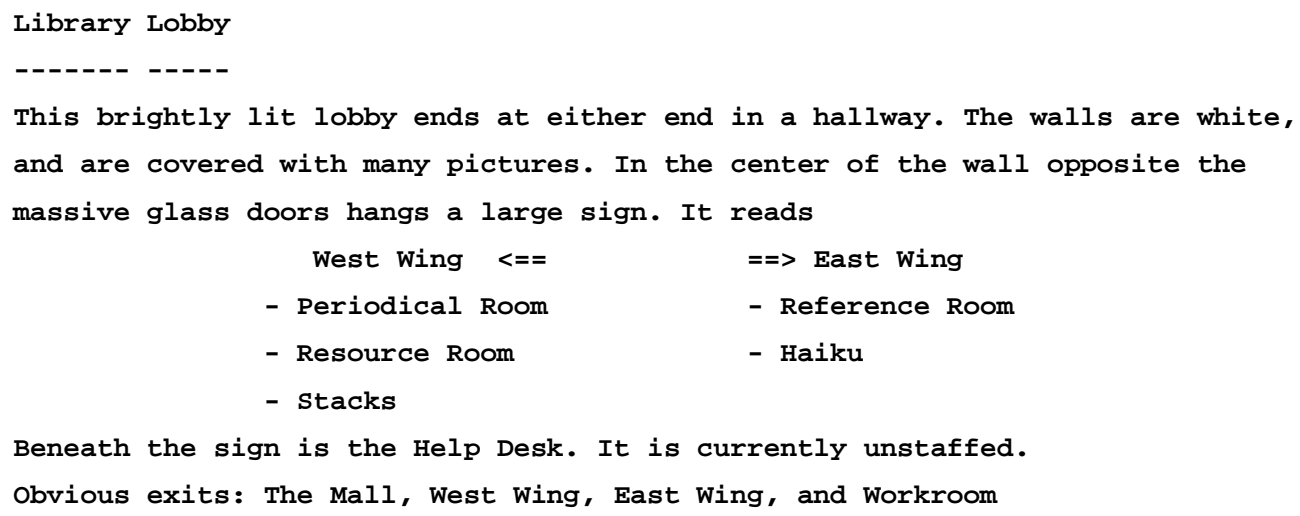

Embora a palavra seja a essência no MOO, os desenhos gráficos acrescentam realismo a esse ambiente virtual. As imagens são produzidas por meio de simples arquivos de texto ASCII ${ }^{13}$ formatados para criar um desenho. Digitando-se o comando look portrait, vêse o 'retrato' de Mehitabel, a fundadora do SchMOOze.

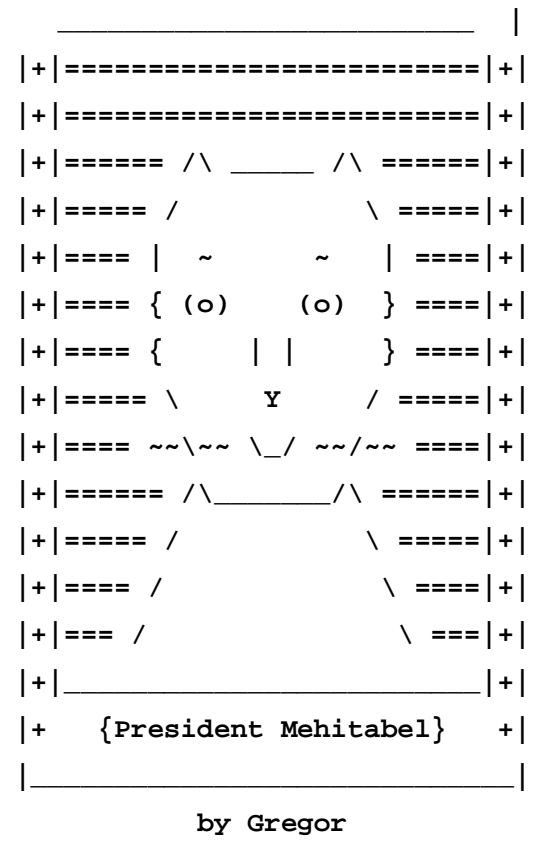

Ao iniciar uma sessão no MOO, o usuário conecta-se, primeiramente, com o servidor do MOO.

${ }^{13}$ (Acrônimo para American Standard Code for Information Interchange) - é um código que designa um número para cada letra do teclado. Os textos em ASCII não têm uma formatação especial podendo, portanto, serem trocados e lidos pela maioria dos sistemas computacionais. 
É recomendada a instalação de um cliente (por exemplo, Pueblo), programa que facilita a comunicação no MOO. O Pueblo apresenta interface simples, com duas janelas: uma pequena - onde se digita os comandos e as mensagens que podem ser editadas antes de serem enviadas -, e uma janela grande - onde se vêem as mensagens dos outros usuários e as respostas aos comandos dados.

Uma vez conectado, o usuário digita o comando: connect guest [ENTER]. É pedido a ele, então, para escolher um nome e fazer uma pequena descrição de si mesmo. Se a intenção for usar o MOO regularmente, aconselha-se solicitar - ao administrador do MOO -, um character name (um nome pelo qual deseja ser conhecido no MOO) e uma senha. Evita-se, com isso, ter que escolher um nome e fazer uma descrição de si mesmo, todas as vezes que se conectar. O sistema solicita também ao usuário que passar a freqüentar o MOO identificação quanto ao sexo.

A locomoção dentro do MOO se dá através de saídas (exits) pré-estabelecidas pelo sistema.

\section{2 - Recursos de Comunicacãa Síncrona}

A comunicação no MOO é essencialmente síncrona. Os usuários podem interagir no MOO com outros usuários e com os objetos nele existentes. Isto é possível porque no servidor, ou seja, no computador onde o programa MOO roda estão armazenados, em um banco de dados, todas as descrições dos objetos do MOO.

Através de comandos tais como look, examine, play, entre tantos outros, os usuários interagem com os objetos programados. Tudo no MOO (inclusive os usuários, em inglês, characters) apresentam uma descrição e um número (que lhes serve de identificação) e é considerado um objeto, conforme mencionado anteriormente. Caso o usuário digite o comando look Veruska (meu apelido no SchMOOze) ou look \#1607(meu número) verá em sua tela a seguinte descrição que fiz de meu personagem (character/persona):

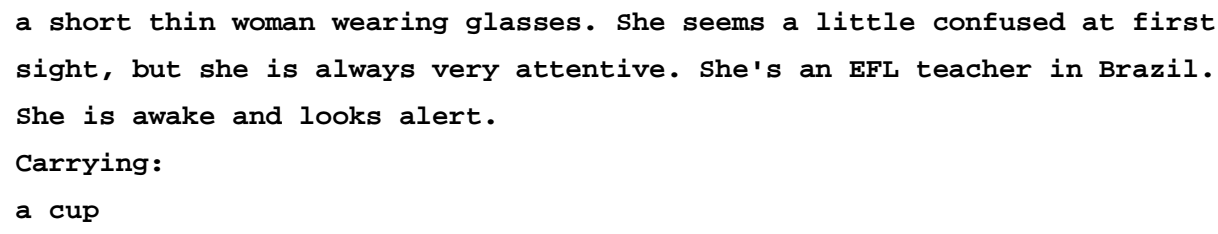


As conversas no MOO são distribuídas pelos vários ambientes onde os usuários se encontram. É comum ao entrar no MOO, o usuário digitar o comando @ who para verificar quem está conectado, tempo de conexão, tempo de atividade ou inatividade (ou seja, quando tocou o teclado pela última vez) e local onde se encontra. Por exemplo:

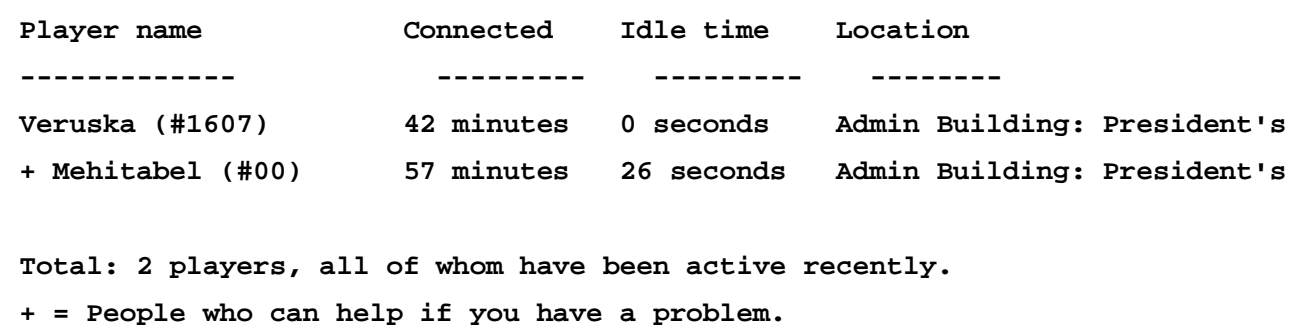

Entretanto, uma vez conectado, o usuário passa a ver em sua tela quem entra e sai do programa. A mensagem de conexão ou desconexão e número de usuários on-line são automaticamente enviados pelo sistema, como pode ser verificado na linha 3 do exemplo a seguir:

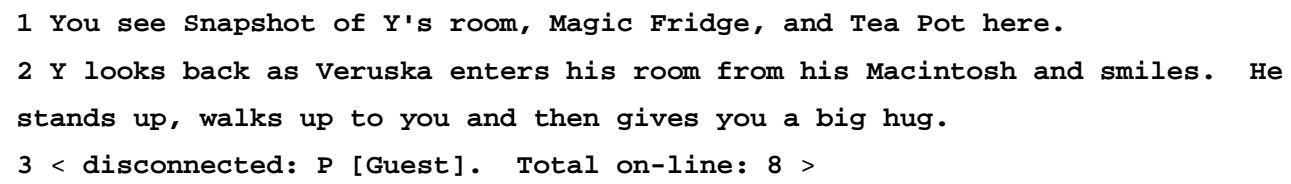

Estando os usuários em um mesmo ambiente podem interagir uns com os outros, 'ouvindo' e participando de conversas. Três são as formas básicas de comunicação: say, emote e whisper.

Através do comando say <mensagem > ou "<mensagem>, o programa gera automaticamente para o remetente sentenças na segunda pessoa do singular (you), e para o(s) outro(s) usuário(s), sentenças na terceira pessoa do singular precedidas do nome de quem enviou. Por exemplo, ao se digitar:

say нi. (ou "ні.) [ENTER]

Aparece na tela de quem mandou a mensagem:

You say, "Hi".

E na tela do(s) outro(s) usuário(s):

Veruska says, "Hi" 
Em conversação entre mais de dois usuários, digita-se to <nome do colocutor>, antes da mensagem. Tem-se assim a identificação do destinatário, como nas linhas 5, 6, 8, 9, 11, do exemplo a seguir, extraído de parte de uma conversa da qual participei, no dia 13 de novembro de 1999, no DUMain, com Bernardo ${ }^{14}$.

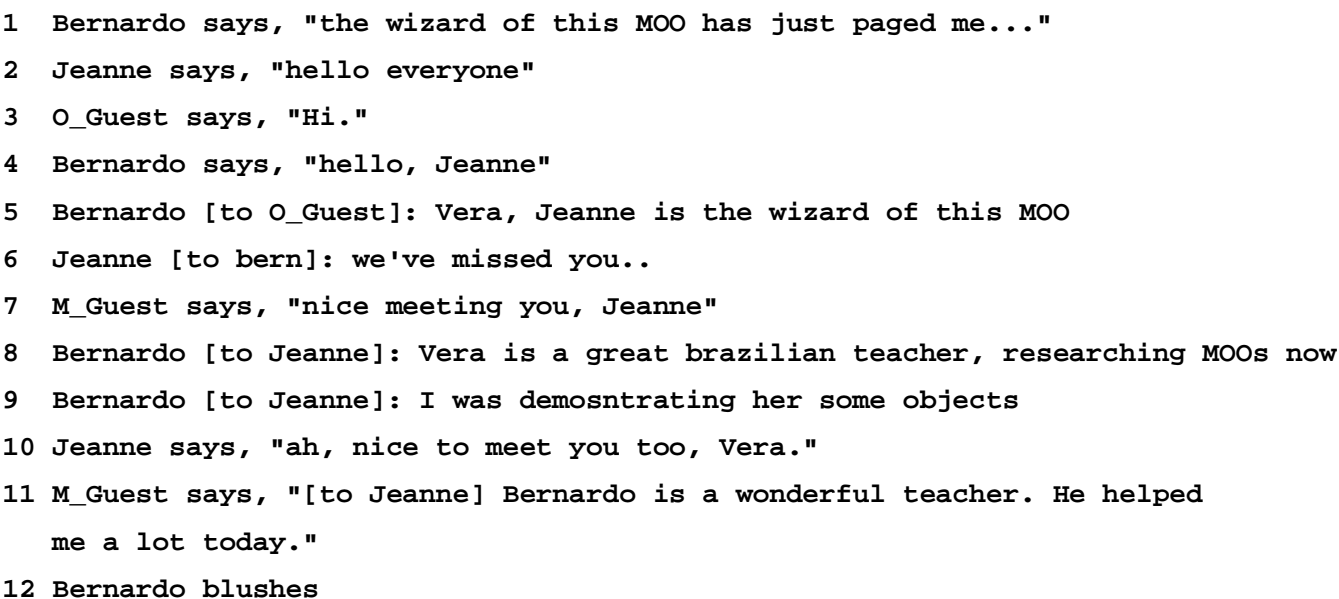

Emote é o mecanismo utilizado para a simulação de ações e de estados de espírito em um meio totalmente textual. Para representar o não-verbal como, por exemplo: wave, nod, grin (em português: acenar, assentir com a cabeça e mostrar satisfação, respectivamente), usa-se o comando dois pontos (:) seguido do verbo na terceira pessoa do singular com ou sem complemento.

Digitando-se :dances around like a fool [ENTER], todos os que estiverem no mesmo local vêem na tela: Veruska dances around like a fool.

O sistema gera automaticamente o nome do remetente e o antepõe ao verbo.

Os chamados emoticons, ou smileys ${ }^{15}$ (que representam expressões faciais, quando olhados com a cabeça inclinada para a esquerda) são também utilizados para indicar estados de espírito e atenuar problemas oriundos da ausência de informações paralingüísticas em um meio escrito. O smiley :-) do final da oração, a seguir, indica que o usuário está "feliz".

Veruska thinks you are doing a good job. :)

\footnotetext{
${ }^{14}$ Amigo argentino, veterano no MOO, que me auxiliou a entender e utilizar esse ambiente virtual.

${ }^{15}$ Representam expressões faciais, quando olhados com a cabeça inclinada para a esquerda. São utilizados para indicar estados de espírito e atenuar problemas oriundos da ausência de informação paralinguística em um meio escrito.
} 
Para se comunicar, em particular, com um outro usuário que se encontra no mesmo local público, utiliza-se o comando whisper " $\langle$ mensagem $\rangle$ ” to $\langle$ destinatário $\rangle$. Apenas esse usuário "ouvirá" a mensagem.

Além dessas formas de comunicação existentes, há outras duas, que são utilizadas para conversas com usuários que se encontram em diferentes locais no MOO. São elas: page e a utilização de um canal público.

Assim, quando se digita page meh hi, vê-se na tela a seguinte mensagem: your message has been transmitted across the matrix and is now in the paws of the cat. $O$ destinatário, por sua vez, recebe a mensagem que lhe foi enviada.

Não há necessidade de se deslocar de onde o usuário se encontra para responder a esse tipo de mensagem, chamada em inglês de paging message. Pode-se simplesmente mandar um outro page para quem a remeteu. Paging messages são particulares. Este recurso é utilizado para conversas curtas, ou simplesmente para dizer "alô". Assim como na vida real, também na virtual, existem convenções sociais (regras de etiqueta) que devem ser seguidas. Se a intenção for "bater papo" é de bom tom usar, primeiramente, o comando knock <nome do usuário> para se certificar da disponibilidade do interlocutor para a conversa. Caso este esteja disponível, fará um convite para que o primeiro se junte a ele. Através do comando @ join <nome do outro colocutor> será imediatamente "transportado" para o local onde o colocutor se encontra.

Conforme mencionado anteriormente, conversas também podem ocorrer através de canais. No caso do SchMOOze, faz-se uso de um canal público. Para poder se comunicar através dele, cada usuário deve primeiramente adicionar essa propriedade a sua persona. A partir disso, independentemente do ambiente em que esteja, "ouvirá" a conversa e tomará parte nela juntamente com os demais usuários que estiverem ligados ao canal. Este mecanismo assemelha-se ao page, no que tange a possibilidade de se manter conversas entre locutores que se encontram em locais distintos. Diferencia-se, entretanto, daquela modalidade quanto ao número de indivíduos que passam a receber e transmitir mensagens. No caso do page é um a um, e no caso do canal entre vários interlocutores. 


\section{3- Recursos de Comunicação A ssíncrona}

Há também nos MOOs ferramentas que possibilitam a comunicação assíncrona. Uma delas é o sistema de MOOmail. Esse sistema é semelhante ao do correio eletrônico e possibilita enviar, responder e mandar adiante (forward) mensagens dentro do MOO para um ou vários destinatários.

A correspondência no MOO consta basicamente de três partes: um cabeçalho contendo informações sobre hora e data do envio, identificação do usuário (nome e número usado no MOO), identificação do destinatário (nome e número) e o assunto -; a mensagem propriamente dita, e a identificação do remetente (assinatura). Um exemplo é a mensagem 2, a seguir, que me foi enviada no dia 10 de novembro de 1999.

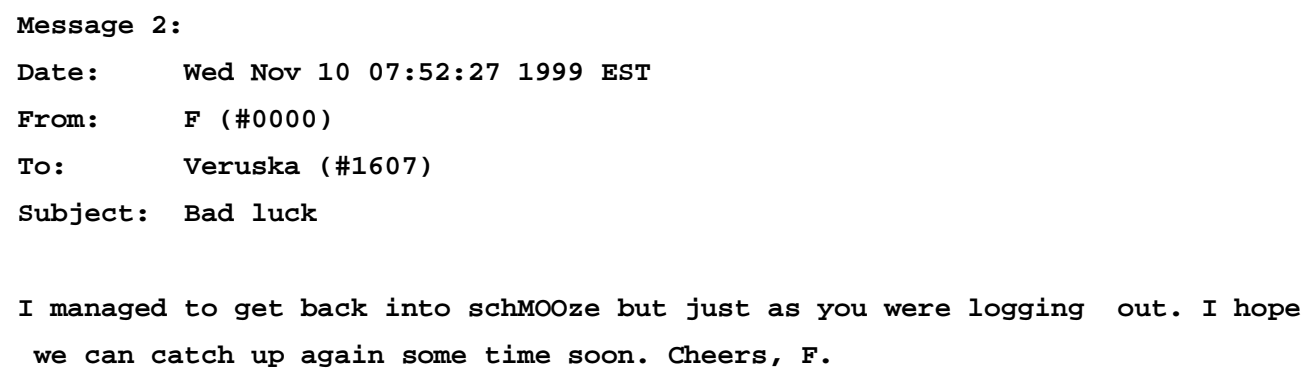

A existência de novas mensagens é automaticamente anunciada ao usuário, quando este inicia a sessão no MOO. Após lidas, as mensagens só são recuperadas através do comando @ read <número da mensagem>. Fica a critério do usuário reler, manter ou excluir as mensagens. Caso opte por mantê-las, elas ficam arquivadas, no banco de dados do MOO, por ordem cronológica de envio e com identificação do remetente e o assunto. A seguir, um exemplo recuperado de meu arquivo no MOOmail.

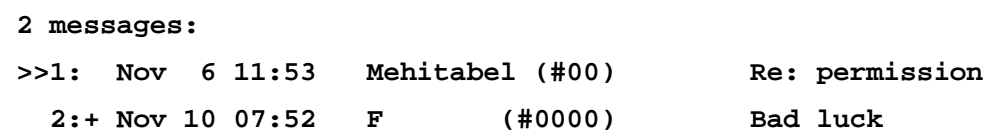

O sistema permite também o envio automático de mensagens para o endereço eletrônico do remetente na Internet. Basta, para isso, utilizar o comando @ netforward e o número da mensagem que se quer enviar. 
A lista de discussão é outra modalidade assíncrona encontrada. No SchMOOze, há fóruns públicos e particulares. Esses últimos só permitem a participação de pessoas envolvidas na administração e organização do MOO.

Após inscrever-se em uma ou mais listas, passa-se a ter o direito de ler e enviar mensagens. Todas as mensagens enviadas para a lista são armazenadas no banco de dados e disponibilizadas aos usuários inscritos, quando por eles solicitadas, por meio de comando especial. O sistema notifica a existência de novas mensagens na lista, quando o usuário se conecta ao MOO.

As mensagens são catalogadas por ordem numérica, de acordo com a data e horário em que foram enviadas para a lista. Identificam também o nome e número do usuário e o tópico. As listas de discussão no SchMOOze não são moderadas. Neste tipo de lista não há um moderador que recebe e seleciona as mensagens que devem ser enviadas para os assinantes da lista. Todas as mensagens, sem exceção, são enviadas aos que estão inscritos na lista.

\section{4- 0 utros Recursos}

No MOO há também outras ferramentas, que embora possam ser utilizadas por um único usuário, são apropriadas para apresentações, conferências e aprendizagem colaborativa. Dentre elas, temos: a lousa (blackboard), a TV/VCR e o projetor.

Na lousa pode-se escrever e editar mensagens, perguntas, notas curtas, etc. É um arquivo texto que pode ser apagado quando não for mais necessário.

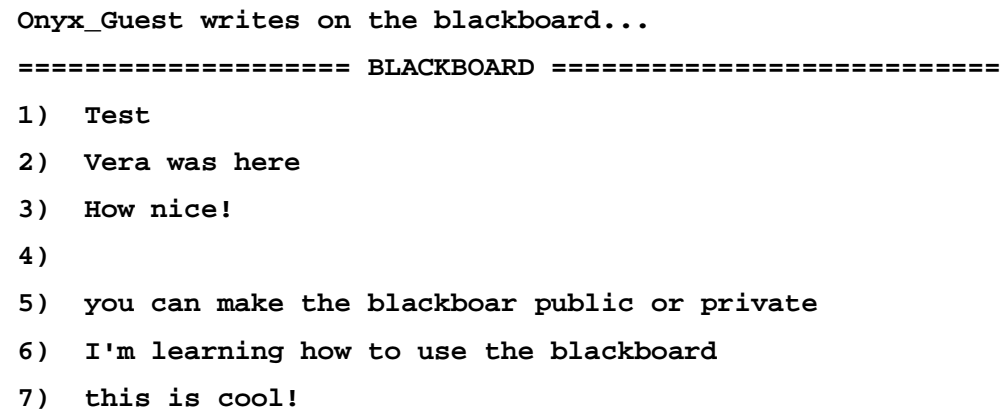


O projetor é utilizado na apresentação de material previamente preparado, com uma ou mais linhas de texto, em forma de slides, como em:

O_Guest shows slide \#1.

* I pulled my hair out trying to log onto one of them...

* I am beginning to think all computers hate me! I had a problem logging onto the Moos...

* I couldn't get into a MOo, and nearly drove myself crazy trying to do so...

* I was disconnected, twice, just as I though I arrived somewhere important...

* The Moo disconnected me because I was 'too restless to meditate'...

A TV/VCR é utilizada para seqüências programadas. Em geral, são tutoriais sincrônicos interativos que permitem ao usuário controlá-los - parando, repetindo ou iniciando, etc. -, o processo, quantas vezes desejar.

Links para materiais de referência, pesquisa, e páginas na Web, podem ser acessados através do próprio programa MOO, como exemplificado através do link que criei em meu ‘dormitório’ virtual (home) no SchMOOze:

\begin{tabular}{l}
\hline home' \\
You're already home! \\
look here \\
Veruska's Room \\
You see a cozy room decorated with brand \\
new furniture. On the left corner \\
there's a PC on top of a pretty wooden \\
table. Your eyes are caught by blue \\
cushions on the floor. You feel like \\
resting a little here. Veruska looks at \\
you and invites you to come in. She wants \\
to show you her homepage at \\
http: / www.geocities. com/Athens/Olympus/4038/ $/$ \\
She has been working on it and \\
would like to know your opinion about it. \\
obvious exits: out \\
I
\end{tabular}




\title{
1.5- V antagens e limitạ̧oes do M 00
}

A partir da análise feita no SchMOOze e no DuMain, pude constatar vantagens e limitações do programa MOO.

Como vantagem é importante mencionar que o programa incorpora, em sua arquitetura, ferramentas síncronas e assíncronas, o que facilita a comunicação, participação interativa e colaboração entre os usuários. Outro recurso que me parece ser interessante, em termos educacionais, é o de possibilitar ao usuário criar sua própria identidade, ambiente e objetos virtuais dentro do MOO.

Fanderclai (1995) ${ }^{16}$ também aponta para a importância desse recurso para os alunos ao afirmar que:

\begin{abstract}
"Eles podem construir seu próprio espaço e experimentar uma nova persona, novas formas de pensar, novas formas de interagir. Teriam respostas imediatas a suas idéias e aos objetos texto que criaram, experimentando dinamicamente os efeitos que suas palavras criam nos outros."
\end{abstract}

Incentiva-se, desta forma, principalmente, o desenvolvimento de competências lingüísticas e de criatividade dos alunos.

O grande problema que observei com relação ao MOO, como usuária, é sua complexidade, ou seja, a dificuldade que se tem de familiarização com esse tipo de espaço virtual e com o domínio dos comandos necessários para sua eficaz utilização. A curva de aprendizagem do manuseio do programa é difícil e, muitas vezes, até frustrante, o que, a meu ver, compromete seu uso em situações de ensino na modalidade totalmente on-line.

\footnotetext{
${ }^{16}$ No original: “[...] They could construct their own spaces and try on new personae, new ways of thinking, new ways of interacting. They would get immediate responses to their ideas and to the text objects they created experiencing dynamically the effects their words have on others." T. L. FANDERCLAI. "MUDS in education: new environments, new pedagogies". Computer-Mediated Communication Magazine, v. 2, n.1, Jan. 1995, p.8.
} 


\section{A utorização de U so}

To: Vera Mello <vcqm@xxxxxxxxxx>

Subject: Re: permission

Date: Sat, 17 Aug 2002 00:42:25 -0400 (EDT)

From: Julie Falsetti<jfalsett@xxxxxxxxxxxx>

No problem. Mehitabel would be honored to have her picture in your dissertation.

Quoting Vera Mello <vcqm@xxxxxxxxxx>:

$>$ Hi Julie,

$>$ I don't know if you still remember me: veruska at SchMOOze. I'm writing

$>$ my dissertation and will include as appendix a report on MOO. So, I'd like

$>$ to ask your permission to insert Mehitabel's pic in the report. Thanks a

$>$ lot.

$>$

$>$ Best,

$>$ Vera

$>$

$>$ Vera Mello 